\title{
FILYÓ JANKA
}

\author{
Kis- és középvállalkozások \\ számviteli beszámolási rendszerének elemzése \\ a szabályozás és az alkalmazott gyakorlat \\ tükrében
}




\section{PÉNZÜGYI SZÁMVITEL TANSZÉK}

Témavezető:

Dr. Lukács János, CSc

Copyright @ F Filyó Janka, 2017.

Minden jog fenntartva! 


\section{BUDAPESTI CORVINUS EGYETEM}

Gazdálkodástani Doktori Iskola

\section{Kis- és középvállalkozások számviteli beszámolási rendszerének elemzése a szabályozás és az alkalmazott gyakorlat tükrében}

Doktori értekezés

\section{Filyó Janka}

Budapest, 2017. 


\section{TARTALOMJEGYZÉK}

TARTALOMJEGYZÉK 5

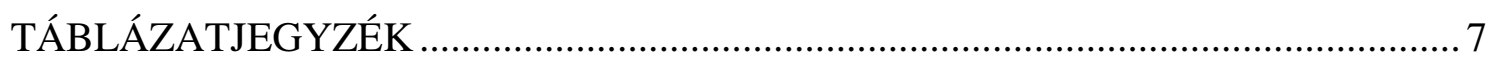

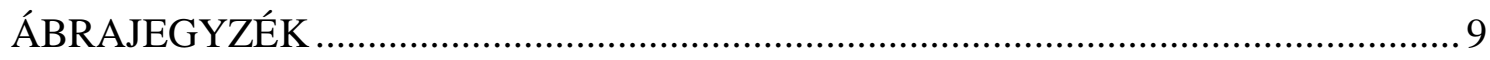

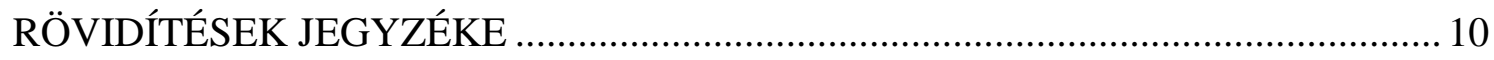

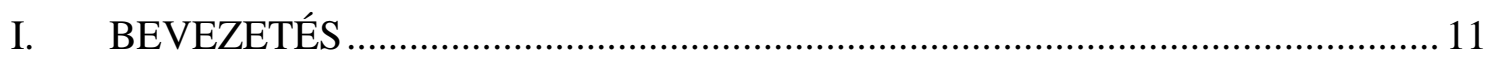

II. A TÉMAKÖR ELMÉLETI MEGALAPOZÁSA …............................................ 14

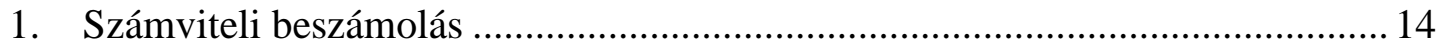

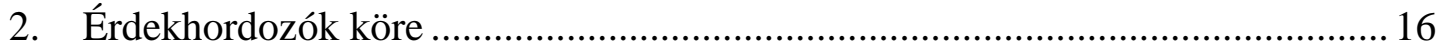

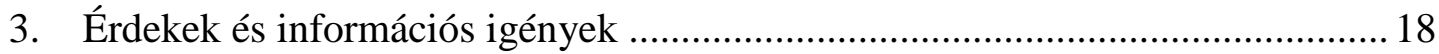

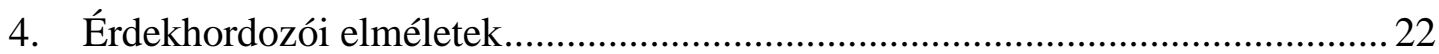

4.1. Hagyományos (korai) érdekhordozói elméletek ....................................... 22

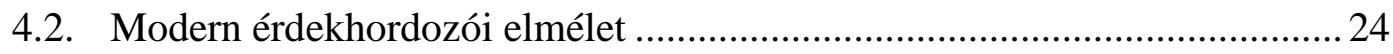

5. A számviteli szabályozás szükségessége ……..................................................25

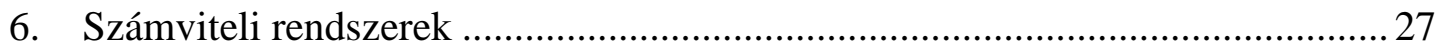

6.1. A számviteli szabályozási rendszereket befolyásoló tényezők .....................227

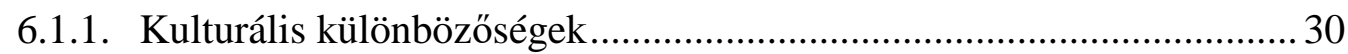

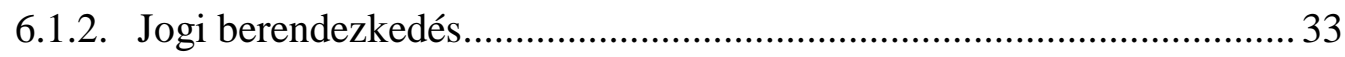

6.1.3. A vállalatfinanszírozás formája....................................................... 34

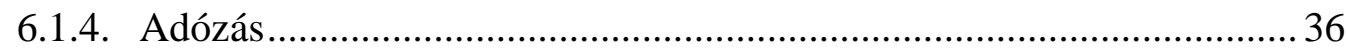

6.2. A számviteli rendszerek klasszifikációja .....................................................39

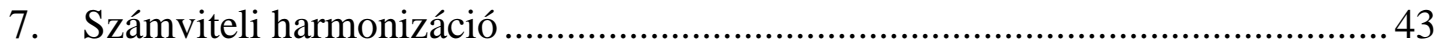

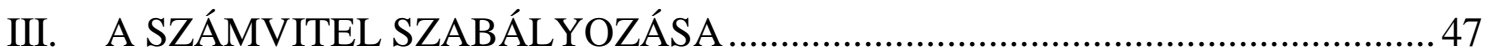

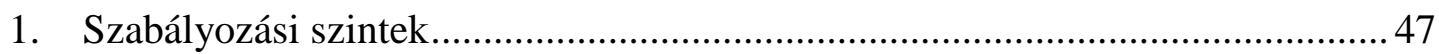

1.1. Nemzetközi számviteli szabályozási szint - IFRS rendszer ......................49

1.1.1. A nemzetközi pénzügyi beszámolási rendszer fejlődéstörténete .......... 49

1.1.2. A nemzetközi pénzügyi beszámolási rendszer alkalmazása .................50

1.2. Nemzetközi számviteli szabályozási szint - Európai Uniós irányelvek ......53

1.3. Nemzeti számviteli szabályozási szint - magyar számviteli rendszer ..........56

1.3.1. A magyar számviteli rendszer fejlődéstörténete ..................................56

1.3.2. Számviteli beszámolási rendszer Magyarországon.............................57 


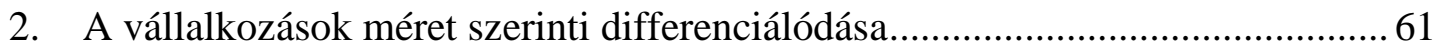

3. Adminisztratív terhek nagyságára vonatkozó felmérések ..................................67

4. KKV-k számviteli beszámolási rendszere.......................................................... 70

4.1. KKV számvitel - Nemzetközi szint - IFRS for SMEs ................................ 70

4.2. KKV számvitel - nemzeti szint................................................................. 76

4.2.1. Egyszerüsített éves beszámoló ........................................................... 76

4.2.2. Egyszerüsített beszámoló ….............................................................. 78

4.2.3. Sajátos egyszerüsített éves beszámoló ................................................ 78

4.2.4. Mikrogazdálkodói egyszerüsített éves beszámoló ............................... 80

4.2.5. Egyszerüsített adózási formák hatása a számviteli beszámolásra.......... 84

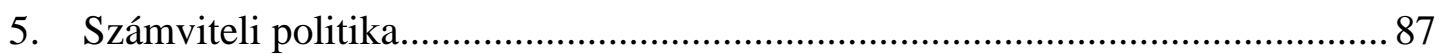

IV. AZ ALKALMAZOTT GYAKORLAT - EMPIRIKUS ........................................

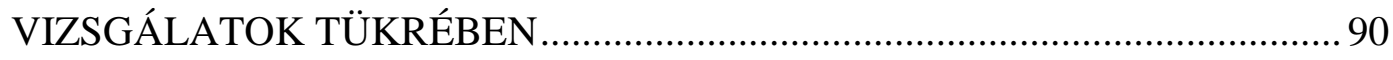

1. Érdekhordozók - információs igények - hasznosítás ....................................... 90

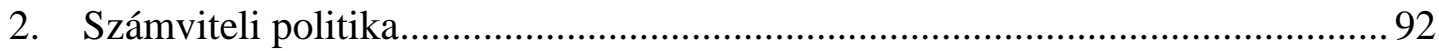

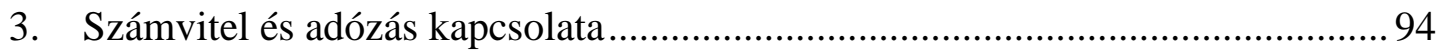

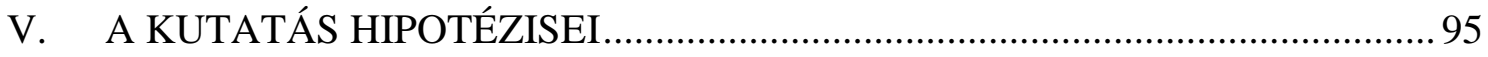

VI. A FELHASZNÁLT MÓDSZEREK ÉS A VIZSGÁLT ADATBÁZISOK ...........97

VII. A FELÁLLÍTOTT HIPOTÉZISEK ELLENÖRZÉSE....................................... 100

1. Számviteli politikai döntések vizsgálata (H1-H2) …....................................... 100

2. A számvitel és adózás kapcsolatának szorosságára vonatkozó vizsgálatok.............

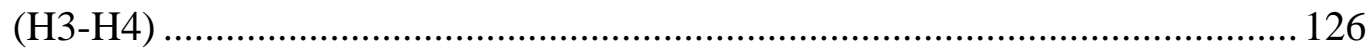

3. A nemzetközi szabályozásra vonatkozó kutatás (H5) ...................................... 134

VIII. AZ EREDMÉNYEK ÖSSZEFOGLALÁSA ÉS KÖVETKEZTETÉSEK .......... 140

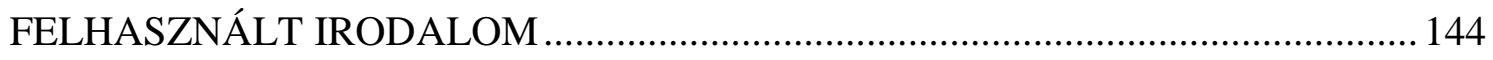

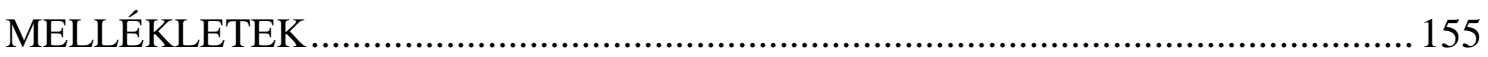




\section{TÁBLÁZATJEGYZÉK}

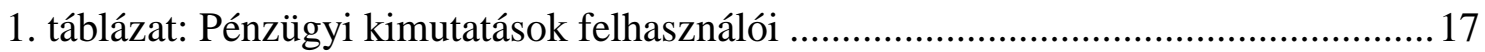

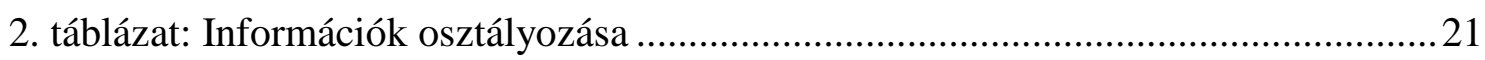

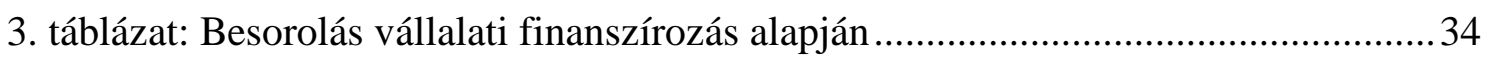

4. táblázat: Az adózás és a számvitel kapcsolata - Lambs ..........................................37

5. táblázat: Az adózás és a számvitel kapcsolata - Hoogendoorn ...................................38

6. táblázat: Az IAS/IFRS-ek használata a világon (tőzsdei) ........................................51

7. táblázat: Az IAS/IFRS-ek használata a világon (nem tőzsdei) …................................51

8. táblázat: Az IAS/IFRS-ek használata az EU-ban (2010) ..........................................52

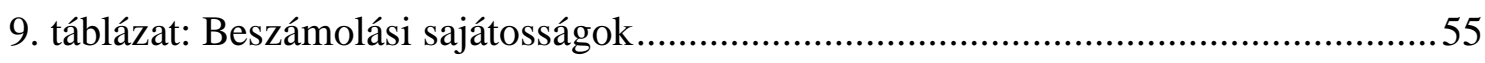

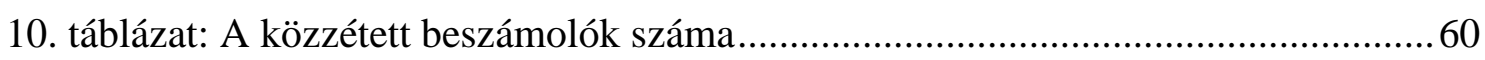

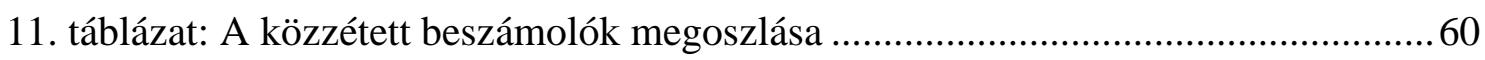

12. táblázat: Vállalkozások méret szerinti kategóriáinak határértékei ...........................61

13. táblázat: KKV-k Magyarországon - alapadatok ....................................................62

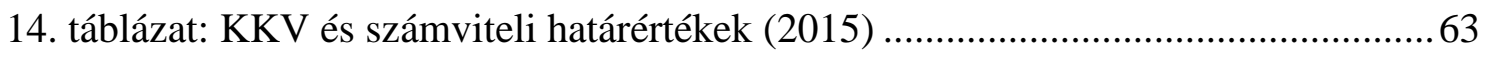

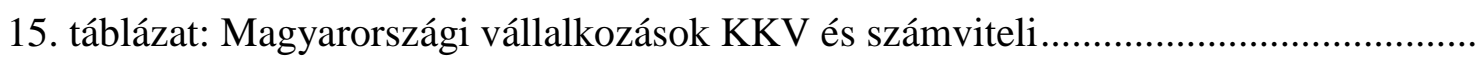

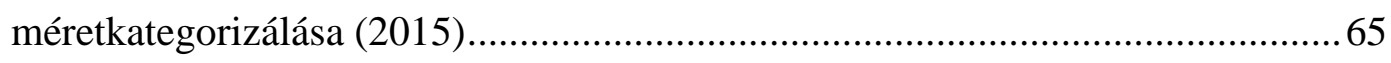

16. táblázat: Magyarországi vállalkozások KKV méretkategorizálása.............................

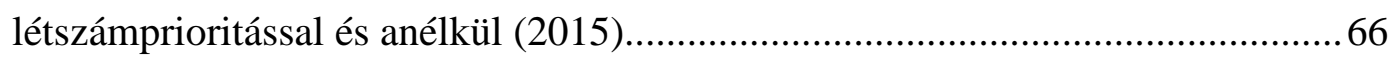

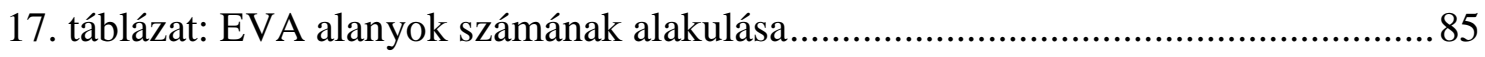

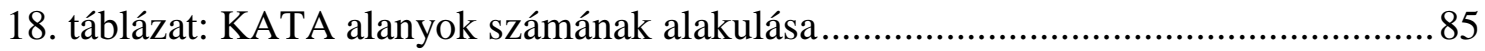

19. táblázat: Tárgyi eszközökre vonatkozó számviteli politikai döntések beszámolók 106

20. táblázat: Tárgyi eszközökre vonatkozó számviteli politikai döntések -

könyvelők

21. táblázat: Választott devizára vonatkozó számviteli politikai döntések -

beszámolók

22. táblázat: Választott devizára vonatkozó számviteli politikai döntések -

könyvelők

23. táblázat: Készletekre vonatkozó számviteli politikai döntések - beszámolók.........110

24. táblázat: Készletekre vonatkozó számviteli politikai döntések - könyvelők...........111

25. táblázat: Költség elszámolás és eredménykimutatás - beszámolók ....................... 112 
26. táblázat: Költség elszámolás és eredménykimutatás - könyvelök...........................113

27. táblázat: Alapítás-átszervezés, Kísérleti fejlesztés - beszámolók............................ 114

28. táblázat: Alapítás-átszervezés, Kísérleti fejlesztés - könyvelők.............................115

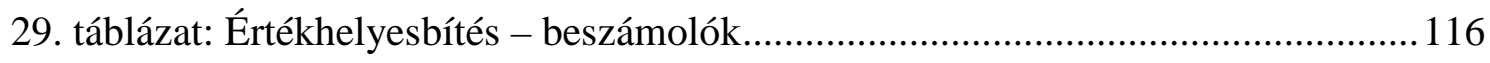

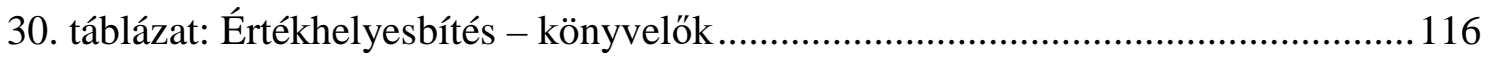

31. táblázat: Céltartalék jövőbeli költségekre - beszámolók ...................................... 117

32. táblázat: Céltartalék jövőbeli költségekre - könyvelők ........................................ 117

33. táblázat: Beruházási hitel nem realizált árfolyamvesztesége - beszámolók ............118

34. táblázat: Beruházási hitel nem realizált árfolyamvesztesége - könyvelők .............. 118

35. táblázat: Átlag körüli $95 \%$-os konfidencia intervallumok - H1 ........................... 120

36. táblázat: Átlag körüli $95 \%$-os konfidencia intervallumok - H2 .......................... 121

37. táblázat: Az időbeli elhatárolások relatív értéke (mérlegfőösszeghez .........................

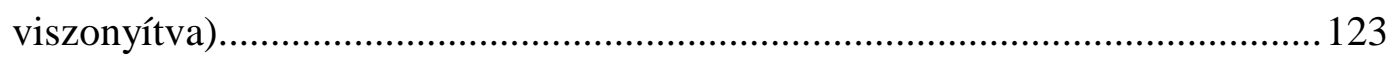

38. táblázat: Az időbeli elhatárolások relatív értéke (adózás előtti.....

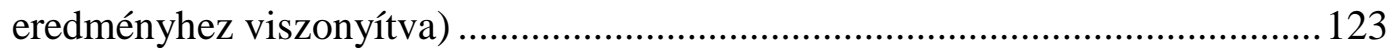

39. táblázat: Gazdálkodók megoszlása az Adózás előtti eredmény illetve az

Adóalap előjele szerint 126

40. táblázat: Gazdálkodók megoszlása az Adózás előtti eredmény és az Adóalap

elöjele szerint

41. táblázat: Gazdálkodók megoszlása a jövedelem-eltérés iránya szerint. 127

42. táblázat: Adóalap módosító tételek átlagos száma................................................. 130

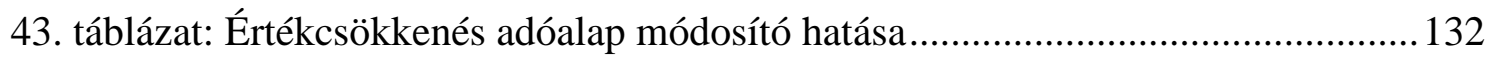

44. táblázat: Adóalap módosító tételek átlagos száma.................................................. 132

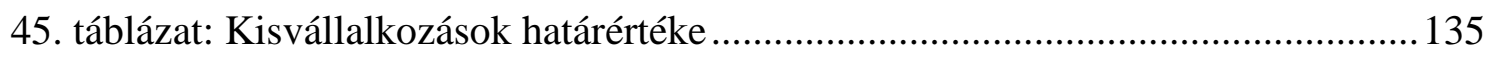

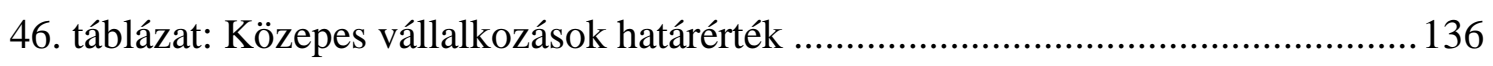

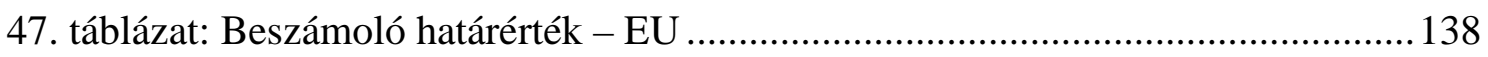




\section{ÁBRAJEGYZÉK}

1. ábra: A számviteli információk ábrázolása 19

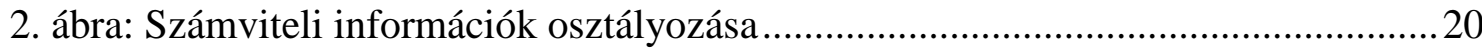

3. ábra: A számvitelelmélet és a szabályozás eltérő spektruma.....................................26

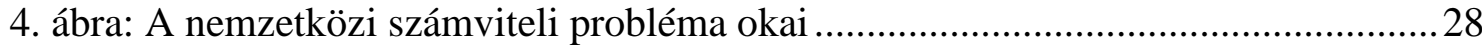

5. ábra: Gray-féle klasszifikáció a szabályozás és a végrehajtás dimenziójában.............32

6. ábra: Gray-féle klasszifikáció a mérés és a közzététel dimenziójában ........................32

7. ábra: Számviteli rendszerek hierarchikus csoportosítása (Nobes, 1980) .....................41

8. ábra: IFRS-t alkalmazó országok számviteli gyakorlatának összehasonlítása ............42

9. ábra: Nemzeti számviteli szabályok eltérései az EU-n belül ....................................44

10. ábra: Nemzeti számviteli szabályok eltérései az EU-n kívül ................................... 44

11. ábra: A globális szabályozásra ható tényezőcsoportok .........................................46

12. ábra: A magyar számviteli jogrend hierarchiája .................................................... 48

13. ábra: A magyar számviteli beszámolási rendszert befolyásoló határértékek alakulása

14. ábra: A KKV és számviteli beszámoló besorolási határértékeinek filozófiai különbsége

15. ábra: Adminisztratív célok ellátására külsősöknek fizetett összeg az. árbevétel százalékában.

16. ábra: Működő vállalkozások száma gazdasági forma szerint (1999-2014) .79

17. ábra: Új vállalkozások száma gazdasági forma szerint (1999-2014)........................ 80

18. ábra: Varianciaanalízis eredménye - H1 hipotézis .............................................120

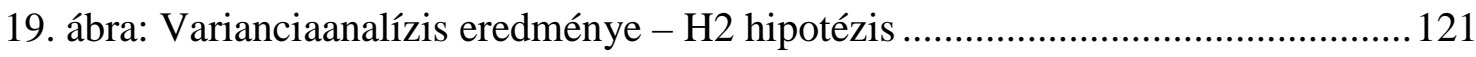

20. ábra: Relatív jövedelem-eltérés különböző mintanagyságok mellett...................... 129

21. ábra: Gazdálkodók megoszlása az adóalap módosító tételek (teljes) száma szerint.

22. ábra: Gazdálkodók megoszlása az adóalap módosító tétek (écs egyezőség nélküli) száma szerint ....

23. ábra: Gazdálkodók adóalap módosító tételeinek átlagos száma 133

24. ábra: Kisvállalkozások határérték klaszter elemzésének dendrogramja 135

25. ábra: Közepes vállalkozások határérték klaszter elemzésének dendrogramja......... 136

26. ábra: Beszámoló határérték klaszter elemzésének dendrogramja. 137

27. ábra: A beszámoló átlagos értékhatárai az EU értékhatáraihoz viszonyítva. 139 


\section{RÖVIDÍTÉSEK JEGYZÉKE}

AAA: American Accounting Association (Amerikai Számviteli Társaság; USA)

EÉ: Egyszerűsített éves beszámoló (Simplified annual report)

ÉB: Éves beszámoló (Annual report)

EVA: Egyszerüsített vállalkozói adó (Simplified Entrepreneurial Tax)

GAAP: Generally Accepted Accounting Principles (általánosan elfogadott számviteli elvek)

IAS: International Accounting Standard (nemzetközi számviteli standard)

IASB: International Accounting Standards Board (Nemzetközi Számviteli Standard Testület)

IASC: International Accounting Standards Committee (Nemzetközi Számviteli Standard Bizottság)

IASCF: International Accounting Standards Committee Foundation (Nemzetközi Számviteli Standard Bizottság Alapítvány)

IFRIC: International Financial Reporting Interpretations Committee (Nemzetközi Pénzügyi Beszámolási Értelmezési Bizottság és az általa kiadott értelmezések)

IFRS: International Financial Reporting Standard (nemzetközi pénzügyi beszámolási standard)

KATA: Kisadózók tételes adója (Fixed-rate tax of small taxpayer enterprises)

MG: Mikrogazdálkodói beszámoló (Microbusiness report)

SIC: Standing Interpretations Committee (Állandó Értelmezési Bizottság és az általa kiadott értelmezések)

SME: Small and Medium-sized Entities (kis- és közepes méretü vállalkozások)

Szv. Tv.: Számviteli törvény (Magyarország):

2000. évi C. törvény a számvitelről

TAO: Társasági adó (Magyarország) 


\section{BEVEZETÉS}

A számviteli beszámolási rendszerek szabályozása nemzetközi és nemzeti szinten egyaránt napirenden lévő terület, a harmonizációra vonatkozó törekvések felerősödése tapasztalható. Ez a folyamat a nagyvállalatokra vonatkozóan már korábban is megfigyelhető volt, napjainkban azonban a kis- és középvállalkozások számviteli beszámoltatására vonatkozó szabályrendszerek felülvizsgálta került inkább a fókuszba. Ezt támasztják alá a közelmúlt eseményei, ide értve, hogy 2009-ben megszületett a kisvállalkozásokra vonatozó nemzetközi pénzügyi beszámolási standard (KKV IFRS), 2013-ban elfogadásra került az Európai Unió új irányelve a számvitelről és Magyarországon bevezetésre került a mikrogazdálkodói egyszerűsített éves beszámoló. Előtérbe kerültek a számviteli beszámolók hasznosságával, felhasználásával, az érdekhordózók megjelenésével és információigényével kapcsolatos kérdések.

A dolgozat vizsgálati fókuszában a kis- és középvállalkozásokra vonatkozó számviteli beszámolási rendszer áll, annak szabályozása, alkalmazása és hasznosítása.

$\mathrm{Az}$ értekezés első részében a téma elméleti hátterét tekintem át a vonatkozó szakirodalom feldolgozásán keresztül. Ennek során kitérek az érdekhordozókra, azok információs igényeire, a szabályozás szükségességére. Ezt követően áttekintem az eltérő számviteli rendszerek kialakulásának okait, ide értve a kultúra, a jogrendszer, a finanszírozási forma és az adózás hatását.

Az értékezés második része a felvázolt elmélet gyakorlati megvalósításáról szól, a szabályozás különböző szinteken történő megjelenéséről, külön kiemelve a kis- és középvállalkozások vonatkozó nemzetközi és nemzeti szintű szabályozást. Bemutatom a gazdálkodó szervezetek besorolásával kapcsolatos vonatkozó elöírásokat a KKV és a számviteli szempontok szerint.

Az értékezés harmadik részében a témához kapcsolódóan áttekintem az külföldi és hazai empirikus kutatásokat: az érdekhordozók és információs igényeikre, a számviteli beszámolók szabályozására, a számviteli politikára, illetve a számvitel és adózás kapcsolatára vonatkozóan. 
Nemzetközi kutatások közül az eltérő számviteli rendszerek vizsgálatával foglalkozó és az országokat szabályrendszerek alapján hierarchikus rendszerbe foglaló Nobes - Parker [2008], a KKV IFRS-t vizsgáló Jermakowicz-Epstein [2010], és az Európai Unió által készítetett, a tagállamok számviteli rendszerét feltérképező tanulmányok jelentettek kiindulási alapot a vizsgálataimhoz.

A magyar számvitel-kutatási előzményként ki kell emelnem Bosnyák [2003] a számviteli politikai döntésekkel foglalkozó, Lakatos [2009] az elmélet és szabályozás összefüggéseit és a pénzügyi kimutatások hasznosságát vizsgáló, illetve Kántor [2010] a számviteli információk felhasználásának és a vállalat méretének kapcsolatát feltáró munkáit.

A bemutatott elmélet és empirikus kutatások rendszerének megfelelően három területre állítottam fel hipotéziseimet, melyek ellenőrzésével az alábbi kutatási kérdésekre keresem a választ:

- számviteli szempontból ki minősül KKV-nak, a határértékek meghatározása milyen filozófia mentén történik?

- milyen egyszerüsítési lehetőségek vannak jelenleg a KKV szektor számára a számviteli beszámolási rendszerben és mennyire élnek ezekkel a vállalkozások?

- miben szabad / lehet egyszerüsíteni a KKV-kra vonatkozó számviteli előírásokat?

- mennyire szoros a kapcsolata a társasági adónak a számvitellel a KKV-k esetében?

- nemzetközi összehasonlításban milyen tényezők érvényesülnek a KKV-kra vonatkozó számviteli szabályok kialakításakor?

Ezek alapján fogalmaztam meg a negyedik fejezetben ismertetett hipotéziseimet, amelyekből kettő az alkalmazott számviteli politikai döntések, kettő a számvitel, az adózás és a vállalkozások méret közötti kapcsolata közötti összefüggésekre, míg az ötödik a nemzetközi számviteli szabályozásra vonatkozik.

Az értékezés ötödik részében bemutatom a hipotézisek teszteléséhez használt adatbázisokat és az alkalmazott matematikai-statisztikai módszereket. Az elemzéshez öt adatbázist használtam, amelyek közül egy külső forrásból származik (társasági adóbevallások adatai), a másik négy saját gyüjtés (éves, illetve egyszerüsített éves 
számviteli beszámolók, könyvelö irodák, nemzetközi beszámolás szabályaira vonatkozó adatok).

Ezt követően ismertetem a vizsgálat során elért eredményeimet, bemutatva a kutatás lépeseit az adatgyüjtéstől kiindulva, a vizsgálat lefolytatásán keresztül az eredmények megszületéséig. Jelen kutatás összehasonlítva a korábbi - a vállalati méret függvényében a vállalkozások számviteli politikájára, illetve a számvitel és adózás kapcsolatára irányuló - kutatásokkal a vizsgálat fókuszába állított egyszerűsítési törekvések és lehetőségek vizsgálatában lép tovább.

A disszertáció céljaként tüztem ki, hogy hozzájáruljak a magyarországi kis- és középvállalkozások számviteli beszámoltatási rendszerére vonatkozó szabályozás fejlesztéséhez. Az elemzések alapján levont következtetéseimet és javaslataimat a záró fejezetben foglaltam össze. 


\section{A TÉMAKÖR ELMÉLETI MEGALAPOZÁSA}

Az első rész a számviteli beszámolási rendszer elméleti hátterét világítja meg. Kiindulva az érdekhordozók információs igényéből, bemutatva a számvitel fejlődését az érdekhordozói elméleteken keresztül, eljutva a szabályozás szükségességéig. Tárgyalásra kerülnek a számviteli rendszerek különbözőségei, ezek okai, valamint a számviteli harmonizációs folyamat.

\section{Számviteli beszámolás}

A számvitel fogalmának meghatározását az idők folyamán a szakma sok képviselöje megtette: a megfigyelés, mérés, rögzítés, megjelenítés, nyomon követés, feljegyzés, ellenőrzés, elemzés, közlés fogalmak felhasználásával és ezek különféle kombinációival. ${ }^{1}$ Ezek közül a következő kettőt emeltem ki.

Baricz szerint a számvitel „a vagyon és vagyonváltozások megjelenítésének, nyomon követésének és kommunikálásának tudománya és gyakorlata”. (Baricz [2009] 9. oldal)

Amerikai Számviteli Szövetség értelmezésében „a számvitel a gazdasági információk azonosításának, mérésének, és közlésének a folyamata, amely biztosítja a jól tájékozottságot az információ-felhasználók döntéseiben”. (Benedict - Elliot [2001] 3. oldal)

A számvitel feladatának meghatározásakor az információnyújtás egyértelműen megjelenik. Baricz [2009] rámutat, hogy a számvitelnek, mint gyakorlati tevékenységnek információt kell szolgáltatni a vállalkozás vagyonáról, a vagyonban bekövetkezett változásokról, a vagyonváltozás hatásairól. Szükséges mindez:

- egyrészt a vállalkozással kapcsolatba kerülő külső érdekhordozók számára döntéseik megalapozása és utólagos értékelése céljából;

\footnotetext{
${ }^{1}$ lásd például Deák [2006] 10-13. oldal
} 
- másrészt a vállalkozás vezetőinek az irányításhoz szükséges vezetői döntések kialakításához és azok utólagos értékeléséhez;

- harmadrészt a vállalkozás folyamataiban résztvevő igazgatási feladatokat végző személyeknek feladatik ellátásához.

Ugyanakkor elmondható, hogy információs igények különböző mélységben és szerkezetben, eltérő időintervallumban merülhetnek fel.

Az információnyújtás egyik eszköze a pénzügyi beszámoló, amelyet a különféle szabályozások a következők szerint fogalmaznak meg.

Az IFRS-ek és a US GAAP közös koncepcionális keretelvei szerint: ,,$A(z$ általános célú) pénzügyi beszámolás feladata, hogy olyan pénzügyi információkat nyújtson a gazdálkodó egységről, amelyek a jelenlegi és a potenciális befektetők, kölcsönnyújtók és egyéb hitelezők számára hasznosak finanszírozási döntéseik meghozatalakor".

A Nemzetközi pénzügyi beszámolási standardok rámutatnak, hogy a beszámolás eredményeként létrejövő kimutatások célja:

„a gazdálkodó egység pénzügyi helyzetéröl, pénzügyi teljesítményéről és cash flow-iról olyan információt nyújtsanak, amelyek a felhasználók széles köre számára hasznos gazdasági döntéseik meghozatala során" (IAS 1. 9. bek.)

Hasonló a magyar számviteli törvény (2000. évi C. törvény) megközelítése is. A preambulum alapján:

„A piacgazdaság müködéséhez nélkülözhetetlen, hogy a piaci szereplök számára hozzáférhetően, döntéseik megalapozása érdekében mind a vállalkozók, mind a nem nyereségorientált szervezetek, valamint az egyéb gazdálkodást folytató szervezetek vagyoni, pénzügyi és jövedelmi helyzetéről és azok alakulásáról objektív információk álljanak rendelkezésre”.

A törvény (4. § (1) és (2) bekezdése) elöírja, hogy a gazdálkodó a müködéséről, vagyoni, pénzügyi és jövedelmi helyzetérő beszámolót köteles készíteni, amelynek megbízható és valós összképet kell adnia a gazdálkodó vagyonáról, annak összetételéről (eszközeiről és forrásairól), pénzügyi helyzetéről és tevékenységének eredményéröl. 


\section{2. Érdekhordozók köre}

A számviteli beszámolók definícióiban közös elem, hogy mindegyike megfogalmaz felhasználót. A vállalat müködése során kapcsolatba kerül különféle érdekekkel rendelkező és ebből adódóan eltérő információs igényü gazdasági szereplökkel ${ }^{2}$.

Baricz érdekhordozónak - a vállalatot koalícióként értelmező vállalatfelfogás alapján - a vállalkozással közvetlen kapcsolatba kerülő természetes és jogi személyeket tekinti. (Baricz [2009] 10. oldal)

Lakatos definíciója szerint az érdekhordózók azok a személyek (vagy személyek egyesülései), akiknek érdekében áll egy gazdálkodó egységről a számvitel által előállítható gazdasági természetű adatokat szerezni. (Lakatos [2009] 14. oldal)

Az érdekhordózókat alapvetően két nagy csoportba osztja a szakirodalom: a belső érdekhordozói csoport a tulajdonosok, a vállalatvezetők (menedzsment) és az alkalmazottakat körét jelenti, míg a külső a vevőket, szállítókat, a hitelezőket és az állami szervezeteket foglalja magába.

Chikán [2008] további szereplőkkel egészíti ki az érdekhordózók körét beleértve minden olyan személyt vagy csoportot, aki/ami lényeges, tartós és kölcsönös kapcsolatban áll a vállalkozás müködésével. Így ide sorolja a versenytársakat, stratégiai partnereket, helyi és önkéntes állampolgári közösségeket, természeti környezetet.

Riahi-Belkaoui [2000] még ennél is tágabban értelmezi a felhasználók körét, a vállalkozással közvetlen, illetve közvetett kapcsolatban lévő csoportra bontva a pénzügyi kimutatások felhasználóit.

2 a szakirodalomban található elnevezések, amelyeket a továbbiakban szinonimként használok: érdekhordozók, érintettek, stakeholderek 
1. táblázat: Pénzügyi kimutatások felhasználói

\begin{tabular}{|l|l|}
\hline \multicolumn{1}{|c|}{ Közvetlen felhasználók } & \multicolumn{1}{c|}{ Közvetett felhasználók } \\
\hline tulajdonos (részvényes) & pénzügyi elemzők és tanácsadók \\
\hline hitelezők és szállítók & tőzsdék \\
\hline menedzsment & ügyvédek \\
\hline adóhatóság & szabályozási és nyilvántartási hatóságok \\
\hline munkavállalók & pénzügyi sajtó és adatszolgáltatók \\
\hline vevők & kereskedelmi szövetségek \\
\hline & szakszervezetek \\
\hline & versenytársak \\
\hline & nagyközönség \\
\hline & egyéb kormányzati szervek \\
\hline
\end{tabular}

Forrás: Riahi-Belkaoui [2000] 90. oldal alapján saját szerkesztés

A dolgozatban az érdekhordózói kört a tágabb értelemben használom, de alapvetően a közvetlen felhasználói körre fókuszálva folytattam a vizsgálatokat. 


\section{3. Érdekek és információs igények}

A bemutatandó információk köre alapvetően az érdekhordozók igényeiből vezethető le, amelyeket röviden a következők szerint lehet bemutatni.

A tulajdonosi kör - amely többféleképpen differenciálódhat ${ }^{3}$ - a megtermelt és a realizált jövedelem nagyságára és annak időbeli alakulására, a befektetésük értéknövekedésére, illetve az osztalékra vonatkozóan igényel információkat.

A menedzserek - a vállalkozás vezetői tevékenységét alkalmazottként ellátó szereplők - érdekei alapvetően javadalmazásukhoz, illetve személyes ambícióikhoz (karriercéljaikhoz) köthetőek, amelyek megítélése szintén számviteli információkon is alapul (például nyereség, saját tőke értékének növekedése).

A munkavállalók érdeke a jövedelmük megfelelő mértékü növekedése mellett a munkakörülményeik javulása, munkahelyük biztonságos volta, így az ezekre vonatkozó múltban történt és a jövőben várható információkat igénylik.

A hitelezők - mint a vállalkozás részére meghatározott időre pénzeszközöket rendelkezésre bocsátó szereplők - abban érdekeltek, hogy a vállalkozás a szerződésben rögzített törlesztési és kamatfizetési kötelezettségeinek eleget tegyen. Az ö információs igényük alapvetően a vállalkozás jövőbeli fizetőképességére és fizetőkészségére irányul.

A piaci partnerek - a meglévő és potenciális vevők és szállítók - alapvetően a hosszú távú és biztonságosan müködő kapcsolat kiépítésében érdekeltek. A vállalkozás - beszerzési, értékesítési és árpolitikáján túlmenően - gazdasági és pénzügyi helyzetére vonatkozóan igényelnek információt.

Az állam - amely főként az adókon keresztüli jövedelem elvonás formájában kapcsolódik a vállalkozáshoz - információigénye az elért eredményhez, forgalomhoz, illetve bizonyos tevékenységek volumenéhez kapcsolódik.

\footnotetext{
${ }^{3}$ Megkülönböztethetünk rövid és hosszú távú befektetőket, illetve kis és nagy tulajdonosokat. Ezeknek a csoportoknak eltérő érdekeik, jogaik vannak, amely hatással van az általuk igényelt információkra.
} 
A szereplök között több területen - így a vállalkozásból való jövedelemkivonás vagy jövedelemvisszatartás, illetve az információk nyilvánosságra hozatala vagy visszatartása - is érdekütközés figyelhető meg. Ennek, illetve magának az érdekhordozók és az általuk támasztott információigények összefüggéseinek részletesebb kifejtésével többek között Baricz [1997a], Benedict - Elliott [2001], Glautier - Underdown [2001] és Lakatos [2009] foglalkozik.

Az érdekhordozók tehát a vállalkozás vagyoni (financial position), pénzügyi (changes in financial position) és jövedelmi (financial performance) helyzetet bemutató információkat igényelnek, amelyek világosnak (érthetőnek és áttekinthetőnek), relevánsnak, megbízhatónak (valósághünek, semlegesnek, óvatosnak, teljesnek) valamint összehasonlíthatónak kell lenniük. Az információkkal szemben támasztott minőségi követelményeinek részletes bemutatása az IFRS keretelvekben, a US GAAP elöírásaiban, illetve Baricz [2009] müvében találhatóak.

Ezek alapján kérdésként merülhet fel, hogy a vállalkozás környezetében korlátlanul rendelkezésre álló adatok közül, milyen szürők alkalmazásával juttassunk el információt (értelmezett adatot) a felhasználókig. El kell dönteni, hogy mit gyüjtsünk, illetve rögzítsünk, hogyan dolgozzuk fel ezeket, illetve mit tegyünk közzé azokból, vagyis mi kerüljön a pénzügyi kimutatásokba, illetve jelentésekbe.

Az információszolgáltatás ezen folyamatát a következő ábra szemlélteti.

1. ábra: A számviteli információk ábrázolása

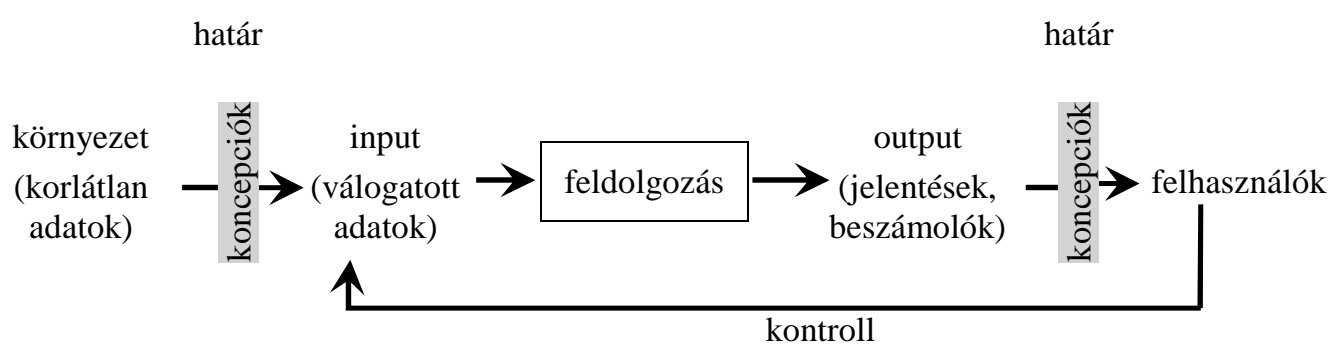

Forrás: Glautier - Underdown [2001] 38. oldal (saját fordítás)

A „minél több, minél részletesebb” irány ellen szól, hogy egy bizonyos szint után az újabb adat már ront az érdekhordozó informáltságán, nehezíti a döntést, hiszen hosszabb az értelmezési és kiválasztási idő, ezáltal nagyobb energiabefektetést igényel a 
felhasználótól. Ezt erősíti meg disszertációjában Lakatos [2009] is két kutatást ${ }^{4}$ idézve, amelyek rámutatnak, hogy egy optimális ponton túl az informálás már inkább káros.

Cyert - Ijiri [1974] az információk osztályozására és az eltérő érdekekből fakadó konfliktusok bemutatására három csoportot különít el: gazdálkodók, felhasználók, számviteli szakma. A következő diagram a gazdálkodó által - önkéntes vagy kötelező

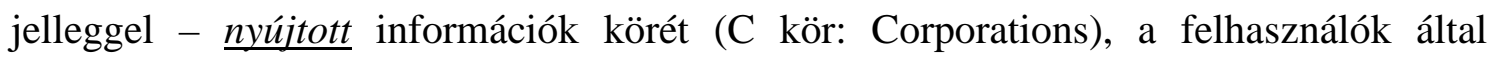
hasznosnak vélt, emiatt igényelt információk halmazát (U kör: Users) és az adatok azon részét, amelyet a számvitel - mint szakma - képes kezelni, meghatározni (P kör: The Accounting Profession) jeleníti meg.

2. ábra: Számviteli információk osztályozása

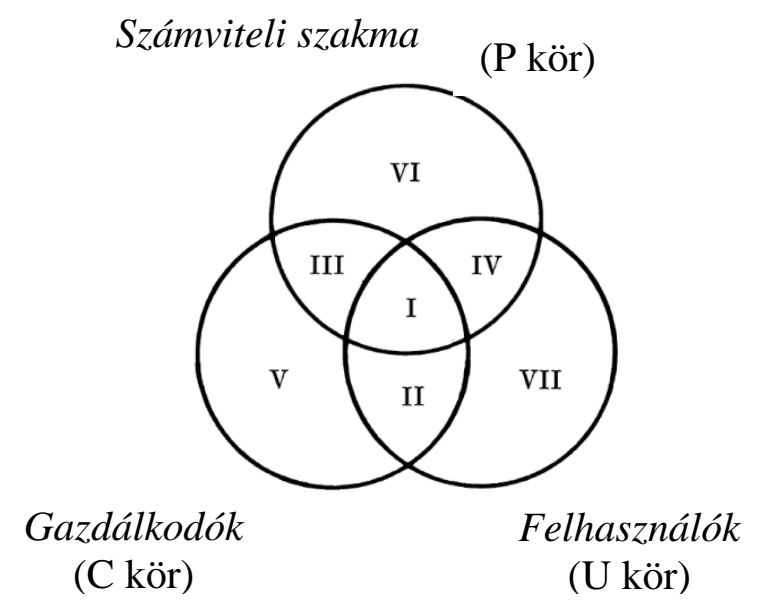

Forrás: Cyert - Ijiri [1974] 30. oldal (saját fordítás)

A körök - amelyek egy adott állapotot jelenítenek meg az adatokról - nagysága és elhelyezkedése természetesen változhat. Szerencsés esetben egymáshoz közelednek és ezáltal a közös terület - tehát a hasznos, meghatározható és nyújtott információk halmaza - növekszik.

\footnotetext{
${ }^{4}$ Gonedes és Dopuch (1974) valamint Piontkowski és Hoffjan (2009)
} 
Az ábra egyes részeinek értelmezését a 2. táblázat foglalja össze.

2. táblázat: Információk osztályozása

\begin{tabular}{|c|l|l|}
\hline Kat. & \multicolumn{1}{|c|}{ Értelmezés } & \multicolumn{1}{c|}{ Megjegyzés } \\
\hline I & nyújtott, hasznos és meghatározható & $\begin{array}{l}\text { legkedvezőbb eset } \\
\text { nincs teendő }\end{array}$ \\
\hline II & $\begin{array}{l}\text { nyújtott és hasznos, } \\
\text { de nem meghatározható }\end{array}$ & $\begin{array}{l}\text { túl szubjektív } \\
\text { (pl. elörejelzések) }\end{array}$ \\
\hline III & $\begin{array}{l}\text { nyújtott és meghatározható, } \\
\text { de nem hasznos }\end{array}$ & $\begin{array}{l}\text { hamar eltúnik ez a halmaz } \\
\text { (pl. milliók utáni számjegyek) }\end{array}$ \\
\hline IV & $\begin{array}{l}\text { meghatározható és hasznos, } \\
\text { de nem nyújtott }\end{array}$ & $\begin{array}{l}\text { Kérdés, hogy közzé kellene-e tenni } \\
\text { (pl. belső részletes számítások) }\end{array}$ \\
\hline V & $\begin{array}{l}\text { nyújtott, } \\
\text { de nem meghatározható és nem hasznos }\end{array}$ & $\begin{array}{l}\text { hamar eltúnik ez a halmaz } \\
\text { (ha a gazdálkodó ezt felismeri) }\end{array}$ \\
\hline VI & $\begin{array}{l}\text { meghatározható, } \\
\text { de nem nyújtott és nem hasznos }\end{array}$ & $\begin{array}{l}\text { nincs rá kereslet } \\
\text { (nem kell vele foglalkozni) }\end{array}$ \\
\hline VII & $\begin{array}{l}\text { hasznos, } \\
\text { de nem nyújtott és nem meghatározható }\end{array}$ & $\begin{array}{l}\text { nehezen meghatározható és a } \\
\text { bizonytalanság miatt nem szívesen } \\
\text { közölt adatok } \\
\text { (pl. aktuális érték, ha jelentősen } \\
\text { eltér a bekerülési értéktől) }\end{array}$ \\
\hline
\end{tabular}

Forrás: Cyert - Ijiri [1974] 30-32. oldal alapján saját szerkesztés

A gyakorlatban az elméletben vázolt modell kétféle módon is egyszerüsödhet. Egyrészt az egyes szerepkörök nem feltétlenül különülnek el egymástól (erre az egyik legszemléletesebb példa a kisebb gazdálkodóknál figyelhető meg, ahol a tulajdonos, a menedzser és a munkavállaló gyakran egyetlen személyben testesül meg) másrészt, ha valamely érdekhordozó nem jelenik meg (például hitelezők a kisvállalkozások jelentős részénél). Ez természetesen az információigények és az ebből eredő érdekütközések módosulásához (csökkenéséhez) vezethet. 


\section{4. Érdekhordozói elméletek}

Az angolszász irodalomban az érdekhordozói elméletek megismerésén keresztül tanúi lehetünk a számvitel XX. századi fejlődésének. Ezen elméletek jellemzően egyegy érintett szemszögéből vizsgálták, hogy kinek készül a pénzügyi beszámoló és neki milyen információigénye van.

Az érdekhordozói elméletek részletesebb bemutatását Baricz [1997a], Lakatos [2009], Riahi-Belkaoui [2000] és Schroeder - Clark - Cathey [2009] munkáiban találhatjuk meg, itt csak a fő gondolatok összefoglalására vállalkoztam, amely során feltüntettem az elméletek képviselőit és a publikálás dátumát is.

\subsection{Hagyományos (korai) érdekhordozói elméletek}

A Tulajdonosi elmélet (Proprietary Theory) - Henry Rand Hatfield (1927) - a vállalkozást a tulajdonossal azonosítja. A beszámolás egyetlen céljának a tulajdonos informálását, feladatának a tulajdonosok között felosztható vagyon nagyságának meghatározását tekinti.

$\Sigma$ Eszköz $-\Sigma$ Kötelezettség = Tulajdonosokra jutó vagyon

A tulajdonoson kívüli érdekhordozók nem érvényesülnek.

Az Egységelmélet (Entity Theory) - William A. Paton (1922) - a vállalatot önálló gazdasági egységként értelmezi elkülönítve a tulajdonostól. Nem azonosít be érdekhordozókat, külső információs igényeket nem képes kielégíteni. Célja a vállalkozás működésének hatékonyságának (nyereségének) kimutatása, amelyet a beszámolón keresztül valósít meg.

$\Sigma$ Eszköz $=\Sigma$ Rendelkezésre álló tőke

Az Alapelmélet (Fund Theory) - William J. Watter (1947) - szerint minden eszköz egy adott célnak van alárendelve és mindegyikhez hozzárendelhető a forrásoldali - nem feltétlenül egyetlen elem - megfelelője (alapja). Ebből a kapcsolatból levezetve feltételez egy objektív elszámolási rendszert, amely lehetővé teszi, hogy minden 
érdekhordozó - elismeri, hogy több érintett is van párhuzamosan - összeállíthassa az aktuális célra szükséges információt.

$$
\Sigma \text { Eszköz }=\Sigma \text { Alapok (eszközökön lévő korlátozások) }
$$

Az egyértelmü összerendelés nehezen valósítható meg, nem sikerült gyakorlatban is kivitelezhető megoldást találni.

A Vállalat elmélet (Enterprise Theory) - Waino Soujanen (1958) - a vállalatot (elsősorban tőzsdei vállalkozásokat) a forrásbiztosítók egy közös célja érdekében létrehozott intézményként definiálja. A menedzsment feladatának alapvetően a megfelelő mértékü osztalék biztosítását tekinti, illetve a kapcsolat fenntartást a munkavállalókkal, a kereskedelmi partnerekkel és a kormányzati szervekkel.

A Reziduális tôkeelmélet (Residual Equity Theory) - George J. Staubus (1959) - a tulajdonosi és az egységelméletet kombinációja. Az érdekhordozók közül kiemeli a reziduális tőke tulajdonosait (akiknek a céggel szembeni követeléseit a többi finanszírozó után kell kiegyenlíteni, tehát alapvetően a tőketulajdonosok, illetve speciális esetben bizonyos hitelezői kör) és őket teszi a beszámoltatás címzettjének, mivel ők viselik a végső kockázatot.

$\Sigma$ Eszköz $-(\Sigma$ Kötelezettségek $+\Sigma$ Elsőbbségi részvények $)=$ Reziduális tőke

A Menedzsment elmélet (Commander Theory) - Goldberg (1965) - kiemeli az érdekhordozók közül a vállalatvezetést, mint a gazdálkodó egység döntéshozóját. A számviteli beszámoló céljának az ő információigényük kiszolgálását tekinti, figyelmen kívül hagyva a többi érdekhordozót.

A korai érdekhordozói elméletek jellemzően az érdekhordozói kört erősen leszükítve, egy-egy szereplőt (például tulajdonost, vállalatvezetést) a központba helyezve próbálták az információs igényeket kielégíteni, illetve bizonyos esetekben egyáltalán nem azonosítanak be olyan személyeket, akiknek az érdekeit figyelembe vennék az beszámolási rendszer kialakításakor, ezáltal a kialakult gyakorlattal ellentmondásba kerülnek. 


\subsection{Modern érdekhordozói elmélet}

A vállalatelméleti kutatások által meghatározott koalíciós elmélet a vállalatot olyan koalíciónak tekinti, amely összefogja a vállalattal közvetlen kapcsolatba kerülő érdekhordozókat, akik céljaik érdekében összefognak. Az eltérő célok ütköztetése alapján alakul ki a követendő irány, mint az egyéni célok eredője. Ennek számviteli leképezéseként a vállalati beszámoló a koalíció tagjainak (nem egy-egy, hanem mindegyik) információ igényeit kell, hogy kielégítse. Az egyes érdekhordozók céljai (legalább részben) eltérőek, ebből adódóan adatigényük is különböző lehet. Így a beszámolás elemeinek mélységét, terjedelmét és tartalmát illetően kompromisszumot kell kötni, ami felveti a számviteli szabályozás szükségességét. 


\section{A számviteli szabályozás szüikségessége}

A bemutatott elméletekből levezetve megállapítható, hogy ha egynél több érdekhordozó azonosítható, akkor szükség van/lehet szabályozásra, hogy a keletkezett érdekellentétek feloldhatóak legyenek és rendelkezésre álljanak a megfelelő tartalmú számviteli kimutatások. Szabályozás nélkül bizonyos érdekeket (pl. kisrészvényesek, hitelezők) csak részben vagy egyáltalán nem (pl. adóhatóság számára adatszolgáltatások) lennének hajlandóak önszántukból teljesíteni a vállalkozások.

Léteznek ugyanakkor olyan teóriák is, amelyek szerint a szabályozás szükségtelen, mert úgy vélik, hogy automatikusan kialakulnak a megfelelő minőségü, mélységü és mennyiségü számviteli adatok, illetve pénzügyi kimutatások.

Ide tartozik a megbízó-ügynök elmélet (Agency Theory), amelynek számviteli aspektusa, hogy a menedzsment (ügynök) saját érdeke a beszámoló összeállítása, hiszen a tulajdonos (megbízó) ez alapján ítéli meg a teljesítményüket, ami a javadalmazásuk alapjául szolgálhat.

A jelzéselmélet (Signaling Theory) szerint a vállalkozás saját, jól felfogott érdeke, hogy önkéntesen szolgáltassa a szükséges és megfelelő minőségü adatokat. Megfelelő mennyiségü és minőségü adat nélkül a vállalat külső megítélése kedvezőtlenebb, alacsonyabbra árazza be a piac a vállalkozást.

A téma mélyebb bemutatását Lakatos [2009] munkájában találhatjuk meg.

A gyakorlat azonban a szabályozás szükségességét igazolta vissza. A számvitel elmélet azonban nagyobb terület ölel fel, mint a számvitel szabályozása, s a következő ábra jól szemlélteti e kettő viszonyát. 
3. ábra: A számvitelelmélet és a szabályozás eltérő spektruma

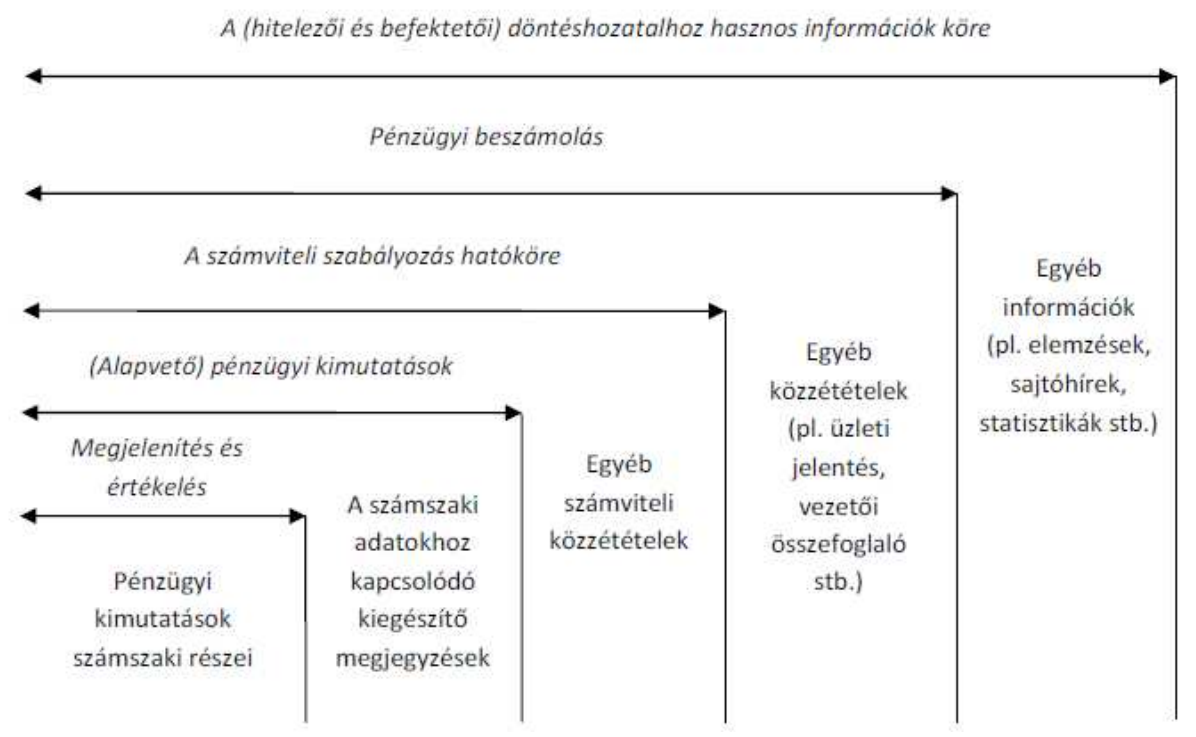

Forrás: FASB CON5 alapján (Barth [2000] 9. oldal)

A számviteli szabályozása során Baricz [1997a] szerint az alábbi tényezőket kell meghatározni:

- a szabályozás kinek vagy kiknek az érdekeit szolgálja,

- az eltérő érdekek milyen filozófia mentén oldhatóak fel,

- azon vállalkozások köre, akire a szabályozás vonatkozik,

- a beszámoló részletezettsége és tartalma,

- a beszámoló fő részeire és mellékleteire vonatkozó formai és tartalmi kritériumok,

- a beszámoló egyes részeinek összeállításkor figyelembe veendő alapelvek,

- az alkalmazott értékelési elvek és eljárások,

- hitelesítésre és nyilvánosságrahozatalra vonatkozó teendők.

A számvitel szabályozása alapvetően a külső információs igények kielégítését szolgálja és a vállalkozás beszámolójának összeállítására irányul. A szabályozás módja és a kialakult számviteli beszámolási rendszerek eltérő képet mutatnak a nemzetközi összehasonlítás tükrében, ennek okaival a következő fejezetben foglalkozom. 


\section{Számviteli rendszerek}

A világban szétnézve az egyes országok számviteli rendszerében számos különbséget figyelhetünk meg. Az eltérések több tényező együttes hatására vezethetőek vissza.

\subsection{A számviteli szabályozási rendszereket befolyásoló tényezök}

A számviteli szabályozási rendszerek kialakulását, a köztük lévő hasonlóságokat és különbségeket sokan vizsgálták az elmúlt évtizedekben. A kutatásokról részletesen olvashatunk többek között Nobes - Parker [2008], Haller - Walton [2003] müveiben.

A vizsgálatoknak különféle típusait lehet megfigyelni: ország tanulmányok, összehasonlító tanulmányok, a különbségek okainak elemzése, eltérő gyakorlatra vonatkozó klasszifikáció, számviteli harmonizáció értékelése.

A számviteli különbségek vizsgálata során számos - főként angol-szász - kutató a deduktív megközelítést alkalmazta és a környezeti ismérvek alapján végezte el az osztályozást. Ide sorolható többek között Mueller (1967, 1968), Nobes (1980, 1984, 1992), Gray (1988), Choi - Meek (2005) kutatása.

Az alábbi tényezők szerint került sor a vizsgálatokra:

- gazdasági / politikai / jogi rendszer;

- gazdasági fejlettség szintje / üzleti komplexitás foka / tőkepiac / vállalatfinanszírozás;

- befolyásolási övezetek (gyarmatosítás, megszállás);

- pénzügyi beszámolás célja;

- közzétett beszámolók felhasználói (érdekhordozók).

- adózási rendszer;

- számviteli standardok, számviteli szabályozás;

- számviteli szakma, oktatás, képzés, engedélyezés;

- szabályok alkalmazása és etika. 
A számviteli rendszerek eltérései okainak levezetését Haller - Walton a következő ábrán látható módon szemléltette.

4. ábra: A nemzetközi számviteli probléma okai

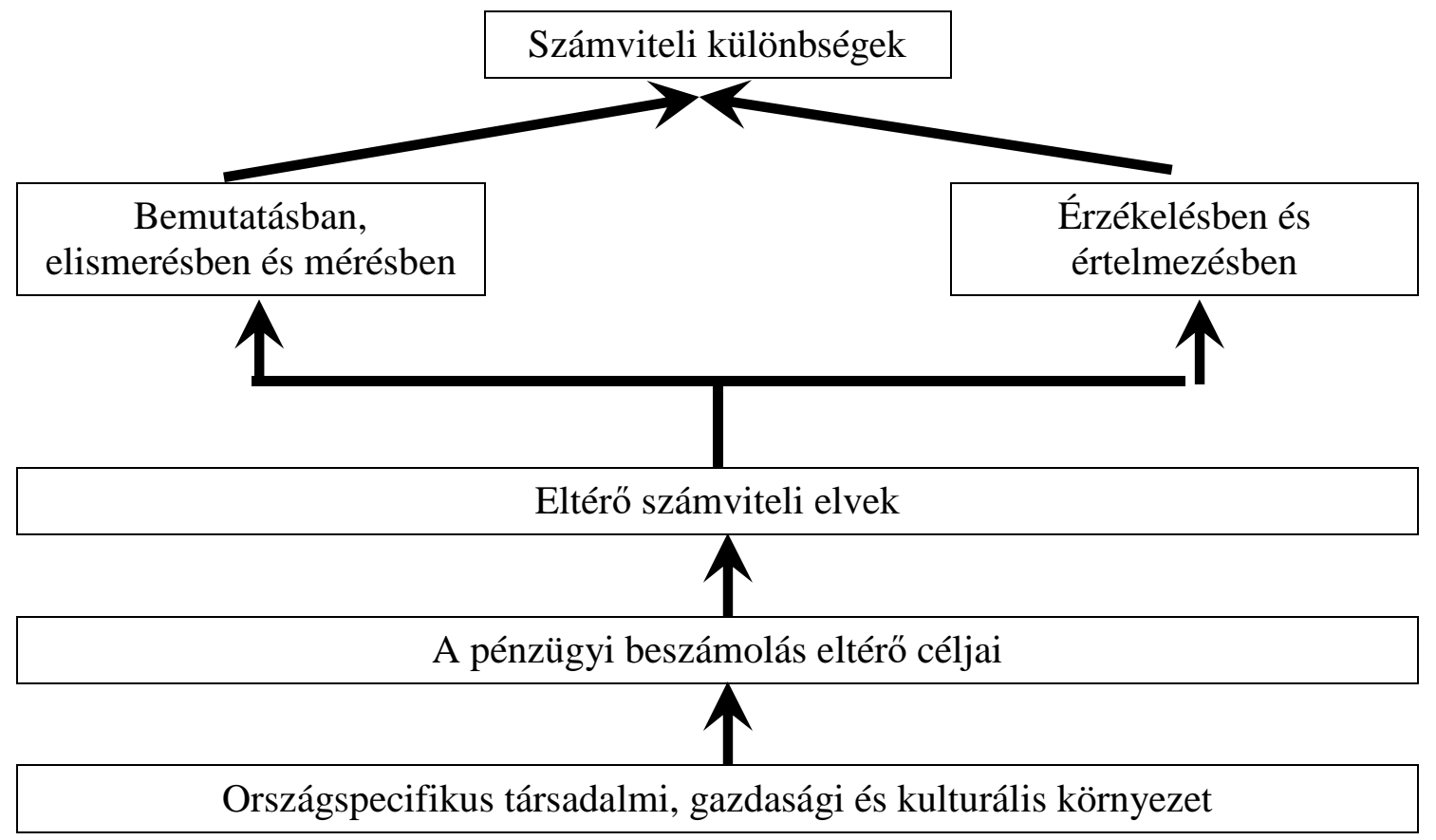

Forrás: Haller - Walton [2003] 2. oldal (saját fordítás)

Epstein-Mirza [2003] is hasonló okokkal magyarázza az eltérő számviteli rendszerek kialakulását, amely során azokat több szempont alapján helyezte el jellemzően a különbséget jól szemléltető példák, esetek segítségével.

- szabályozási környezet

(szabadelvüség, ,common low” - kodifikált jog)

- vállalkozás szabadsága

(kereskedelmi kultúra - szocialista gazdasági rendszer)

- infláció

(eredeti bekerülési ár - inflációkövető)

- gazdaság centralizáltságának foka

(korlátlanul szabad vállalkozás - állami ellenőrzés)

- gazdasági tevékenységek természete

(egyszerü agrárcég - komplex üzleti vállalkozások)

- gazdaság fejlettségi foka

(nincs külön definiálva) 
- gazdasági növekedés módja, üteme

(nincs külön definiálva)

Találhatunk azonban számos klasszikus statisztikai alapú, induktív vizsgálatot is, amelyek a számviteli rendszerek csoportosítását a szabályozásban alkalmazott konkrét megjelenítési és értékelési eljárások alapján végezték. Ide sorolhatjuk többek között Zeff (1972), Nobes (1984, 1998), Coopers \& Lybrand (1993), Ordelheide - KPMG (1995, 2001), Alexander - Archer (2001), D’Arcy (2001) kutatásait.

A számvitel Nobes és Parker által meghatározott definíciója szerint „A számvitel egy olyan módszertan, amelyet eltérö politikai, gazdasági és társadalmi környezetben gyakorolnak.” (Nobes - Parker [2008] 5. oldal), amely rámutat, hogy a különbségek okait magában a nemzeti sajátosságokban kell keresni. Kutatásai alapján Nobes és Parker [2008] az alábbi befolyásoló tényezőket tárta fel:

- kulturális különbségek;

- jogi berendezkedés;

- a vállalatfinanszírozás formája;

- adózás;

- egyéb külső hatások;

- számviteli szakma.

A következő fejezetekben ezeket a tényezőket vizsgálom meg részletesebben, bemutatva a területhez leginkább kötődő kutatások eredményeit. 


\subsubsection{Kulturális különbözőségek}

A kulturális különbözőségekből eredeztethető eltérések az élet számos területén megfigyelhetőek, nincs ez másképp a számviteli rendszereket tekintve sem.

A kulturális különbségek igazolására vonatkozó egyik legismertebb kutatás Hofstede (1980) nevéhez füződik, aki 39 országban 100000 IBM alkalmazottra kiterjedően végzett vizsgálatot, négy alapvető dimenzióra vonatkozóan:

- individualizmus versus kollektivizmus;

- nagy hatalmi távolság versus kis hatalmi távolság;

- erős szándék a bizonytalanság elkerülésére versus gyenge szándék a bizonytalanság elkerülésére;

- férfiasság versus nőiesség.

Ezen dimenziók mentén sikerült homogén csoportokat kialakítania és besorolnia az országokat. (Nobes - Parker [2008])

Ez adta az ötletet és az alapot Gray [1988] vizsgálatához, aki a számviteli rendszerek közötti különbségeket és hasonlóságokat kereste. A fenti dimenziók mintájára a számviteli szakemberek magatartására és a kialakult szabályozásra vonatkozóan állította fel saját rendszerét.

A következő párokat határozta meg:

- szakmai szabályozás versus jogszabályalkotói szabályozás;

- uniformalizáltság versus flexibilitás;

- konzervativizmus versus optimizmus;

- titokzatosság versus átláthatóság. 
Az egyes kategóriák az alábbi tartalommal bírnak.

Szakmai szabályozás (Profissionalism): a szabályozást független szakmai szervezetekre bízzák, amelyre nincs közvetlen befolyása az államnak.

Jogszabályalkotói szabályozás (Statutory control): a számviteli szabályozás közvetlenül az állam alá rendelt szerv/szervezet útján valósul meg.

Uniformalizált (Uniformity): a számviteli szabályozás részletekbe menően szabályoz, erős kontroll, nincs mozgástér, írott szabályozás.

Flexibilitás (Flexibility): a szabályozás elveket fektet le, alkalmazást a szakmára bízza.

Konzervativizmus (Conservatism): az óvatosság elvének hangsúlyozása, a kedvezőtlen kimenet megjelenítése a kimutatásokban. Módszere: az eszközök felértékelésének tilalma, várható veszteségek elszámolása, értékvesztések visszafordításának tiltása.

Optimizmus (Optimism): a valódiság elvének előtérbe helyezése az óvatosság rovására. A várható kedvező folyamatok, még nem realizált nyereségek beemelése a pénzügyi kimutatásokba. Módszere: bizonyos eszközök pozitív átértékelése, piaci értékre való árazás.

Titokzatosság (Secrecy): a számviteli kimutatásokban szereplő adatok jól körülhatároltak, többletinformációt a vállalkozások jellemzően nem szolgáltatnak, és ez nem is elvárt az adott környezetben.

Átláthatóság (Transparency): elvárás, hogy a vállalkozás minden jelentős tényről kimerítően tájékoztassa a közvéleményt, az adatok visszatartása csak korlátozott körben elfogadott.

A vizsgálat megállapította, hogy bizonyos tényezők között van összefüggés, egyrészt a szabályozási rendszer és a végrehajtás, másrészt a mérés és a közzététel mentén.

Szemléletessé teszi a kutatást, hogy az országok besorolásnak ábrázolására is lehetőség nyílik ezen dimenziók mentén. 
5. ábra: Gray-féle klasszifikáció a szabályozás és a végrehajtás dimenziójában

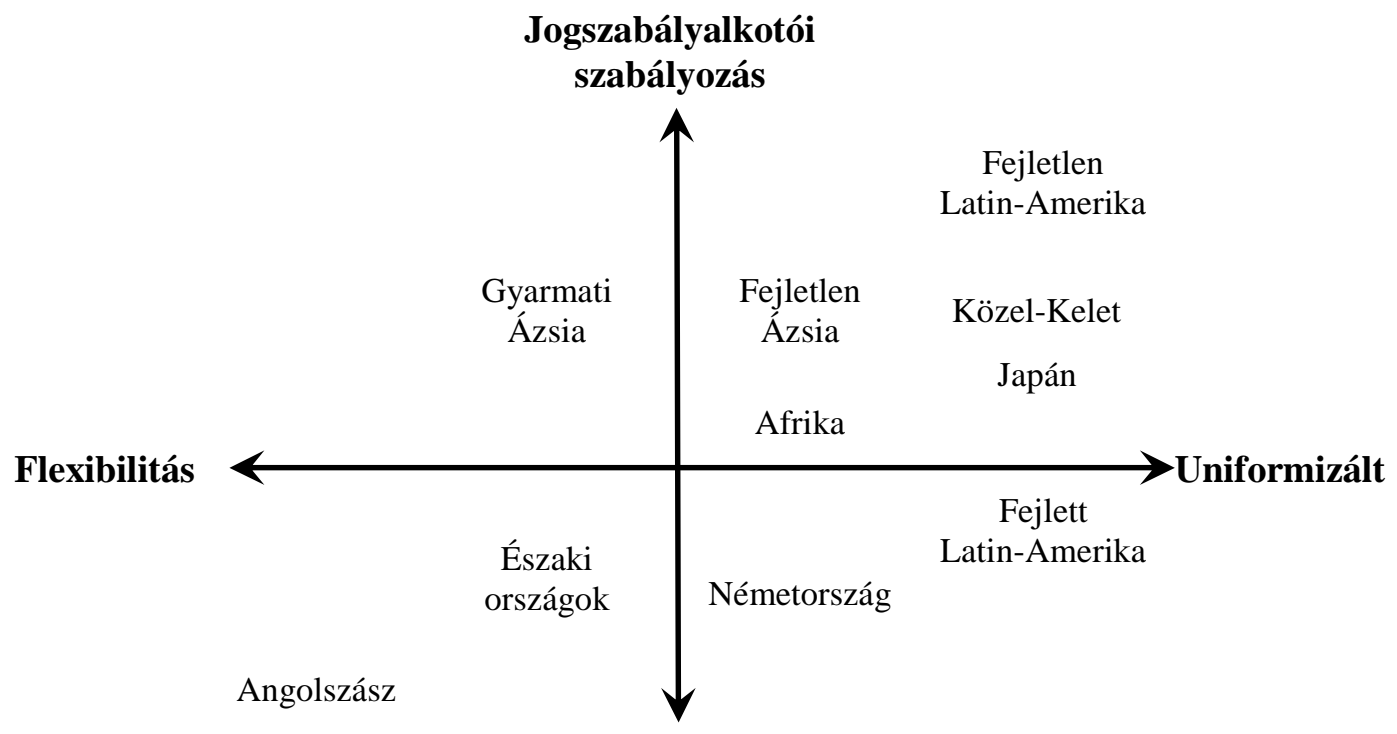

Szakmai szabályozás

Forrás: Gray [1988] 12. oldal

6. ábra: Gray-féle klasszifikáció a mérés és a közzététel dimenziójában

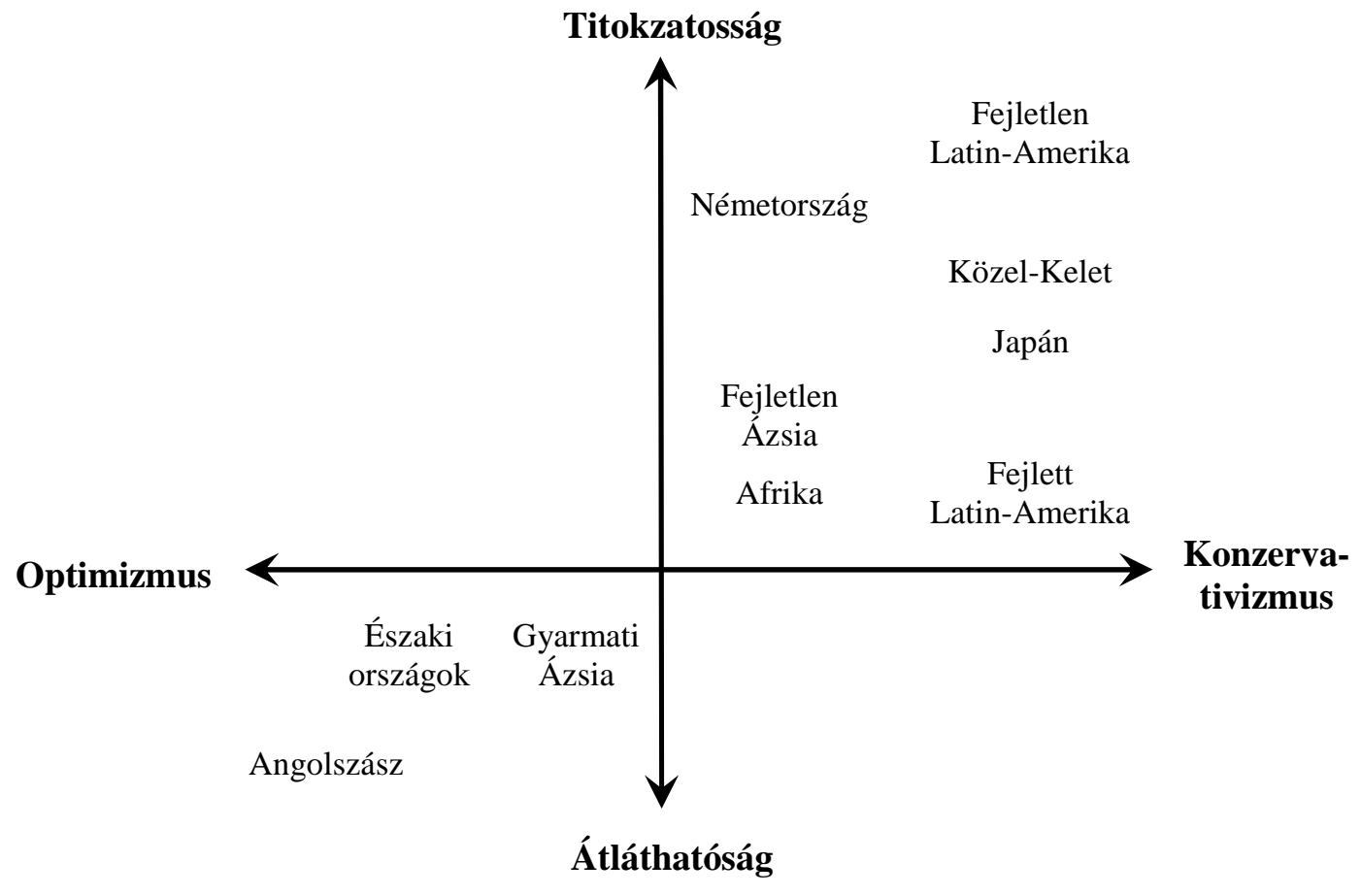

Forrás: Gray [1988] 13. oldal 


\subsubsection{Jogi berendezkedés}

A modern jogrendszernek két alapvető típusa van: a precedensjog (diszpozitív jogalkalmazás, szabadelvüség, common law) és a kodifikált jog (klasszikus római jogra épülő).

A precedensjogra épülő országoknál (elsősorban az angolszász országok tartoznak ide - Egyesült Királyság, Amerikai Egyesült Államok, Kanada, Ausztrália, Új-Zéland) a számviteli szabályokat lényegében a magánszektorban fejlesztették ki, nem a kormányzat fiskális politikájának érdekében. A jogalkotó alapvetően távol marad a konkrét számviteli szabályozástól, rábízza a számviteli szakmára, aki standardokon és ajánlásokon keresztül valósítja azt meg.

A kodifikált jogra épülö országokban (a kontinentális európai országok nagy része ide tartozik - Németország, Franciaország, Olaszország, Spanyolország, Portugália, Magyarország - valamint Japán) jogszabályokon keresztül valósul meg a számviteli szabályozás. Jellemzőek a kormányzatilag szankcionált, jelentős mértékben az adóügyi megfelelésre orientálódott számviteli és beszámolási szabályok.

A jogrendszer és a számvitel szabályozási formája között alapvetően együttmozgásról és nem egyértelmű megfeleltetésről van szó - kivételként említhető Hollandia példája, ahol a jogrendszer kodifikált jogon alapul a számvitel szabályozása azonban standardokra épülve a precedensjogra jellemző gyakorlatot követi.

A jogi rendszer természete hat a számviteli szabályokra és gyakorlatra, ugyanakkor például a nemzetközi számviteli standardok (IAS-IFRS) adoptálása egy adott országban tekintet nélkül a jogi berendezkedésre megvalósulhat. 


\subsubsection{A vállalatfinanszírozás formája}

A vállalkozások a modern gazdaságokban alapvetően két módon juthatnak forráshoz: tőzsdén / befektetőn vagy bankon / finanszírozó intézményen keresztül. Ebből az előbbi - a részvénykibocsátáson keresztüli finanszírozás - tulajdonosi kapcsolatot, az utóbbi - a pénzintézeti finanszírozás - hitelezői kapcsolatot létesít.

A kapcsolat típusa eltérő szabályozást kíván, hiszen más-más súllyal jelennek meg az egyes érdekhordózók a finanszírozási forma függvényében és a szabályozó ezt szem előtt tartva alakítja (alakíthatja) ki a számviteli rendszert.

Nobes és Parker az alábbi táblázatban foglalta össze a finanszírozási formával kapcsolatos meglátásait.

3. táblázat: Besorolás vállalati finanszírozás alapján

\begin{tabular}{|l|l|}
\hline \multicolumn{2}{|c|}{ A Piaci jellemzők } \\
\hline \multicolumn{2}{|c|}{ B } \\
\hline Erős részvénypiac & Gyenge részvénypiac \\
\hline Sok külső tulajdonos & Kis számú, bennfentes tulajdonos \\
\hline A könyvvizsgálói szakma jelentős & $\begin{array}{l}\text { A könyvvizsgálói szakma nem } \\
\text { jelentős }\end{array}$ \\
\hline $\begin{array}{l}\text { Adó és számviteli szabályok } \\
\text { elkülönültek }\end{array}$ & $\begin{array}{l}\text { Az adószabályok dominálnak a } \\
\text { számviteli szabályok felett }\end{array}$ \\
\hline \multicolumn{2}{|c|}{ Országok } \\
\hline Ausztrália & Franciaország \\
\hline Egyesült Királyság & Németország \\
\hline Amerikai Egyesült Államok & Olaszország \\
\hline
\end{tabular}

Forrás: Nobes-Parker [2008] 32. oldal-saját fordítás 
A témában végzett vizsgálatok közül érdemes még kiemelni Zysman (1983) empirikus kutatását, aki finanszírozási formákra vonatkozóan három csoportot különböztetett meg (Nobes - Parker [2008]):

- elsősorban tőzsdén keresztül finanszírozott gazdaság, ahol a befektetői érdekek kerülnek előtérbe (például Amerikai Egyesült Államok, Egyesült Királyság, Hollandia);

- döntően állami kölcsönökkel finanszírozott gazdaság, ahol egy speciális hitelezői érdek jelenik meg (például Franciaország, Japán);

- alapvetően bankon keresztül finanszírozott gazdaság, mely a hitelezői érdekek elsődlegességét testesíti meg (például Németország, Ausztria).

A befektetői szemléletű gazdaságban a pozitív jövőbeli várakozások integrálása jelenik meg a számviteli kimutatásokban, bátrabb helyzetértékeléssel dolgozik.

A hitelezői érdekeket elötérbe helyező szemlélet az óvatosság elvének térnyerését eredményezi, ezek a megközelítések jellemzően a legrosszabb helyzetet igyekeznek megjeleníteni a pénzügyi kimutatásokban, nem engedik a jövőbeli pozitív várakozások megjelenítését.

Az állami (hitelezői) szerepvállalással finanszírozott gazdaság is alapvetően az előző megfontoláson alapuló számviteli kimutatásokat kívánja meg, amely itt további speciális részletezésekkel egészül ki, amelyek kimondottam a speciális állami információigény kielégítését szolgálják.

A finanszírozási rendszer számvitelre gyakorolt hatását tekintve Beke [2010b] megállapította, hogy a belső tőkeellátású országokban (kevés számú külső részvénytulajdonos vesz részt a vállalat irányításában, a kontinentális országokra jellemző) gyakorlatilag nincs jelentős piaci igény az auditált és nyilvánosan közzétett számviteli beszámolókra, alapvetően a kormányzati és az (adó)hatósági igények dominanciája figyelhető meg. A külső (nem banki vagy kormányzati) tőkefinanszírozásban részesülő vállalkozások esetén (angolszász országok) erőteljesebb a számvitel piaci funkciója. Jól mutatja a két rendszer különbségét a rendszer által igényelt könyvvizsgálók száma. 


\subsubsection{Adózás}

Az állami információigény mértéke változatos képet mutat az államberendezkedés függvényében. Gondolva itt a szocialista tervgazdaságból kiindulva, ahol az állam mindenre kíváncsi (bár központban leginkább a termelési kvóták tervteljesítése és nem a vállalati gazdasági teljesítmény áll) egészen az alacsony állami befolyással működő gazdaságokra. El kell mondani azonban, hogy minden esetben megjelenik az állami információigény az adózással kapcsolatban.

Különbség figyelhető meg az egyes nemzetek között abban is, hogy a számviteli beszámolóban szereplő adatokat mennyire kell módosítani ahhoz, hogy az adót meg lehessen határozni.

Az angolszász országokban (pl. Egyesült Királyság, Amerikai Egyesült Államok) a számviteli beszámolóban lévő és az adónyilvántartásban lévő értékek eltérnek, a két nyilvántartás független egymástól.

A kontinentális Európában - például Németországban - alapvetően törekvés, hogy a két nyilvántartásban lévő adatok lényegében megegyezzenek.

A számvitel és adózás kapcsolatát számos tanulmány vizsgálta az elmúlt évek folyamán. A kutatások egyik iránya az országok adó és számviteli rendszerét összehasonlító, azok szorosságára irányuló vizsgálatok (ide tartozik többek között Hoogendoorn [2006], Lamb - Nobes - Roberts [1998]), a másik irány jellemzően egy ország rendszerének longitudinális vizsgálata (ide sorolható Haller [1992] Németországra, Artsberg [1996] Svédországra, Nobes - Schwencke [2006] Norvégiára vonatkozó kutatása). Az általam vizsgált területhez az országokat összehasonlító, a különbözőségek feltárására vonatkozó kutatások kapcsolódnak inkább, ezért a továbbiakban ezekkel foglalkozom részletesebben. 
Lambs et al. [1998] kutatásai a különbözö területeket, tranzakciókat vizsgálva öt minta szerint azonosítja az adózás és számvitel kapcsolatát.

4. táblázat: Az adózás és a számvitel kapcsolata - Lambs

\begin{tabular}{|l|l|l|}
\hline 1. & $\begin{array}{l}\text { Szétválasztás } \\
\text { (Disconnection) }\end{array}$ & $\begin{array}{l}\text { Eltérő az adózás és a számvitel szabályozás azok } \\
\text { eltérő céljainak megfelelöen }\end{array}$ \\
\hline 2. & $\begin{array}{l}\text { Azonosság } \\
\text { (Identity) }\end{array}$ & $\begin{array}{l}\text { Azonosság az adózási és a számviteli szabályok } \\
\text { között }\end{array}$ \\
\hline 3. & $\begin{array}{l}\text { Számvitel vezet } \\
\text { (Accounting lead) }\end{array}$ & $\begin{array}{l}\text { Egy számviteli szabály (vagy választási lehetőség) } \\
\text { egy az egyben alkalmazható az adózásban is } \\
\text { (jellemzően speciális adószabály hiányában) }\end{array}$ \\
\hline 4. & $\begin{array}{l}\text { Adó vezet } \\
\text { (Tax leads) }\end{array}$ & $\begin{array}{l}\text { Az adózási szabály szerinti elszámolás kiterjed a } \\
\text { számvitelre is (jellemzően speciális számviteli } \\
\text { szabályozás hiánya miatt) }\end{array}$ \\
\hline 5. & $\begin{array}{l}\text { Adó dominál } \\
\text { (Tax dominates) }\end{array}$ & A számviteli szabályt az adószabály felülírja \\
\hline
\end{tabular}

Forrás: Lambs et al. [1998] 174. oldal alapján saját szerkesztés

Négy országot (Egyesült Királyság, Amerikai Egyesült Államok, Franciaország és Németország) és 18 számviteli területet (például értékcsökkenés, lízing, kutatási és fejlesztési költségek, készlet értékelés, hosszú távú szerződések, kamatráfordítások) vizsgálva arra a következtetésre jutottak, hogy az angolszász országokban a függetlenség (szétválasztás - 1. kategória) dominál (Egyesült Királyságban 12/18, az Amerikai Egyesült Államokban 11,5/18 esetben), míg Franciaországban (12,5/18) és még inkább Németországban (16/18) a függőség különböző esetei (2-5. kategória) voltak a jellemzőek. 
A függetlenség és függőség időbeli alakulását vizsgálva Hoogendoorn [1996] megállapította, hogy általánosan megfigyelhető tendencia az adózás és a számvitel függetlenedése, ugyanakkor az országok egyértelmű kategóriákba sorolhatóak.

5. táblázat: Az adózás és a számvitel kapcsolata - Hoogendoorn

\begin{tabular}{|c|l|l|}
\hline 1. & $\begin{array}{l}\text { Függőségi rendszer, nem várható változás } \\
\text { (az adó az egyedi és csoport szinten is hatással van) }\end{array}$ & $\begin{array}{l}\text { Belgium, } \\
\text { Olaszország }\end{array}$ \\
\hline 2. & $\begin{array}{l}\text { Függőségi rendszer, nem várható változás } \\
\text { (az adónak nincs hatása csoport szinten) }\end{array}$ & $\begin{array}{l}\text { Franciaország, } \\
\text { Németország }\end{array}$ \\
\hline 3 & $\begin{array}{l}\text { Függőségi rendszer (még), de egyértelmüen } \\
\text { megfigyelhető a függetlenség irányába való } \\
\text { elmozdulás }\end{array}$ & $\begin{array}{l}\text { Finnország, } \\
\text { Svédország }\end{array}$ \\
\hline 4 & $\begin{array}{l}\text { Formálisan független adó és számvitel, } \\
\text { de a gyakorlatban megfigyelhető a kapcsolat }\end{array}$ & $\begin{array}{l}\text { Csehország } \\
\text { Lengyelország }\end{array}$ \\
\hline 5 & $\begin{array}{l}\text { Független rendszerek } \\
\text { (halaszott adó szabályozás több alternatívával) }\end{array}$ & Dánia \\
\hline 6 & $\begin{array}{l}\text { Független rendszerek } \\
\text { (speciális halasztott adó szabályozással, } \\
\text { részleges adó megosztás) }\end{array}$ & $\begin{array}{l}\text { Egyesült Királyság } \\
\text { Irország }\end{array}$ \\
\hline 7. & $\begin{array}{l}\text { Független rendszerek } \\
\text { (speciális halasztott adó szabályozás, } \\
\text { az átértékelés halasztott adó hatását elismeri) }\end{array}$ & $\begin{array}{l}\text { Hollandia, } \\
\text { Norvégia }\end{array}$ \\
\hline
\end{tabular}

Forrás: Hoogendoorn [1996] 793. oldal alapján saját szerkesztés

A négy kiemelt terület mellett természetesen egyéb hatások is érvényesülnek és befolyással bírnak a számviteli rendszerekre, ezáltal azok különbözőségét vagy éppen hasonlóságát okozzák. 


\subsection{A számviteli rendszerek klasszifikációja}

A számviteli rendszerek különbözőségét befolyásoló tényezők áttekintése után, komplex rendszerbe állítva azokat, lehetôség nyílik az országok csoportosítására.

Több neves kutatás is foglalkozott a számviteli rendszerek klasszifikációjával, ezekből a Mueller féle tipológiával és Nobes nevéhez kötődő hierachikus rendszer bemutatásával foglalkozom részletesebben.

Mueller (1967) direkt módszert alkalmazva 4 csoportra bontotta az országokat a számvitel célja szerint (Nobes [2008]):

- Makro szemléletü országok: a számvitel elsősorban gazdaságpolitikai célokat szolgál, szoros összefüggés az adózási szabályokkal, hitelezői védelem, óvatosság elve, részletes, leíró jogszabályok (például Svédország).

- Mikro szemléletü országok: a magánvállalkozások érdekein alapul a számvitel, a beszámoló elválik az adóbevallástól, befektetői érdekek védelme dominál (például Hollandia).

- Pragmatikus szemléletü országok: a gyakorlatot alárendelik az elméletnek, a szakma szerepe nagy a szabályozásban, keret jellegü jogszabályok, befektetői védelem dominál, nyilvánosság kiemelt szerepe (például Egyesült Királyság).

- Uniformizált szemléletủ országok: nagy az állam adminisztratív kontrollja a vállalkozásokon, jelentős bürokratikus rendszer, részletes szabályozás, a szakmai szervezetek szabályozó szerepe csekély, hitelezői védelem (például Franciaország, Németország).

A kategóriák nem egymást kizáró volta miatt besorolási problémák voltak, ami a rendszer továbbfejlesztéséhez vezetett. Alternatív csoportképző ismérvek (gazdasági fejlettség foka, üzleti környezet bonyolultsága, politikai jellemzők, jogi környezet) figyelembe vételével 10 jól elkülöníthető ország-csoport volt meghatározható. 
Nobes nem csak csoportokat képzett, hanem hierarchikus rendszerbe is foglalta az országokat. Kilenc faktor mentén végezte el a besorolást (Nobes - Parker [2008] 65. oldal):

1. A tőzsdei cégek közzétett beszámolóinak felhasználói.

2. A használt törvény vagy standard elöírásainak alkalmazásának a foka.

3. Az adózási szabályok fontossága.

4. Konzervativizmus/óvatosság.

5. A historikus költségek szigorú alkalmazása.

6. Költségek átcsoportosításának lehetősége.

7. Konszolidálási eljárások.

8. Tartalékképzési lehetőségek.

9. A szabályok alkalmazásának egységessége.

A következő oldalon lévő ábra szemlélteti a csoportosítás végeredményét.

Az eredeti (még 1980-ban készült) csoportosítás az eltelt 30 év alatt többször frissítésre került. Az 1998-as csoportosításnál Nobes a tőkepiac szerepét kiemelve végezte el a besorolást, illetve új elemként megjelent az IFRS.

Erős tőkepiaci kategóriába sorolta Hollandiát valamint az angolszász országokat, Egyesült Királyságot és Amerikai Egyesült Államokat (e kettő közzé került az IFRS). Gyenge tőkepiacú csoportba 3 kategóriát alakított ki Nobes, amelyekbe Belgium Franciaország, Németország - Olaszország, illetve Japán került besorolásra. 
7. ábra: Számviteli rendszerek hierarchikus csoportosítása (Nobes, 1980)

Számviteli rendszerek (1980)

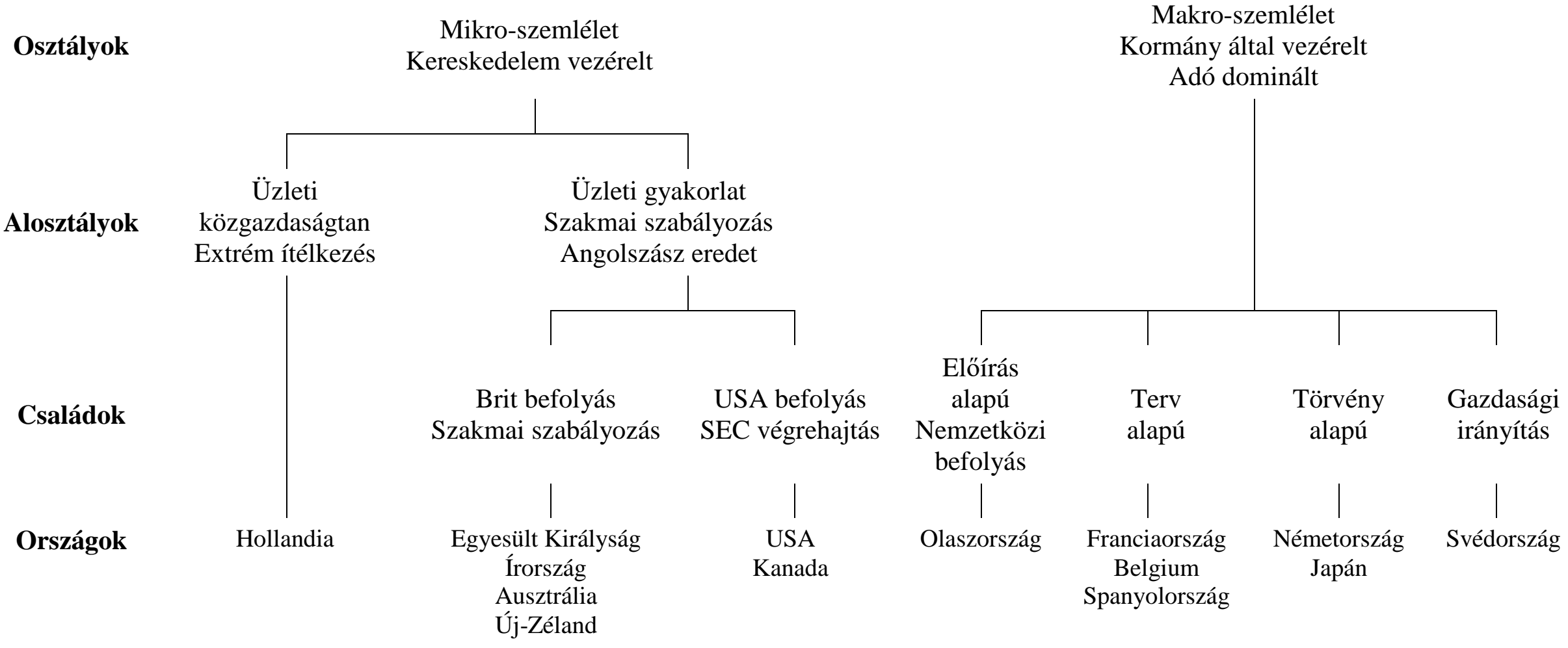

Forrás: Nobes - Parker [2008] 65. oldal vagy Nobes [2011] 25. oldal (saját fordítás) 
Az alkalmazott számviteli gyakorlatok közötti eltérésekben Nobes [2011] szerint két tényező játszik szerepet: az egyes országok eltérő számviteli szabályrendszere és az adott országban kialakult számviteli gyakorlat. Korábban a két hatás szétválasztására nem volt lehetőség, de az IFRS-ek elterjedésével új dimenziója nyílt a vizsgálatoknak. Az Európai Unióban 2005-től a tőzsdei konszolidált beszámolókat kötelező az IFRS-ek szerint készíteni, tehát a szabályrendszer azonos, a különbséget kizárólag az egyes országokban alkalmazott számviteli gyakorlat közötti eltérés okozhatja. A kutatásban 8 ország (Ausztrália, Egyesült Királyság, Franciaország, Hollandia, Németország, Olaszország, Spanyolország, Svédország) 271 vállalatának beszámolóját vizsgálta Nobes 13 szempont szerint (6 megjelenési és 7 mérési kritérium alapján). Többváltozós statisztikai módszerekkel végrehajtott elemzés alapján megállapította, hogy az azonos szabályrendszer alkalmazása ellenére léteznek különbségek az alkalmazott gyakorlatban. Három csoportot tudott beazonosítani:

- kontinentális európaiak: Franciaország, Hollandia, Németország, Olaszország és Spanyolország;

- angolszászok: Ausztrália és Egyesült Királyság;

- kilógó eset: Svédország.

A klaszterelemzés dendrogramja jól szemlélteti a kapott eredményt

8. ábra: IFRS-t alkalmazó országok számviteli gyakorlatának összehasonlítása

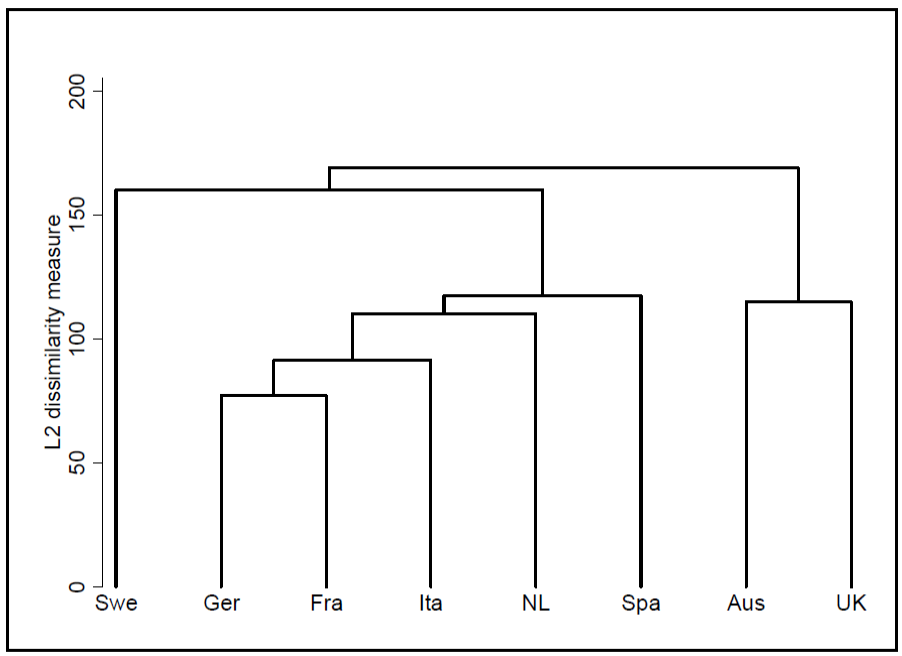

Forrás: Nobes [2011] 28. oldal 


\section{Számviteli harmonizáció}

A globalizáció és az IFRS-ek elterjedésével ${ }^{5}$ a nemzeti számviteli szabályozásban is megfigyelhetjük az nemzetközi standardokhoz való közeledést, konvergenciát, ezért a pénzügyi beszámolás szabályozása egyre közelebb kerül egymáshoz az egyes országokban.

A harmonizációs folyamatok megfigyelésre jó lehetőséget teremt a kutatásokban megfigyelhető új irányzat, amely a különféle számviteli rendszerek hasonlóságát az IAS/IFRS-hez mint benchmarkhoz mért távolsággal jellemzi. Beke [2010a] az általa készített elemzésében két csoportra bontva (20 EU-n belüli és 29 EU-n kívüli ország) vizsgálta a nemzeti számviteli szabályok eltéréseit a nemzetközi standardoktól. A vizsgálat Bae - Tan - Welker adatbázisán alapul, amelyben 21 szempont szerint vizsgálták az egyes országok IAS/IFRS-ekkel való összhangját bináris értékeléssel ${ }^{6}$, ez kerület kiegészítésre a hazai számviteli standardadaptációs gyakorlat tapasztalataival. Beke 16 kiválasztott IAS/IFRS- $\mathrm{t}^{7}$ figyelembe véve a standardok összehangoltságára adott bináris értékek átlagaként definiálta az országok nemzeti számviteli szabályozásának eltérését az IAS/IFRS-ektől. Az eredményeket a 9. és a 10. ábra szemlélteti.

Az összehasonlítás alapján az angolszász országok számviteli rendszere közelebb áll az IAS/IFRS-ekhez, míg a kontinentális európai (kivétel Hollandia), számviteli szabályozása jelentősebb különbséget mutat attól. Ennek magyarázata az eltérő jogrendszerben is keresendő, hiszen a római jog elvein alapuló, törvények formájában szabályozó jogi környezetben nehezebb és hosszabb időt vesz igénybe a standardok adaptációja (Magyarország is ebbe a körbe tartozik).

\footnotetext{
${ }^{5}$ Sok országban a tőzsdei cégek konszolidált beszámolójukat az IFRS-ek alapján kötelező elkészíteniük. Lásd részletesen a II.1.1.2. fejezetben.

${ }^{6} 0$ : összhangban van a nemzeti szabályozás a nemzetközi standarddal, 1: nincs összhang közöttük

${ }^{7}$ IAS $1,2,7,8,12,14,17,19,24,27,36,37,38$ és IFRS 3, 5, 7
} 
9. ábra: Nemzeti számviteli szabályok eltérései az EU-n belül

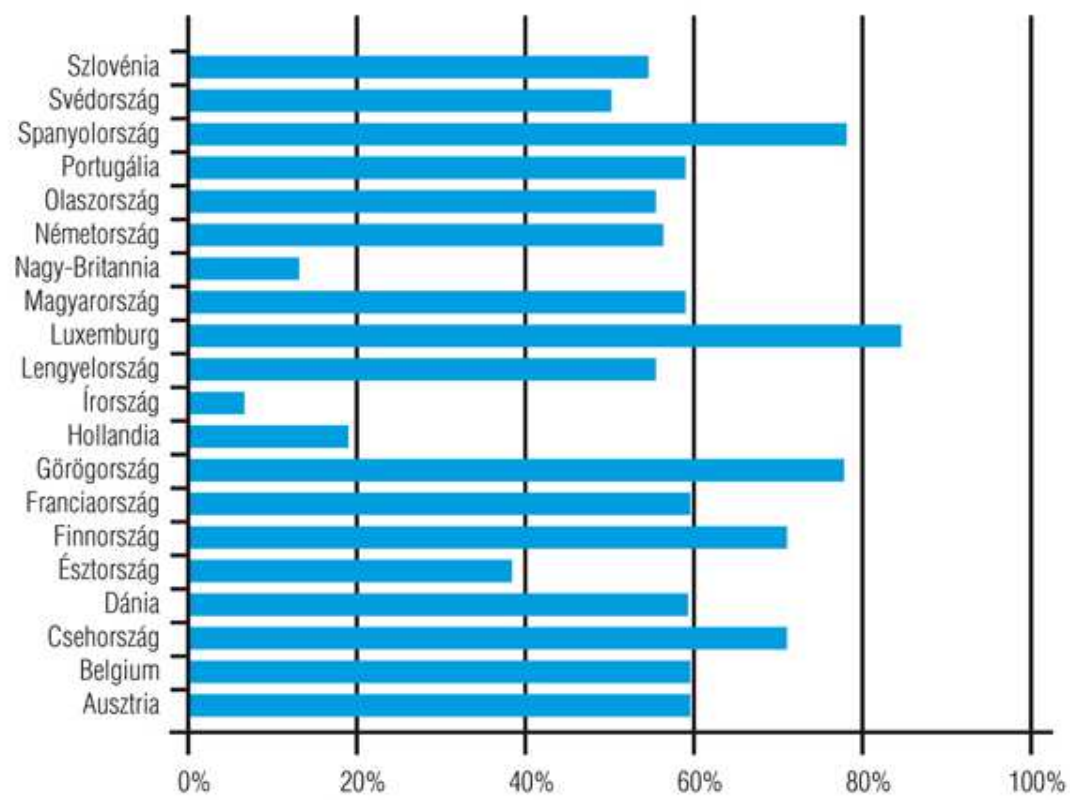

Forrás: Beke [2010a] 91. oldal

10. ábra: Nemzeti számviteli szabályok eltérései az EU-n kívül

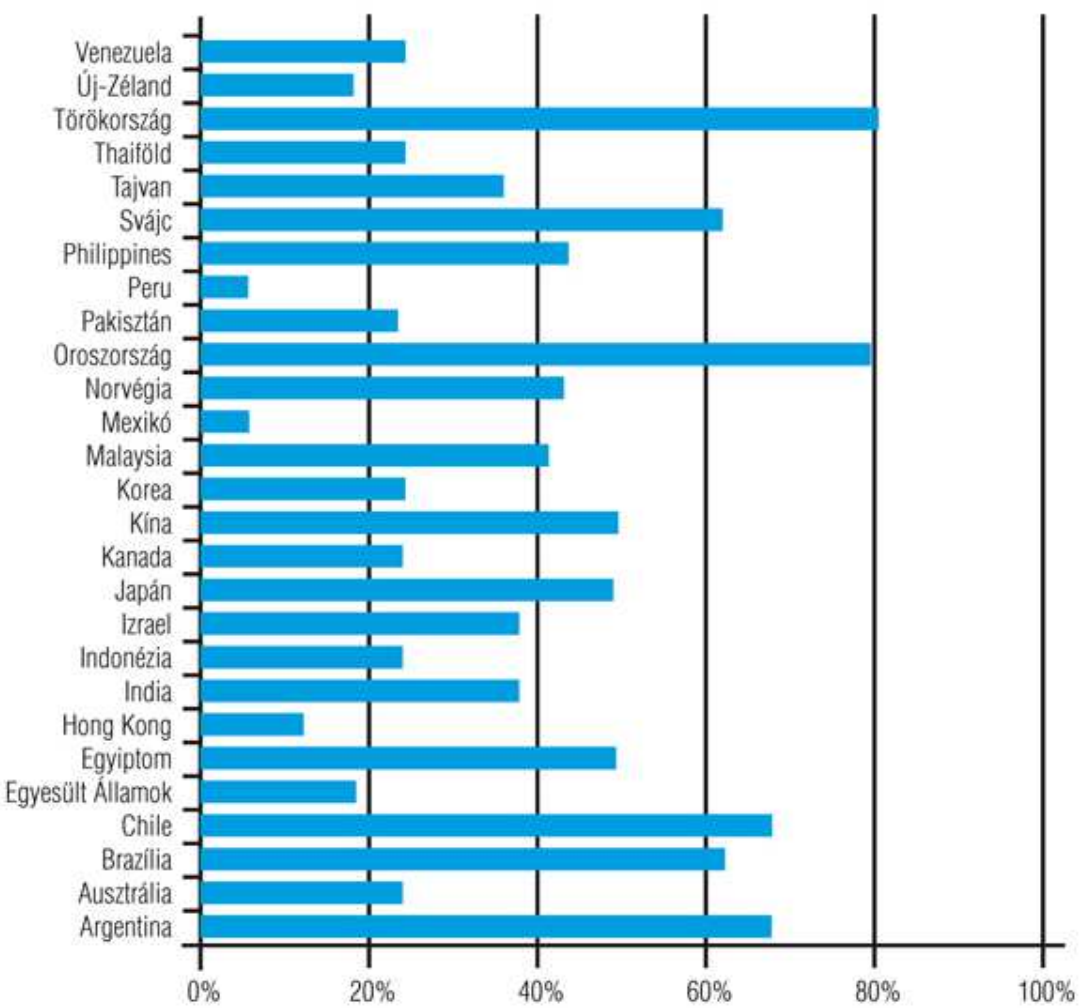

Forrás: Beke [2010a] 93. oldal 
Az Európai Unión kívüli országok esetén elmondható, hogy a dél-amerikai (kivétel Peru) országok a latin elveket követik, az eltérés mértéke is hasonló mértékü (65\%) mint az uniós mediterrán térség országaiban. Az ázsiai országok számvitelében a hajdani gyarmatosítók hatása mutatható ki, például Hong Kongban, Indiában az angolszász számviteli szemlélet érvényesül. Megállapítható, hogy Oroszország és Törökország számviteli szabályozása jelentősebb eltérést mutat a nemzetközi standardoktól.

El kell mondani ugyanakkor, hogy bár megfigyelhető a közeledés a számviteli rendszerek között, számos tényező akadályozhatja, lassíthatja a folyamatot, amelyek alapvetően a befogadó országok eltérő gazdasági, jogi, társadalmi, kulturális környezetéből adódnak. Kazainé [2010] az alábbi tényezőket azonosította be:

- azokban az országokban, ahol a pénzügyi jelentés adócélokat is szolgál, az adózási rendszerrel való kapcsolat megteremtése különösen nagy figyelmet igényel;

- az általános jogi környezetbe való beillesztés, a társasági joggal való összhang megteremtése;

- nacionalizmus hatása, ellenérzés más ország normáinak elfogadásával kapcsolatban;

- szakmai ellenállás, a megszokott szabályokhoz való ragaszkodás;

- a nemzeti szabályozó szervek (hatóságok vagy szakmai csoportok) kockázatot látnak abban, ha egy tőlük független szervezet alkotja meg helyettük a számviteli elöírásokat, amely nem veszi figyelembe a fennálló különbségeket a jogi és gazdasági környezetben;

- nem elegendő az egyszerű átvétel, bizonyos esetekben az egész beszámolási struktúra átalakításával jár;

- kritikaként jelenik meg az IFRS-ek bonyolult volta, a sok kivétel, alternatíva;

- magas átállási költségek, oktatás.

A globalizáció, a multinacionális vállalkozások által teremtett igény az országoktól független számviteli szabályokra egyre erőteljesebben jelen van, ugyanakkor a harmonizációval ellentétes hatások érvényesülése is megfigyelhető. A szabályozási eltérések megszűntetése az okok sokszínűsége és összetettsége miatt nem egyszerü feladat. 
11. ábra: A globális szabályozásra ható tényezőcsoportok
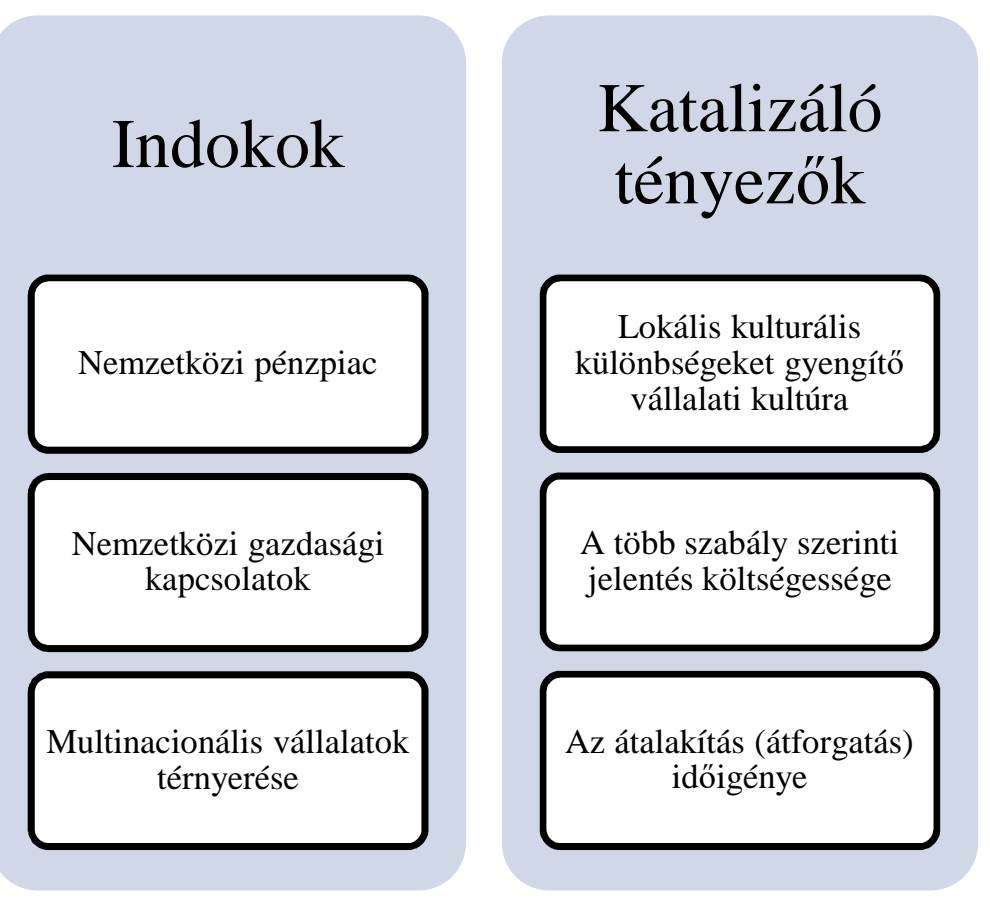

\section{Ellentényezők}

(Még mindig) markáns különbségek a

finanszíroszás formájában

Betartatás nehézsége

Szabályozási

"nacionalizmus"

Múltfüggés

Forrás: Lakatos [2014] 10. oldal

A vizsgálatokból megállapítható, hogy a harmonizáció folyamata megindult és határozott léptekkel halad, azonban az akadályozó tényezők miatt nehéz megjósolni meddig tart az út. 


\section{A SZÁMVITEL SZABÁLYOZÁSA}

Ahhoz, hogy egy vállalkozás pénzügyi kimutatásainak tartalmát, a közölt információkat értelmezhessük elkerülhetetlen, hogy szemügyre vegyük azokat a jogi aktusokat, amelyek a vállalkozás közvetlen müködési környezetének egyik összetevőjét adják. Szükséges tehát a szabályozó rendszer ismerete, ezért az alábbiakban ezt tekintem át egyrészt nemzetközi (IFRS-ek, illetve az Európai Uniós irányelvek), másrészt nemzeti (esetünkben magyar számviteli törvény) vonatkozásban.

\section{Szabályozási szintek}

A számvitel szabályozása több szinten történhet. Lakatos [2014] két kategóriát különböztet meg nemzeti és nemzetek fölött álló (nemzetközi szabályozás) szintet.

Fogalmai szerint az előbbi, nemzeti szint

„a számviteli szabályok és e szabályozás megalkotásával, módosításával, valamint betartásával szorosan összefüggö intézmények olyan összessége, amelyek csak az adott nemzeti keretek között elfogadottak, legitimek és kikényszerithetöek”,

míg az utóbbi, tehát a nemzetközi szint

„a számviteli szabályok és e szabályozás megalkotásával, módosításával, valamint betartásával szorosan összefüggö intézmények olyan összessége, amelyek nemcsak nemzeti keretek között elfogadottak, legitimek és kikényszeríthetöek, hanem azok egységes módon alkalmazandók több nemzet területén is, és a lefedett terület világgazdasági szempontból meghatározó jelentőségü”. Lakatos [2014] 5. oldal

A nemzeti szabályozás a legtöbb ország esetén megfigyelhető. Ez a szint magán hordozza a helyi sajátosságokat, amelyek a korábban már vizsgált befolyásoló tényezők miatt a számviteli rendszerek különbözőségéhez vezet. 
Egy adott ország szabályrendszerén belül esetlegesen megjelenő ágazati számviteli szabályozás (pl. hitelintézet, mezőgazdaság) egy-egy területre vonatkozóan tartalmaz speciális részletszabályokat, de jellemzően nem tekinthetőek különálló szabályozási szintnek.

A nemzeti szint fölötti számviteli szabályozási rendszerek több országra vonatkozó egységes alkalmazása globális (az IFRS-ek rendszere), illetve regionális (pl. EU irányelvek) viszonylatban jelenhet meg.

A magyar számviteli jogrend hierarchiáját mutatja be a következő ábra, amely tükrözi a különféle szabályozási szintek megjelenését és egymásra gyakorolt hatását.

12. ábra: A magyar számviteli jogrend hierarchiája

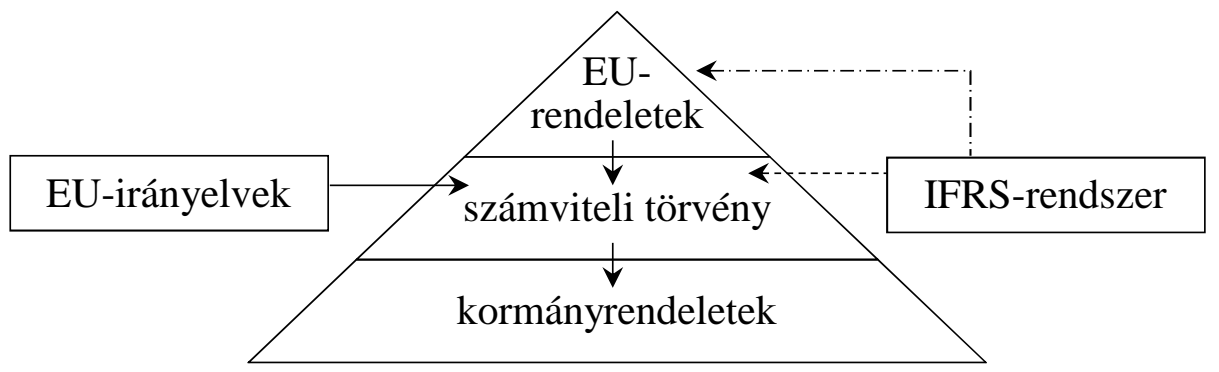

Forrás: Tóth [2012] 4. oldal alapján saját szerkesztés

A továbbiakban áttekintjük a számviteli szabályozás nemzetközi szintjét az IFRS rendszer és az Európai Uniós irányelveken keresztül, majd a nemzeti szintet a magyar számviteli törvény tükrében. 


\subsection{Nemzetközi számviteli szabályozási szint-IFRS rendszer}

Az egyik legismertebb és legelterjedtebb nemzetközi számviteli szabályrendszer az IFRS-ek rendszere. Ennek kialakulását és elterjedését tekintem át az alábbiakban.

\subsubsection{A nemzetközi pénzügyi beszámolási rendszer fejlődéstörténete}

A Nemzetközi Számviteli Standardok Bizottságot (IASC) 1973. június 23-án hozta létre tíz ország (Amerikai Egyesült Államok, Ausztrália, Egyesült Királyság, Hollandia, Írország, Japán, Kanada, Franciaország, Mexikó, Németország), hogy egységes Nemzetközi Számviteli Standardokat (IAS) alkossanak, s ezzel növeljék az egyes beszámolók összehasoníthatóságát. A bizottság 2001-től átalakulva Nemzetközi Számviteli Standard Testület (IASB) néven folytatja tevékenységét, s azóta Nemzetközi Pénzügyi Beszámolási Standardokat (IFRS) bocsát ki. A standardok gyakorlati megvalósítását értelmezések kiadásával is segítik (SIC, IFRIC).

A nemzetközi standardalkotási folyamatot Bosnyák [2011] a következő szakaszokra bontja:

1. szakasz (1973-1989):

a jelentősebb számviteli kérdésekre vonatkozó standardok elfogadása. A világ vezető országaiban alkalmazott számviteli megoldások egybegyüjtése, így egy kérdésre több válaszlehetőséget is kínálva, mintegy „legkisebb közös nevező” létrehozása. IASC legitimációjának erősítése.

2. szakasz (1990-1995):

a pénzügyi beszámolók jobb összehasonlíthatóságának érdekében a választási lehetőségek szükítése.

3. szakasz (1995-2000):

központi mag (,alapstandard sorozat”) létrehozása az IOSCO-val együttmüködve. Azon standardok felülvizsgálata, amelyek a nemzetközi tőkemozgásokban 
érintettek, a nemzetközi tőkepiacokon szereplő vállalatok pénzügyi beszámolóihoz szükségesek.

\section{4. szakasz (2001-2004):}

az IAS/IFRS-ek és a nemzeti szabályozások összehangolására vonatkozó törekvések, globális standardok kibocsátása és alkalmazásuknak az elősegítése. Konvergencia program, IASB és FASB közös fejlesztések.

\section{5. szakasz (2005-):}

alapvető cél egy globális pénzügyi beszámolási infrastruktúra kifejlesztése, amely magába foglalja a vállalatirányítási gyakorlatot, konzisztens és átfogó számviteli standardokat, a könyvvizsgálói gyakorlatot, illetve az átfogó felügyeleti rendszert.

Természetesen a standardok folyamatos fejlesztése, s újabbak kiadása mindegyik szakaszban megtalálható. Jelenleg (2017-ben) 29 IAS és 13 IFRS kötelezően hatályos (előalkalmazások nélkül számítva).

A nemzetközi pénzügyi beszámolási standardok fejlődésének részletesebb leírása Epstein - Mirza [2003], Zeff [2012] müveiben található.

A konkrét standardok bemutatása meghaladja a disszertáció kereteit, illetve a vizsgált területhez nem kapcsolódik szervesen, ezért attól eltekintek (megtalálható Epstein - Mirza [2003], IASCF [2003], Lakatos et. al. [2013] múveiben, illetve megtekinthető az IASB honlapján).

\subsubsection{A nemzetközi pénzügyi beszámolási rendszer alkalmazása}

Az IAS/IFRS-ek megjelenése az egyes országok számviteli jogrendjében többféleképp is megvalósulhat:

- áttérés az IAS/IFRS-ek használatára, teljes befogadás, kötelező alkalmazás;

- az adott ország nemzeti számviteli szabályainak összehangolása az IAS/IFRSekkel, engedélyezve azok alkalmazását, alternatív megoldásként;

- nem engedélyezett az alkalmazás. 
A nemzetközi pénzügyi beszámolási rendszer alkalmazása legnagyobb mértékben a tőzsdén jegyzett vállalkozásoknál valósult meg. A következő táblázatok az elterjedtség szintjének és módjának bemutatása mellett szemléltetik, hogy jelenleg is bővül az alkalmazó országok száma, illetve kötelező alkalmazás irányába halad a folyamat.

6. táblázat: Az IAS/IFRS-ek használata a világon (tőzsdei)

\begin{tabular}{|l|r|r|r|r|r|r|}
\hline \multirow{2}{*}{$\begin{array}{l}\text { IRFS-ek alkalmazása } \\
\text { tőzsdei vállalatoknál }\end{array}$} & \multicolumn{2}{|c|}{2013} & \multicolumn{2}{|c|}{2017} & \multicolumn{2}{c|}{ Változás } \\
\cline { 2 - 8 } & ország & arány & ország & arány & ország & arány \\
\hline Kötelező & 93 & $60,8 \%$ & 96 & $62,3 \%$ & 3 & $1,5 \%$ \\
\hline Részben kötelező & 6 & $3,9 \%$ & 10 & $6,5 \%$ & 4 & $2,6 \%$ \\
\hline Engedélyezett & 24 & $15,7 \%$ & 25 & $16,2 \%$ & 1 & $0,5 \%$ \\
\hline Nem engedélyezett & 30 & $19,6 \%$ & 23 & $14,9 \%$ & -7 & $-4,7 \%$ \\
\hline Összesen & 153 & $100,0 \%$ & 154 & $100,0 \%$ & 1 & $0,0 \%$ \\
\hline Megjegyzés & \multicolumn{2}{|c|}{ nincs tőzsde 21} & \multicolumn{2}{|c|}{ nincs tőzsde 21} & \multicolumn{2}{|c}{-} \\
\hline
\end{tabular}

Forrás: Use of IFRSs by Jurisdiction (www.iasplus.com) alapján saját szerkesztés

A nem tőzsdei cégek esetében ez a tendencia még erőteljesebben érvényesül, egyre szükül azon nemzetek száma, ahol nem engedélyezett az alkalmazás.

7. táblázat: Az IAS/IFRS-ek használata a világon (nem tőzsdei)

\begin{tabular}{|l|r|r|r|r|r|r|}
\hline $\begin{array}{c}\text { IRFS-ek alkalmazása } \\
\text { nem tőzsdei } \\
\text { vállalatoknál }\end{array}$ & \multicolumn{2}{|c|}{2013} & \multicolumn{2}{c|}{2017} & \multicolumn{2}{c|}{ Változás } \\
\cline { 2 - 8 } & ország & arány & ország & arány & ország & arány \\
\hline Kötelező & 25 & $18,5 \%$ & 28 & $19,6 \%$ & 3 & $1,1 \%$ \\
\hline Részben kötelező & 30 & $22,2 \%$ & 38 & $26,6 \%$ & 8 & $4,4 \%$ \\
\hline Engedélyezett & 44 & $32,6 \%$ & 47 & $32,9 \%$ & 3 & $0,3 \%$ \\
\hline Nem engedélyezett & 36 & $26,7 \%$ & 30 & $21,0 \%$ & -6 & $-5,7 \%$ \\
\hline Összesen & 135 & $100,0 \%$ & 143 & $100,0 \%$ & 8 & $0,0 \%$ \\
\hline Megjegyzés & nincs információ 39 & nincs információ 32 & -7 & \\
\hline
\end{tabular}

Forrás: Use of IFRSs by Jurisdiction (www.iasplus.com) alapján saját szerkesztés

Sok szabályozásban eltérést tapasztalhatunk az IAS/IFRS-ek alkalmazhatóságát illetően a beszámolók átfogása tekintetében: a konszolidált beszámolókban gyakrabban 
(pl. az Európai Unióban 2005-től kezdődően a tőzsdei vállalatok a konszolidált beszámolójukat kötelesek az IFRS elöírásainak megfelelően készíteni), míg az egyediekben ritkábban engedik a nemzeti szabályoktól való eltérést. Ennek egyik fő oka, hogy ez utóbbi sok esetben a társasági nyereségadó meghatározásának alapjául is szolgál.

Ezt az Európai Bizottság 2010-es felmérése (Sipos [2010]) is alátámasztja, amely szerint a tőzsdei konszolidált beszámolóknál minden tagállamban megvalósult az IAS/IFRS-ek alkalmazása, azonban e körön kívül már nem ennyire egységes a kép.

8. táblázat: Az IAS/IFRS-ek használata az EU-ban (2010)

\begin{tabular}{|l|r|r|r|r|}
\hline \multirow{2}{*}{\begin{tabular}{c}
\multirow{2}{*}{$\begin{array}{c}\text { IAS/IFRS } \\
\text { használata }\end{array}$} \\
\cline { 2 - 5 }
\end{tabular}} & \multicolumn{2}{|c|}{ Konszolidált beszámolók } & \multicolumn{2}{c|}{ Egyedi beszámolók } \\
\hline Kötelező & $100 \%$ & nem tőzsdei & tőzsdei & nem tőzsdei \\
\hline Engedélyezett & - & $89 \%$ & $33 \%$ & $7 \%$ \\
\hline Nem engedélyezett & - & - & $30 \%$ & $44 \%$ \\
\hline
\end{tabular}

Forrás: Sipos [2010] 399. oldal alapján saját szerkesztés

Az egyes országokra vonatkozó részletes megjegyzéseket lásd a hivatkozott kutatásban (Use of IFRSs by Jurisdiction). 


\subsection{Nemzetközi számviteli szabályozási szint - Európai Uniós irányelvek}

Az Európai Uniós jogi szabályozás irányelvek, rendeletek, közlemények és ajánlások segítségével történik. A Római Szerződés 189. cikkelye szerint az irányelvekben foglaltak átvétele kötelező a tagállamok számára. Az adaptálás formáját és módszerét a nemzeti hatóságokra bízzák, így minden tagállam megtarthatta saját jogi és szabályozási rendszerét, abba beépítve kell alkalmazni a direktívákban foglaltakat.

A számvitelhez kötődő direktívák már régóta megtalálhatóak voltak az EU szabályozási rendszerében, a legfontosabbak voltak ezek közül:

- 78/660/EGK, amely az éves beszámoló elkészítésének rendjéről szól (ún. négyes direktíva),

- 83/349/EGK, amely a konszolidációs eljárások szabályozására vonatkozik (ún. hetes direktíva).

Az irányelvek azonban nem jelentik a beszámolási rendszerek harmonizációját, hiszen nem szabályoznak teljes körüen, illetve választási lehetőségeket biztosítanak.

Az EU a harmonizációs folyamatok elősegítése érdekében együttmüködésbe kezdett az IASB-vel, amelynek következtében 2005-től minden tőzsdén jegyzett társaságnak az összevont éves beszámolóját az IFRS-ekkel összhangban kell elkészíteni (1606/2002/EK rendelet a nemzetközi számviteli standardok alkalmazásáról). A rendelet szerint a tagországok megengedhetik vagy megkövetelhetik, hogy ezek a vállalkozások az egyedi beszámolójukat is nemzetközi standardok alapján készíthessék el.

Témám szempontjából kiemelten fontos az Európai Bizottság által 2008-ban elfogadott „Gondolkozz először kicsiben - Európai kisvállalkozói intézkedéscsomag”. Ebben elismerik a kis- és középvállalkozások központi szerepét az Európai Unió gazdaságában.

A Bizottság 2011-ben az „Egységes piaci intézkedéscsomag” címü közleményében javaslatot tett a pénzügyi beszámolási követelmények módosítására vonatkozóan, az adminisztratív terhek csökkentése érdekében a számviteli irányelvek 
egyszerüsítésére. Cél a szabályozásból eredő terhek - különös tekintettel a kkv-kra vonatkozóan - csökkentése uniós és nemzeti szinten egyaránt.

Az irányelvek módosítására az idők folyamán többször sor került, meg kell említeni a negyedik irányelv 2012-es módosítását (2012/6/EU irányelv), amely definiálta a mikrovállalkozás (mikrogazdálkodó-egység) kategóriát:

„A tagállamok ... mentesítést adhatnak az ezen irányelv szerinti egyes kötelezettségek alól azon társaságok tekintetében, amelyek a mérlegfordulónapjukon nem lépik túl a következö három feltétel közül kettőnek a határértékét (mikrogazdálkodó-egységek):

a) mérlegföösszeg: 350000 EUR;

b) nettó árbevétel: 700000 EUR;

c) az üzleti évben átlagosan foglalkoztatottak száma: 10 fö."

Az EU által elfogadott határértéket hosszas vita előzte meg, az eredeti tervekben 500 eEUR mérlegfőösszeg és 1000 eEUR-os árbevétel volt, majd sokáig úgy tủnt, hogy 250 eEUR és 500 eEUR lesz a küszöbérték.

2013. júniusban elfogadásra került a 2013/34/EU irányelv (hatályon kívül helyezve a korábbi számviteli irányelveket) a meghatározott típusú vállalkozások éves pénzügyi kimutatásiról, összevont (konszolidált) éves pénzügyi kimutatásairól és a kapcsolódó beszámolókról.

A korlátozott erőforrásokkal rendelkező mikrovállalkozókra gyakran ugyanazon pénzügyi beszámolási szabályok vonatkoznak, mint a nagyobb vállalkozásokra, ezzel indokolatlanul nagy adminisztratív terhet róva rájuk. Ezt figyelembe véve az irányelv lehetőséget teremt számukra egy egyszerűbb számviteli beszámolásra, amely a beszámoló összeállítására és közzétételére vonatkozó könnyítést is egyaránt magába foglal. 
9. táblázat: Beszámolási sajátosságok

\begin{tabular}{|l|c|c|c|c|}
\hline \multicolumn{1}{|c|}{ Kategória } & $\begin{array}{c}\text { Időbeli } \\
\text { elhatárolás }\end{array}$ & Kiegészítő megjegyzések & $\begin{array}{c}\text { Üzleti } \\
\text { jelentés }\end{array}$ & Közzététel \\
\hline Mikro & Nem kell & Nem kell & Nem kell & Nem kell \\
\hline Kis & Kel & $\begin{array}{c}\text { Számviteli politika, } \\
\text { Átértékelések, } \\
\text { Mérlegen kívüli, rendkívüli } \\
\text { és öt évnél hosszabb lejáratú } \\
\text { Tisztségviselök, Létszám }\end{array}$ & Nem kell & Kell \\
\hline Közepes & $\begin{array}{c}\text { Befektetési tükör } \\
\text { Adózási célú értékelés } \\
\text { Valós értéktől eltérés } \\
\text { Tiszteletdíjak, Létszám } \\
\text { Halasztott adó, tőkeváltozás } \\
\text { Kapcsolt vállalkozások }\end{array}$ & Nem kell & Kell \\
\hline $\begin{array}{l}\text { Nagy, } \\
\text { közérdeklődésü }\end{array}$ & Kell & $\begin{array}{c}\text { Árbevétel tevékenységenként, } \\
\text { országonként, } \\
\text { Könyvvizsgálói díj }\end{array}$ & Kell & Kell \\
\hline
\end{tabular}

Forrás: Lukács (2015)

A tagállamoknak 2015. július 20-ig kellett saját jogszabályaikat (törvényeket, rendeleteket) az irányelvnek megfeleltetni, melyet (Írország kivételével) meg is tettek. 


\subsection{Nemzeti számviteli szabályozási szint - magyar számviteli rendszer}

A nemzeti szintü szabályozást hazánk számviteli rendszerén keresztuil mutatom be, mely magába foglalja a történelmi áttekintést, a jelenleg érvényes beszámolási rendszer felépítését és az alkalmazó kör meghatározását.

\subsubsection{A magyar számviteli rendszer fejlődéstörténete}

A magyar számviteli szabályozás közel háromszáz éves múltra tekint vissza. Ennek részletes történetével többen foglalkoztak műveikben (Baricz [1997b], Nagy [2008], Kardos [2012]).

Az alábbiakban néhány jelentősebb állomás felvillantásával röviden bemutatom a számvitel magyarországi fejlődését.

Az 1723-as kereskedelmi törvény LIII. cikke előírta, hogy a kereskedők a könyveiket szabályszerüen tartoznak vezetni és abban hitelezéseiket pontosan nyilvántartani. Ez a számviteli feljegyzésekre, nyilvántartásokra, kereskedelmi könyvek vezetésére vonatkozó feljegyzés tekinthető a magyar számviteli szabályozás kezdetének.

Az 1875. évi kereskedelmi törvényben már a könyvvezetés módjára, a leltár- és mérlegkészítési kötelezettségre valamint a vagyontárgyak értékelésének módjára vonatkozóan is találunk előírásokat.

Az 1884-es ipari és az adótörvény a vagyontárgyak értékelési módját mélyítette és rendezte a vagyonmérleg és az adómérleg kapcsolatát.

1930-ban bevezetésre került a hites könyvvizsgálói képesítés.

1947-től elrendelték a Kötelező Általános Ipari Számlakeret (KÁLISZ) használatát.

Az 1950-es évektől a tervgazdaság igényeit kiszolgáló, szovjet mintára épülő, a kormányzati szervek felé történő adatszolgáltatás válik a számvitel fő feladatává.

1954-ben pénzügyminiszteri rendelet formájában megjelennek a mérlegbeszámoló tartalmára vonatkozó szabályok. Ekkor határozzák meg, hogy a 
mérlegbeszámolónak leltárból, mérlegből, eredménykimutatásból, azokat kiegészítő mellékletből, valamint szöveges beszámolóból kell állni.

Az 1968-as gazdasági reformot követően elötérbe került a különféle közgazdasági szabályozók működésének mérése. Ekkor került sor a költség, illetve az önköltségszámítással foglalkozó részek mélyítésére.

1988-ban bevezetésre került a társasági- és vállalkozási nyereségadó.

A gazdaság liberalizálása, a tulajdonviszonyok átalakulása, a megjelenő külföldi tőke, illetve multinacionális vállaltok igényei felerősítették a folyamatot, amelynek következtében megszületett a 1991. évi XVIII. törvény a számvitelről, amely az európai uniós jog talaján álló, a kontinentális jog hagyományait követő szabályozás.

Négy alkalommal történt jelentősebb ${ }^{8}$ módosítás: 1994-ben, 2000-ben (ekkor újrakodifikálták a jogszabályt és elfogadták a jelenleg is hatályban lévő 2000. évi C. törvényt a számvitelről), 2003-ban (valós értéken történő értékelés bevezetése a jogszabályban) és 2015-ben (az EU irányelvek változásából eredő jogharmonizáció). A törvényi szabályozás filozófiája azonban nem változott, cél a piaci szereplök részére megbízható és valós összkép bemutatása a beszámolóban.

\subsubsection{Számviteli beszámolási rendszer Magyarországon}

A gazdálkodó egységek az érdekeltek információigényét - főként - a számviteli beszámoló elkészítésével és közzétételével elégítik ki. A magyar számviteli szabályozás szinte differenciálás nélkül vonatkozik valamennyi Magyarországon bejegyzett gazdálkodóra ${ }^{9}$. A bemutatandó információk köre és mélysége azonban nem azonos minden gazdálkodó egységnél, függ a vállalat méretétől, illetve tevékenységi körétől. A disszertáció a méretből adódó különbségek vizsgálatával kiemelten foglalkozik, rávilágítva a KKV-kra vonatkozó egyszerüsítési lehetőségekre.

A számviteli törvény (már a 1991. évi XVIII. törvény is és a jelenleg hatályos 2000. évi C. törvény is) a beszámoltatás tekintetében differenciál a vállalat

\footnotetext{
${ }^{8}$ kisebb módosítások szinte minden évben történnek, azonban ezek önmagukban nem jelentősek

${ }^{9}$ kivételt képeznek az egyéni vállalkozások, akik a személyi jövedelemadó törvény hatálya alá esnek
} 
karakterisztikájának figyelembe vételével. A magyar számviteli beszámolási rendszert alapvetően három mutató: a mérlegföösszeg, az értékesítés nettó árbevétele és a foglalkoztatottak létszáma befolyásolja, hiszen főként ezek alapján dől el, hogy egy gazdálkodónak milyen beszámolót kell készítenie. A határértékeken kívül befolyásoló tényező lehet a vállalkozás társasági formája (például Nyrt-re vonatkozó korlátozások), a tevékenysége (például hitelintézetekre vonatkozó szabályok) illetve, hogy kötelezett-e könyvvizsgálatra.

Alapesetként minden gazdálkodónak éves beszámolót kell készítenie, azonban bizonyos kritériumoknak való megfelelés esetén lehetőség nyílik egyszerübb (szűkebb adattartalmú) beszámoló választására.

Az alábbi beszámoló fajták tartalmaznak valamilyen szintủ egyszerüsítési lehetőséget

- egyszerüsített éves beszámoló;

- egyszerüsített beszámoló;

- sajátos egyszerüsített éves beszámoló (2009-2012);

- mikrogazdálkodói egyszerüsített éves beszámoló (2013-tól).

2016-tól lehetőség nyílt az egyedi beszámolót a nemzetközi pénzügyi beszámolási standardoknak alapján készíteni (2017-től a tőzsdei cégek, 2018-tól a hitelintézetek számára kötelező jelleggel). Ez azonban a vizsgálat fókuszában álló KKV-k esetében nem releváns terület, így ennek részleteivel nem foglalkozom.

A továbbiakban bemutatom a KKV-kre jellemző beszámolók alkalmazhatósági körét, illetve a bennük rejlő egyszerüsítési lehetőségeket az éves beszámolóhoz képest (részletesen a 4.2. fejezet tartalmazza). Megvizsgálom, hogy mennyire terjedtek el, mennyire éltek a vállalkozások a választás lehetőségével.

Az alkalmazhatósági kört alapvetően a kapcsolódó jogszabályokban megtalálható határértékek döntik el, ennek alakulását (1992-2017) foglalja össze a 13. ábra. 
13. ábra: A magyar számviteli beszámolási rendszert befolyásoló határértékek alakulása

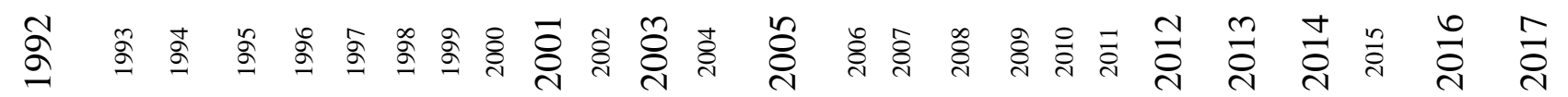

\section{Egyszerúsített éves beszámoló}

Mérlegföösszeg ( $\mathrm{mFt}$ )

Értékesítés nettó árbevétele $(\mathrm{mFt})$

Létszám (fö)

\section{Egyszerüsített beszámoló}

(Ért. nettó árbev., mFt)

Sajátos egyszerüsített éves beszámoló (Nem határérték függő)

\section{Mikrogazdálkodói EÉB}

Mérlegföösszeg (mFt)

Értékesítés nettó árbevétele $(\mathrm{mFt})$

Létszám (fö)

Nincs beszámoló (EVA miatt, Bev. $\mathrm{mFt}$ )

Nincs beszámoló (KATA miatt, Bev. $\mathrm{mFt}$ )
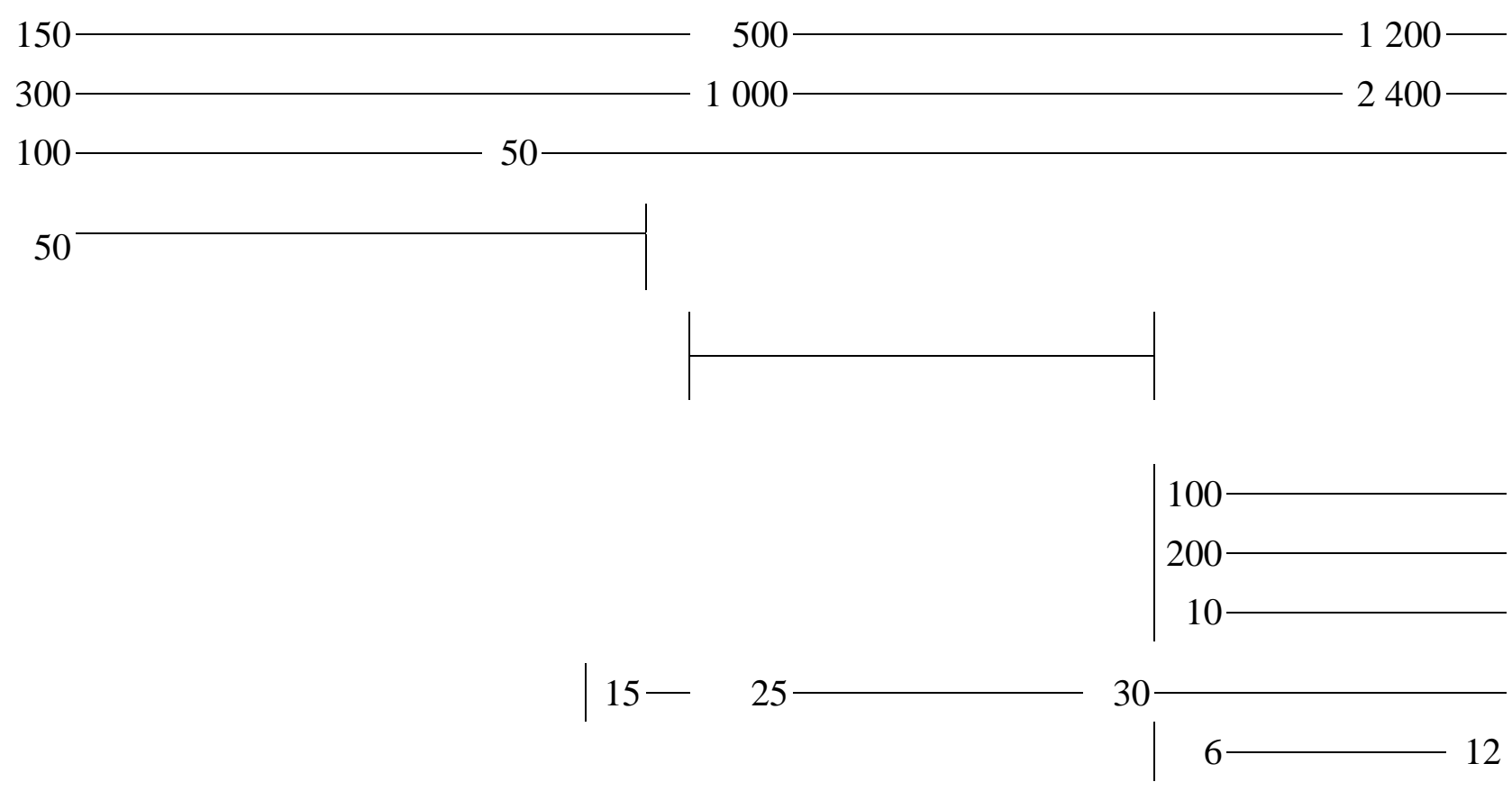
$1000-300-0$

Könyvvizsgálat (Ért. nettó árbev., $\mathrm{mFt}$ ) 
Az OTPEN által rendelkezésre bocsátott adatok alapján megvizsgáltam a közzétett beszámolók megoszlását.

10. táblázat: A közzétett beszámolók száma

\begin{tabular}{|l|r|r|r|r|}
\hline Beszámoló típusa & \multicolumn{1}{c|}{$\mathbf{2 0 0 5}$} & \multicolumn{1}{c|}{$\mathbf{2 0 0 9}$} & \multicolumn{1}{c|}{$\mathbf{2 0 1 3}$} & \multicolumn{1}{c|}{$\mathbf{2 0 1 5}$} \\
\hline Éves beszámoló & 32211 & 33464 & 24220 & 23093 \\
\hline Egyszerüsített éves beszámoló & 307370 & 341212 & 366619 & 332487 \\
\hline $\begin{array}{l}\text { Sajátos egyszerüsített } \\
\text { éves beszámoló }\end{array}$ & & 19654 & & \\
\hline $\begin{array}{l}\text { Mikrogazdálkodói egyszerűsített } \\
\text { éves beszámoló }\end{array}$ & & & 60181 & 82911 \\
\hline \hline Összesen & $\mathbf{3 3 9 5 8 1}$ & $\mathbf{3 9 4} \mathbf{3 3 0}$ & $\mathbf{4 5 1 0 1 9}$ & $\mathbf{4 3 8} \mathbf{4 9 1}$ \\
\hline
\end{tabular}

Forrás: OPTEN adatai alapján saját szerkesztés

11. táblázat: A közzétett beszámolók megoszlása

\begin{tabular}{|l|r|r|r|r|}
\hline Beszámoló típusa & \multicolumn{1}{c|}{$\mathbf{2 0 0 5}$} & \multicolumn{1}{c|}{$\mathbf{2 0 0 9}$} & \multicolumn{1}{c|}{$\mathbf{2 0 1 3}$} & \multicolumn{1}{c|}{$\mathbf{2 0 1 5}$} \\
\hline Éves beszámoló & $9,5 \%$ & $8,5 \%$ & $5,4 \%$ & $5,3 \%$ \\
\hline Egyszerüsített éves beszámoló & $90,5 \%$ & $86,5 \%$ & $81,3 \%$ & $75,8 \%$ \\
\hline $\begin{array}{l}\text { Sajátos egyszerüsített } \\
\text { éves beszámoló }\end{array}$ & - & $5,0 \%$ & - & - \\
\hline $\begin{array}{l}\text { Mikrogazdálkodói egyszerüsített } \\
\text { éves beszámoló }\end{array}$ & - & - & $13,3 \%$ & $18,9 \%$ \\
\hline \hline Összesen & $\mathbf{1 0 0 , 0} \%$ & $\mathbf{1 0 0 , 0} \%$ & $\mathbf{1 0 0 , 0} \%$ & $\mathbf{1 0 0 , 0} \%$ \\
\hline
\end{tabular}

Forrás: OPTEN adatai alapján saját szerkesztés

Megállapítható tehát, hogy a vállalkozások több mint $90 \%$-a él valamilyen egyszerűsítési lehetőséggel. Mivel a választás alapvetően a vállalkozás nagyságától függ érdemes megvizsgálni a magyarországi vállalkozásszerkezetet méret szerinti differenciálódását. 


\section{A vállalkozások méret szerinti differenciálódása}

$\mathrm{Az}$ értekezésben a vállalkozások méret szerinti differenciálását több féle megközelítés szerint vizsgálom. Először az Európai Uniós kritériumrendszernek megfelelő kategóriákat tekintem át, majd a számvitel által alkalmazott határértékek kerülnek a fókuszba.

Az Európai Unió 2003/361/EK irányelve határozza meg a mikro-, kis-, és középvállalkozások kategóriájára vonatkozó kritériumokat, amelyek bekerültek a tagállamok - így hazánk ${ }^{10}$ - jogrendjébe is.

Az uniós KKV kritériumok alapján történő besorolásnál két mutatónak kell a határérték alatt lennie, de ebből az egyik mindenképpen a létszám. Emellett feltétel, hogy az állam vagy az önkormányzat közvetlen vagy közvetett tulajdoni részesedése (tőke vagy szavazati jog alapján) nem haladhatja meg (külön-külön, vagy együttesen) a 25\%-ot. A kategóriák értékhatárait a következő táblázat tartalmazza.

12. táblázat: Vállalkozások méret szerinti kategóriáinak határértékei

\begin{tabular}{|l|r|r|r|r|r|}
\hline \multicolumn{1}{|c|}{ Kategóriák } & Létszám & \multicolumn{2}{c|}{ Mérleg föösszeg* } & \multicolumn{2}{c|}{ Árbevétel* } \\
\hline Mikrovállalkozás & 10 fö & 2000 e€ & $600 \mathrm{mFt}$ & $2000 \mathrm{e} €$ & $600 \mathrm{mFt}$ \\
\hline Kisvállalkozás & $50 \mathrm{fö}$ & $10000 \mathrm{e} €$ & $3000 \mathrm{mFt}$ & $10000 \mathrm{e} €$ & $3000 \mathrm{mFt}$ \\
\hline Közepes vállalkozás & 250 fö & 43000 e€ & $12900 \mathrm{mFt}$ & $50000 \mathrm{e} €$ & $15000 \mathrm{mFt}$ \\
\hline Nagy vállalkozás & \multicolumn{2}{|c|}{ az elözö kategóriákba be nem sorolt vállalkozások } \\
\hline
\end{tabular}

* 300 Ft/€ árfolyammal számolva

Forrás: 2004. évi XXXIV. törvény 3. § alapján saját szerkesztés

A magyarországi KKV-k főbb jellemzőinek (10. táblázat) vizsgálata során megállapítható jelentős szerepük, hiszen a foglalkoztatás több mint $70 \%$-át, a hozzáadottérték-termelés több mint felét adják. Nemzetközi összehasonlításban

\footnotetext{
${ }^{10}$ 2004. évi XXXIV. törvény a kis- és középvállalkozásokról, fejlődésük támogatásáról
} 
megfigyelhető (főként a mikrovállalkozások esetén), hogy a foglalkoztatás meghaladja, a hozzáadottérték-termelés esetében azonban alatta van az EU átlagnak.

13. táblázat: KKV-k Magyarországon - alapadatok

\begin{tabular}{|c|c|c|c|c|c|c|c|c|c|}
\hline & \multicolumn{3}{|c|}{ Vállalkozások száma } & \multicolumn{3}{|c|}{$\begin{array}{c}\text { Foglalkoztatottak } \\
\text { száma }\end{array}$} & \multicolumn{3}{|c|}{ Hozzáadott érték } \\
\hline & \multicolumn{2}{|c|}{ Magyarország } & \multirow{2}{*}{\begin{tabular}{|c|} 
EU-28 \\
\end{tabular}} & \multicolumn{2}{|c|}{ Magyarország } & \multirow{2}{*}{\begin{tabular}{|c|} 
EU-28 \\
$\%$ \\
\end{tabular}} & \multicolumn{2}{|c|}{ Magyarország } & \multirow{2}{*}{$\begin{array}{c}\text { EU-28 } \\
\%\end{array}$} \\
\hline & db & $\%$ & & fö & $\%$ & & M€ & $\%$ & \\
\hline Mikro & 489767 & 94,1 & 92,8 & 861275 & 34,4 & 29,5 & 9,6 & 18,1 & 21,2 \\
\hline Kis & 25750 & 4,9 & 6,0 & 479997 & 19,2 & 20,2 & 8,6 & 16,3 & 18,0 \\
\hline Közepes & 4131 & 0,8 & 1,0 & 404644 & 16,2 & 17,0 & 9,5 & 18,0 & 18,2 \\
\hline Kkv-k össz. & 19648 & 99,8 & 99,8 & 1745916 & 69,7 & 66,8 & 27,7 & 52,5 & 57,4 \\
\hline Nagy & 877 & 0,2 & 0,2 & 757678 & 30,3 & 33,2 & 25,1 & 47,5 & 42,6 \\
\hline Összesen & 520525 & 100,0 & 100,0 & 2503594 & 100,0 & 100,0 & 52,9 & 100,0 & 100,0 \\
\hline
\end{tabular}

Forrás: Európai Bizottság - SBA jelentés [2016]

A KKV-k gazdaságban betöltött kiemelkedő szerepe miatt különösen fontos, hogy a rájuk vonatkozó szabályokat - ide értve a számviteli beszámoltatásukra vonatkozó előírásokat is - a sajátosságaikat jobban figyelembe vevő módon alakítsák ki.

Sokszor előkerült már, hogy ezek a határszámok túl magasak és nem illeszkednek az országok jellemzőihez. Néhány terület - így a számvitel is - ennél kisebb határértéket alkalmaz saját rendszerében a kategóriák kialakításakor.

Ez nem csak Magyarországon ${ }^{11}$ van így, hanem számos más uniós ország esetében is, például Litvánia esetén az egyszerüsített beszámoló határértékei: mérlegföösszeg 1700000 €, nettó árbevétel 2900000 €, átlagos állományi létszám 15 fö; Szlovákia esetén mérlegfőösszeg $1000000 €$, nettó árbevétel $2000000 €$, létszám: 30 fő. ${ }^{12}$ Ezek - a tagállamok által meghatározott - határértékek jobban igazodnak az adott ország vállalkozásszerkezetéhez.

\footnotetext{
${ }^{11}$ A Magyarországon alkalmazott számviteli határértékek összefoglalása a 13. ábrán található.

${ }^{12}$ Európai Bizottság [2015] adatai alapján
} 
Ha összevetjük a két rendszer határérték meghatározását, akkor az értékek különbözőségén túl is találunk eltérést.

14. táblázat: KKV és számviteli határértékek (2015)

\begin{tabular}{|c|c|c|c|c|c|}
\hline & \multicolumn{3}{|c|}{$\begin{array}{c}\text { KKV törvény } \\
\text { 3. } \S(1)-(3) \text { bekezdés }\end{array}$} & \multicolumn{2}{|c|}{$\begin{array}{l}\text { Számviteli törvény } \\
9 . \S(2),(6) \text { bekezdés }\end{array}$} \\
\hline & $\begin{array}{l}\text { Mikro- } \\
\text { vállalkozás }\end{array}$ & $\begin{array}{c}\text { Kis- } \\
\text { vállalkozás }\end{array}$ & $\begin{array}{c}\text { Közép- } \\
\text { vállalkozás }\end{array}$ & $\begin{array}{c}\text { Mikrogazdálkodói } \\
\text { egyszerüsített } \\
\text { éves } \\
\text { beszámoló }\end{array}$ & $\begin{array}{c}\text { Egyszerüsített } \\
\text { éves } \\
\text { beszámoló }\end{array}$ \\
\hline Mérlegföösszeg & $\leq 2 \mathrm{m€}$ & $\leq 10 \mathrm{~m} €$ & $\leq 43 \mathrm{m€}$ & $\leq 100 \mathrm{mFt}$ & $\leq 500 \mathrm{mFt}$ \\
\hline Árbevétel & $\leq 2 \mathrm{m€}$ & $\leq 10 \mathrm{~m} €$ & $\leq 50 \mathrm{m€}$ & $\leq 200 \mathrm{mFt}$ & $\leq 1000 \mathrm{mFt}$ \\
\hline \multirow[t]{2}{*}{ Létszám } & $<10$ fö & $<50$ fö & $<250$ fö & $\leq 10$ fö & $\leq 50$ fö \\
\hline & \multicolumn{3}{|c|}{$\begin{array}{c}\text { „létszám kevesebb és } \\
\text { árbevétel vagy mérlegföösszeg } \\
\text { legfeljebb” }\end{array}$} & \multicolumn{2}{|c|}{$\begin{array}{c}\text { „három mutatóérték közül } \\
\text { bármelyik kettő } \\
\text { nem haladja meg” }\end{array}$} \\
\hline
\end{tabular}

Forrás: Jogszabályokban szereplő határértékek alapján saját szerkesztés

Bár mindkét rendszer ugyanazt a három méretkategorizáló ismérvet használja, a KKV-s besorolás a létszámnak prioritást ad a másik kettő mellett (, létszám kevesebb és árbevétel vagy mérlegföösszeg legfeljebb”), míg a számviteli beszámolóknál nincs kiemelve egyik sem („,három mutatóérték közül bármelyik kettő nem haladja meg”).

A KKV-s besorolásnál a létszám esetében a határértékkel való egyezés már a nagyobb kategóriába való tartozást jelenti, míg a mérlegföösszeg és az árbevétel esetében, valamint a számviteli beszámolók kategóriáinál a határértékkel való egyezés még belefér a kisebb kategóriába. Ezt szemlélteti az alábbi összehasonlító ábra, ahol a szürkével jelzett területek mutatják, hogy ki tartozik a nagyobb kategóriába. 
14. ábra: A KKV és számviteli beszámoló besorolási határértékeinek filozófiai különbsége
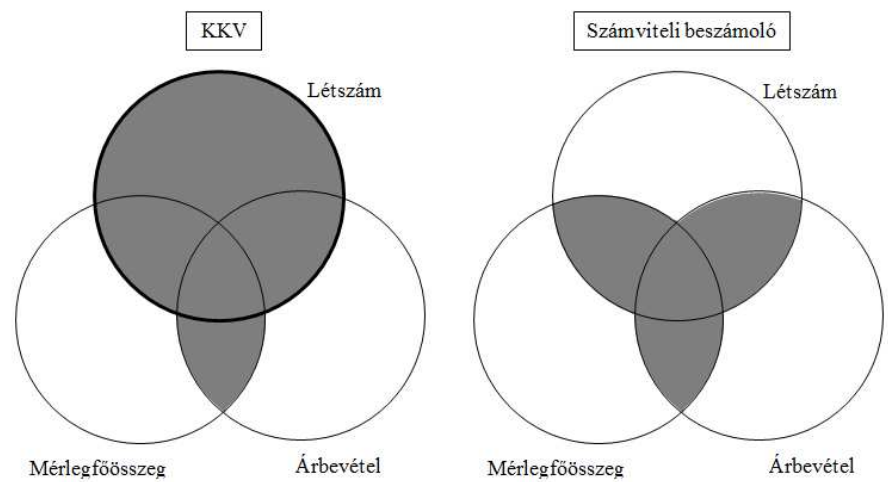

Forrás: Jogszabályokban szereplö határértékek alapján saját szerkesztés

A kétféle rendszerben különbséget jelent, hogy a KKV-s kategóriáknál ugyanakkora értéket alkalmaznak a mérlegföösszegnél és az árbevételnél is (egyedül a középvállalkozásoknál van kisebb eltérés), míg a számviteli beszámolóknál a mérlegföösszeg határértéke fele az árbevételi küszöbnek. A létszámot összevetve a két értékadattal is jelentős különbség adódik, mivel a KKV-k esetében $60 \mathrm{mFt} / \mathrm{fő} \mathrm{az}$ alkalmazott arány, viszont a számviteli beszámolóknál ez csak $10 \mathrm{mFt} /$ fő a mérlegföösszegnél és 20 mFt/fő az árbevétel esetében.

A Budapesti Corvinus Egyetem és a Nemzeti Adó- és Vámhivatal (NAV) együttmüködése keretében rendelkezésre bocsátott 2015. évi társasági adóbevallások összesen 420523 gazdálkodó szervezetre vonatkozó - adatait tartalmazó adatbázis alapján elvégeztem a kétféle besorolás szerinti kategorizálást. Kizárólag a méretre vonatkozó adatok alapján vizsgáltam, egyéb tényezők (pl. társasági forma, tevékenység) nem kerültek figyelembe vételre. A számviteli kategória esetén a 2015-ben hatályos határértékek kerültek figyelembe vételre. 
15. táblázat: Magyarországi vállalkozások KKV és számviteli méretkategorizálása (2015)

a) vállalkozások száma szerint

\begin{tabular}{|l|r|r|r||r|}
\hline & \multicolumn{1}{|c|}{ MG } & \multicolumn{1}{c|}{ EÉ } & \multicolumn{1}{c|}{ ÉB } & Összesen \\
\hline Mikro & 380038 & 7411 & 81 & 387530 \\
\hline Kis & 9240 & 15223 & 2693 & 27156 \\
\hline Közepes & 178 & 1001 & 3665 & 4844 \\
\hline Nagy & 5 & 36 & 952 & 993 \\
\hline \hline Összesen & 389461 & 23671 & 7391 & 420523 \\
\hline
\end{tabular}

b) KKV kategóriák megoszlása szerint (sormegoszlás)

\begin{tabular}{|l|r|r|r|r|}
\hline & \multicolumn{1}{|c|}{ MG } & \multicolumn{1}{c|}{ EÉ } & \multicolumn{1}{c|}{ ÉB } & Összesen \\
\hline Mikro & $98,1 \%$ & $1,9 \%$ & $0,0 \%$ & $100,0 \%$ \\
\hline Kis & $34,0 \%$ & $56,1 \%$ & $9,9 \%$ & $100,0 \%$ \\
\hline Közepes & $3,7 \%$ & $20,7 \%$ & $75,7 \%$ & $100,0 \%$ \\
\hline Nagy & $0,5 \%$ & $3,6 \%$ & $95,9 \%$ & $100,0 \%$ \\
\hline \hline Összesen & $92,6 \%$ & $5,6 \%$ & $1,8 \%$ & $100,0 \%$ \\
\hline
\end{tabular}

c) Számviteli kategóriák megoszlása szerint (oszlopmegoszlás)

\begin{tabular}{|l|r|r|r||r|}
\hline & \multicolumn{1}{|c|}{ MG } & \multicolumn{1}{c|}{ EÉ } & \multicolumn{1}{c|}{ ÉB } & Összesen \\
\hline Mikro & $97,6 \%$ & $31,3 \%$ & $1,1 \%$ & $92,2 \%$ \\
\hline Kis & $2,4 \%$ & $64,3 \%$ & $36,4 \%$ & $6,5 \%$ \\
\hline Közepes & $0,0 \%$ & $4,2 \%$ & $49,6 \%$ & $1,2 \%$ \\
\hline Nagy & $0,0 \%$ & $0,2 \%$ & $12,9 \%$ & $0,2 \%$ \\
\hline \hline Összesen & $100,0 \%$ & $100,0 \%$ & $100,0 \%$ & $100,0 \%$ \\
\hline
\end{tabular}

d) vállalkozások számának megoszlása szerint

\begin{tabular}{|l|r|r|r||r|}
\hline & \multicolumn{1}{|c|}{ MG } & \multicolumn{1}{c|}{ EÉ } & \multicolumn{1}{c|}{ ÉB } & Összesen \\
\hline Mikro & $90,4 \%$ & $1,8 \%$ & $0,0 \%$ & $92,2 \%$ \\
\hline Kis & $2,2 \%$ & $3,6 \%$ & $0,6 \%$ & $6,5 \%$ \\
\hline Közepes & $0,0 \%$ & $0,2 \%$ & $0,9 \%$ & $1,2 \%$ \\
\hline Nagy & $0,0 \%$ & $0,0 \%$ & $0,2 \%$ & $0,2 \%$ \\
\hline \hline Összesen & $92,6 \%$ & $5,6 \%$ & $1,8 \%$ & $100,0 \%$ \\
\hline
\end{tabular}

Magyarázat: MG: Mikrogazdálkodói beszámoló; EÉ: Egyszerüsített éves beszámoló; ÉB: Éves beszámoló Forrás: NAV 2015. TAO adatbázis alapján saját számítás 
A mikrovállalkozások aránya $92,2 \%$ a vizsgált sokaságon belül, azonban ha a számviteli besoroláshoz hasonlóan a KKV-s besorolásnál sem emeljük ki a létszámot prioritásként, hanem egyenrangúként kezeljük a három méretkategorizáló ismérvet, akkor még jelentősebb lesz a mikrovállalkozások aránya (97,0\%). A módosítás a vállalkozások többségét $(94,5 \%)$ nem érinti, viszont 5,5\%-a a vállalkozásoknak kisebb kategóriába kerülne. Ezeket szemlélteti a következő táblázat.

16. táblázat: Magyarországi vállalkozások KKV méretkategorizálása létszámprioritással és anélkül (2015)

\begin{tabular}{|c|c|c|c|c|c|c|c|}
\hline & \multicolumn{6}{|c|}{ Kategória létszám prioritás nélkül } \\
\hline & & Mikro & Kis & Közepes & Nagy & Összesen & Arány \\
\hline \multirow{6}{*}{ 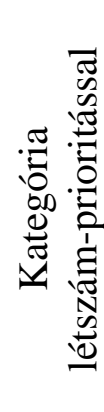 } & Mikro & 387530 & & & & 387530 & $92,2 \%$ \\
\hline & Kis & 19434 & 7722 & & & 27156 & $6,5 \%$ \\
\hline & Közepes & 890 & 2159 & 1795 & & 4844 & $1,2 \%$ \\
\hline & Nagy & 29 & 109 & 331 & 524 & 993 & $0,2 \%$ \\
\hline & Összesen & 407883 & 9990 & 2126 & 524 & 420523 & $100,0 \%$ \\
\hline & Arány & $97,0 \%$ & $2,4 \%$ & $0,5 \%$ & $0,1 \%$ & $100,0 \%$ & \\
\hline
\end{tabular}

Forrás: NAV 2015. TAO adatbázis alapján saját számítás

Elvégeztem a vizsgálatot a 2016-os határérték-változás figyelembe vételével is. Ez kizárólag az éves beszámolóra vonatkozóan jelentett módosulást, 3335 vállalkozás $(0,8 \%)$ átkerült az egyszerüsített éves beszámoló kategóriába. Tisztán a határértékek figyelembe vételével a vállalkozások mindössze 1 \%-a marad az éves beszámoló összeállítására kötelezett körben.

A méret szerinti elkülönítéssel és ennek a beszámoló tartalmára vonatkozó következményével többek között Baricz [1997b], Riahi-Belkaoui [2000], Kovács Mohl [2011] foglalkozott. 


\section{Adminisztrativ terhek nagyságára vonatkozó felmérések}

Az Európai Tanács már 2007-ben kiemelte, hogy az adminisztratív terhek csökkentése Európa gazdaságának fellendítése szempontjából rendkívül fontos tényező. Akcióprogramot dolgozott ki az adminisztrációs terhek felmérésére és azok csökkentésére (a terv eredetileg 2012-ig $25 \%$-os csökkentés). A program a számvitelt az egyik kulcsfontosságú területnek minősítette és megkezdte a számviteli beszámolást és a könyvvizsgálatot érintő egyszerüsítési lehetőségek vizsgálatát.

Ez az alábbi területeken valósulhat meg:

- a KKV-kra vonatkozó mentesítési lehetőségek körének bővítése (alapvetően az értékelésre, a bemutatásra, a közzétételre, a könyvvizsgálati kötelezettségre vonatkozóan);

- a választási lehetőségek módosítása vagy eltörlése (a számviteli irányelvek által biztosított választási lehetőségek által teremtett rugalmasság nehezíti a beszámolók összehasonlíthatóságát);

- a KKV-kra vonatkozó számviteli elöírások egyszerüsítése (könnyebben értelmezhető és alkalmazható előírások létrehozása);

- a bemutatással kapcsolatos elöírások csökkentése (a nyilvánosságra hozott információk többnyire csak korlátozottan minősülnek releváns adatnak, bemutatási kötelezettség átgondolása).

Az adminisztratív terhek mértékének meghatározására több felmérés is készült az elmúlt időszakban.

Ebböl az egyik legismertebb az Európai Unió költségcsökkentési programját is megalapozó 2005-ben publikált Kox tanulmány. Eszerint Magyarországon a GDP 6,8 százalékát tették ki az adminisztratív terhek (a 2000-es évek elején), amely jelentősen meghaladta az uniós átlagot (3,4\%). Hazánk a vizsgálatba bevont 19 ország közül az utolsó helyre került. (Hétfa [2010])

A Deloitte Zrt. által 2010. májusban közzétett tanulmány szerint Magyarországon a vállalkozások adminisztratív költségei a GDP 10,5 százalékát teszik 
ki (számítások szerint ez 2800 milliárd Ft), ebből a feleslegesnek tartott adminisztrációs teher 3,1 százalék (800 milliárd Ft). (Hétfa [2010])

Az adminisztratív költség és teher fogalma közötti különbség tisztázása fontos a téma áttekintése érdekében (Reszkető - Váradi [2010]).

Adminisztratív költségnek tekintjük az egyes jogszabályoknak való megfelelés költségeit (lehet külső-belső, egyszeri-ismétlődő).

Adminisztratív teher: az adminisztratív költségek normál üzletmeneten túli része (a normál müködés során a vállalkozás elhagyná őket, ha nem írná elő neki valamilyen jogszabály adminisztratív/informatikai kötelezettségként).

A Deloitte Zrt. által készített tanulmány beazonosítja a 20 legnagyobb terhet jelentő kötelezettséget. A vizsgálat szerint a legnagyobb vállalkozói terhet a könyvvezetési kötelezettség (1.) jelenti, az egyéb kiemelt tételek alapvetően az adózáshoz köthetőek. További két számvitelhez köthető kötelezettséget említenek: a számviteli politika kialakítása, éves áttekintése, törvénymódosítás miatti módosítási kötelezettsége (16.), a kötelező könyvvizsgálat (18). (Hétfa [2010])

A számvitel számlájára írt adminisztratív teher nagysága nehezen meghatározható, hiszen a számvitel nem önmagáért van, hanem hogy a megfelelő információkat szolgáltassa a különféle területeknek. Például a társasági adó meghatározása esetén a számvitel által előállított adózás előtti eredmény a kiinduló alapja az adó meghatározásának, ebből vezeti le az adótörvény a módosító tételek figyelembe vételével az adóalapot.

A számvitelhez köthető adminisztratív terhek sok esetben elenyészőek az adózási adminisztrációhoz képest, még ha bizonyos értelemben átfedés is van köztük. (BCE Pénzügyi Számvitel Tanszék [2007]). Az adó és járulékok nyilvántartási, bevallási, befizetési kötelezettségiböl származó adminisztratív terhek magas volta az adózási rendszer összetettségéből ered (sokféle adónem, átláthatatlan, nehezen értelmezhető szabályozás). Kritikaként szokták még említeni, hogy az adatokat több hatóság számára is szolgáltatni kell párhuzamosan (például adóhatóság, önkormányzat, céginformációs szolgálat, statisztikai hivatal). 
Balás Gábor és Vékony Benjámin tanulmányában (Balás - Vékony [2009]) rámutat, hogy a piaci müködésre vonatkozó összes előírás betartása sok esetben az üzletmenetet lehetetlenné tevő költségekkel járna. Vizsgálatuk szerint az adminisztratív költségek a kisvállalkozásokat sújtják elsősorban, versenyhátrányba hozva őket a nagyobb cégekkel szemben. Mélyinterjús felmérésük szerint az adminisztrációra fordított összeg a nagyobb vállalkozásoknál is eléri a nettó árbevétel 1\%-át, a kisebb vállalkozások esetében (főleg azok alsó kategóriájában) 10 \% körüli összeget becsültek. Ennek nagyobb része nem a könyvelőknek fizetett összegből, hanem az adórendszernek való megfelelés költségeiből adódót.

15. ábra: Adminisztratív célok ellátására külsősöknek fizetett összeg az árbevétel százalékában

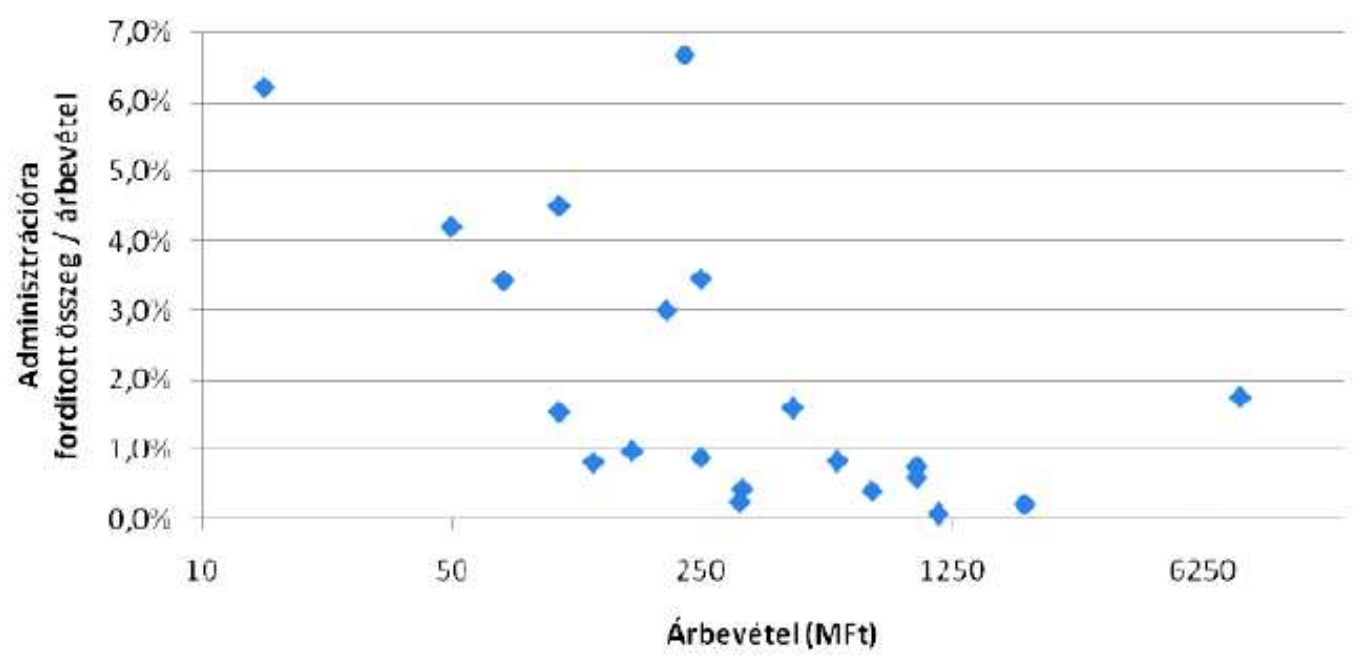

Forrás: Balás - Vékony [2009] 11. oldal

Majoros [2010] disszertációjában kiemeli, hogy az adminisztráció okozta többletterhek különösen a kisebb gazdálkodók versenyképességét csökkenthetik. A KKV-k adminisztrációs terheinek csökkentésére több kísérlet, példa is volt már, de áttörő mértékü változást egyik sem hozott.

A kutatások tehát rámutattak, hogy a KKV-k esetében különösen megterhelőek lehetnek az adminisztratív terhek. Fontos, hogy rájuk szabott, specialitásaikat figyelembe vevő rendszer vonatkozzon rájuk a gazdasági élet különböző területein, így a számvitel esetében is. 


\section{KKV-k számviteli beszámolási rendszere}

KKV-ra vonatkozó, sajátosságaikat figyelembe vévő számviteli szabályozás nemzetközi és nemzeti szinten egyaránt megtalálható.

\subsection{KKV számvitel - Nemzetközi szint - IFRS for SMEs}

A nemzetközi számviteli standardok 40 éves történelme során egyértelmüen kiderült, hogy a rendszer alkalmazhatóságának egyik legnagyobb korlátja, hogy az IFRS-ek kifejezetten nagyvállalkozások számviteli szabályozására szolgál. Az IASB már 2003-ban megfogalmazta azon célkitűzését, hogy a hatályos IFRS-ekre támaszkodva külön számviteli szabályrendszert dolgoz ki a kis- és középvállalkozásokra. 5 év standardalkotási folyamatot követően 2009 júliusában bocsátotta $\mathrm{ki}^{13}$ az IFRS SME standardot.

Az elmúlt években egyre erősödő nemzetközi igény mutatkozott a fejlett és fejlődő országok részéről a kis- és középvállalkozásokra vonatkozó precíz és egységes számviteli standardok iránt (ami a teljes IFRS szabályoknál lényegesen egyszerübb elöírásokkal rendelkezik).

Ezt az igényt próbálta kielégíteni az IASB az IFRS SME megalkotásával, amelynek előnyei:

- magasabb szintü összehasonlítási lehetőséget ad a kimutatások, beszámolók felhasználóinak;

- erősíti a kis- és középvállalkozások elszámolásai, beszámolói iránti bizalmat;

- csökkenti a nemzeti számviteli elöírásoknak való megfelelés jelentős költségeit.

Az IASB nem a vállalati mérethez köti a kis- és középvállalkozás meghatározását. A standard szerint azok a gazdálkodóegységek minősülnek kis- és középvállalkozásnak, amelyeknek nincs nyilvános elszámolási kötelezettségük (public

\footnotetext{
${ }^{13}$ A kibocsátást 2004-ben a Discussion Paper (vitairat), 2007-ben pedig az Exposure Draft (nyilvános tervezet) előzte meg.
} 
accountibility), és általános célú pénzügyi kimutatást tesznek közzé külső felhasználóik számára.

Nyilvános elszámolási kötelezettsége van egy gazdálkodó egységnek, ha:

- adósság- és/vagy tőkeinstrumentumait nyílt piaci kereskedelemben forgalmazzák;

- a gazdálkodó eszközeit elsődleges tevékenységéhez kapcsolódóan vagyonkezelőre bízza, mint például bank, biztosítótársaság, nyugdíjalapok, értékpapírforgalmazók, befektetési bankok.

Külső felhasználó lehet például a tulajdonos, amennyiben nem vesz részt a gazdálkodóegység irányításában, vezetésében, továbbá a jelenlegi és potenciális hitelezők, a szállítók, a vevők és a hitelminősítő intézetek.

Az IFRS SME alkalmazásáról (kötelező, lehetséges vagy nem engedélyezett) az adott ország szabályozó szervezetinek, törvényalkotóinak kell döntést hozniuk.

Az alkalmazást megelőzően a következő tényezőket kell végiggondolni (Madarasiné [2013]):

- a számviteli és pénzügyi beszámolási kötelezettség nemzeti/helyi szinten;

- kik az elsődleges felhasználói a pénzügyi kimutatásoknak;

- IFRS SME alkalmazása esetén megoldható-e az összehasonlítás más vállalkozásokkal;

- hosszú távú tervek, nemzetköziesedés, tőzsdei bevezetés kérdései;

- az alkalmazás üzleti hatásai például a nettó eredményre, a mutatókra, a társasági adófizetésre, osztalékfizetésre;

- a bevezetés költségei, a jövőbeni oktatási költségek, tanácsadó igénybevételének díja;

- IFRS SME elfogadottsága.

Az IFRS SME a következő alapelveket nevesíti: érthetőség, jelentőség, lényegesség, megbízhatóság, tartalom elsődlegessége a formával szemben, óvatosság, teljesség, összehasonlíthatóság, időszerűség, költség-haszon elv. Ez utóbbi alapelv érvényesülését figyelhetjük meg a teljes IFRS-hez képest megjelenő egyszerüsítésben. A könnyítés egyrészt szakmai szempontból történt, bizonyos (KKV-k szempontjából 
nem releváns) témák kihagyása, egyes számviteli elszámolási alternatívák esetén az egyszerübb kötelezővé tétele (választási lehetőségek megszüntetése), a megjelenítés, mérés, illetve a közzététel követelményinek egyszerüsítése, másrészt a standard nyelvezete és terjedelme (körülbelül $10 \%$-a) is egyszerübb a teljes IFRS-nél.

A részletekbe menő bemutatás helyett a főbb hasonlóságok és különbségek megemlítését tartom szükségesnek (Ernst \& Young [2010] és Jermakowicz-Epstein [2010] alapján).

Mindkét esetben (teljes IFRS és IFRS SME):

- a pénzügyi kimutatás mérlegből, eredménykimutatásból. saját tőke változás kimutatásból, cash flow kimutatásból és megjegyzésekből áll (nincs elhagyható rész);

- a pénzügyi kimutatások elvárt minőségi jellemzői megegyeznek;

- vagyoni elemek megragadásához szükséges definíciók megegyeznek;

- hosszú és rövid táv megbontásának követelménye megjelenik;

- a pénzügyi kimutatás készítése minimum éves szintủ rendszerességgel kell, hogy megtörténjen és a különböző periódusok kimutatásainak egymással konzisztensnek kell lennie.

Főbb különbségek:

- az IFRS SME kevesebb pótlólagos információ közlését teszi kötelezővé (például nem feltétel az EPS bemutatása, közbenső pénzügyi jelentések, szegmens jelentések készítése);

- kimaradó (KKV-k esetén nem releváns) témák (például értékesítésre tartott eszközök, biztosítási szerződések, értékesíthető és lejáratig tartandó pénzügyi instrumentumok);

- elszámolási alternatívák megszüntetése (például az állami támogatásokat minden esetben bevételként kell kimutatni, nem választható átértékelési modell);

- egyszerübb közzétételi követelmények.

Több kutatás is foglalkozik azzal, hogy a kis- és középvállalkozásokra vonatkozó IFRS milyen hatással lenne az egyes országok számviteli rendszerére, vállalkozásaira. 
A kutatások egyik iránya az országok KKV-kra vonatkozó aktuális számviteli szabályozását tekintette át, országtanulmányok formájában. Ezek a vizsgálatok rámutattak, hogy meglehetősen heterogén a szabályozás.

Nobes [2010] rámutat, hogy meglehetősen sokféle, eltérő számviteli szabályrendszer van Európában, ráadásul több országban van egynél több helyi szabály, például Németországban a közzétételre és bemutatásra vonatkozó előírások eltérőek a vállalatméret függvényében. Az KKV IFRS és a nemzeti számviteli rendszerek közötti távolságból adódóan eltérés lehet a kimutatott jövedelem nagyságában, ezért azon országokban ahol a számviteli eredmény alapján történik az adómeghatározás jellemzően nem engedik a nemzetközi szabályok alkalmazását.

Mindenképpen érdemes kiemelni az Európai Unió által finanszírozott 20 országra kiterjedő kis- és középvállalkozások számviteli rendszerét vizsgáló, 2011 nyarán publikált átfogó tanulmányt, amelyet a CNA Interpreta S.r.l készített (Study on accounting requirements for SMEs), amely mélyrehatóan vizsgálta az egyes országokban meglévő számviteli rendszert. Áttekintette a számviteli beszámoltatás alanyait (kinek kell éves, egyszerüsített éves beszámolót készíteni, illetve mely vállalkozások mentesülnek a beszámolási kötelezettség alól) méretre és jogi formára vonatkozó kritériumok alapján, a beszámoló részeit, az alkalmazott alapelveket, a könyvvizsgálatra, illetve közzétételre vonatkozó előírásokat.

Az ACCA (Association of Chartered Certified Accountants) 2010-ben egy kilenc országra (Franciaország, Németország, Olaszország, Hollandia, Norvégia, Lengyelország, Portugália, Spanyolország és Egyesült Királyság) kiterjedő vizsgálatot folytatott a témában.

A kutatások másik iránya a KKV IFRS bevezetésére vonatkozott, az alkalmazás feltételeit, a szakma nyitottságát, a bevezetés költségei vizsgálva.

Az IFRS-ek lehetséges európai alkalmazására vonatkozó véleményeket illetően meglehetősen vegyes a kép. 
Az EFAA által 2010-ben rendezett (H. Nagy [2010]) a KKV-k beszámolójáról szóló nemzetközi konferencián ${ }^{14}$ Richard Martin (ACCA pénzügyi jelentésekért felelős vezetője) véleménye szerint a KKV-k által alkalmazható IFRS-ek meghatározó jelentőségűek az európai számvitel minőségi javításában és a tagállamok közötti számviteli harmonizációban.

A résztvevő országok képviselői részéről azonban meglehetősen változatos megjegyzések, felvetések hangzottak el. A belgák megítélése szerint az iránymutatások túl komplikáltak, holott az adminisztratív terheket jelentősen csökkenteni kellene. A francia előadó szerint az IFRS bevezetése biztosítaná a vállalkozások stabilitását és hozzájárulna versenyképességük megtartásához, ugyanakkor a becsült költségmegtakarítás mértéke meglehetősen vitatható. Javaslat hangzott el egy a mikrogazdálkodóra vonatkozóan alkalmazható „erősen egyszerüsített számviteli kimutatásrendszer" elemeire. A németek három forgatókönyvet is vázoltak a bevezetésről (európai szintü jóváhagyás, tagországi hatáskör, illetve EU direktívák modernizációja). Olaszország részéről meglehetősen tartózkodó vélemény hangzott el, amely szerint a KKV-k ügyfelei és a minősítő intézetek egyáltalán nem igénylik, hogy a KKV-k az egyszerüsített IFRS-ek alkalmazásával állítsák össze a pénzügyi beszámolóikat (előnyben részesítik a konzervatív - olasz hagyományokon alapuló beszámolókat). Meglehetősen kritikus véleménynek adtak hangot, mely szerint a standard még további egyszerüsítés után sem lesz képes a növekedés elősegítésére.

Hasonló megállapításokra jutottak az Európai Bizottság által kezdeményezett nyilvános konzultáción (Szabó [2010]), amely a standarddal kapcsolatos kezdeti reakciók, a lehetséges európai uniós alkalmazás és a számviteli irányelvek szerepére való hatások felmérésére vonatkozott. Kiderült a felmérésből, hogy bizonyos tagállamokban az adózási és tőkefenntartási szabályok rendkívül terhessé tennék egyes társaságok számára a KKV-IFRS alkalmazását, mivel megduplázná a beszámolási költségeket. A standard ellen szól annak komplexitása, valamint az, hogy az átállási költségek nagy valószínüséggel meghaladnák annak hasznát.

\footnotetext{
${ }^{14}$ A konferencia mottója „Európai kitekintés a kis- és középvállalkozások jelentései, éves beszámolóinak elkészítését érintő kihívások és nehézségek tükrében” volt.
} 
Magyarországon Kovács - Mohl [2011] végzett kutatást a témában, az ACCA és az IAAER (International Association for Accounting Education and Reseach) által kiírt pályázat $^{15}$ keretében vizsgálták, hogy bevezethetőek-e a KKV IFRS-ek és ha igen, milyen módon. Mélyinterjúk segítségével próbálták feltárni a számviteli szakma, illetve a felhasználók álláspontját. A kutatás főbb megállapításai a megkérdezettek véleménye alapján:

- egy a jelenleginél összetettebb és rugalmasabb, alapvetően háromszintü szabályrendszert javasolnak, ahol a KKV-IFRS egy alternatív, általában a nemzeti szabályozás mellett megjelenő lehetőség;

- a bevezetés legfontosabb költségtényezője a szakmai felkészítés, illetve a szükséges szabályalkotási munka (főként az adórendszer átalakítása);

- az adózás kiemelt fontosságú terület, a leginkább elöremutató egy IFRS-ek szerint kialakított, megfelelően kiigazított - nemzeti vagy EU-szinten szabályozott adóalap lenne.

Bár az európai országok részéről még meglehetősen nagy az ellenállás az IFRS SME befogadásával kapcsolatban (ez alapvetően azzal magyarázható, hogy a számviteli irányelv módosításával meg egyszerübb beszámoltatásra nyílik lehetőség) a világ más részein egyre inkább beépül az országok számviteli rendszerébe. Jelenleg mintegy 85 országban történt meg a befogadás és tobábbi 11-ben megfontolás alatt van a bevezetés. (Ifrs.org [2017])

\footnotetext{
${ }^{15}$ Magyarországon kívül Csehországra, Romániára és Törökországra terjedt ki a kutatás
} 


\subsection{KKV számvitel - nemzeti szint}

A KKV-k nemzeti szintü számviteli szabályozását Magyarország példáján keresztül mutatom be. A magyar számviteli beszámolási rendszerben megtalálható egyszerüsítési lehetőségeket tartalmazó beszámolási fajták bemutatása során kitérek a bennük rejlő könnyítésekre, vizsgálom az alkalmazók körét és az elterjedés okait.

\subsubsection{Egyszerüsített éves beszámoló}

Ez a beszámolási forma 1992-től megtalálható a magyar számviteli beszámolási rendszerben, a szabályozásában jelentősebb változás nem következett be.

Jelenleg egyszerüsített éves beszámolót készíthet az a vállalkozás, ha két egymást követő üzleti évben a következő három mutatószámból kettő a határértéket nem haladja meg:

- mérlegföösszeg 1200 millió Ft;

- éves nettó árbevétele 2400 millió Ft;

- üzleti évben átlagosan foglalkoztatottak létszáma 50 fő.

A határértékektől függetlenül nem készíthet ilyen beszámolót az Nyrt, az anyavállalatnak minősülő gazdálkodó, illetve az olyan vállalkozás, akinek kibocsátott értékpapírjainak tőzsdei kereskedelme engedélyezett.

Az alkalmazási körnél két területen is módosulás következett be az idők folyamán. Egyrészt a határértékek tekintetében

- 2001-től a létszám 100 föről 50 före csökkent;

- 2005-től a mérlegföösszeg 150 millió Ft-ról 500 millió Ft-ra, az árbevétel 300 millió Ft-ról 1 milliárd Ft-ra emelkedett;

- 2015-ben került sor az újabb módosításra (az EU irányelvnek való megfeleltetés kapcsán) és 2016-tól léptek hatályba a jelenleg érvényes határértékek.

Másrészt korábban részvénytársaság nem készíthetett egyszerüsített éves beszámolót, azonban 2011-től ez a korlátozás már csak az Nyrt-k esetében áll fenn. 
Az egyszerüsített éves beszámolót készítő vállalkozások esetén az egyszerüsítés csak a beszámoló összeállításánál figyelhető meg, de a könyvvezetésben, a szabályzatok elkészítésében és a nyilvántartási kötelezettségben nem jelent jelentősebb könnyítést.

A mérleg és az eredménykimutatás csak a föcsoportokat (nagybetűvel jelölt sorok) és a csoportokat (római számmal jelölt sorok) tartalmazza, azonban a tételeket (arab számmal jelölt sorok) nem.

Az egyszerüsített kiegészítő mellékletben bemutatandó tételek köre szükebb, mint az éves beszámoló esetén lenne. Nem kell tartalmaznia például:

- a cash flow kimutatást;

- a befektetési tükröt;

- az értékvesztések és visszaírások adatait;

- az aktív és passzív időbeli elhatárolások jelentősebb tételeit, azok időbeli alakulását;

- a képzett céltartalékot és annak felhasználását;

- az értékesítés nettó árbevételének a főbb tevékenységek szerinti bontását;

- a rendkívüli bevételek és ráfordítások részletezését (2016-tól ez az eredménykategória megszünt a magyar számviteli beszámolókban);

- a vállalkozási nyereségadó alapját módosító tételeket;

- a mérlegen kívüli jelentős kötelezettségeket.

Nincs üzleti jelentés készítési kötelezettség sem. Megenged néhány egyszerüsítést az értékelésnél, így nincs értékvesztés visszaírás, illetve a saját termelésü készleteknél megengedi a várhatóan felmerülő költségekkel és a kalkulált haszonnal csökkentet eladási áron való értékelést.

A vállalkozások jelentős része (75 \%-a) egyszerüsített éves beszámolót készít, amely azonban az adminisztratív terhek tekintetében nem jelent nagymértékü egyszerüsítést.

Az elmúlt években jelentős csökkenés következett be az alkalmazói körben, ez egyrészt a mikrogazdálkodói egyszerüsített éves beszámoló terjedésével, másrészt az egyszerűsített adózási formákat választó vállalkozások számviteli beszámolás alól való mentesítésével magyarázható. 


\subsubsection{Egyszerüsített beszámoló}

Egyszerűsített beszámolót kezdetben (1992-2003 között) az 50 millió Ft-os árbevételt el nem érő, jogi személyiséggel nem rendelkező vállalkozások (pl. bt., kkt.) készíthettek. Ez a beszámolótípus az egyszeres könyvvezetésen alapuló Egyszerűsített mérleget és Eredménylevezetést tartalmazza, nincs kötelezően elöírt kiegészítő melléklete. Azonban 2004-től profitorientált gazdálkodó szervezet már nem választhatja ezt a beszámolótípust (könyvvezetés tekintetében kötelezően át kellett térni a kettős könyvvezetésre), jelenleg csak egyéb szervezeteknek van módja ilyet készíteni, így ez részletesebben nem kerül ismertetésre.

\subsubsection{Sajátos egyszerüsített éves beszámoló}

A 2009-ben bevezetett sajátos egyszerüsített éves beszámoló készítési lehetőséget könyvvizsgálatra nem kötelezett jogi személyiség nélküli gazdasági társaságok választhattak, kezdetben méretbeli korlátozás nélkül. 2012-től itt is megjelentek a nagyságrendre vonatkozó határértékek, két egymást követő üzleti évben a következő három mutatószámból kettő nem haladta meg a határértéket:

- a mérlegföösszeg a 65 millió Ft-ot;

- az éves nettó árbevétele a 130 millió Ft-ot;

- az üzleti évben átlagosan foglalkoztatottak létszáma a 10 föt.

A sajátos egyszerüsített éves beszámoló csak (az egyszerüsített éves beszámoló szerinti) mérlegből és eredménykimutatásból állt, tehát ebben az esetben a vállalkozások mentesültek a kiegészítő melléklet készítési kötelezettség alól. Az összeállítás során bizonyos eljárások nem voltak alkalmazhatóak. Ilyen például:

- - az értékváltozás miatti terven felüli értékcsökkenés vagy értékvesztés;

- - az értékhelyesbítés használata;

- - valamint a maradványérték alkalmazása.

Bár ez a beszámolási mód már jelentősebb mértékben tartalmazott egyszerüsítési elemeket, nem terjedt el számottevő mértékben. A bevezetés évében a vállalkozások kb. 
5 \%-a választotta (Kardos [2012]), és később sem nőtt jelentős mértékben az alkalmazók aránya. Az elterjedésének egyik fő akadálya valószínüleg a társasági formában keresendő, hiszen a korábban érvényes uniós jog szerint korlátolt felelősségű társaságok nem választhatták ezt a beszámolási formát. A kft. minimális jegyzett tőkéjének 3000 eFt-ról 500 eFt-ra történő leszállítása (2007) következtében a vállalkozások jelentős része ezt a vállalkozási formát választotta, így nem volt meg a lehetősége sajátos egyszerüsített éves beszámoló készítésére.

A két legjellemzőbb társasági forma közötti választás időbeli alakulását a KSH adatai alapján készített ábra szemlélteti, amely rámutat a jegyzett tőke minimum változásának hatására.

A többi társasági forma (részvénytársaság, szövetkezet, közkereseti társaság) száma elenyésző (1 \% körül mozog), így nem került ábrázolásra.

16. ábra: Működő vállalkozások száma gazdasági forma szerint (1999-2014)

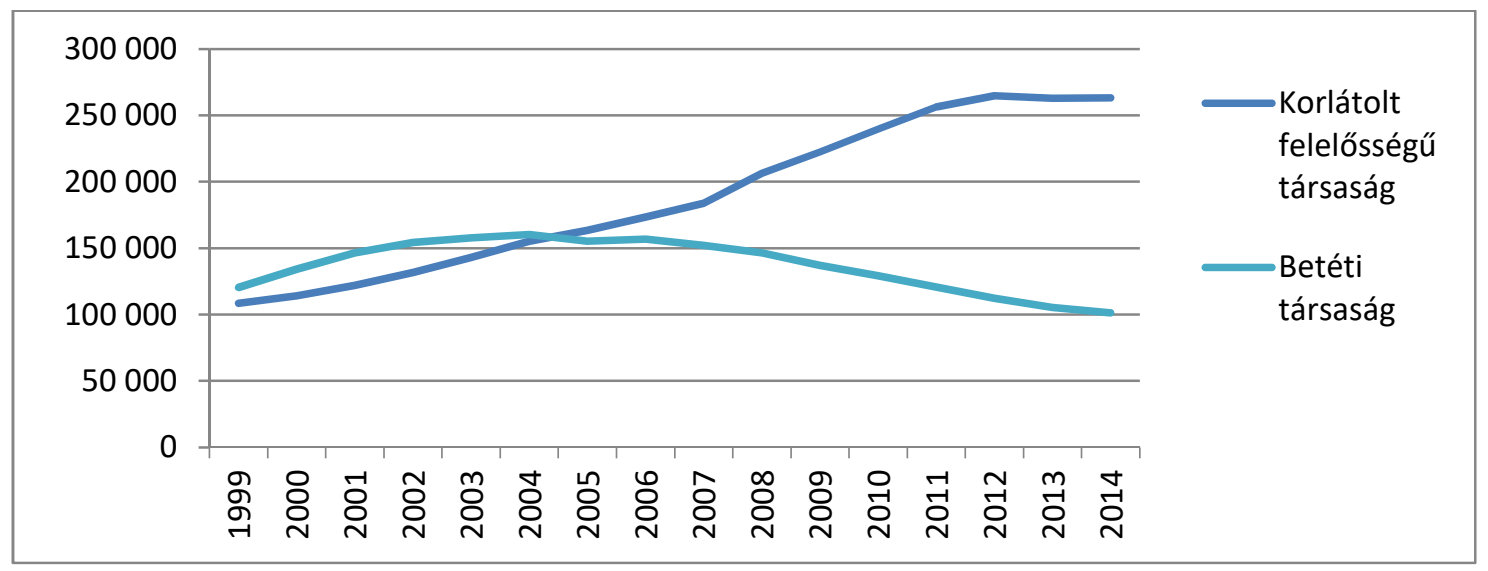

Forrás: KSH adatai alapján saját szerkesztés

A gazdasági formák közötti eltolódást különösen jól szemlélteti az újonnan alapított vállalkozások gazdasági forma szerinti vizsgálata. Látványos volt 2007 után a kft-k térhódítása és 2011-ig megfigyelhető volt az erőteljes növekedés. Ezt követően fordulat következet be, a válság utóhatásaként a vállalkozói kedv csökkenésével magyarázható a visszaesés, melyhez a szigorodó törvényi feltételek is hozzájárultak. 2014-től a kft-k esetében az alaptőke minimum újra 3 millió Ft-ra emelkedett, amelynek hatására további csökkenés figyelhető meg a cégalapítások területén. 
17. ábra: Új vállalkozások száma gazdasági forma szerint (1999-2014)

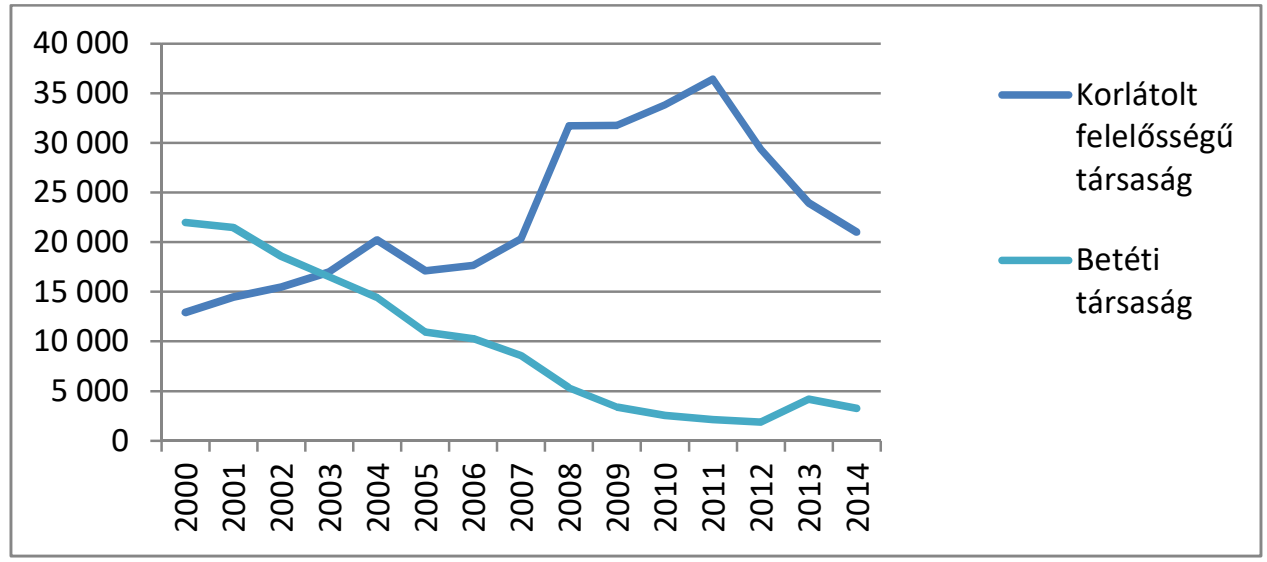

Forrás: KSH adatai alapján saját szerkesztés

Tovább szűkítették az alkalmazók körét azon betéti társaságok, akik az egyszerüsített vállalkozói adó alanyai és úgy döntöttek, hogy kizárólag az adó megállapításhoz szükséges bevételi nyilvántartást vezetik. Ez esetben ők nem kötelesek számviteli beszámolót készíteni, pedig méret alapján valószínúleg beleesnének a sajátos egyszerüsített éves beszámolót összeállítók halmazába. Az adózási formák számviteli beszámolásra gyakorolt hatásával a dolgozat későbbi részében részletesebben foglalkozom (II.4.2.5. fejezet).

Sajátos egyszerüsített éves beszámoló összeállítását utoljára a 2012-es üzleti évre vonatkozóan lehetett választani, mert ezt követően felváltotta azt a mikrogazdálkodói egyszerüsített éves beszámoló.

\subsubsection{Mikrogazdálkodói egyszerüsített éves beszámoló}

2013-tól bevezetésre került a mikrogazdálkodói egyszerűsített éves beszámoló (továbbiakban rövidítve mikrogazdálkodói beszámoló) kategória, amelynek sajátosságait a számviteli törvény alapján kormányrendelet szabályozza. ${ }^{16}$

\footnotetext{
${ }^{16}$ 308/2012 (XII. 20) kormányrendelet a mikrogazdálkodói egyszerüsített éves beszámolóról
} 
Olyan könyvvizsgálatra nem kötelezett vállalkozásnak van lehetősége ezt a beszámolási módot választani, amelynek két egymást követő üzleti évben a következő három mutatószámból kettő nem haladja meg a határértéket:

- a mérlegföösszeg a 100 millió Ft-ot;

- az éves nettó árbevétele a 200 millió Ft-ot;

- az üzleti évben átlagosan foglalkoztatottak létszáma a 10 föt.

Az alkalmazhatósági kritériumokat megvizsgálva megállapítható, hogy a kisebb méretű vállalkozások viszonylag széles körére (az elözetes számítások szerint több, mint 90 \%-a) választhatja ezt az új - az eddiginél egyszerübb szabályokat tartalmazó beszámolási lehetőséget.

A mikrogazdálkodói beszámoló kialakítása több tényezővel magyarázható, ide értve az európai uniós szabályozásváltozásokat, a magyar számviteli standardalkotási folyamatot, valamint az adminisztráció egyszerüsítésre vonatkozó törekvéseket.

Az Európai Unió 4-es irányelvének 2012. áprilisi módosításának következtében lehetőség nyílt a mikrogazdálkodók (350 ezer euró mérlegfőösszeg, 700 ezer euró árbevétel és 10 fôs létszám keretein belül) számára a korábbinál lényegesen egyszerüsített beszámoló készítésére. Az irányelv módosítása a tagállamok hatáskörébe utalja, hogy átütetik-e a nemzeti jogrendjükbe a rendelkezést.

Magyarország úgy döntött, hogy 2013-tól alkalmazza ezeket a rendelkezéseket. Elkészült az „Egyszerüsített számvitel” munkacímü standard, amelynek részletes kidolgozása után született a döntés, hogy a számviteli törvény felhatalmazása alapján kiadott kormányrendelet legyen (a magyar kodifikált jogrendszerbe nem illeszkedik a standardokkal való szabályozás).

Ez alapján mikrogazdálkodói beszámoló készítésére van lehetősége annak a számviteli törvény hatálya alá tartozó gazdálkodónak, aki könyvvizsgálatra nem kötelezett, megfelel a nagyságra vonatkozó kritériumoknak és az üzleti éve megegyezik a naptári évvel. 
A mikrogazdálkodói beszámoló egy egyszerü szabályrendszeren alapuló beszámoló. A megbízható és valós összkép követelményének úgy felel meg a mikrogazdálkodó, hogy a kormányrendelet szerinti egyszerüsítéseket kötelező alkalmaznia, nem térhet el a jogszabálytól.

A mikrovállalkozókra vonatkozó számviteli rendszerről elmondható, hogy:

- egy jól lehatárolt és szabályoknak megfelelést előíró rendszer;

- a különböző módszerek, eljárások közötti választásra nem ad lehetőséget (konkrét elöírások választások nélkül);

- rögzíti a kizárólagosan alkalmazható módszert, eljárást;

- az egyszerűsítés jegyében bizonyos fogalmak, és eljárások kizárása jellemzi;

- a rögzítések miatt számviteli politika, értékelési szabályzat nélkül is egyértelmüek a beszámoló összeállításának keretei;

- nincs szükség belső szabályzatokra (számviteli politika, értékelési szabályzat, pénzkezelési szabályzat).

A mikrogazdálkodói beszámoló (az egyszerűsített éves beszámolónak megfelelő formájú) mérlegből és eredménykimutatásból áll, kiegészítő mellékletet és üzleti jelentést nem kell készíteni.

Bizonyos vagyoni elemek nem (például az alapítás-átszervezés aktivált értéke, a kísérleti fejlesztés érteke, az üzleti vagy cégérték, az értékhelyesbítés) vagy csak korlátozottan (az időbeli elhatárolások, a céltartalékok) szerepelhetnek.

Nincsenek választási lehetőségek a fökönyvi elszámolással, az év végi értékeléssel, a mérleg és eredménykimutatás összeállításával kapcsolatban, mindezekre egyértelmủ szabályokat tartalmaz a kormányrendelet. Például:

- terv szerinti értékcsökkenést csak a társasági adótörvény ${ }^{17}$ 1-2. mellékletében meghatározott szabályok szerint lehet elszámolni (lineáris leírás, maradványérték figyelembe vétele nélkül, a társasági adótörvény szerinti leírási kulcsokkal);

- terven felüli értékcsökkenés, értékvesztés elszámolására 30 \%-ot meghaladó különbözet esetén van lehetőség (tehát nincs lehetőség a jelentőség mértékének meghatározására);

${ }^{17}$ 1996. évi LXXXI. a társasági adóról és az osztalékadóról 
- kötelező az MNB árfolyam alkalmazása, nincs év végi devizás átértékelés;

- a 100 eFt-ot meg nem haladó, 180 napja lejárt esedékességü követelést behajthatatlannak minősíti, eredmény terhére leírja;

- a feltárt hibák minden esetben nem jelentős összegü hibának minősülnek, így tárgyévi adatok között kell szerepeltetni őket (nem lehet három oszlopos mérleg, eredménykimutatás).

Mindezek az elöírások azonban azt is jelentik, hogy a megbízható és valós összkép bemutatása helyett egy szabályoknak megfelelően elkészített beszámolót kapunk.

Az egyszerüsítések által érintett területek vizsgálata (Filyó [2012]) rámutatott, hogy azok jellemzően besorolhatóak az alábbi három típus valamelyikébe:

- az adott eljárás, módszer korábban sem volt jellemző a mikrogazdálkodók jelentős részénél (ilyen például az alapítás-átszervezés aktivált értéke, a kísérleti fejlesztés aktivált értéke, az értékhelyesbítés);

- a vállalkozásnál jellemzően megjelent a vizsgált elem, de nagysága sem abszolút összegben, sem arányaiban nem bírt nagy értékkel (ide sorolhatóak az időbeli elhatárolások);

- a vizsgált módszert, eljárást a vállalkozások többsége korábban is használta, jellemzően pont a mikrogazdálkodói beszámolóban elöírtaknak megfelelően (például terv szerinti értékcsökkenés).

A mikrogazdálkodói beszámoló szabályrendszere a vizsgálat alapján nem tünik nagy változásnak a vállalkozás eddigi rendszeréhez képest, hiszen sok eleme eddig is ilyen formában volt jelen. Ugyanakkor megkönnyíti a gazdálkodók helyzetét a döntési lehetőségek eltörlésével, ezáltal egyszerübbé téve a könyvvezetést. Mindemellett abban is rejlik az előnye, hogy nincs szükség a belső szabályzatok elkészítésére és folyamatos aktualizálására, ez által jelentős mértékben csökkenti az adminisztratív terheket. 


\subsubsection{Egyszerüsített adózási formák hatása a számviteli beszámolásra}

Az adózás területén megjelenő egyszerüsített adózási formák is hatással voltak a számviteli beszámoltatás rendszerére, hiszen ennek következtében a gazdálkodók egy része kikerült a számviteli törvény hatálya alól, így nem kell számviteli beszámolót készíteniük és közzétenniük.

Az egyik ilyen adózási forma a 2003-ban bevezetésre került Egyszerüsített Vállalkozási Adó (EVA), amely az áttéréskor a korlátlan felelősséggel működő vállalkozások (bt, kkt.) számára döntési lehetőséget ad, hogy maradnak-e a számviteli törvény hatálya alatt. megfizetésével az adóalany mentesül a személyi jövedelemadó, a társasági adó és az általános forgalmi adó bevallása és megfizetése alól.

Ha kilépnek a számviteli törvény alól, bevételi nyilvántartást kell vezetniük és nem kell számviteli beszámolót készíteni. A többi vállalkozás (a maradás mellett döntők és a korlátolt felelősséggel rendelkező cégek) a kettős könyvvitel szabályai szerint köteles a könyvelését vezetni és évente számviteli beszámolót készíteni (jellemzően egyszerüsített éves beszámolót vagy mikrogazdálkodói beszámolót).

Az EVA rendszerében jelentős változás nem következett be az elmúlt 14 évben, de az adókulcs és a bevételi határérték többször emelésre került.

Az EVA vizsgálatánál megfigyelhető az adóalanyok számának mozgása. Már a bevezetés évében közel 60000 -en választották az EVA-t, melyből 25000 társas vállalkozás volt. Két év alatt 100 000-re nőtt ez a szám (kb. fele társas vállalkozás) és évekig ezen a szinten maradt. 2012-től tapasztalható erőteljes visszaesés, amely több tényezővel magyarázható:

- az EVA adókulcsának erőteljes emelése (bevezetéskor az adó mértéke 15 \% volt, amely 2006. szeptembertől 25\%-ra, 2012. januártól 37\%-ra növekedett);

- a társasági adókulcs csökkenése;

- egyéb, még kedvezőbb adózási formák (KATA, KIVA) megjelenése. 
17. táblázat: EVA alanyok számának alakulása

\begin{tabular}{|c|r|r|r|}
\hline Év & EVA alanyok száma & Egyéni vállalkozó & Társas vállalkozás \\
\hline 2011. & 90153 & 35850 & 54303 \\
\hline 2012. & 70841 & 25574 & 45267 \\
\hline 2013. & 49000 & 15000 & 34000 \\
\hline 2014. & 41000 & 12000 & 29000 \\
\hline 2015. & 36000 & 10000 & 26000 \\
\hline 2016. & 31700 & 8600 & 23100 \\
\hline
\end{tabular}

Forrás: NAV [2011] és NAV [2012-2017] alapján saját szerkesztés

A csökkenés nem állt meg. 2017-ben már kevesebb, mint 27000 EVA alany van az adóhatóság nyilvántartása szerint. NAV [2017]

A másik ilyen egyszerüsített adózási forma a 2013-ban bevezetett Kisadózók tételes adója (KATA), amelyet egyéni vállalkozók, egyéni cégek és kifejezetten csak magánszemély taggal rendelkező bt-k és kkt-k választhatnak.

Kezdetben évi 6 millió forint, majd 2017-től már 12 millió forint nettó árbevétel határig fix összeg (főállású kisadózó esetén 50000 Ft/hó) megfizetésével az adóalany mentesül a személyi jövedelemadó, a társasági adó, az szociális hozzájárulási adó és egészségügyi hozzájárulás és a szakképzési hozzájárulás bevallása és megfizetése alól.

A kiadózó vállalkozásnak bevételi nyilvántartást kell vezetnie és nem kell számviteli beszámolót készítenie.

A jelentős adminisztratív egyszerüsítést is jelentő adó rövid idő alatt nagy népszerüségre tett szert.

18. táblázat: KATA alanyok számának alakulása

\begin{tabular}{|c|r|r|r|}
\hline Év & KATA alanyok száma & Egyéni vállalkozó & Társas vállalkozás \\
\hline 2013. & 75704 & 64023 & 11681 \\
\hline 2014. & 99691 & 85868 & 13823 \\
\hline 2015. & 131597 & 115530 & 16067 \\
\hline
\end{tabular}

Forrás: Kotroczó [2016] alapján saját szerkesztés 
Továbbra is eröteljes növekedés tapasztalható, 2016-ban már több mint 175000 választották ezt az adózási formát az adóhatóság nyilvántartása szerint. NAV [2017]

Az elmúlt években megfigyelhető volt ezen egyszerüsített adózási formák terjedése, hiszen jelentős adó és adminisztratív teher csökkenést lehet elérni.

Ezen adózási formák választásával mintegy 30000 vállalkozás kikerült a számviteli törvény hatálya alól és ezáltal nincs beszámoló készítési kötelezettsége. 


\section{Számviteli politika}

A számviteli szabályozások többsége bizonyos szabadságfokkal rendelkezik, amelyet a vállalkozásoknak kell testreszabniuk a számviteli politika keretében a megbízható és valós összkép kialakítása érdekében.

A magyar számviteli törvény az alábbiak szerint fogalmaz a 14. §-ban:

„(3) A törvényben rögzített alapelvek, értékelési elöirások alapján ki kell alakítani és írásba kell foglalni a gazdálkodó adottságainak, körülményeinek leginkább megfelelö - a törvény végrehajtásának módszereit, eszközeit meghatározó - számviteli politikát.

(4) A számviteli politika keretében írásban rögzíteni kell - többek között-azokat a gazdálkodóra jellemzö szabályokat, elöírásokat, módszereket, amelyekkel meghatározza, hogy mit tekint a számviteli elszámolás, az értékelés szempontjából lényegesnek, jelentösnek, nem lényegesnek, nem jelentösnek, továbbá meghatározza azt, hogy a törvényben biztositott választási, minősitési lehetöségek közül melyeket, milyen feltételek fennállása esetén alkalmaz, az alkalmazott gyakorlatot milyen okok miatt kell megváltoztatni.”.

Az IAS 8 számviteli politikával is foglalkozó standard 5. bekezdése az alábbi tömör definíciót alkalmazza.

„A számviteli politika a gazdálkodó egység által a pénzügyi kimutatások elkészitésére és bemutatására alkalmazott sajátos elvek, alapelvek, konvenciók, szabályok és gyakorlat."

A számviteli politikai döntéseket többféle szempontrendszer szerint lehet csoportosítani. Bosnyák [2003] egyrészt a szabályozás jellege (tételes vagy szabálypontosítás), másrészt a vagyoni helyzetre (mérlegföösszeg és saját tőke), a jövedelmi helyzetre (adózás előtti eredmény) és adóalapra gyakorolt hatás szerint vizsgálta a magyar számviteli törvényben szereplő 39 számviteli politikai értékelési eljárás közötti választási lehetőséget. 
A számviteli politikai elemeket 5 szempont szerint csoportosítottam bináris skálán:

1. Információ érték:

a) csak formai, de információ tartalmat nem érintő (például a mérleg „A” vagy „B” típusa);

b) információ tartalmat érintő (az esetek többsége ide tartozik).

2. Alkalmazás jellege:

a) kötelező választás (mindenképpen el kell dönteni, hogy milyen eljárást választ a vállalkozás, például értékelésnél átlagár vagy FIFO módszer);

b) opcionális alkalmazás (abban van döntés, hogy akarják-e alkalmazni vagy nem az adott lehetőséget, például értékhelyesbítés).

3. Variációk száma:

a) korlátozott (felsorolásból kell kiválasztani, hogy melyiket választja, például összköltséges vagy forgalmi költséges eredménykimutatás);

b) megkötés nélkül (a vállalkozás szabadon dönthet, például értékcsökkenési leírás ideje ${ }^{18}$ ).

4. Választási lehetőségek közötti prioritás:

a) főszabály (az elöírások alapján javasolt megoldás);

b) alternatív megoldás (elöírások által nem preferált, de megengedett).

5. Hatás a vagyoni, jövedelmi, pénzügyi helyzetre

a) lehet rá hatással;

b) nem lehet rá hatással.

Ez utóbbi felbontható további alcsoportokra, külön-külön vizsgálva a vagyoni (mérlegföösszegre, saját tőkére), a jövedelmi (az adózás előtti eredményre, adóalap) és a pénzügyi helyzetre (például cash-flowra) gyakorolt hatásuk szerint. Abból a szempontból, hogy mire gyakorolnak hatást hierarchikusan csoportba rendezhetőek az egyes számviteli politikai döntések, mivel ami az adóalapra hatást gyakorol az adózás előtti eredményben is megjelenik, és ami az eredményre hatást gyakorol az többnyire a vagyont is befolyásolja, viszont ezek fordított irányban már nem feltétlenül érvényesek.

18 Bizonyos esetekben ez részben korlátozott lehet, például alapítás átszervezés aktivált értékének értékcsökkenése maximum 5 év (de azon belül a vállalkozás dönt). 
Ezek alapján négy csoportot lehet elkülöníteni:

0) Nincs hatása sem a vagyonra, sem az adózás elötti eredményre, sem az adóalapra (például eredménykimutatás formátuma).

1) Hatással van a vagyonra, de az adózás előtti eredményre és az adóalapra nem (például értékhelyesbítés).

2) Hatással van a vagyonra és az adózás elötti eredményre, de az adóalapra nem (például maradványérték alkalmazása).

3) Hatással van a vagyonra, az adózás előtti eredményre és az adóalapra is (például készletértékelési eljárás).

A számviteli politkai döntések lehetővé teszik a gazdálkodók számára, hogy kissé személyre (vállalkozásra) szabottabb rendszert alakítsanak ki. 


\section{AZ ALKALMAZOTT GYAKORLAT - EMPIRIKUS VIZSGÁLATOK TÜKRÉBEN}

Az alkalmazott gyakorlat bemutatását a hazai empirikus kutatások tükrében teszem meg, három témakör köré gyüjtve azokat. Kezdve a KKV-k esetében megvalósuló információs igények megjelenésével, illetve hasznosításával, ezt követi a számviteli politikában döntések meghozatalakor érvényesülő szempontok bemutatása, majd végezetül a számvitel és az adózás kapcsolatára térek ki.

\section{1. Érdekhordozók - információs igények - hasznositás}

Gyakran felmerülő kérdés, hogy kinek szól, ki használja a számviteli beszámolót. Ilyenkor a koalíciós érdekhordozói elmélet kerül elö, amely szerint egy vállalkozás a működése során számos gazdasági szereplővel (például állam, bankok, beszállítók, vevők) kerül kapcsolatba, akiknek jogos igényük, hogy a vállalkozás működését jellemző adatok nyilvánosan hozzáférhetőek legyenek, így tehát nekik szól a beszámoló.

A gyakorlati tapasztalat azonban azt mutatja, hogy a számviteli adatokat igen, de a beszámolót nem igazán használják fel (Lakatos [2009]). A KKV-kra jellemző, hogy jelentős külső érdekhordózói érdeklődésre nem tartanak számot. Alapvetően két érdekhordózó azonosítható be, aki felhasználja a számviteli adatokat. Az egyik a bankszféra (hitelfelvevő vállalkozás esetén), bár esetükben az a gyakorlati tapasztalat, hogy nem a számviteli beszámolók alapján döntenek a hitelbírálatok során, hanem saját hitelminősítési rendszereik alapján (Kovács - Mohl [2011]), a másik az állam (a vállalkozások teljes körére vonatkozóan).

Lakatos [2009] érdekhordozókra vonatkozó kutatásában az alábbi sorrendet azonosította: 1. tulajdonosok, 2. menedzsment, 3. bankok, 4. állam, 5. üzleti partnerek. Rámutatott, hogy a magyar szabályozás által előtérbe helyezett hitelezői érdek bizonyos vállalatméret alatt alig jelenik meg. 
Kántor [2010] a gazdálkodók körében folytatott empirikus kutatása (3 782 elemü kérdőíves felmérés) igazolta, hogy a számviteli információ felhasználásának célja nagyban függ a vállalkozás méretétől. A megkérdezettek $66 \%$-a tartotta fontosabbnak a könyvelési adatok elsődleges felhasználását a bevallások és beszámolók elkészítésére, mint döntéselőkészítésre. Ez az arány a kisebb vállalatoknál még inkább eltolódik, számviteli mikrovállalkozások esetén 97\%, vagyis a számviteli információk felhasználása szinte kizárólag a beszámoló összeállítására és az adóbevallások kitöltésére korlátozódik.

Kardos [2011] a beszámoló információ tartalmát, használhatóságát és megbízhatóságát vizsgáló empirikus kutatásában (amely 8 könyvelőiroda által készített 182 vállalkozásra készített beszámolóra vonatkozott) megállapította, hogy a kiegészítő mellékletek összeállítására jellemzően sablon alapján kerül sor, az előző évi adatok átírásával (tehát csak a számok kerülnek aktualizálásra). A benne található információk hasznosítása korlátozott. Kérdőíves megkérdezése alapján külső elemzők jellemzően nem használják a kiegészítő mellékletek adattartalmát, a banki szakemberek a tulajdonosra és a számviteli politika lényeges elemeire vonatkozó információkat hasznosítják.

Lakatos [2009] a pénzügyi kimutatások hasznosságáról szóló vizsgálta során kitért arra, hogy ha lenne olyan lehetőségük a vállalkozásoknak, hogy csak adóbevallást kellene összeállítaniuk és beszámolót nem, akkor élnének-e ezzel a lehetőséggel. A vélemények szélsőséges eloszlást mutattak, 40\% egyáltalán nem értett egyet, míg $24 \%$ teljesen egyetértett vele. Nagyságrendi vizsgálat alapján megállapítható volt, hogy a kisebb vállalkozások bizonyultak fogékonyabbnak a pénzügyi kimutatások elhagyásának lehetőségére. 


\section{Számviteli politika}

A számviteli politika keretében rögzíteni kell a vállalkozásra jellemző szabályokat, módszereket, eljárásokat (természetesen a számviteli törvény által megengedett kereteken belül), ezáltal egyénre (vállalkozásra) szabni azokat.

A gyakorlat azonban sokszor azt mutatja, hogy ez az egyedi formálás nem igazán valósul meg a számviteli politika kialakítása során, főként a kisebb vállalkozások esetén nem jelennek meg a sajátosságok.

Ezt támasztja alá Filyó - László - Mikáczó [2011] mérlegképes könyvelők körében végzett kérdőíves felmérése (765 elemszámú minta), amely szerint a válaszadók 59\%-a könyvelt már olyan cégnek, amelynek a számviteli politikája még nem készült el. A számviteli politika kialakításának módjára vonatkozó válaszok szerint az a cégvezetéssel közösen történt 26\%-ban, a könyvelő önállóan a cégtől függetlenül készítette el 32 \%-ban, a könyvelő mástól kapott mintát használva készítette el 30\%ban, a cég vezetése készítette el a könyvelő közremüködése nélkül 5\%-ban, a fennmaradó résznél még nem készítették el a számviteli politikát.

Deák [2006] rámutat, hogy a számviteli előírások a mérlegképesség, az értékelés és a bemutatás területén is számos diszpozitív jellegű elöírást tartalmaznak, amelyek megfelelő mozgásteret biztosítanak a vállalkozásoknak a megbízható és valós összkép testreszabott kialakításához. Megállapítja ugyanakkor, hogy az általa vizsgált vállalkozások (100 kis és közepes méretü vállalkozásra vonatkozó, kérdőíves lekérdezés) alapvetően sematikus, sablonszerü módszereket alkalmaznak, az elöírásokból következő minimális elvárások teljesítésére törekszenek.

A mérlegképességhez kapcsolódóan vizsgált tételek (alapítás-átszervezés aktivált értéke, kísérleti fejlesztés aktivált értéke, értékhelyesbítések, céltartalék jövőbeni költségekre) nem játszanak mérvadó szerepet a vizsgált vállalkozások életében. Az értékelésre vonatkozó válaszok tükrözik, hogy nagyon standard megoldásokat választanak, például az értékcsökkenésnél a lineáris leírást (97\%) alkalmaznak, a készletek esetén nem vezetnek év közben nyilvántartást (90\%), a devizás tételeknél az MNB árfolyamot (95\%) választják. A beszámolásra, bemutatásra vonatkozóan mindenki a megengedett legegyszerübb formát választja, senki nem él a 
kötelezőn túli tagolási lehetőségekkel. A számviteli információs rendszer értékelése alapján megállapította, hogy a vállalkozásoknál elsődleges szempont az egyszerüsítésre törekvés és az adóterhelés minimalizálása, a számviteli információk döntéshozatalhoz való felhasználása másodlagos.

Bosnyák [2003] vizsgálata, amely az alkalmazott számviteli értékelési eljáráskombináció kialakításakor érvényesülő szempontokra terjed ki, megállapította, hogy eltérés mutatható ki a vállalatméret függvényében. A kisebb vállalkozásoknál az adózás, a nagyobb vállalkozások esetén a számviteli információkkal kapcsolatos megfontolások erőteljesebb hatását igazolta.

A mikro és kisvállalkozásokra vonatkozóan a vállalati minta és a könyvvizsgálói vélemények is alátámasztották, hogy az értékelési eljárások kiválasztását leginkább befolyásoló tényezők az adózáshoz, illetve adóellenőrzéshez kapcsolódóak. Kiemelt befolyásoló tényezők:

- az adókedvezmények maximális kihasználási lehetőségének biztosítása;

- a társasági nyereségadó törvény és a számviteli törvény szerinti adatszolgáltatáshoz szükséges nyilvántartások egységesítése, az adótörvény rögzített értékelési eljárásainak alkalmazása;

- adóellenőrzés során az értékelési eljárás-kombinációt, annak egyes elemeit megfelelőnek találják a revizorok.

Megállapította, hogy az egyes értékelési eljárások között választásoknál, azok társasági adóalapot befolyásoló volta miatt, tényleges gazdasági előnyt vagy hátrányt hordozó döntési változót látnak. Az értékelési eljárás-kombinációk kialakításakor a társasági adózással kapcsolatos megfontolások szignifikáns szerepét a megbízható és valós összkép érvényesülését veszélyeztető jelenségként lehet azonosítani. 


\section{Számvitel és adózás kapcsolata}

Magyarországon a számvitel és az adózás kapcsolata - hasonlóan a kontinentális európai országok jelentős részéhez (például Németországhoz) - meglehetősen szoros. A vállalkozások, föként a KKV-k, a számviteli beszámolóinak összeállítása során elsősorban adózási-adóoptimalizálási szempontok dominálnak.

Az adózás kiemelt, számvitelt megelőző szerepe, a vállalkozások életében több szempontból is megmutatkozik a müködésük folyamán. Ez megfigyelhető egyrészt a két terület megítélésében a vállalkozás vezetői részéről, másrészt a számviteli döntések, választások során is.

Kántor [2010] kutatása rámutat, hogy a vállalkozások vezetői, menedzsmentje részéről egyre növekvő az igény, hogy a számviteli feladatokat ellátó személy (osztály, csoport) elsősorban az évközi, folyamatos adóbevallási kötelezettségek teljesítésére koncentráljon, csak ezt követően az adott üzleti évröl szóló számviteli beszámoló elkészítésére. Az egyre szigorodó adózási szabályok következtében a vállalkozások (gazdálkodó egységek) célja az adóhatóságok által elvárt adatszolgáltatások, adóbevallások és adóbefizetések maradéktalan teljesítése. Igyekeznek minél inkább elkerülni az esetleges ellenőrzéseket, minimalizálni a büntetéseket, bírságokat. Az adóbevallások helyességének igénye a számviteli beszámolóval szemben mikrovállalkozásoknál 98 vs. $2 \%$, nagyvállalkozás esetén 50 vs. $50 \%$.

Lakatos [2009] a számviteli politika megválasztása és az adózás kapcsolatát vizsgálva megállapította, hogy a nagyobb vállalkozások nagyobb valószínüséggel térítik el az adóalapjukat adózás előtti eredményüktől olyan adóalap korrekciókkal, amelyek alkalmazása és nagyságrendje nagyrészt a vállalkozás döntése. 


\section{A KUTATÁS HIPOTÉZISEI}

Az előző fejezetekben bemutatásra került a kis- és középvállalkozások számviteli beszámolási rendszere elméleti és gyakorlati szinten, áttekintve a felmerülő információigényeket, az érdekhordózói kört, az adóval való szoros kapcsolatot és a pénzügyi kimutatások hasznosságának megítélését.

A kis- és középvállalkozások számviteli beszámolási rendszerének értékelésekor leggyakrabban a felmerülő információigények, az érdekhordózói kör, az adóval való szoros kapcsolat és a pénzügyi kimutatások hasznosságának megítélése kerül a vizsgálat fókuszába. Napjainkban azonban egyre inkább előtérbe kerül az egyszerüsítési lehetőségek dimenziója mind a szabályozás mind a gyakorlat szintjén.

Ezekből kiindulva vizsgáltam a kis- és középvállalkozások számviteli politikáját. Feltételezésem szerint az egyszerüsítési törekvések már eddig is megjelentek, amelyet kétféle döntési szituáció vizsgálatával kívántam alátámasztani:

- Az egyik azon esetekre vonatkozik, amikor többféle variáció közül választhat a vállalkozó (például az értékcsökkenési leírások módszere). Azt feltételeztem, hogy ilyenkor a legegyszerübb megoldást választják (például lineáris leírási mód, ami megegyezik a társasági adó által elismert mértékkel).

- A másik döntési szituációban, amikor csak lehetőség van az alkalmazásra, de nem kötelező (például értékhelyesbítés, valós értékelés, alapítás-átszervezés értékének aktiválása), feltételezésem szerint inkább nem élnek a választás lehetőségével.

H1 hipotézis: Magyarországon a kisebb vállalkozások a számviteli politikájuk kialakítása során nagyobb arányban választanak egyszerübb megoldásokat a nagyobb vállalkozásokkal összehasonlítva.

H2 hipotézis: Magyarországon a kisebb vállalkozások kevésbé élnek azokkal a számviteli politikai választási lehetőségekkel, amelyek alkalmazása nem kötelező. 
A kutatás másik iránya a számvitel és az adózás kapcsolatának szorosságára vonatkozik. Feltételezésem szerint a kisebb vállalkozások a számviteli rendszerüket alárendelik az adózásnak, úgy alakítják, hogy minél kisebb legyen az eltérés a számviteli érték és az adózás által elismert érték között, amelynek következtében kevesebb korrekcióra van szükségük az adó megállapításánál.

H3 hipotézis: Magyarországon a kisebb vállalkozásoknál a számviteli (adózás előtti eredmény) és az adózási (adóalap) jövedelemértelmezésben kisebb a relatív eltérés.

H4 hipotézis: Magyarországon a kisebb vállalkozásoknak szignifikánsan kevesebb adóalap módosító tétele van a nagyobb vállalkozásokkal összehasonlítva.

A kutatás harmadik iránya egy nemzetközi kitekintés. Feltételezem, hogy a KKV-k számviteli beszámolására vonatkozó szabályozásban eltérések tapasztalhatóak, és ezek alapján a nemzetek csoportokba rendezhetőek.

H5 hipotézis: Az egyes országok csoportokba rendezhetőek a KKV-ra vonatkozó számviteli szabályozásuk alapján. 


\section{A FELHASZNÁLT MÓDSZEREK ÉS A VIZSGÁLT ADATBÁZISOK}

A hipotézisek teszteléséhez 5 adatbázist használtam fel, ebből egy (TAO) külső forrásból származott, a többi saját előállítás nyilvánosan hozzáférhető cégadatok alapján (KV, NV), mélyinterjú közben gyüjtött információkra támaszkodva (KI), illetve egy nemzetközi kutatás adatainak felhasználásával (NK).

\section{Kisebb vállalkozások adatbázisa (AB:KV)}

A H1 és a H2 hipotézis tesztelését egyedi vállalati beszámolók kiegészítő mellékletének vizsgálatával végeztem el. Kisebb vállalkozásnak az egyszerüsített éves beszámolót készítő vállalkozásokat tekintettem. A cégnyilvántartás adatbázisában a Magyarországon bejegyzett müködő vállalkozásokból társasági forma szerinti szürésben kiemeltem a betéti társaságokat és a korlátolt felelősségü társaságokat (a részvénytársaságokat a nagyobb vállalkozások adatbázisához használtam, a többi társasági forma alacsony gyakorisága nem indokolta a vizsgálatba való bevonást) és ezekre rétegzett egyszerü véletlen mintavételt alkalmaztam.

Ez alapján a 100 elemủ adatbázis létrehozásához 73 kft. és 27 bt. adataira volt szükségem. Az vizsgálatba a 2012. évi nyilvánosan közzétett (e-beszámoló) számviteli beszámolókat vontam be. A teljes minta elöállításához kft-k esetében 110, bt-k esetében 49 vállalkozás kiválasztására volt szükség, ugyanis 62 esetben nem felelt meg cég a mintába kerülés feltételrendszerének. A kimaradás oka volt többek között, ha a vállalkozás nem töltötte fel beszámolóját, nem teljes naptári évre vonatkozott a beszámoló, más típusú beszámolót készített pl. sajátos egyszerüsített éves beszámolót (nincs kiegészítő melléklet).

\section{Nagyobb vállalkozások adatbázisa (AB:NV)}

A H1 és a H2 hipotézis teszteléséhez szükséges nagyobb vállalkozások adatbázisba kerülés kritériuma az éves beszámolót készítés volt. A cégnyilvántartási adatbázisban egyetlen olyan szürési feltétel volt, amely alapján feltételezni lehetett, hogy éves beszámolót készít a vállalkozás - ez pedig a részvénytársasági forma. Bár 
2009 óta a zrt-k választhatnak egyszerübb beszámolási formát, még mindig ebben a vállalkozói körben a legelterjedtebb az éves beszámoló.

Az adatbázishoz szükséges 30 elemszám eléréséhez végül 57 cég egyszerü véletlen mintavétel szerinti kiválasztása volt szükséges, a kimaradás fő oka az egyszerüsített éves beszámoló készítés, illetve a nem teljes naptári évre vonatkozó beszámoló volt.

\section{Könyvelő irodák adatbázisa (AB:KI)}

A H1 és a H2 hipotézisek ellenőrzésére a kiegészítő mellékletek vizsgálata mellett könyvelöirodák adatait használtam fel. 15 könyveléssel foglalkozó cég vezetőjével készítettem nem strukturált mélyinterjút, amelynek keretében a teljes ügyfélkörükről (összesen 493 vállalkozásról) rendelkezésemre bocsátottak információkat a számviteli beszámolás módjára, a tevékenységi körre, az alkalmazott számviteli politika kialakítására és főbb elemeire vonatkozóan, amelyeket adatbázisba foglaltam.

\section{5. évi Társasági adó adatbázis (AB:TAO)}

A H3 és a H4 hipotézis teszteléséhez a Nemzeti Adó- és Vámhivatal valamint a Budapesti Corvinus Egyetem közötti együttmüködési megállapodás keretében rendelkezésre bocsátott 2015. évi társasági adóbevallások adatbázisát használtam fel. Az adatbázisban a Magyarországon 2015. üzleti évre társasági adó bevallást benyújtó 420523 gazdálkodó egység adatai szerepelnek azonosító nélkül.

Az elemzéshez a vállalkozásokat három kategóriába soroltam a számviteli beszámoló fajtáját meghatározó három méretkategorizáló paraméter (mérlegfőösszeg, értékesítés nettó árbevétele, létszám) alapján. A besoroláshoz szükséges, hogy mindhárom adat rendelkezésre álljon, ezért szükség volt a hiányzó értékek kezelésére. Hiányzó mérlegföösszeg, árbevétel vagy létszám esetében nullának tekintettem azok értékeit. A beszámolókészítésre vonatkozó határértékek alapján besoroltam a cégeket a Mikrogazdálkodói beszámoló - Egyszerüsített éves beszámoló - Éves beszámoló kategóriába. 


\section{Nemzetközi adatbázis 1 (AB:NK)}

A H5 hipotézis ellenőrzéséhez felhasználtam az Európai Bizottság által 2011ben végeztetett kutatás adatait (CNA Interpreta S.r.1.[2011]: Study on Accounting requirements for SMEs), amely 20 országra kiterjedően - 19 EU tagállam és Norvégia vizsgálta a KKV-k számviteli rendszerét. A kutatásban vizsgált országok: Ausztria, Belgium, Csehország, Dánia, Észtország, Franciaország, Hollandia Görögország, Lengyelország, Litvánia, Nagy-Britannia, Németország, Norvégia, Olaszország, Portugália, Románia, Spanyolország, Svédország, Szlovákia, Szlovénia. A tanulmányból kigyüjtöttem a számviteli beszámoltatás rendszerét jellemző adatokat (beszámoló felépítése, határértékek, közzététel, könyvvizsgálat) az egyes országokra vonatkozóan. Az eredeti kutatásban nem szerepelt Magyarország, így az adatbázist kiegészítettem a hazánkra vonatkozó adatokkal.

Az adatok feldolgozása és elemzése az IBM SPSS 22 programcsomagjával történt, amelynek használatát a Budapesti Corvinus Egyetem tette lehetővé. A vizsgálat során a statisztikai alapmüveleteken túlmenően többváltozós statisztikai módszereket (varianciaanalízist, klaszterelemzést) is alkalmaztam. 


\section{A FELÁLLÍTOTT HIPOTÉZISEK ELLENŐRZÉSE}

A felállított hipotéziseket a bemutatott adatbázisokon teszteltem. Szükség esetén egy-egy hipotézis vizsgálatához több adatbázist is felhasználtam. A vizsgálatoknak alapvetően három iránya volt, ezért az összefüggő hipotézisek vizsgálatát együtt végeztem el.

\section{Számviteli politikai döntések vizsgálata (H1-H2)}

Feltételezésem szerint a vállalkozások számvitellel kapcsolatos egyszerüsítési törekvései a számviteli politikai döntések szintjén is megfigyelhetőek. A számviteli törvény által nyújtott választási lehetőségek közül jellemzően az egyszerübb megoldást választják, ha pedig nem kötelező az alkalmazás, akkor nem használják azt. A két eset vizsgálata a vállalkozás méretével való kapcsolatra is kiterjedt.

H1 hipotézis: Magyarországon a kisebb vállalkozások a számviteli politikájuk kialakítása során nagyobb arányban választanak egyszerübb megoldásokat a nagyobb vállalkozásokkal összehasonlítva.

Ezen hipotézis tesztelése során azon döntési szituációkat vizsgáltam, ahol a lehetséges variációk közül mindenképpen kiválasztásra kerül valamilyen megoldás, módszer. Ide sorolom az alábbi számviteli politikai döntéseket:

- befektetett eszközök értékcsökkenésével kapcsolatos döntések (leírási mód, leírási kulcs, maradványérték meghatározása);

- kis értékü tárgyi eszközök kezelése;

- készletnyilvántartás módja;

- készletértékelés módja;

- választott devizaárfolyam;

- költségelszámolás módja;

- eredménykimutatás formája. 
A kiválasztásnál figyelembe vettem a Mikrogazdálkodói beszámolóira vonatkozó kormányrendelet elöírásait, amelyben ezen területekre vonatkozóan rögzítésre került az alkalmazható módszer.

- Tárgyi eszközök és immateriális javak esetén bruttó érték alapján számított, lineáris, időarányos módszer alapján kell meghatározni a terv szerinti értékcsökkenést, a társasági adó megállapításánál figyelembe vett kulcsokkal, maradványérték nem állapítható meg.

- Kis értékü (100 eFt egyedi bekerülési értéket el nem érő) eszközök értékcsökkenését egy összegben kell elszámolni. ${ }^{19}$

- Készletekről nem vezet nyilvántartást, a készlet értékelése az utolsó beszerzési ár alapján történik. ${ }^{20}$

- Költségnem elszámolás.

- Összköltséges eredménykimutatás.

Ezen eljárásokat és módszereket tekintem egyszerübb megoldásnak.

\section{H2 hipotézis: Magyarországon a kisebb vállalkozások kevésbé élnek azokkal a} számviteli politikai választási lehetőségekkel, amelyek alkalmazása nem kötelező.

Ebbe a kategóriába (nem kötelező az alkalmazás) a következő számviteli politikai döntéseket soroltam:

- alapítás - átszervezés értékének aktiválása;

- kísérleti fejlesztés értékének aktiválása;

- értékhelyesbítés alkalmazása;

- céltartalék képzés jövőbeni költségekre;

- devizakötelezettség nem realizált árfolyamveszteségének elhatárolása;

- valós értékelés alkalmazása.

A Mikrogazdálkodói beszámolóra vonatkozó szabályozás filozófiája ezeket az elemeket nem engedi alkalmazni, tehát tiltja a használatukat.

\footnotetext{
19 Az értékhatár lefelé eltérhet, ennek tényét külön fel kell tüntetni.

${ }^{20}$ Ha vezet készletnyilvántartást, akkor külön fel kell tüntetni és készlet nyilvántartási szabályzatba kell foglalni a készletek nyilvántartásával, értékeléssel kapcsolatos szabályokat.
} 
A hipotézisek teszteléséhez kiindulásként az AB:KV és az AB:NV adatbázisokat használtam, amelyek a cégadatbázisból egyszerü véletlen mintavétellel kiválasztott vállalkozások nyilvánosan közzétett Egyszerüsített éves beszámolóját (100), illetve Éves beszámolóját (30) tartalmazták. A vizsgálat fókuszában a 2012-es év állt. Ennek oka, hogy a mikrogazdálkodói egyszerüsített éves beszámoló bevezezését megelőzően állapotot szerettem volna áttekinteni, hogy elemezni tudjam a bevezetés hatásait.

A vizsgálatot a kiegészítő mellékletek elemzésével végeztem, amely a számviteli törvény elöírása alapján (88. § (3)) elvileg tartalmazza a számviteli politika meghatározó elemeit, azok változását és a változás eredményre gyakorolt hatását. A kiegészítő mellékletnek nincs kötött formátuma, a tartalmára vonatkozóan a számviteli törvény 88 . - 94. § szabályai érvényesek.

Meglehetősen eltérő színvonalú és adattartalmú kiegészítő mellékletekkel találkoztam a vizsgálat folyamán. A nagyobb vállalkozások esetében jobban megfigyelhető volt a törvényi elöírásoknak való megfelelés. A kisebb vállalkozások kiegészítő melléklete nagyon vegyes képet mutatott. Kigyüjtöttem a vizsgált számviteli politikai döntésekre vonatkozó információkat, illetve jelöltem, ha nem volt feltüntetve az adott területtel kapcsolatosan semmi, ami alapján beazonosítható lett volna az alkalmazott kategória. Az így keletkezett adatbázison végezetem el az elemzést, ahol vizsgáltam az alaphelyzetnek feltételezett (egyszerübb megoldás, illetve nem alkalmaz) szituációtól való eltérést.

A kiegészítő mellékletek vizsgálata alapján már kimutatatható volt a különbség a kisebb és nagyobb vállalkozások számviteli politikai döntései között, a terület mélyebb vizsgálata érdekében azonban kiterjesztettem a kutatást a számviteli beszámolót elkészítőkre. A kisvállalkozások esetében ezt a személyt jellemzően nem a cégen belül kell keresni, hiszen a vállalkozások könyvelését ezek a vállalkozások javarészt külső könyvelöre bízzák. Ezért döntöttem úgy, hogy könyvelőirodákat keresek meg és a tőlük szerzett információk birtokában folytatatom a vizsgálatot. 
A kérdőíves felmérést hosszas mérlegelés után elvetettem. Két oka volt, hogy nem ezt az adatgyüjtési módszert alkalmaztam:

- a környezetemben korábban lezajlott tanszéki kutatások esetén tapasztalt kiábrándítóan alacsony visszaküldési arány (Bosnyák János kutatásánál 3\%, Lakatos László Péterénél 1,5\%);

- a kérdőíves felmérések azon korlátozottsága, hogy nincs lehetőség a kapott válaszok mögöttes okainak feltárására, illetve az esetleges értelmezésbeli különbségek tisztázására.

Ezen megfontolások alapján végül a mélyinterjús vizsgálat mellett döntöttem, könyvelőirodák vezetőit kerestem meg és a velük való beszélgetésekre alapozva folytattam a kutatást.

A vizsgálatba 15 könyvelőirodát vontam be (12 budapesti és 3 vidéki), az ügyfélkör nagyságát tekintve elég vegyes képet mutattak (a legkisebb ügyfélszám: 1, a legnagyobb: 89), az alkalmazotti létszám pedig egytől ötig terjedt. A cégek kiválasztása nem véletlenszerüen történt, hanem kapcsolatrendszeri úton (ismeretlenül felkeresve könyvelő irodákat, kicsi eséllyel jutottam volna hozzá ilyen mélyen a kapott információkhoz). A kutatás nem reprezentatív, célja a mögöttes okok feltárása volt. A vizsgálatot a teljes (számviteli beszámolót készítő) ügyfélkörre kiterjesztettem, ennek következtében 493 vállalkozásra vonatkozóan jutottam információhoz 21 db éves beszámolót, 368 egyszerüsített éves beszámolót és 104 mikrogazdálkodói beszámolót készítő vállalkozás került a mintába.

Első lépésként „kérdőív” (3. melléklet) formájában adatokat kértem a könyvelőirodától, ami alapján felkészültem a (nem strukturált) interjúkra. Az így rendelkezésemre álló adatok a következőek voltak:

- a készített számviteli beszámoló száma és típusa (2012 és 2013);

- számviteli politika meghatározója (vállalkozás, könyvelő, közösen);

- a különféle számviteli politikai döntések alapján a vállalkozások megoszlása;

- a számviteli egyszerüsítések alkalmazására vonatkozó kérdés (attitüd).

Ezt követően folytattam le a beszélgetéseket a könyvelö irodák vezetőivel, amelynek során megismertem az általuk könyvelt vállalkozások összetételét tevékenységi kör szempontjából is. Feltárásra kerültek mindkét hipotézishez 
kapcsolódóan az eltérést mutató cégek esetében az okok, amelyek miatt az adott számviteli politikai döntés született. A beszélgetések alapján lehetőségem volt elkülöníteni azon vállalkozásokat, amelyeknél a vizsgált terület nem volt releváns, mert a vállalkozás nem rendelkezett az adott vagyoni elemmel. Így egy tisztított adatbázis létrehozására is lehetőségem volt, ami még jobban rámutat a döntésekre, hiszen csak azon vállalkozásokra tartalmaz adatot, ahol létjogosultsága volt az adott számviteli politikai döntésnek. A mikrogazdálkodói beszámolót készítőkre vonatkozó adatokat nem különítettem el az egyszerüsített éves beszámolót készítőktől, mert szerettem volna a beszámolókból nyert adatokkal összehasonlíthatóvá tenni a szerkezetet. A beszámolók esetén vizsgált 2012-es évben még alapvetően ők is egyszerüsített éves beszámolót készítettek, így kerültek ide besorolásra.

A beszélgetések rávilágítottak, hogy a számviteli politika kialakítása kis cégek esetén jellemzően a könyvelőre hárul, jó esetben közösen a vállalkozás vezetésével történik. Ezzel szemben a nagyobb cégek esetén jellemzö, hogy maga a cég alakította ki a számviteli politikáját, vagy ha leányvállalatról volt szó, mert ilyenkor az anyavállalat határozta meg a követendő irányelveket.

A könyvelőirodák sok esetben séma alapján készítik a számviteli politikát („vásárolt modell”), amelyet jellemzően rászabnak az adott vállalkozásra. Standardizált formákat használnak a szabályzatok elkészítése során.

2017 elején a könyvelöirodákat újra megkerestem, hogy az időközben bekövetkezett változásokat lekövessem. Kiderült, hogy az ügyfélszám növekedésén kívül (562-re emelkedett az általuk összeállított beszámolók száma, melyből 18 éves, 394 egyszerúsített éves, 150 mikrogazdálkodói beszámoló) az elvekben nincs jelentős módosulás, ezért az eredeti gyüjtés adatait használtam a hipotézisek ellenőrzésénél.

A továbbiakban bemutatom a vizsgálat eredményeit, első körben röviden ismertetem a területhez kapcsolódó szabályozást, majd az empirikus kutatás eredményeit, kezdve a beszámolók vizsgálata alapján nyert információkkal és végül a könyvelőirodák interjúi alapján próbálok a mélyebb összefüggésekre, mögöttes tartalmakra rávilágítani. 
Terv szerinti értékcsökkenés meghatározására vonatkozó döntések

A gazdálkodó egység a tárgyi eszközök és az immateriális javak esetében az amortizációs politikájának keretében dönt az értékcsökkenési leírás módszeréből, leírási kulcsról, maradványérték megállapításáról, kis értékủ tárgyi eszközök kezeléséröl. (Szt. 52. §)

A számviteli beszámolókból nyert adatok azt mutatták, hogy a vállalkozások kivétel nélkül lineáris leírást alkalmaznak. A leírási kulcs meghatározásánál jellemzően a „gazdaságilag hasznos élettartam hosszára vetítve határozzák meg a leírási kulcsot” megjegyzés szerepel (ahogy azt a számviteli törvény szabályozza), ez azonban nem jelenti egyértelmủen, hogy a társasági adó törvénytől eltérő volt a kulcs. Csak azokat a vállalkozásokat soroltam a TAO szerinti kulcsba, ahol egyértelmủen megállapítható volt (leírták vagy az adóalap korrekciókból látszott, ez utóbbi vizsgálatára, csak az éves beszámolót készítő vállalkozások esetén volt lehetőségem, mert náluk a kiegészítő melléklet része az adóalap levezetésére vonatkozó számítás), így a TAO-tól eltérő kulcsot alkalmazók aránya torzítást tartalmazhat.

A maradványérték alkalmazását szintén a számviteli törvény írja elö, így a szövegben jellemzően ez köszönt vissza, ugyanakkor kérdés, hogy ténylegesen használják-e a vállalkozások vagy nem jelentősnek minősítik és nullának tekintik. A nem jelentős maradványérték nagyságára vonatkozóan meglehetősen eltérő értékeket találtam a kiegészítő mellékletekben (húszezer és egymillió forint közötti intervallumban).

Kis értékü tárgyi eszköz esetén a törvény lehetőséget biztosít az egyösszegü értékcsökkenés elszámolására (adminisztratív könnyítés jegyében), 100 eFt-ban szabja meg a határértékét, de a cég dönthet más (kisebb) érték alkalmazásáról. Ahol eltérést tapasztaltam egy esetben 200 eFt szerepelt megadva (amely nem felel meg a számviteli törvénynek), a többi esetben 50 eFt (ez volt korábban - 2006 előtt - a kis értékü tárgyi eszköz határértéke). Ez utóbbi esetekben felvetődhet a kérdés, hogy valóban ezt a határértéket alkalmazza a cég, vagy csak nem frissítette le a szabályzatait.

Összességében elmondható, hogy az értékcsökkenés vizsgálatánál nem figyelhető meg lényeges különbség a kisebb és nagyobb vállalkozások esetében. A 
tisztán látást azonban nehezíti, hogy az egyszerüsített éves beszámolót készítő vállalkozásoknál sok esetben nincs információ. Ezért további vizsgálatokat hajtottam végre a könyvelőirodák adatbázisán.

19. táblázat: Tárgyi eszközökre vonatkozó számviteli politikai döntések - beszámolók

\begin{tabular}{|c|c|c|c|c|c|c|}
\hline \multirow{2}{*}{$\begin{array}{l}\text { Beszámoló } \\
\text { típusa }\end{array}$} & \multicolumn{6}{|c|}{ Számítási módszer } \\
\hline & lineáris & \multicolumn{2}{|c|}{ lineáristól eltérő } & \multicolumn{2}{|c|}{ eltérök aránya } & nincs említés \\
\hline$\overline{E E ́}$ & 81 & \multicolumn{2}{|c|}{0} & \multicolumn{2}{|c|}{$0,0 \%$} & 19 \\
\hline ÉB & 30 & \multicolumn{2}{|r|}{0} & \multicolumn{2}{|r|}{$0,0 \%$} & 0 \\
\hline Összesen & 111 & \multicolumn{2}{|r|}{$\mathbf{0}$} & \multicolumn{2}{|r|}{$0,0 \%$} & 19 \\
\hline \multirow{2}{*}{$\begin{array}{c}\text { Beszámoló } \\
\text { típusa }\end{array}$} & \multicolumn{6}{|c|}{ Leírási kulcs } \\
\hline & TAO szerinti & \multicolumn{2}{|c|}{ TAO-tól eltérő } & \multicolumn{2}{|c|}{ eltérók aránya } & nincs említé \\
\hline EÉ & 21 & \multicolumn{2}{|r|}{41} & \multicolumn{2}{|r|}{$66,1 \%$} & 38 \\
\hline ÉB & 6 & \multicolumn{2}{|r|}{19} & \multicolumn{2}{|r|}{$76,0 \%$} & 5 \\
\hline Összesen & 27 & \multicolumn{2}{|r|}{60} & \multicolumn{2}{|r|}{$69,0 \%$} & 43 \\
\hline \multirow{2}{*}{$\begin{array}{c}\text { Beszámoló } \\
\text { típusa }\end{array}$} & \multicolumn{6}{|c|}{ Maradványérték } \\
\hline & nincs & \multicolumn{2}{|l|}{ van } & \multicolumn{2}{|c|}{ eltérók aránya } & nincs említés \\
\hline É́ & 5 & & 40 & & $88,9 \%$ & 55 \\
\hline ÉB & 3 & 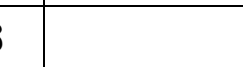 & 16 & & $84,2 \%$ & 11 \\
\hline Összesen & $\varepsilon$ & 3 & 56 & & $87,5 \%$ & 66 \\
\hline & & & s értél & xü leírá & & \\
\hline $\begin{array}{l}\text { Beszamoio } \\
\text { típusa }\end{array}$ & $\begin{array}{l}\text { alkalmazza } \\
(100 \mathrm{eFt})\end{array}$ & $\begin{array}{c}\text { alkalmazza } \\
\text { (más összeg) }\end{array}$ & $\begin{array}{r}\mathrm{n} \\
\text { alkal }\end{array}$ & mazza & $\begin{array}{l}\text { eltérók } \\
\text { aránya }\end{array}$ & $\begin{array}{l}\text { nincs } \\
\text { említés }\end{array}$ \\
\hline EÉ & 72 & 1 & & 1 & $2,7 \%$ & 26 \\
\hline ÉB & 25 & 3 & & 0 & $10,7 \%$ & 2 \\
\hline Összesen & 97 & 4 & & $\overline{1}$ & $4,9 \%$ & 28 \\
\hline
\end{tabular}

Forrás: Számviteli beszámolók adatai alapján saját szerkesztés

A könyvelöirodák esetében először elkülönítettem azon vállalkozásokat, amelyeknél nem jelent meg tárgyi eszköz, illetve immateriális jószág, tehát az értékcsökkenés területe irreleváns volt a vállalkozás számára (10 esetben jelezték, hogy semmilyen tárgyi eszközzel rendelkezik a vállalkozás, további 54 esetben csak kis értékü tárgyi eszköze volt a vállalkozásnak, amit egy összegben, azonnal elszámoltak 
költségként. Érdekesnek tünhet az ÉB esetén tárgyi eszközzel nem rendelkező vállalkozás, erről azonban kiderült, hogy konszolidáció miatt készít éves beszámolót (határértékek alapján nem lenne rá szükség), jelenlegi tevékenysége nem igényli a tárgyi eszközök létét a vállalkozásban.

20. táblázat: Tárgyi eszközökre vonatkozó számviteli politikai döntések - könyvelök

\begin{tabular}{|c|c|c|c|c|c|c|}
\hline \multirow{2}{*}{$\begin{array}{l}\text { Beszámoló } \\
\text { típusa }\end{array}$} & \multicolumn{6}{|c|}{ Számítási módszer } \\
\hline & lineáris & \multicolumn{2}{|c|}{ lineáristól eltérő } & \multicolumn{2}{|c|}{ eltérők aránya } & nem releváns \\
\hline EÉ & 405 & \multicolumn{2}{|r|}{4} & \multicolumn{2}{|r|}{$1,0 \%$} & 63 \\
\hline ÉB & 20 & \multicolumn{2}{|r|}{0} & \multicolumn{2}{|r|}{$0,0 \%$} & 1 \\
\hline Összzesen & 425 & \multicolumn{2}{|r|}{4} & \multicolumn{2}{|r|}{$0,9 \%$} & 64 \\
\hline \multirow{2}{*}{$\begin{array}{c}\text { Beszámoló } \\
\text { típusa }\end{array}$} & \multicolumn{6}{|c|}{ Leírási kulcs } \\
\hline & TAO szerinti & \multicolumn{2}{|c|}{ TAO-tól eltérő } & \multicolumn{2}{|c|}{ eltérök aránya } & nem releváns \\
\hline EÉ & 386 & \multicolumn{2}{|r|}{23} & \multicolumn{2}{|r|}{$5,6 \%$} & 63 \\
\hline ÉB & 11 & \multicolumn{2}{|r|}{9} & \multicolumn{2}{|r|}{$45,0 \%$} & 1 \\
\hline Összesen & 397 & \multicolumn{2}{|r|}{32} & \multicolumn{2}{|r|}{$7,5 \%$} & 64 \\
\hline \multirow{2}{*}{$\begin{array}{c}\text { Beszámoló } \\
\text { típusa }\end{array}$} & \multicolumn{6}{|c|}{ Maradványérték } \\
\hline & nincs & van & & eltér & k aránya & nem releváns \\
\hline EÉ & 236 & & 173 & & $42,3 \%$ & 63 \\
\hline ÉB & ( & & 20 & & $100,0 \%$ & 1 \\
\hline Összesen & 231 & & 193 & & $45,0 \%$ & 64 \\
\hline & & & s érté & ü leír: & & \\
\hline típusa & $\begin{array}{c}\text { alkalmazza } \\
(100 \mathrm{eFt})\end{array}$ & $\begin{array}{l}\text { alkalmazza } \\
\text { (más összeg) }\end{array}$ & $\begin{array}{r}n \\
\text { alka }\end{array}$ & mazza & $\begin{array}{l}\text { eltérök } \\
\text { aránya }\end{array}$ & $\begin{array}{l}\text { nem } \\
\text { releváns }\end{array}$ \\
\hline EÉ & 462 & 0 & & 0 & $0,0 \%$ & 10 \\
\hline ÉB & 21 & 0 & & 0 & $0,0 \%$ & 0 \\
\hline Összesen & 483 & $\mathbf{0}$ & & $\mathbf{0}$ & $0,0 \%$ & 10 \\
\hline
\end{tabular}

Forrás: Könyvelőirodák adatai alapján saját szerkesztés

Itt is megfigyelhető a lineáris leírás elsöprő fölénye és szinte kizárólagos használata. Eltérés esetén elmondták, hogy azon cégek is alapesetben lineáris leírás alkalmaznak, csak egy-egy speciális eszköz esetén jelent meg más módszer (kutatóeszközök, amelyekre gyorsított leírást alkalmaznak, illetve nagy értékü 
mezőgazdasági jármü, ahol a tulajdonos kérésére teljesítményarányos értékcsökkenési leírást alkalmaznak). Hasonló okokra vezethetőek vissza az eltérő kulcsok alkalmazása is, többnyire pályázatból finanszírozott eszközök esetében a pályázathoz kötődő feltételrendszer a magyarázata az eltérésnek és nem a hasznos élettartamra vonatkozó eltérő becslés. Maradványérték alkalmazására jellemzően gépjármüvek esetén kerül sor, a többi vagyoni elemnél nem jellemző. Így azon cégek, amelyek nem rendelkeztek jármüvel ott nem került sor maradványérték meghatározásra. Kis értékü tárgyi eszköznél nem volt eltérés egyik típusnál sem, mindenki élt az alkalmazás lehetőségével.

A vizsgálat rámutatott, hogy az elérések egy része (leírási mód) inkább eset specifikus és nem a vállalkozás nagyságának függvénye, más része (pl. maradványérték) a vállalatmérettel közvetetten kapcsolatba hozható, hiszen a tárgyi eszközök állománya és összetétele (nagyobb eséllyel van autó a vállalkozás tulajdonában a nagyobb cégek esetén) eltérést mutat.

\section{Választott devizaárfolyamra vonatkozó döntés}

A devizás tételek forintra való átszámításához használt árfolyam tekintetében a Szt. 60. § (4)-(6) az irányadó, amely szerint a gazdálkodó dönthet a - választott hitelintézet által meghirdetett devizavételi és devizaeladási árfolyam átlagának vagy a Magyar Nemzeti Bank (illetve az Európai Központi Bank) által közzétett hivatalos devizaárfolyam alkalmazásáról. Indokolt esetben (ha az átszámítás miatti eltérésnek az eszközökre-forrásokra, illetve az eredményre gyakorolt hatása jelentős és emiatt a megbízható és valós összkép követelménye nem teljesülne) választhat csak devizavételi vagy csak devizaeladási árfolyamot.

A beszámolók kiegészítő mellékletében 37 esetben találtam említést a választott devizaárfolyamra vonatkozóan, az éves beszámolót készítőknél nagyobb volt az említés aránya, mint az egyszerüsített éves beszámolót készítőknél. Az MNB árfolyam alkalmazása volt a jellemző, de mindkét kategóriában találtam hitelintézeti átlagot használó vállalkozást, sőt az éves beszámolót készítők között volt egy pénzintézeti vételi árfolyamot használó (nagy export tevékenységgel rendelkező) vállalkozást is. 
21. táblázat: Választott devizára vonatkozó számviteli politikai döntések - beszámolók

\begin{tabular}{|l|r|r|r|r|r|}
\hline \multirow{2}{*}{$\begin{array}{c}\text { Beszámoló } \\
\text { típusa }\end{array}$} & \multicolumn{5}{|c|}{ Választott árfolyam } \\
\cline { 2 - 6 } & MNB & $\begin{array}{c}\text { hitelintézeti } \\
\text { átlag }\end{array}$ & egyéb & $\begin{array}{c}\text { eltérök } \\
\text { aránya }\end{array}$ & $\begin{array}{c}\text { nincs } \\
\text { említés }\end{array}$ \\
\hline EÉ & 17 & 2 & 0 & $\mathbf{1 0 , 5} \%$ & 81 \\
\hline ÉB & 14 & 3 & 1 & $\mathbf{2 2 , 2} \%$ & 12 \\
\hline \hline Összesen & 31 & 5 & 1 & $\mathbf{1 6 , 2} \%$ & 93 \\
\hline
\end{tabular}

Forrás: Számviteli beszámolók adatai alapján saját szerkesztés

A könyvelőirodák adatai rámutattak, hogy nagyon sok vállalkozás nem rendelkezik devizás tétellel (a $70 \%$ körüli adat nagyságrendje megegyezik a beszámolók esetében árfolyamválasztást nem említők arányával). A kisebb vállalkozások körében lévő MNB árfolyam dominanciájának magyarázata magukban a könyvelökben keresendőek.

22. táblázat: Választott devizára vonatkozó számviteli politikai döntések - könyvelők

\begin{tabular}{|l|r|r|r|r|r|}
\hline \multirow{2}{*}{$\begin{array}{c}\text { Beszámoló } \\
\text { típusa }\end{array}$} & \multicolumn{5}{|c|}{ Választott árfolyam } \\
\cline { 2 - 6 } & MNB & $\begin{array}{c}\text { hitelintézeti } \\
\text { átlag }\end{array}$ & egyéb & $\begin{array}{c}\text { eltérök } \\
\text { aránya }\end{array}$ & $\begin{array}{c}\text { nem } \\
\text { releváns }\end{array}$ \\
\hline EÉ & 149 & 4 & 0 & $\mathbf{2 , 6} \%$ & 319 \\
\hline ÉB & 15 & 4 & 0 & $\mathbf{2 1 , 1} \%$ & 2 \\
\hline \hline Összesen & $\mathbf{1 6 4}$ & $\mathbf{8}$ & $\mathbf{0}$ & $\mathbf{4 , 7} \%$ & $\mathbf{3 2 1}$ \\
\hline
\end{tabular}

Forrás: Könyvelőirodák adatai alapján saját szerkesztés

Jellemzően saját munkájuk megkönnyítése érdekében használják az MNB árfolyamot, így föleg a sok ügyféllel rendelkező irodák esetén nem kell külön keresgetni a választott pénzintézeti (ha eltérő bankoknál vezetik a számlát) átlagárfolyamot. Másik meghatározó szempont az általános forgalmi adó, amelynél adóhatósági bejelentés esetén MNB árfolyam használható, egyébként deviza eladási, s ez utóbbi esetben eltérő árfolyamon van az alaptétel és az áfa, amik külön figyelmet igényel (tehát plusz munka). 
Készletgazdálkodásra vonatkozó döntés

Készletekkel kapcsolatosan két döntési esetet vizsgálhatunk, egyik a készletnyilvántartásra vonatkozik (vezet folyamatos készletnyilvántartást vagy nem vezet), a másik az készlet értékeléssel kapcsolatos döntés (átlag, FIFO).

A beszámolók elemzése során az éves beszámolót készítőknél itt tapasztaltam először, hogy 50 \%-ot meghaladta azok száma, akik nem tettek említést a készletekre vonatkozóan. A mérlegben ellenőriztem az adatokat és jellemzően nem rendelkeztek készlettel azon vállalkozások, ahol nem volt említés (ez az egyszerüsített éves beszámolót készítők esetében is igaz volt). Itt már komolyabb különbség volt megfigyelhető a két kategóriába tartozó cégek között, az egyszerűsített éves beszámolót készítők esetében a nem vezet év közben folyamatos készletnyilvántartást, míg az éves beszámolót készítőknél a folyamatos készletnyilvántartás volt a jellemző.

Értékelés esetén, ha valaki már vezetett év közben folyamatos készletnyilvántartást, akkor jellemzően átlagárat alkalmazott. A FIFO kategóriába beleértetem a készletnyilvántartást nem vezetőket is, ők jellemzően az utolsó beszerzési áron jelenítik meg a zárókészleteik értékét, amely a FIFO logikájának felel meg.

23. táblázat: Készletekre vonatkozó számviteli politikai döntések - beszámolók

\begin{tabular}{|c|c|c|c|c|c|c|}
\hline \multirow{2}{*}{$\begin{array}{c}\text { Beszámoló } \\
\text { típusa }\end{array}$} & \multicolumn{6}{|c|}{ Nyilvántartás } \\
\hline & nem vezet & \multicolumn{2}{|c|}{ vezet } & \multicolumn{2}{|c|}{ eltérők aránya } & nincs említés \\
\hline EÉ & 19 & \multicolumn{2}{|r|}{2} & \multicolumn{2}{|r|}{$9,5 \%$} & 79 \\
\hline ÉB & 3 & \multicolumn{2}{|r|}{8} & \multicolumn{2}{|r|}{$72,7 \%$} & 19 \\
\hline Összesen & 22 & \multicolumn{2}{|c|}{10} & \multicolumn{2}{|r|}{$31,3 \%$} & 98 \\
\hline \multirow{2}{*}{$\begin{array}{c}\text { Beszámoló } \\
\text { típusa }\end{array}$} & \multicolumn{6}{|c|}{ Értékelés } \\
\hline & FIFO & átlag & & & $\begin{array}{l}\text { eltérök } \\
\text { aránya }\end{array}$ & $\begin{array}{c}\text { nincs } \\
\text { említés }\end{array}$ \\
\hline EÉ & 21 & 2 & & 0 & $8,7 \%$ & 77 \\
\hline ÉB & 10 & 7 & & 0 & $41,2 \%$ & 13 \\
\hline Összesen & 31 & 9 & & 0 & $22,5 \%$ & 90 \\
\hline
\end{tabular}

Forrás: Számviteli beszámolók adatai alapján saját szerkesztés 
A vizsgált könyvelöirodák esetében a készlettel rendelkezők alig több, mint $10 \%$-a vezetett folyamatos készletnyilvántartást. Ök jellemzően olyan vállalkozások, ahol valamilyen más jogszabály elöírja a készletek folyamatos nyilvántartását (színesfém-kereskedő, dohánykereskedő), a kereskedő cégek többi része jellemzően rendelkezik valamilyen szintü készletnyilvántartással, de az nincs összekötve a számviteli rendszerrel, vagyis ott nem kerül folyamatosan rögzítésre. Év végi leltár alapján történik a zárókészlet meghatározása és ebből visszavezetve az állományváltozások elszámolása.

Az éves beszámolót készítők esetében itt különbség volt megfigyelhető (a beszámolók adatbázisával összehasonlítva) a készletértékelés kapcsán, jelentősen kisebb volt az átlagos értékelést választók aránya, tehát kisebb fokú volt az eltérők aránya.

24. táblázat: Készletekre vonatkozó számviteli politikai döntések - könyvelők

\begin{tabular}{|c|c|c|c|c|c|c|}
\hline \multirow{2}{*}{$\begin{array}{c}\text { Beszámoló } \\
\text { típusa }\end{array}$} & \multicolumn{6}{|c|}{ Nyilvántartás } \\
\hline & nem vezet & \multicolumn{2}{|c|}{ vezet } & \multicolumn{2}{|c|}{ eltérök aránya } & nem releváns \\
\hline EÉ & 144 & \multicolumn{2}{|c|}{18} & \multicolumn{2}{|r|}{$11,1 \%$} & 310 \\
\hline ÉB & 11 & \multicolumn{2}{|r|}{7} & \multicolumn{2}{|r|}{$38,9 \%$} & 3 \\
\hline Összesen & 155 & \multicolumn{2}{|c|}{25} & \multicolumn{2}{|r|}{$13,9 \%$} & 313 \\
\hline \multirow{2}{*}{$\begin{array}{l}\text { Beszámoló } \\
\text { típusa }\end{array}$} & \multicolumn{6}{|c|}{ Értékelés } \\
\hline & FIFO & átlag & & & $\begin{array}{l}\text { eltérók } \\
\text { aránya }\end{array}$ & $\begin{array}{l}\text { nem } \\
\text { releváns }\end{array}$ \\
\hline EÉ & 159 & 3 & & 0 & $1,9 \%$ & 310 \\
\hline ÉB & 17 & 1 & & 0 & $5,6 \%$ & 3 \\
\hline Összesen & 176 & 4 & & 0 & $2,2 \%$ & 313 \\
\hline
\end{tabular}

Forrás: Könyvelőirodák adatai alapján saját szerkesztés

\section{Költségelszámolás és eredménykimutatás}

Költségelszámolás tekintetében lehetőség van csak költségnem (csak 5. számlaosztály), illetve kombinált költségelszámolás (5. és 6-7. számlaosztály) alkalmazására. Eredménykimutatás esetén két típus közül választhatnak a cégek összköltséges és forgalmi költség eljárásra épülő eredménykimutatást készíthetnek. 
A kiegészítő mellékletekben nem volt mindenhol utalás a költségelszámolás módjára, ahol volt az egyszerüsített éves beszámolót készítők esetében kizárólag költségnem elszámolást, míg az éves beszámolót készítők esetében találkozhattunk kombinált költségelszámolást készítő vállalkozásokkal (két mezőgazdasági, egy kohászati és egy müszaki cikk gyártó).

Az eredménykimutatás fajtája egyértelmüen megállapítható volt minden esetben, hiszen része a számviteli beszámolónak. A kisebb vállalkozások esetén kivétel nélkül mindenki összköltséges eredménykimutatást készített, míg a nagyobb vállalkozások esetén a cégek egyötöde választott eltérően, forgalmi költség eljárásra épülő eredménykimutatást vagy mindkét típust elkészítette és közzétette.

25. táblázat: Költség elszámolás és eredménykimutatás - beszámolók

\begin{tabular}{|c|c|c|c|c|c|c|c|}
\hline \multirow{2}{*}{$\begin{array}{c}\text { Beszámoló } \\
\text { típusa }\end{array}$} & \multicolumn{7}{|c|}{ Költség elszámolás } \\
\hline & \multicolumn{2}{|c|}{ csak költségnem } & \multicolumn{2}{|c|}{ kombinált } & \multicolumn{2}{|c|}{ eltérők aránya } & nincs említés \\
\hline EÉ & \multicolumn{2}{|c|}{21} & \multicolumn{2}{|r|}{0} & \multicolumn{2}{|r|}{$0,0 \%$} & 79 \\
\hline ÉB & \multicolumn{2}{|c|}{7} & \multicolumn{2}{|r|}{4} & \multicolumn{2}{|r|}{$36,4 \%$} & 19 \\
\hline Összesen & \multicolumn{2}{|c|}{28} & \multicolumn{2}{|r|}{4} & \multicolumn{2}{|r|}{$12,5 \%$} & 98 \\
\hline \multirow{2}{*}{$\begin{array}{c}\text { Beszámoló } \\
\text { típusa }\end{array}$} & \multicolumn{7}{|c|}{ Eredménykimutatás fajtája } \\
\hline & Összköltséges & \multicolumn{2}{|c|}{$\begin{array}{l}\text { Forgalmi } \\
\text { költséges }\end{array}$} & \multicolumn{2}{|c|}{ mindkettő } & $\begin{array}{l}\text { eltérók } \\
\text { aránya }\end{array}$ & $\begin{array}{l}\text { nincs } \\
\text { említés }\end{array}$ \\
\hline EÉ & 100 & & 0 & & 0 & $0,0 \%$ & 0 \\
\hline ÉB & 24 & & 4 & & 2 & $20,0 \%$ & 0 \\
\hline Összesen & 124 & & 4 & & 2 & $4,6 \%$ & 0 \\
\hline
\end{tabular}

Forrás: Számviteli beszámolók adatai alapján saját szerkesztés

A mélyinterjús kutatás esetén a kisebb vállalkozások esetén nem mutatkozott eltérés, mindenki költségnem elszámolást alkalmazott és összköltséges eredménykimutatást készített. A nagyobb vállalkozások esetén bár kettő alkalmazott kombinált költségelszámolást (bányászat és nyomdaipar), de mindenki összköltséges eredménykimutatást készített. A könyvelők elmondták, hogy az általuk könyvelt cégek egy részénél van egyéb költséggyüjtés is (jellemzően munkaszámos) csak nem rögzítik a 6.-7. számlaosztályban. 
26. táblázat: Költség elszámolás és eredménykimutatás - könyvelök

\begin{tabular}{|c|c|c|c|c|c|c|c|}
\hline \multirow{2}{*}{$\begin{array}{c}\text { Beszámoló } \\
\text { típusa }\end{array}$} & \multicolumn{7}{|c|}{ Költség elszámolás } \\
\hline & \multicolumn{2}{|c|}{ csak költségnem } & \multicolumn{2}{|c|}{ kombinált } & \multicolumn{2}{|c|}{ eltérők aránya } & nem releváns \\
\hline EÉ & \multicolumn{2}{|c|}{472} & \multicolumn{2}{|r|}{0} & \multicolumn{2}{|r|}{$0,0 \%$} & 0 \\
\hline ÉB & \multicolumn{2}{|c|}{19} & \multicolumn{2}{|r|}{2} & \multicolumn{2}{|r|}{$9,5 \%$} & \multirow[b]{2}{*}{0} \\
\hline Összesen & \multicolumn{2}{|c|}{491} & \multicolumn{2}{|r|}{2} & \multicolumn{2}{|r|}{$0,4 \%$} & \\
\hline \multirow{2}{*}{$\begin{array}{c}\text { Beszámoló } \\
\text { típusa }\end{array}$} & \multicolumn{7}{|c|}{ Eredménykimutatás fajtája } \\
\hline & Összköltséges & \multicolumn{2}{|c|}{$\begin{array}{l}\text { Forgalmi } \\
\text { költséges }\end{array}$} & \multicolumn{2}{|c|}{ mindkettő } & $\begin{array}{l}\text { eltérők } \\
\text { aránya }\end{array}$ & $\begin{array}{c}\text { nem } \\
\text { releváns }\end{array}$ \\
\hline EÉ & 472 & & 0 & & 0 & $0,0 \%$ & 0 \\
\hline ÉB & 21 & & 0 & & 0 & $0,0 \%$ & 0 \\
\hline Összesen & 493 & & 0 & & 0 & $0,0 \%$ & 0 \\
\hline
\end{tabular}

Forrás: Könyvelöirodák adatai alapján saját szerkesztés

A két vizsgálat közötti különbséget az okozhatja, hogy a nagyvállalati mintába belekerülhetek és bele is kerültek olyan vállalkozások is, amelyeknek nagyobb méretüknél, komplexebb tevékenységüknél fogva összetettebb számviteli rendszerrel rendelkeznek és saját számviteli részlegük van (nem könyvelő irodával dolgoztatnak).

A H2 hipotézis vizsgálatához felhasznált számviteli politikai döntések vizsgálata során sokkal alacsonyabb volt az említések száma a kiegészítő mellékletekben, illetve sokkal kisebb körben volt releváns a kérdés a könyvelöirodás vállalkozásoknál.

Alapítás átszervezés és Kísérleti fejlesztés költségeinek elszámolása

Az vállalkozás megkezdésével, indításával, illetve jelentős bővítésével, átalakításával, átszervezésével kapcsolatos tételek aktiválásáról vagy azonnal az eredmény terhére történő elszámolásáról a vállalkozó dönt. (Szt. 25.§ (3))

A kísérleti-kutatási tevékenységgel kapcsolatosan a jövőben (várhatóan) hasznosítható (az árbevételben megtérülő) tételek, amennyiben más eszközök értékében nem aktiválhatóak a vállalkozás döntésének függvényében aktiválhatóak különálló 
immateriális eszközként vagy a felmerülés pillanatában az eredmény terhére elszámolhatóak. Alapkutatás és alkalmazott kutatás nem aktiválható, kísérleti fejlesztés aktiválható. (Szt. 25.§ (2), (4) és (5))

A számviteli beszámolók elemzése esetén csak éves beszámolót készítő vállalkozások esetén találtam az aktiválás mellett döntő vállalkozást. Az egyszerüsített éves beszámolót készítők esetén egyetlen esetben volt említés, hogy az aktiválásról mindkét kategória tekintetében eseti döntést hoznak.

A könyvelőirodás cégek esetén az alapítást két cég esetében aktiválták (cégvezető kérése), a többiek esetében költségként számolták el. Igaz ez azon cégekre is, amelyek a nem releváns kategóriában vannak, mert a visszakérdezés után kiderült, hogy a kezdeti alapítással kapcsolatos kiadások (ügyvédi költség, cégbejegyzési illeték) azonnal eredmény terhére lettek elszámolva, ezt követően azonban semmi ehhez a kategóriához kapcsolódó tétel nem merült fel, ezért sorolták őket a nem releváns körbe.

27. táblázat: Alapítás-átszervezés, Kísérleti fejlesztés - beszámolók

\begin{tabular}{|c|c|c|c|c|c|}
\hline \multirow{2}{*}{$\begin{array}{c}\text { Beszámoló } \\
\text { típusa }\end{array}$} & \multicolumn{5}{|c|}{ Alapítás átszervezés költségének elszámolása } \\
\hline & költségként & aktiválja & $\begin{array}{c}\text { eseti } \\
\text { döntés }\end{array}$ & $\begin{array}{l}\text { eltérök } \\
\text { aránya }\end{array}$ & $\begin{array}{c}\text { nincs } \\
\text { említés }\end{array}$ \\
\hline EÉ & 2 & 0 & 1 & $33,3 \%$ & 97 \\
\hline ÉB & 3 & 8 & 0 & $72,7 \%$ & 19 \\
\hline Összesen & 5 & 8 & 1 & $64,3 \%$ & 116 \\
\hline \multirow{2}{*}{$\begin{array}{c}\text { Beszámoló } \\
\text { típusa }\end{array}$} & \multicolumn{5}{|c|}{ Kísérleti fejlesztés költségének elszámolása } \\
\hline & költségként & aktiválja & $\begin{array}{c}\text { eseti } \\
\text { döntés }\end{array}$ & $\begin{array}{l}\text { eltérők } \\
\text { aránya }\end{array}$ & $\begin{array}{c}\text { nincs } \\
\text { említés }\end{array}$ \\
\hline EÉ & 29 & 0 & 1 & $3,3 \%$ & 70 \\
\hline ÉB & 7 & 5 & 0 & $41,7 \%$ & 18 \\
\hline Összesen & 36 & 5 & 1 & $14,3 \%$ & 88 \\
\hline
\end{tabular}

Forrás: Számviteli beszámolók adatai alapján saját szerkesztés

A kísérleti fejlesztés jelenléte nem általános a vállalkozások életében, erősen tevékenység függő, ennek visszaigazolása az a 9 vállalkozás, amelynél megjelent a tétel a mérlegükben (szoftverfejlesztő, mérnöki kutató, egészségügyi kutató cég). 
28. táblázat: Alapítás-átszervezés, Kísérleti fejlesztés - könyvelők

\begin{tabular}{|c|c|c|c|c|}
\hline \multirow{2}{*}{$\begin{array}{l}\text { Beszámoló } \\
\text { típusa }\end{array}$} & \multicolumn{4}{|c|}{ Alapítás átszervezés költségének elszámolása } \\
\hline & költségként & aktiválja & $\begin{array}{l}\text { eltérök } \\
\text { aránya }\end{array}$ & nem releváns \\
\hline EÉ & 11 & 3 & $21,4 \%$ & 457 \\
\hline ÉB & 6 & 0 & $0,0 \%$ & 15 \\
\hline Összesen & 17 & 3 & $15,0 \%$ & 472 \\
\hline \multirow{2}{*}{$\begin{array}{c}\text { Beszámoló } \\
\text { típusa }\end{array}$} & \multicolumn{4}{|c|}{ Kísérleti fejlesztés költségének elszámolása } \\
\hline & költségként & aktiválja & $\begin{array}{l}\text { eltérők } \\
\text { aránya }\end{array}$ & nem releváns \\
\hline EÉ & 1 & 9 & $90,0 \%$ & 463 \\
\hline ÉB & 0 & 0 & $0,0 \%$ & 21 \\
\hline Összesen & 1 & 9 & $90,0 \%$ & 484 \\
\hline
\end{tabular}

Forrás: Könyvelöirodák adatai alapján saját szerkesztés

Az alapítás-átszervezés és a kísérleti fejlesztés esetén is azt mutatta a vizsgálat, hogy kizárólag a nagyobb vállalkozások esetében van szó egyáltalán a mérlegben való megjelenítésről (egyetlen kisebb vállalkozásnál volt megjelenítve, hogy eseti döntés függvénye az elszámolás módja).

\section{Értékhelyesbités}

A befektetett eszközök bizonyos körénél kimutatható a piaci érték és a könyv szerinti érték közötti pozitív különbözet, ha az tartós és jelentős. Saját tőkével szemben (értékelési tartalék) kerül elszámolásra, tehát eredményhatása nincs. Alkalmazása nem kötelező.

Az értékhelyesbítés alkalmazása esetén bár a kiegészítő mellékletben sok esetben nem találtam információt, a mérlegből valamelyest lehet információt szerezni arra a tényre vonatkozóan, hogy aktuálisan van-e értékhelyesbítése a vállalkozásnak. Azon vállalkozások esetében, ahol nem volt említés az alkalmazásról, itt a mérleg megfelelő sorai sem rendelkeztek értékkel. 
Az értékhelyesbítés magyarországi alkalmazására vonatkozó kutatás rámutatott, hogy jellemzően azok a nagyobb vállalkozások élnek az értékhelyesbítés lehetőségével, akik jelentős piaci értékü ingatlannal rendelkeznek (Kovács [2013]).

Ezt igazolta vissza mindkét vizsgálat. Az alkalmazás okaként saját tőke problémát jelöltek meg, illetve tulajdonosi igény volt az értékhelyesbítés megjelenítésére.

29. táblázat: Értékhelyesbítés - beszámolók

\begin{tabular}{|l|r|r|r|r|}
\hline \multirow{2}{*}{$\begin{array}{c}\text { Beszámoló } \\
\text { típusa }\end{array}$} & \multicolumn{4}{|c|}{ Értékhelyesbítés } \\
\cline { 2 - 5 } & nem alkalmazza & alkalmazza & eltérök aránya & nincs említés \\
\hline EÉ & 7 & 0 & $\mathbf{0 , 0} \%$ & 93 \\
\hline ÉB & 9 & 4 & $\mathbf{3 0 , 8 \%}$ & 17 \\
\hline \hline Összesen & 16 & 4 & $\mathbf{2 0 , 0} \%$ & 110 \\
\hline
\end{tabular}

Forrás: Számviteli beszámolók adatai alapján saját szerkesztés

30. táblázat: Értékhelyesbítés - könyvelők

\begin{tabular}{|l|r|r|r|r|}
\hline \multirow{2}{*}{$\begin{array}{c}\text { Beszámoló } \\
\text { típusa }\end{array}$} & \multicolumn{4}{|c|}{ Értékhelyesbítés } \\
\cline { 2 - 5 } & nem alkalmazza & alkalmazza & eltérök aránya & nem releváns \\
\hline EÉ & 471 & 1 & $\mathbf{0 , 2} \%$ & 0 \\
\hline ÉB & 18 & 3 & $\mathbf{1 4 , 3 \%}$ & 0 \\
\hline \hline Összesen & 489 & 4 & $\mathbf{0 , 8} \%$ & 0 \\
\hline
\end{tabular}

Forrás: Könyvelőirodák adatai alapján saját szerkesztés

\section{Céltartalék képzés jövőbeli költségekre}

A számviteli törvény lehetőséget nyújt olyan jövőben várható, jelentős és időszakonként ismétlődő (fenntartási, átszervezési, környezetvédelemmel kapcsolatos) költségek esetén a céltartalék képzésre, amelyek feltételezhetően vagy bizonyosan felmerülnek, de összegük vagy felmerülésük időpontja a mérlegkészítéskor még bizonytalan. (Szt. 41. (2)) 
A beszámolók esetén csak nagyobb vállalatokhoz kapcsolódóan találtam esetet az alkalmazásra, a könyvelő irodáknál az alkalmazó kisebb vállalkozások mind egyetlen iroda ügyfelei, akiknél a könyvelő tanácsára jelent meg a céltartaléknak ez a fajtája.

31. táblázat: Céltartalék jövőbeli költségekre - beszámolók

\begin{tabular}{|l|r|r|r|r|}
\hline \multirow{2}{*}{$\begin{array}{c}\text { Beszámoló } \\
\text { típusa }\end{array}$} & \multicolumn{4}{|c|}{ Céltartalék képzése jövőbeli költségekre } \\
\cline { 2 - 5 } & nem alkalmazza & alkalmazza & eltérók aránya & nincs említés \\
\hline EÉ & 21 & 0 & $\mathbf{0 , 0} \%$ & 79 \\
\hline ÉB & 2 & 4 & $\mathbf{6 6 , 7} \%$ & 24 \\
\hline \hline Összesen & 23 & 4 & $\mathbf{1 4 , 8 \%}$ & 103 \\
\hline
\end{tabular}

Forrás: Számviteli beszámolók adatai alapján saját szerkesztés

32. táblázat: Céltartalék jövőbeli költségekre - könyvelők

\begin{tabular}{|l|r|r|r|r|}
\hline \multirow{2}{*}{$\begin{array}{c}\text { Beszámoló } \\
\text { típusa }\end{array}$} & \multicolumn{4}{|c|}{ Céltartalék képzése jövőbeli költségekre } \\
\cline { 2 - 5 } & nem alkalmazza & alkalmazza & eltérök aránya & nem releváns \\
\hline EÉ & 457 & 15 & $\mathbf{3 , 2} \%$ & 0 \\
\hline ÉB & 20 & 1 & $\mathbf{4 , 8} \%$ & 0 \\
\hline \hline Összesen & 477 & 16 & $\mathbf{3 , 2} \%$ & 0 \\
\hline
\end{tabular}

Forrás: Könyvelőirodák adatai alapján saját szerkesztés

Beruházási hitel nem realizált árfolyamveszteségének elhatárolása

A vállalkozások a beruházásokhoz, vagyoni értékű jogokhoz és a forgóeszközökhöz (2013 óta) kapcsolódó devizás hiteltartozás, illetve devizakötvény kibocsátásból származó tartozás év végi értékelésekor keletkező nem realizált árfolyamveszteséget elhatárolhatja (Halaszott ráfordítás)

A beszámolók vizsgálata során egy-egy esetet találtam mindkét vizsgált mintában.

A könyvelő irodás mintában a cégek jellemzően nem rendelkeznek devizahitellel. Két irodánál volt ilyen típusú elhatárolás, az egyiknél 2 nagyobb vállalkozás esetében korábbi (több, mint 5 évvel ezelőtt felvett) hitelhez kapcsolódóan, a másik irodánál egy cégcsoport minden tagjára vonatkozóan (5 éves és 6 egyszerüsített 
éves beszámolót készítő cég) alkalmazzák az elhatárolást. A konszern ingatlankivitelezés és ingatlanhasznosítás területén tevékenykedik.

33. táblázat: Beruházási hitel nem realizált árfolyamvesztesége - beszámolók

\begin{tabular}{|l|r|r|r|r|}
\hline \multirow{2}{*}{$\begin{array}{c}\text { Beszámoló } \\
\text { típusa }\end{array}$} & \multicolumn{4}{|c|}{ Beruházási hitel nem realizált árfolyamveszteségének elhatárolása } \\
\cline { 2 - 5 } & nem alkalmazza & alkalmazza & $\begin{array}{c}\text { eltérók } \\
\text { aránya }\end{array}$ & nincs említés \\
\hline EÉ & 0 & 1 & $\mathbf{1 0 0 , 0 \%}$ & 99 \\
\hline ÉB & 0 & 1 & $\mathbf{1 0 0 , 0 \%}$ & 29 \\
\hline \hline Összesen & 0 & 2 & $\mathbf{1 0 0 , 0 \%}$ & 128 \\
\hline
\end{tabular}

Forrás: Számviteli beszámolók adatai alapján saját szerkesztés

34. táblázat: Beruházási hitel nem realizált árfolyamvesztesége - könyvelők

\begin{tabular}{|l|r|r|r|r|}
\hline \multirow{2}{*}{$\begin{array}{c}\text { Beszámoló } \\
\text { típusa }\end{array}$} & \multicolumn{4}{|c|}{ Beruházási hitel nem realizált árfolyamveszteségének elhatárolása } \\
\cline { 2 - 5 } & nem alkalmazza & alkalmazza & $\begin{array}{c}\text { eltérök } \\
\text { aránya }\end{array}$ & nem releváns \\
\hline EÉ & 0 & 6 & $\mathbf{1 0 0 , 0} \%$ & 466 \\
\hline ÉB & 0 & 7 & $\mathbf{1 0 0 , 0} \%$ & 14 \\
\hline \hline Összesen & 0 & 13 & $\mathbf{1 0 0 , 0} \%$ & 480 \\
\hline
\end{tabular}

Forrás: Könyvelőirodák adatai alapján saját szerkesztés

\section{Valós értékelés}

Valós értéken történő értékelés a pénzügyi instrumentumok esetében alkalmazható. Tőzsdei cégek esetén (konszolidált beszámolójukban) kötelező az alkalmazás, a többi kettős könyvvitelt vezető vállalkozó választhatja a módszert.

Sem a beszámolók, sem a könyvelő irodák esetében nem volt vállalkozás, aki alkalmazta volna a valós értékelést. Összesen 6 alkalommal volt egyáltalán megemlítve, hogy a vállalkozás nem él a valós értékelés alkalmazásával (mindegyik éves beszámolót készítő vállalkozás volt). 
Számviteli politikai döntések többváltozós vizsgálata

A számviteli politikai döntések egyenkénti vizsgálata során arra a megállapításra jutottam, hogy a kisebb vállalkozások esetében kevésbé tapasztalható eltérés az egyszerübb megoldásnak tekintett helyzethez képest, tehát kevésbé választottak más megoldást a vállalkozások, illetve kevésbé éltek olyan számviteli politikai döntések választásával, amelyek használat nem kötelező.

Ezt követően varianciaanalízis segítségével azt vizsgáltam, hogy ez az eltérés szignifikáns-e a minta alapján. A H1 hipotézis kilenc, illetve a H2 hipotézis hat tényezőre vonatkozó átlagos értékének elemzését együttesen mutatom be, mert ugyanazt a módszertant használtam mindkettőnél.

A varianciaelemzés feltétele a függő változó normális eloszlása (ellenőrzés például pontfelhő diagrammal) és a varianciahomogenitás (ellenőrzés Levene-teszttel). „Ugyanakkor a fenti feltételekkel kapcsolatban kihangsúlyozandó, hogy az F próba igen robosztus, ami azt jelenti, hogy egy-egy feltétel (pl. normalitás, varianciahomogenitás) nem teljesülése nem gyakorol lényeges befolyást a próbával elkövethető első- és másodfajú hiba elkövetési valószínüségére, vagyis nem rontja el a következtetések érvényességét, nem növeli jelentősen a hibás döntések számát." (Sajtos - Mitev [2007]: 166-167. oldal)

Ahogy arra már az eloszlásukat leíró részből is következtetni lehetett, a normalitás feltétele mindkét mutató esetében sérül. Ezt mutatja a normalitás teszt (Koglomorov-Smirnov), az eloszlást szemléltető ábrák (hisztogram, doboz ábra, szárlevél ábra) és az összehasonlító ábrák (Normál Q-Q plot és Detrended Normal Q-Q plot) is. Ezek részletes bemutatása a kisebb és nagyobb vállalkozásokra külön-külön, illetve a vállalkozásokat együtt vizsgálva, valamint a varianciaelemzés táblázatai az 5. mellékletben találhatóak.

A varianciaelemzés leíró statisztikájából látható, hogy az átlag körüli 95\%-os konfidencia intervallumok nem fedik át egymást, így megállapítható, hogy ezen a szinten a kisebb vállalkozások kisebb arányban térnek el az egyszerübb megoldások választásától. 
A szóráshomogenitás ellenőrzése a Levene-teszttel történhet, amely mindkét mutató esetében elfogadja a nullhipotézist, azaz a szórások nem egyenlőek a két csoportban, tehát nem teljesül a szóráshomogenitás sem.

Annak ellenére, hogy sem a normalitás, sem a szóráshomogenitás nem teljesül, mégis elvégezhető a varianciaelemzés az említett $\mathrm{F}$ próba robusztusságából adódóan. Az $\mathrm{F}$ próba értékei alapján magas szignifikancia szinten elutasítható a nullhipotézis, vagyis az átlagok egyezősége, így kimutatható, hogy a két csoport átlaga szignifikánsan különbözik egymástól.

35. táblázat: Átlag körüli 95 \%-os konfidencia intervallumok - H1

\begin{tabular}{|l|l|c|}
\hline $\begin{array}{c}\text { Beszámoló } \\
\text { típusa }\end{array}$ & \multicolumn{1}{|c|}{$\begin{array}{c}\text { Cég } \\
\text { formája }\end{array}$} & Átlagos eltérés (Á1) \\
\hline \multirow{3}{*}{ EÉ } & Bt. & $6,06 \%-15,34 \%$ \\
\cline { 2 - 3 } & Kft & $6,95 \%-12,23 \%$ \\
\cline { 2 - 3 } & Bt.+Kft. & $7,63 \%-12,15 \%$ \\
\hline ÉB & Rt. & $17,13 \%-32,49 \%$ \\
\hline \hline Össz. & & $10,68 \%-15,99 \%$ \\
\hline
\end{tabular}

Forrás: $A B: K V$ és $A B: N V$ alapján saját szerkesztés

18. ábra: Varianciaanalízis eredménye - H1 hipotézis

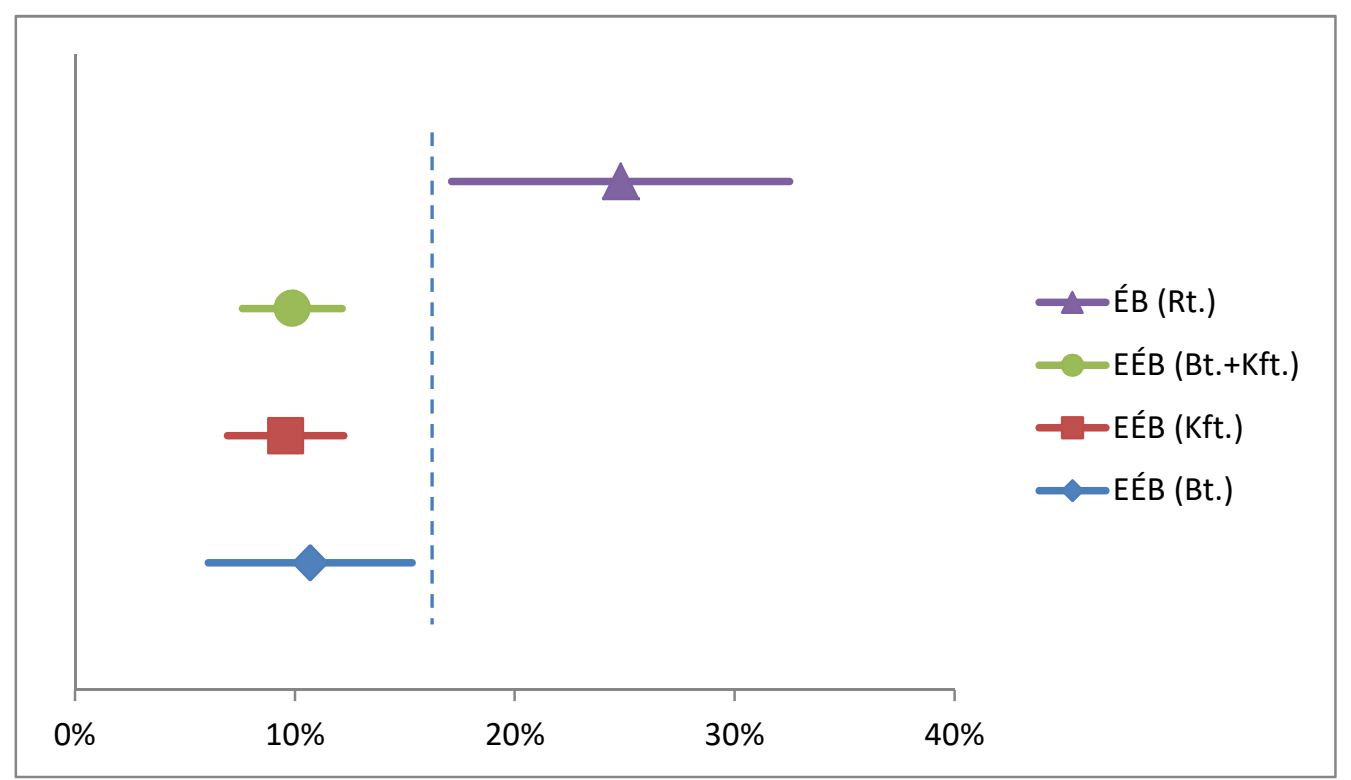

Forrás: $A B: K V$ és $A B: N V$ alapján saját szerkesztés 
36. táblázat: Átlag körüli $95 \%$-os konfidencia intervallumok - H2

\begin{tabular}{|l|l|c|}
\hline $\begin{array}{c}\text { Beszámoló } \\
\text { típusa }\end{array}$ & \multicolumn{1}{|c|}{$\begin{array}{c}\text { Cég } \\
\text { formája }\end{array}$} & Átlagos eltérés (Á1) \\
\hline \multirow{3}{*}{ EÉ } & Bt. & $0,00 \%-0,00 \%$ \\
\cline { 2 - 3 } & Kft & $0,00 \%-1,70 \%$ \\
\cline { 2 - 3 } & Bt.+Kft. & $0,00 \%-1,24 \%$ \\
\hline ÉB & Rt. & $6,34 \%-18,10 \%$ \\
\hline \hline Össz. & & $1,58 \%-3,32 \%$ \\
\hline
\end{tabular}

Forrás: $A B: K V$ és $A B: N V$ alapján saját szerkesztés

19. ábra: Varianciaanalízis eredménye - H2 hipotézis

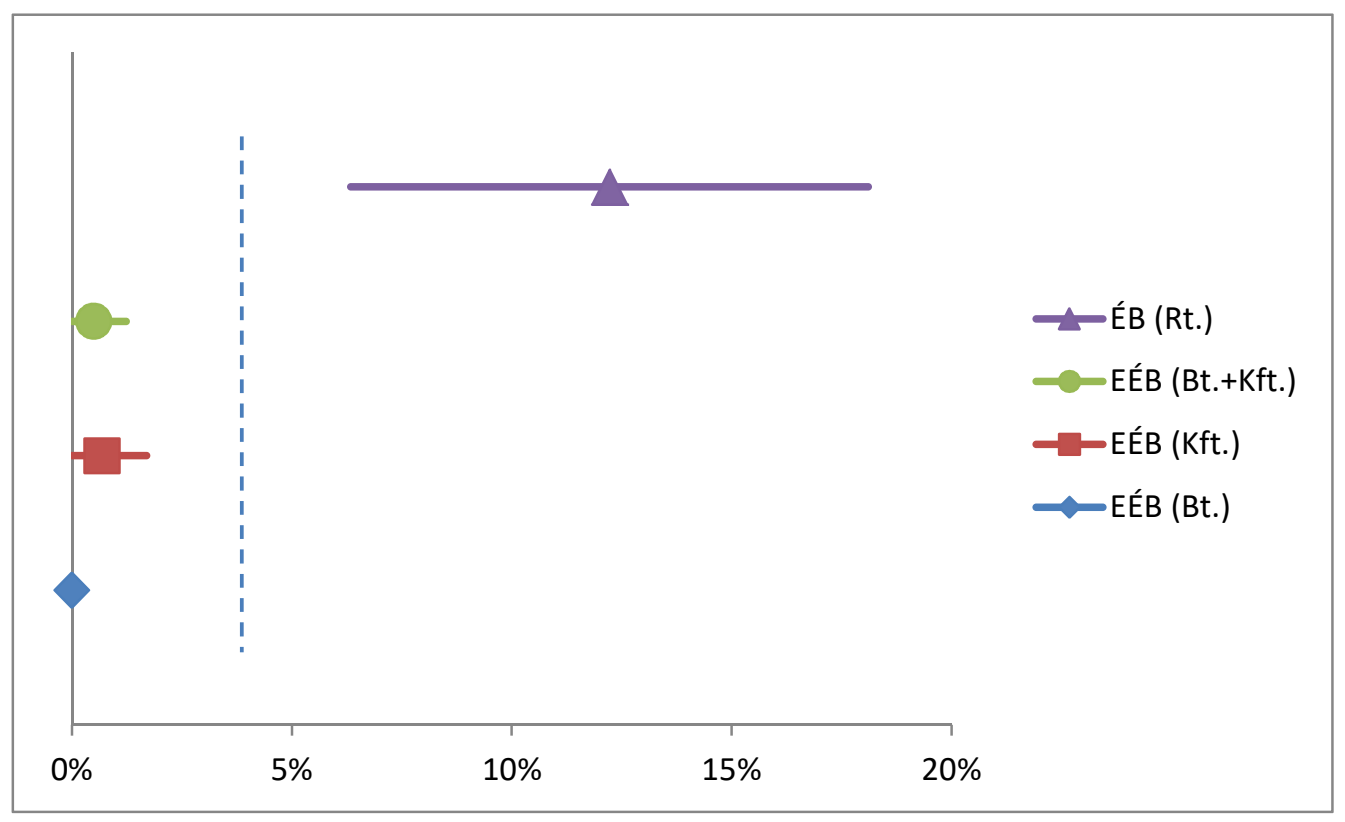

Forrás: $A B: K V$ és $A B: N V$ alapján saját szerkesztés

A vizsgálatokat elvégeztem úgy is, hogy az egyszerüsített éves beszámolós csoportot kettébontva kezeltem, vagyis külön kategóriának tekintve a betéti társaságokat és a korlátolt felelősségü társaságokat. Mindkét hipotézisbeli állítással kapcsolatban arra a megállapításra jutottam, hogy a társasági forma szerint nem tehető további különbség a cégek között. Ezt mutatják az egymást átfedő konfidencia intervallumok a bt-k és a kft-k esetében, valamint a varianciaanalízis vonatkozó statisztikái is: az átlagösszehasonlító ábra (Means Plots), illetve a Scheffé-próba egyidejü páros összehasonlításának szignifikáns értékei (Multiple comparisons) és a homogén 
részhalmazok táblázata (Homogeneous subsec). Ezek részletes számításait az 6. (H1) és 8. (H2) mellékletek tartalmazzák.

\section{Az eredmények alapján a H1 és H2 hipotézist elfogadottnak tekintem.}

A két hipotézis igazolása rávilágít arra, hogy a 2013-ban bevezetett mikrogazdálkodói beszámoló az alkalmazott módszerek és eljárások szempontjából alapvetően nem hozott változást a vállalkozások számviteli rendszerében, igazából a korábban meglévő gyakorlatot képezte le jogszabály formájában. Tehát, amit előírt, azt korábban is jellemzően úgy kezelték a cégek (H1 hipotézisben vizsgált területek), amely tételek alkalmazását tiltja (H2 hipotézisben vizsgált elemek), azok korábban sem jelentek meg a vállalkozások számvitelében.

\section{Időbeli elhatárolások}

Ahol jelentősebb változást jelent a mikrogazdálkodói beszámolóhoz tartozó rendszer az az időbeli elhatárolások területe. Eltérve a számviteli törvénytöl időbeli elhatárolásként csak a kettőnél több évet terhelő költségeket, ráfordításokat, illetve kettőnél több évet illető bevételeket engedi kimutatni. Halasztott bevétel és ráfordítás esetén pedig minimum összeghatárhoz (1 millió forint) köti az elhatárolás lehetőségét.

Ezek a szabályok az időbeli elhatárolások közgazdasági filozófiájának tartalmát részben figyelmen kívül hagyva, az egyszerüsítés jegyében (a két év között átnyúló tételeket nem kell elhatárolni) korlátozott alkalmazást írnak el.

Ezen szabály megítélése vitákat válthat ki, hiszen a megbízható és valós összkép filozófiája az időbeli elhatárolások elvének részbeni használata miatt sérül. A kormányrendelet le is írja, hogy a mikrogazdálkodói beszámolót készítő vállalkozások a jogszabályban rögzítettek betartásával a megbízható és valós összképre vonatkozó követelményrendszertől valójában a „szabályoknak megfelelő” felé mozdulnak el.

Megvizsgáltam az időbeli elhatárolások mérlegfőösszeghez és adózás előtti eredményhez viszonyított arányát, az eredményeket a következő táblázatok szemléltetik. Megállapítható a vállalkozások kb. 70 \%-ánál nem jelenik meg időbeli 
elhatárolás a mérlegben, ahol pedig van ott jellemzően (az alkalmazó cégek több mint felénél) $1 \%$-nál kisebb súlyt képvisel a vállalkozás vagyonához képest.

37. táblázat: Az időbeli elhatárolások relatív értéke (mérlegfőösszeghez viszonyítva)

\begin{tabular}{|c|c|c|c|c|c|c|}
\hline \multirow{3}{*}{ IE / Mfö } & \multicolumn{3}{|c|}{ Aktív időbeli elhatárolás } & \multicolumn{3}{|c|}{ Passzív időbeli elhatárolás } \\
\hline & \multirow{2}{*}{$\begin{array}{l}\text { Váll. } \\
\text { száma } \\
\text { (db) }\end{array}$} & \multicolumn{2}{|c|}{ Váll. aránya } & \multirow{2}{*}{$\begin{array}{c}\text { Váll. } \\
\text { száma } \\
\text { (db) }\end{array}$} & \multicolumn{2}{|c|}{ Váll. aránya } \\
\hline & & teljes & „értékes" & & teljes & ,értékes" \\
\hline $1 \%$ alatt & 66821 & $15,9 \%$ & $56,3 \%$ & 67555 & $16,1 \%$ & $51,6 \%$ \\
\hline $1 \%-5 \%$ & 25671 & $6,1 \%$ & $21,6 \%$ & 31208 & $7,4 \%$ & $23,8 \%$ \\
\hline $5 \%-10 \%$ & 9429 & $2,2 \%$ & $7,9 \%$ & 10568 & $2,5 \%$ & $8,1 \%$ \\
\hline $10 \%$ fölött & 16759 & $4,0 \%$ & $14,1 \%$ & 21530 & $5,1 \%$ & $16,5 \%$ \\
\hline Értelmezhető & 118680 & $28,2 \%$ & $100,0 \%$ & 130861 & $31,1 \%$ & $100,0 \%$ \\
\hline Mfö $=0, \mathrm{NÉ}$ & 24891 & $5,9 \%$ & & 24891 & $5,9 \%$ & \\
\hline van Mfö, de IE nulla & 276952 & $65,9 \%$ & & 264771 & $63,0 \%$ & \\
\hline Összesen & 420523 & $100,0 \%$ & & 420523 & $100,0 \%$ & \\
\hline
\end{tabular}

Forrás: TAO bevallások alapján készített saját számítás

38. táblázat: Az időbeli elhatárolások relatív értéke (adózás előtti eredményhez viszonyítva)

\begin{tabular}{|c|c|c|c|c|c|c|}
\hline \multirow{3}{*}{$\begin{array}{c}\text { IE / } \\
\operatorname{abs}(\mathrm{AEE})\end{array}$} & \multicolumn{3}{|c|}{ Aktív időbeli elhatárolás } & \multicolumn{3}{|c|}{ Passzív időbeli elhatárolás } \\
\hline & \multirow{2}{*}{$\begin{array}{c}\text { Váll. } \\
\text { száma } \\
\text { (db) }\end{array}$} & \multicolumn{2}{|c|}{ Váll. aránya } & \multirow{2}{*}{$\begin{array}{l}\text { Váll. } \\
\text { száma } \\
\text { (db) }\end{array}$} & \multicolumn{2}{|c|}{ Váll. aránya } \\
\hline & & teljes & ,értékes" & & teljes & ,értékes" \\
\hline $1 \%$ alatt & 25606 & $6,1 \%$ & $21,7 \%$ & 22203 & $5,3 \%$ & $17,0 \%$ \\
\hline $1 \%-5 \%$ & 26602 & $6,3 \%$ & $22,5 \%$ & 29741 & $7,1 \%$ & $22,8 \%$ \\
\hline $5 \%-10 \%$ & 11905 & $2,8 \%$ & $10,1 \%$ & 14425 & $3,4 \%$ & $11,1 \%$ \\
\hline $10 \%$ fölött & 54018 & $12,8 \%$ & $45,7 \%$ & 63937 & $15,2 \%$ & $49,1 \%$ \\
\hline Értelmezhető & 118131 & $28,1 \%$ & $100,0 \%$ & 130306 & $31,0 \%$ & $100,0 \%$ \\
\hline $\mathrm{AEE}=0, \mathrm{NE}$ & 33580 & $8,0 \%$ & & 33580 & $8,0 \%$ & \\
\hline nulla & 268812 & $63,9 \%$ & & 256637 & $61,0 \%$ & \\
\hline Összesen & 420523 & $100,0 \%$ & & 420523 & $100,0 \%$ & \\
\hline
\end{tabular}

Forrás: TAO bevallások alapján készített saját számítás

Tovább finomíthatjuk a képet, ha a vállalkozás méretét is figyelembe vesszük. A kisebb vállalkozások esetén az időbeli elhatárolások elvének való megfelelés komoly terhet rótt a vállalkozásra. 
A mikrogazdálkodói beszámoló fogadtatása - az elsö évek tapasztalatainak jegyében.

A könyvelőirodák vezetőivel készült beszélgetések során próbáltam feltérképezni a számvitel egyszerüsítésre vonatkozó törekvésekhez való hozzáállást. Meglehetősen vegyes képet kaptam ezen a téren, amelyet jól tükrözött a mikrogazdálkodói beszámoló bevezetésével kapcsolatos véleményük. Három kategóriát tudtam megkülönböztetni:

- alkalmazók: akik már a bevezetés évében (2013) áttértek ahol lehetett a mikrogazdálkodói beszámolóra (3 cég);

- kivárók: akik még az első évben nem „merték” bevállalni az alkalmazást, de a tapasztalatok függvényében esetlegesen tervezik a későbbiekben az áttérést (4 cég);

- elzárkózók: akik nem tértek át és nem is tervezik a jövőben sem, ragaszkodnak a jelenlegi rendszerükhöz, nem akarnak változást ( 8 cég).

Az első körbe tartozók (alkalmazók) elmondták, hogy nagyon elégedettek az új beszámolási formával. Az a tény, hogy nem kell kiegészítő mellékletet készíteniük, nagyban megkönnyíti a beszámoló-készítés folyamatát, ebben érezik igazából az egyszerüsítés megjelenését. Magában az évközi munkában nem jelent igazi változást, itt is visszaigazolódott a H1-H2 hipotézis, hiszen eddig is ilyen rendszerben könyveltek. Az átállásnak (számlák újra-paraméterezésének) volt némi időigénye, de ez később megtérül(t). Azzal kapcsolatban, hogy nem kell külön szabályzatokat (számviteli politika, készlet-nyilvántartási szabályzat, pénzkezelési szabályzat, számlarend) készíteni, nem éreznek különösebb előnyt, hiszen már müködő cégek esetében ezek korábban elkészültek.

A kivárók az újtól való félelem jegyében nem választották az első évben a mikrogazdálkodói beszámolót. Várják az első év/évek alapján a tapasztalatokat, és utána döntenek.

Az elzárkózóknak elég élesen fogalmazott véleménye és kemény ellenállása volt a mikrogazdálkodói beszámolóval kapcsolatban. Néhányan a jól bejáratott rendszerükhöz való ragaszkodás miatt voltak elutasítóak, (,jó úgy, ahogy van”, ,ezt már megszokták”), volt olyan, aki korábbi rossz tapasztalat miatt elzárkózik minden „csökkentett” módtól, hiszen valahol úgy is bekérik az információt. 
Ezt a véleménykülönbséget tükrözték a mikrogazdálkodói megítélésére vonatkozó kérdésemre kapott válaszok is.

Milyen mértékü egyszerüsítésnek ítéli meg a Mikrogazdálkodói beszámolót egy tízfokozatú skálán? (10 nagymértékü egyszerüsités, 1 semmilyen mértékü egyszerüsités, 0 bonyolitás) Az alkalmazók 8-10, a kivárók 5, az elzárkózók 0-3 értéket adtak (átlag 5,3).

A követő vizsgálat (2017-es évi megkeresés) rámutatott, hogy a cégek hozzáállása nem igazán változott. Egyetlen (korábban kiváró kategóriában lévő) cég esetében következett be változás és 2015-től (2 év tapasztalatát megvárva) elkezdték alkalmazni a mikrogazdálkodói beszámolót. Ugyanakkor elmondták, hogy nem minden cég esetében váltottak, amennyiben banki hitellel rendelkezik egy vállalkozás vagy pályázaton indult/tervez indulni, akkor nem éltek az egyszerüsítés lehetőségével.

A beszélgetések során minden esetben előkerült, hogy nem a számviteli beszámoltatást érzik igazán tehernek, hanem a folyamatosan változó adójogszabályok követését, illetve a többszörös adatszolgáltatást. Ugyanazon adatokat gyakran több hatóság felé kell szolgáltatni, sokszor egymástól eltérő bontásban.

Ennek egyik legjobb példája a társasági adóbevallás, ahol az egyszerüsített éves beszámoló adataihoz képest sokkal mélyebb bontásban bekérik a számviteli beszámolóban közzétételre kerülő vagyoni, pénzügyi és jövedelmi helyzetre vonatkozó adatokat. Tehát hiába próbálkozik a számvitel egyszerüsítéssel, amíg azt más jogszabályok nem követik le, addig nem igazán érezhető a hatás. 


\section{A számvitel és adózás kapcsolatának szorosságára vonatkozó vizsgálatok (H3-H4)}

A kutatás másik iránya a számvitel és az adózás kapcsolatára, annak szorosságára vonatkozik. Feltételezésem szerint a kisebb vállalkozások a számviteli rendszerüket alárendelik az adózásnak, úgy alakítják, hogy minél kisebb legyen az eltérés a számviteli érték és az adózás által elismert érték között, amelynek következtében kevesebb korrekcióra van szükségük az adó megállapításánál.

H3 hipotézis: Magyarországon a kisebb vállalkozásoknál a számviteli (adózás előtti eredmény) és az adózási (adóalap) jövedelemértelmezésben kisebb a relatív eltérés.

A 2015-ös Társasági adóbevallások adatbázisából az adózás előtti eredményt és az adóalapot hasonlítottam össze, a gazdálkodókat méret szerinti kategóriákra bontva. A számvitelben használt Mikrogazdálkodói beszámoló (MG), Egyszerüsített éves beszámoló (EÉ) és Éves beszámoló (ÉB) határértékeit felhasználva képeztem meg a csoportokat.

Első lépésként azt vizsgáltam meg, hogy a két féle jövedelemértelmezés szerint milyen az egyes csoportok megoszlása. Megfigyelhető volt, hogy az adóalap nagyobb számú vállalkozás esetén volt pozitív, mint az adózás előtti eredmény. Több cégnél fordult elő növelő tétel.

39. táblázat: Gazdálkodók megoszlása az Adózás előtti eredmény illetve az Adóalap elöjele szerint

\begin{tabular}{|l|r|r|r|r|r|r|}
\hline \multirow{2}{*}{ Beszámoló } & \multicolumn{2}{|c|}{ Adózás előtti eredmény } & \multicolumn{3}{|c|}{ Adóalap } \\
\cline { 2 - 7 } & pozitív & \multicolumn{1}{c|}{ nulla } & negatív & pozitív & \multicolumn{1}{c|}{ nulla } & negatív \\
\hline MG & $56 \%$ & $9 \%$ & $35 \%$ & $75 \%$ & $15 \%$ & $10 \%$ \\
\hline EÉ & $90 \%$ & $0 \%$ & $10 \%$ & $95 \%$ & $1 \%$ & $4 \%$ \\
\hline ÉB & $89 \%$ & $0 \%$ & $11 \%$ & $91 \%$ & $1 \%$ & $9 \%$ \\
\hline \hline Össz. & $59 \%$ & $8 \%$ & $33 \%$ & $76 \%$ & $14 \%$ & $9 \%$ \\
\hline
\end{tabular}

Forrás: AB: TAO alapján saját szerkesztés 
Méretkategóriánként vizsgálva az adott csoporton belül jellemzőbbek a sokasági áltaghoz képest az EÉ és az ÉB esetén a pozitív, az MG esetén a negatív adózás előtti eredmény. Meg kell említeni, hogy nem csak profitorientált gazdálkodók kötelezettek a társasági adóbevallás benyújtására, ezen egyéb szervezetek - jellemzően MG kategória -, de az adatbázisban nem volt lehetőség a szétválasztásra, ez némi torzítást okozhat.

40. táblázat: Gazdálkodók megoszlása az Adózás előtti eredmény és az Adóalap előjele szerint

\begin{tabular}{|c|c|r|r|r||r|}
\hline AEE & Adóalap & \multicolumn{1}{c|}{ MG } & \multicolumn{1}{c|}{ EÉ } & \multicolumn{1}{c|}{ ÉB } & \multicolumn{1}{c|}{ Össz. } \\
\hline \multirow{3}{*}{ pozitív } & pozitív & $54,95 \%$ & $86,87 \%$ & $85,04 \%$ & $57,28 \%$ \\
\cline { 2 - 6 } & nulla & $0,66 \%$ & $1,00 \%$ & $0,51 \%$ & $0,67 \%$ \\
\cline { 2 - 6 } & negatív & $0,70 \%$ & $1,77 \%$ & $3,61 \%$ & $0,82 \%$ \\
\hline \multirow{3}{*}{ nulla } & pozitív & $0,10 \%$ & $0,05 \%$ & $0,05 \%$ & $0,10 \%$ \\
\cline { 2 - 6 } & nulla & $8,50 \%$ & $0,09 \%$ & $0,09 \%$ & $7,88 \%$ \\
\cline { 2 - 6 } & negatív & $0,01 \%$ & $0,01 \%$ & $0,03 \%$ & $0,01 \%$ \\
\hline \multirow{3}{*}{ negatív } & pozitív & $19,86 \%$ & $7,69 \%$ & $5,48 \%$ & $18,93 \%$ \\
\cline { 2 - 6 } & nulla & $6,20 \%$ & $0,04 \%$ & $0,00 \%$ & $5,74 \%$ \\
\cline { 2 - 6 } & negatív & $9,01 \%$ & $2,48 \%$ & $5,18 \%$ & $8,58 \%$ \\
\hline
\end{tabular}

szürke: összesítetthez képest magasabb arány

Forrás: AB: TAO alapján saját szerkesztés

Ezt követően megvizsgáltam az eltérést az adóalap és az adózás előtti eredmény között, ez eredmények rámutattak, hogy az MG vállalkozások több mint egyharmadánál nincs különbség a két érték között, míg a nagyobb vállalkozások esetében ritka, hogy ne legyen semmilyen irányú eltérés.

41. táblázat: Gazdálkodók megoszlása a jövedelem-eltérés iránya szerint

\begin{tabular}{|l|r|r|r|r|r|r|}
\hline \multirow{2}{*}{ Beszámolón } & \multicolumn{4}{|c|}{ Eltérés (Adóalap - Adózás előtti eredmény) } \\
\cline { 2 - 7 } & \multicolumn{2}{|c|}{$\begin{array}{c}\text { pozitív } \\
\text { (Adóalap > AEE) }\end{array}$} & \multicolumn{2}{c|}{$\begin{array}{c}\text { nincs } \\
\text { (Adóalap = AEE) }\end{array}$} & \multicolumn{2}{c|}{$\begin{array}{c}\text { negatív } \\
\text { (Adóalap < AEE) }\end{array}$} \\
\hline MG & 176641 & $45,4 \%$ & 139790 & $35,9 \%$ & 73034 & $18,8 \%$ \\
\hline EÉ & 11262 & $47,6 \%$ & 1644 & $6,9 \%$ & 10761 & $45,5 \%$ \\
\hline ÉB & 3350 & $45,3 \%$ & 134 & $1,8 \%$ & 3907 & $52,9 \%$ \\
\hline Összesen & 191253 & $45,5 \%$ & 141568 & $33,7 \%$ & 87702 & $20,9 \%$ \\
\hline
\end{tabular}

Forrás: AB: TAO alapján saját szerkesztés 
A jövedelemeltérésnek az adózás elötti eredmény és az adóalap különbségét tekintettem, amelynek abszolút értékét a relatív jövedelem eltérés számításánál az adózás előtti eredményhez viszonyítottam. A számítás során problémát jelentettek azok az esetek, amelyeknél volt a kétféle jövedelemérték között eltérés, azonban az adózás előtti eredmény nulla volt. A számítás eredménye alapján öt csoportot lehetett elkülöníteni

1. nincs eltérés (a mutató értéke 0)

2. a különbség kisebb, mint az adózás előtti eredmény (0-100\%)

3. a különbség egyenlő az adózás előtti eredménnyel (100 \%)

4. a különbség nagyobb, mint az adózás előtti eredmény (nagyobb, mint $100 \%$ )

5. van különbség, viszont az adózás előtti eredmény 0 (technikailag $\infty$ )

Az elemzésnél az 5. csoportot nem lehet értelmezni, míg a 4. csoport esetében sok volt az extrémen kilógó érték, ezt mutatják a mellékletben szereplő szár-levél (Steam and leaves), illetve doboz (Box plot) ábrák. Mivel ezen adatok erőteljesen torzítják a sokasági átlagot, így a teljes elemszámra nem végezhető el az elemzés. Az esetek egy részét ki kell zárni, hogy javuljon a modell használhatósága. A kizárt elemszám növelésével csökken a modellt torzító extrém esetek száma, azonban ez a mintanagyság csökkenésével is együtt jár. A sokaság redukálását két féle változatban vizsgáltam:

- kizártam a 100 \%-nál nagyobb relatív eltérésủ eseteket;

- csak a $100 \%$ alatti eltérésüeket hagytam meg.

Az elemzést varianciaanalízissel hajtottam végre és mindegyik redukált minta esetében sikerült igazolnom, hogy a relatív jövedelmeltérés szignifikáns különbséget mutat mindhárom csoport között (F próba, Scheffe próba), a kisebb vállalkozásoknál kisebb ez az eltérés. Az eredmények mindkét mintanagyság mellett igazolhatóak voltak, az erre vonatkozó számítások részleteit a 9. melléklet tartalmazza. 
Az elemzés során kapott csoport átlagokat szemlélteti a következő ábra.

20. ábra: Relatív jövedelem-eltérés különböző mintanagyságok mellett
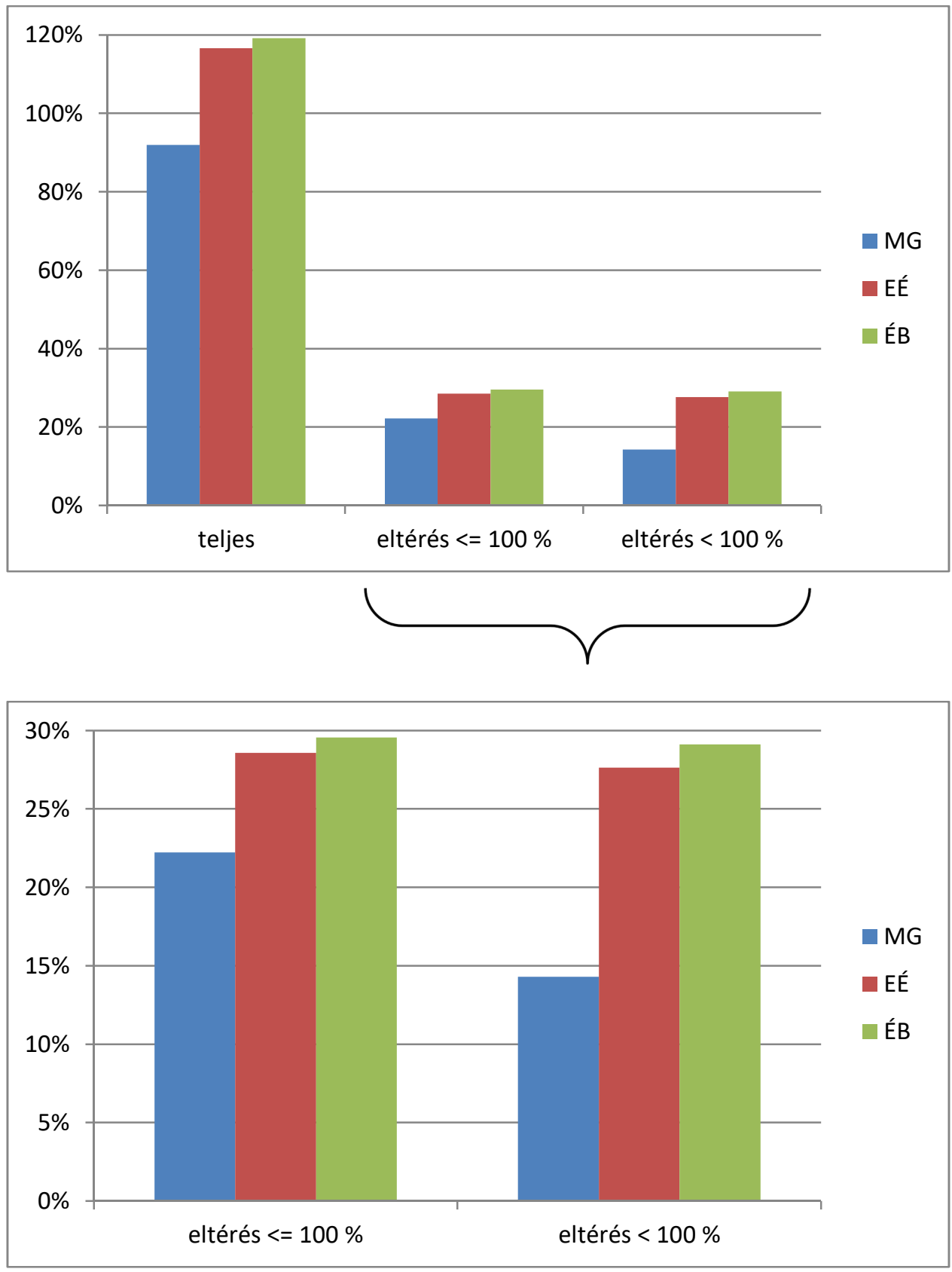

Forrás: AB:TAO alapján saját szerkesztés

Az eredmények alapján a H3 hipotézist elfogadottnak tekintem. 


\section{H4 hipotézis: Magyarországon a kisebb vállalkozásoknak szignifikánsan kevesebb adóalap módosító tétele van a nagyobb vállalkozásokkal összehasonlítva.}

A 2015-ös évi társasági adóalap meghatározása során a számviteli adózás előtti eredményből kiindulva 41 csökkentő és 33 növelö, azaz összes 74 módosító tétel figyelembe vételével juthatunk el az adóalapig. A gazdálkodókat a méret alapján három csoportba rendezve átlagos adóalap korrekciójuk számát mutatja a következő táblázat.

42. táblázat: Adóalap módosító tételek átlagos száma

\begin{tabular}{|l|r|r|r|}
\hline \multirow{2}{*}{ Kategória } & \multicolumn{3}{|c|}{ Teljes } \\
\cline { 2 - 3 } & Csökkentő & \multicolumn{1}{|c|}{ Növelö } & Összesen \\
\hline MG & 0,78 & 0,96 & 1,74 \\
\hline EÉ & 1,74 & 2,32 & 4,05 \\
\hline ÉB & 2,69 & 3,58 & 6,27 \\
\hline \hline Összesen & 0,87 & 1,08 & 1,95 \\
\hline
\end{tabular}

Forrás: AB: TAO alapján saját szerkesztés

Az összesen 41 adóalap csökkentő tétel közül a mikrogazdálkodóknál legfeljebb 6, az egyszerüsített éves beszámoló készítőknél legfeljebb 8, míg az éves beszámolót készítőknél volt egy olyan gazdálkodó, akinek 13 csökkentő tétele volt. A 33 növelö tételből méret szerinti sorrendben legfeljebb 6, 6, illetve 9 került elö egy-egy gazdálkodónál. Az összesített módosító tételek számát tekintve a maximális érték 12, 15, illetve 21. A korrekciós tételek számának eloszlása azonban balra ferde eloszlást mutat, vagyis az előbbi maximális számok egy-egy kirívó esetet jelentenek. Ezt szemlélteti a következő ábra is. 
21. ábra: Gazdálkodók megoszlása az adóalap módosító tételek (teljes) száma szerint

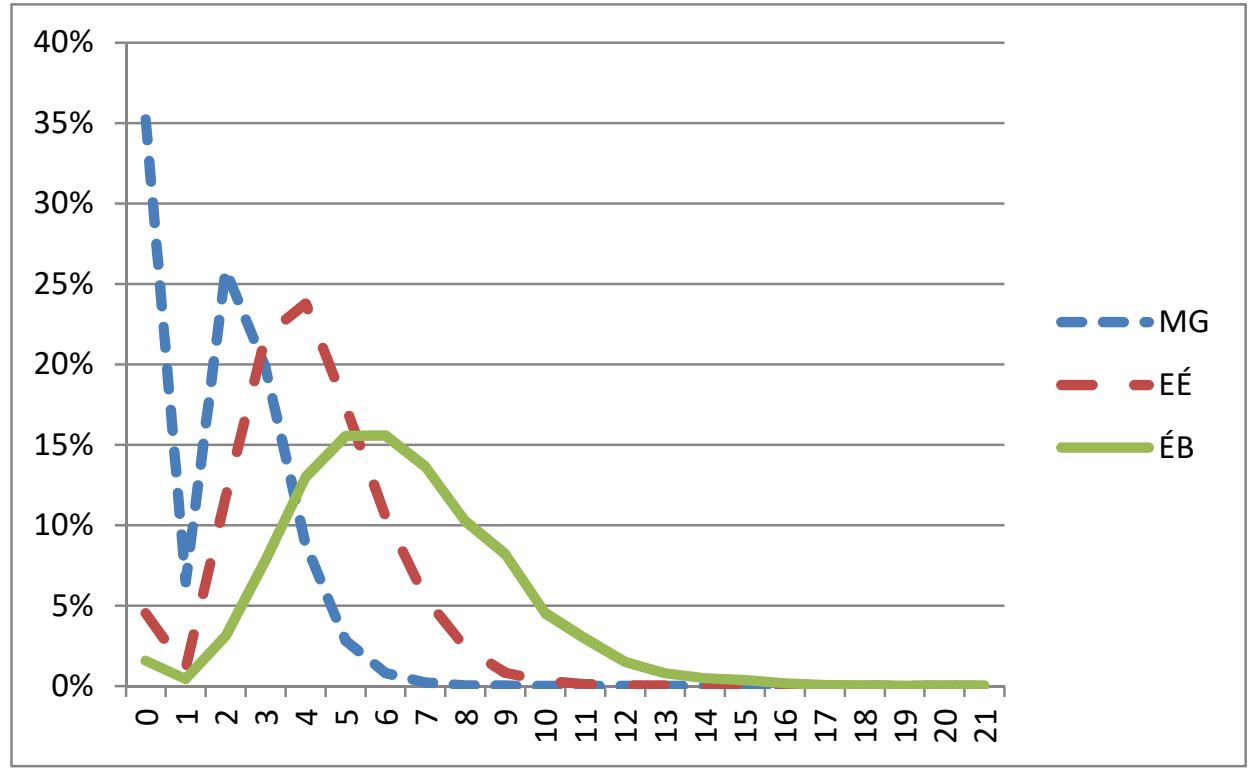

Forrás: AB: TAO alapján saját szerkesztés

Elsőre érdekesnek tűnhet a nulla és kettő közötti visszaesés, vagyis az egy adóalap korrekcióval rendelkező gazdálkodók alacsony száma. A válasz az értékcsökkenési leírás kezelésében rejlik, ez ugyanis páros tétel. Adóalap növelőnek minősül a számviteli törvény szerint meghatározott értékcsökkenés és adóalap csökkentőnek a társasági adótörvény által elismert (a TAO törvény 1. és 2. melléklete szerint meghatározott) értékcsökkenés. Így ha egy vállalkozás rendelkezik olyan tárgyi eszközzel vagy immateriális jószággal, amely után terv szerinti értékcsökkenést számol el, akkor már biztosan lesz két adóalap korrekciós tétele.

Megvizsgálva az adatbázist ilyen szempontból megállapítható, hogy a gazdálkodók egy jelentős részénél - főként mikrogazdálkodók - esetében nincs tárgyi eszköz, így nem jelenik meg az értékcsökkenés miatti korrekció, illetve megegyezik a számvitelileg elszámolt és az adótörvény által elismert értékcsökkenés értéke. Itt visszaköszön a H1 hipotézis esetén vizsgált számviteli politikai döntés, amely szerint az értékcsökkenés meghatározása már eleve az adótörvény által ismert kulcs alapján történik. Ezen helyzetben lévő („Egyező”) vállalkozások aránya szintén összefüggésben van a vállalkozás méretével. Összességében a mikrogazdálkodók $83 \%$-ánál nem jelent valódi korrekciót az értékcsökkenés, míg az egyszerüsített éves beszámoló készítőinél $36 \%$, az éves beszámolót készítők esetén mindösszesen $18 \%$-nál áll fenn. 
43. táblázat: Értékcsökkenés adóalap módosító hatása

\begin{tabular}{|c|c|c|c|c|c|c|c|c|}
\hline \multirow[b]{2}{*}{ Kategória } & \multicolumn{4}{|c|}{ Gazdálkodók száma } & \multicolumn{4}{|c|}{ Gazdálkodók aránya } \\
\hline & Nincs & Egyező & $\begin{array}{c}\text { Nem } \\
\text { eltérő }\end{array}$ & Eltérö & Nincs & Egyező & $\begin{array}{l}\text { Nem } \\
\text { eltérö }\end{array}$ & Eltérő \\
\hline MG & 167205 & 157844 & 325049 & 64416 & $43 \%$ & $41 \%$ & $83 \%$ & $17 \%$ \\
\hline EÉ & 1478 & 6940 & 8418 & 15249 & $6 \%$ & $29 \%$ & $36 \%$ & $64 \%$ \\
\hline ÉB & 188 & 1146 & 1334 & 6057 & $3 \%$ & $16 \%$ & $18 \%$ & $82 \%$ \\
\hline Összesen & 168871 & 165930 & 334801 & 85722 & $40 \%$ & $39 \%$ & $80 \%$ & $20 \%$ \\
\hline
\end{tabular}

Nem eltérő = nem módosító = Nincs+Egyező

Eltérő = módosító

Forrás: AB: TAO alapján saját szerkesztés

Amennyiben az adóalap korrekciós tételek közül kihagyjuk azon eseteket, amikor az értékcsökkenésnek nincs adóalap módosító hatása (azonos összegủ csökkentő és növelö tételként jelenik meg), akkor a mikrogazdálkodóknál jelentősen - majdnem felével - csökken az átlagos tételszám, egyszerüsített éves beszámolósoknál 1/6-dal, míg az éves beszámolót készítőknél mindösszesen 1/19-del lett kevesebb.

44. táblázat: Adóalap módosító tételek átlagos száma

\begin{tabular}{|l|r|r||r|}
\hline \multirow{2}{*}{ Kategória } & \multicolumn{3}{|c|}{ Écs egyezöség nélkül } \\
\cline { 2 - 4 } & Csökkentő & \multicolumn{1}{|c|}{ Növelö } & Összesen \\
\hline MG & 0,37 & 0,55 & 0,93 \\
\hline EÉ & 1,44 & 2,02 & 3,47 \\
\hline ÉB & 2,54 & 3,42 & 5,96 \\
\hline \hline Összesen & 0,47 & 0,69 & 1,16 \\
\hline
\end{tabular}

Forrás: AB: TAO alapján saját szerkesztés 
22. ábra: Gazdálkodók megoszlása az adóalap módosító tétek (écs egyezőség nélküli) száma szerint

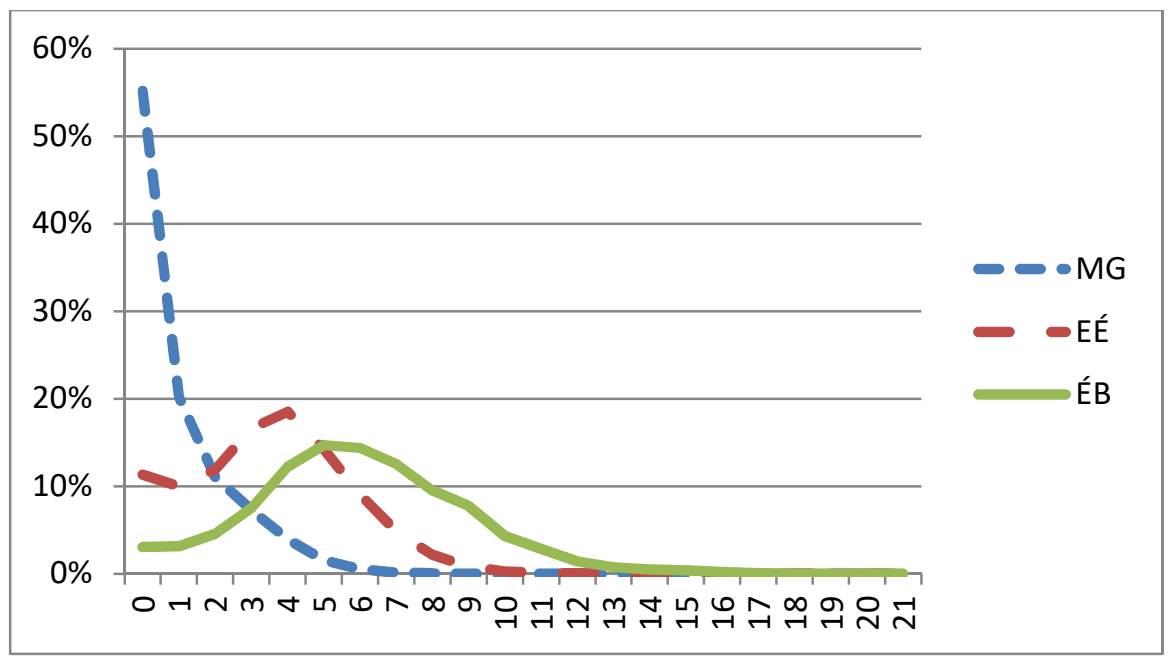

Forrás: AB: TAO alapján saját szerkesztés

A kategóriák közötti különbség mérésére varianciaanalízist alkalmaztam (módszertani leírását lásd H1-H2 hipotézisnél), amely alapján megállapítható, hogy szignifikáns különbség van az egyes kategóriák között és a gazdálkodók mérete szerint egyértelmüen növekvő sorrendbe rendezhetőek az adóalap módosító tételeik száma szerint (mind a teljes, mind az értékcsökkenés egyezőségével korrigált számítások szerint is).

23. ábra: Gazdálkodók adóalap módosító tételeinek átlagos száma

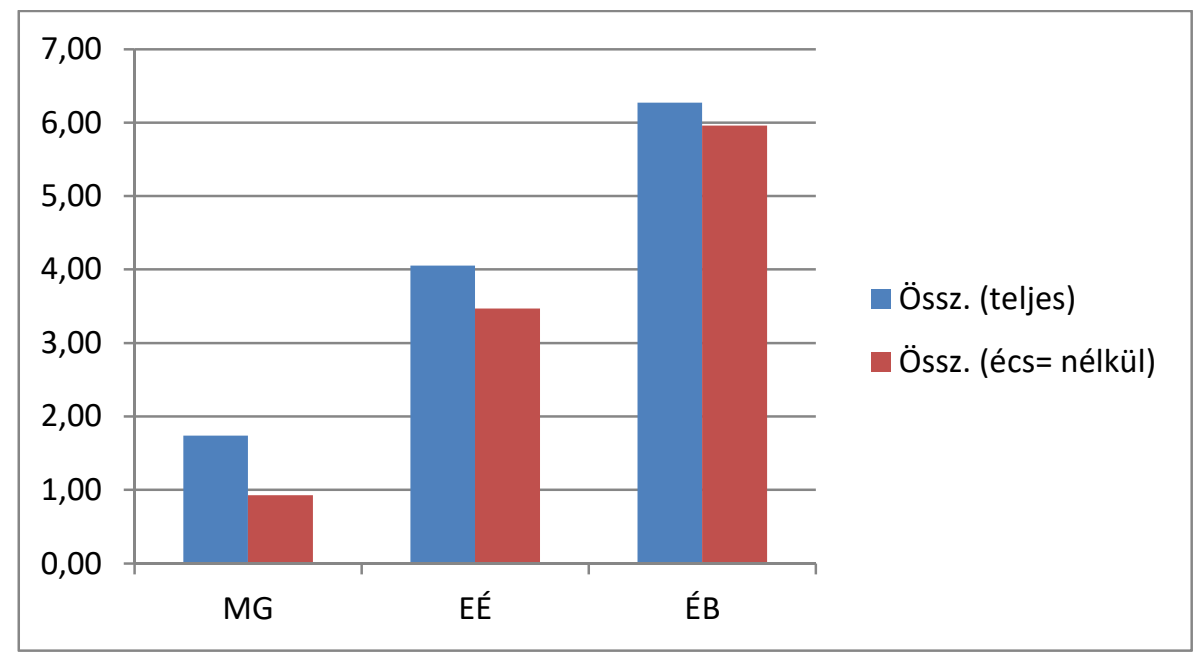

Forrás: AB: TAO alapján saját szerkesztés

Ezek alapján a H4 hipotézist elfogadottnak tekintem. 


\section{A nemzetközi szabályozásra vonatkozó kutatás (H5)}

Nemzeti szinten az egyes országok számviteli szabályozásában valamilyen módon megjelennek méret alapján való kategóriák és ehhez kapcsolódóan a kisebb vállalkozásokra vonatkozóan bizonyos szintü egyszerüsítések. Ezek mértéke azonban meglehetősen eltérő, ugyanakkor valamilyen szinten kategóriák állapíthatóak meg.

\section{H5 hipotézis: Az egyes országok csoportokba rendezhetőek a KKV-ra vonatkozó számviteli szabályozásuk alapján.}

A vizsgálatot első körben az Európai Bizottság megrendelésére 2011-ben készült nemzetközi kutatás (CNA Interpreta S.r.l. [2011]: Study on Accounting requirements for SMEs) adataiból kiindulva végezetem el. A tanulmányban 20 országra vonatkozóan találhatóak a számviteli beszámoltatás rendszerét jellemző adatok, így a beszámoló felépítése, elemei, határértékek, közzétételre vonatkozó előírások, könyvvizsgálat kötelezettség. A tanulmányból kigyüjtöttem a számviteli beszámoltatás rendszerét jellemző adatokat az egyes országokra vonatkozóan. Mivel a kutatásban nem szerepelt Magyarország, így az adatbázist kiegészítettem a hazánkra vonatkozó adatokkal.

Klaszterelemzést hajtottam végre a számviteli határértékekre vonatkozóan vizsgálva, hogy mely országok szabályozása mutat hasonlóságot.

A vizsgálat során megállapítottam, hogy 11 ország esetében (köztük hazánkban) nem jelenik meg a számviteli szabályozásban a kisvállalkozásra vonatkozóan számviteli határérték. 10 ország esetében találunk valamilyen értéket, amely alapján 4 klaszter azonosítható be. A vizsgálatba bevontam az Európai Unió új számviteli irányelvében rögzített értéket is, mint viszonyítási pontot.

A kapott dendrogram demonstrálja a csoportokat és az egyes országok közötti különbséget, a táblázatban lévő adatok összefoglalásával kívánok rámutatni, hogy az EU határértékhez képest mekkora az árbevétel, illetve a mérlegföösszeg értékaránya. Spanyolország kiugróan az alacsony értékeknek köszönhetően került külön klaszterbe. 
24. ábra: Kisvállalkozások határérték klaszter elemzésének dendrogramja

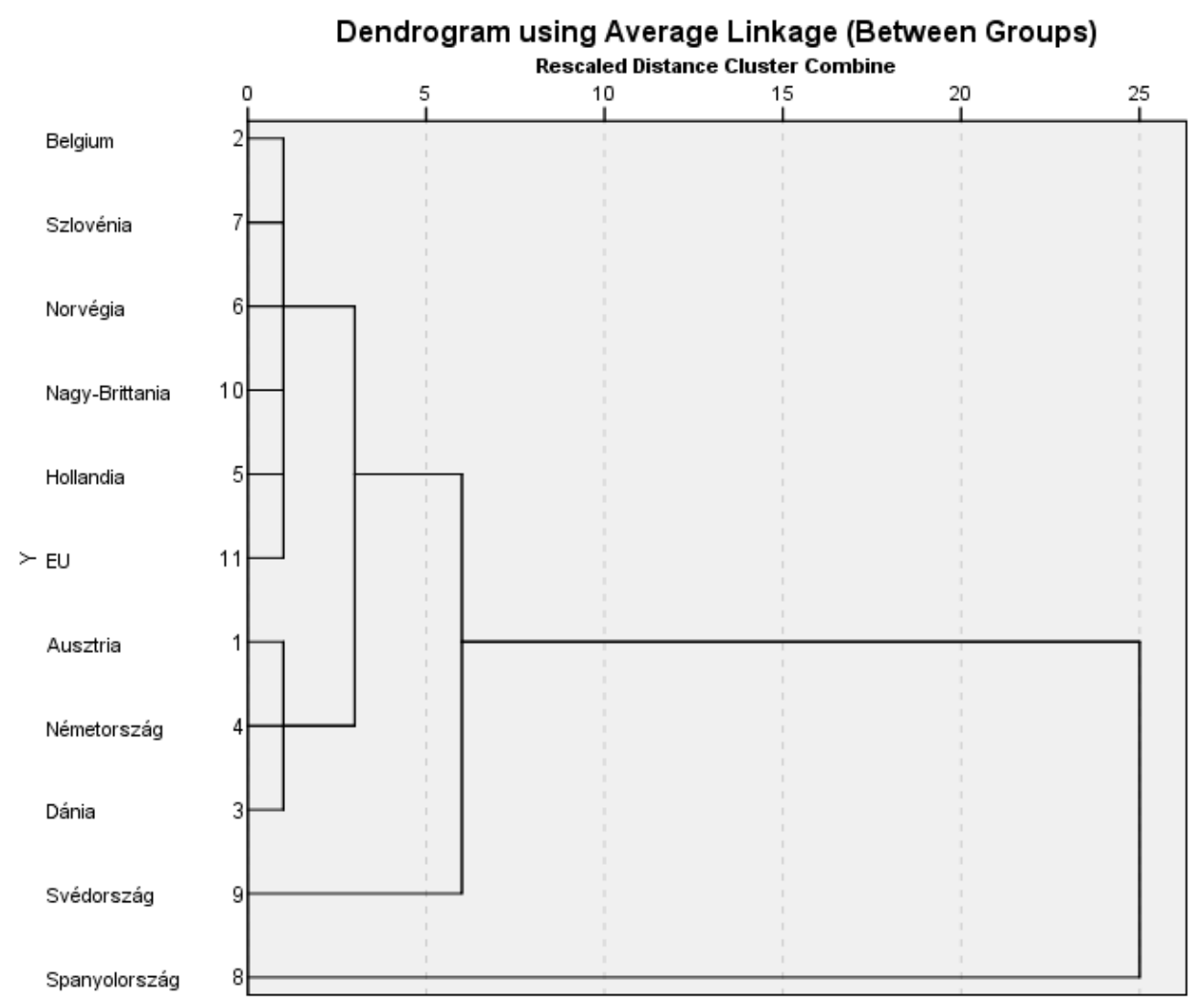

Forrás: AB:NK alapján saját szerkesztés

45. táblázat: Kisvállalkozások határértéke

\begin{tabular}{|c|l|r|r|r|r|}
\hline Klaszter & \multicolumn{1}{|c|}{ Ország } & Létszám & Árbevétel & Mérlegföösszeg & Érték arány \\
\hline 1 & Spanyolország & 10 & 2000 & 1000 & 0,25 \\
\hline 2 & Svédország & 50 & 4785 & 2392 & 0,60 \\
\hline \multirow{3}{*}{3} & Norvégia & 50 & 7048 & 3525 & 0,88 \\
\cline { 2 - 7 } & Nagy-Britannia & 50 & 7130 & 3576 & 0,89 \\
\cline { 2 - 6 } & Belgium & 50 & 7300 & 3650 & 0,91 \\
\cline { 2 - 7 } & Szlovénia & 50 & 7300 & 3650 & 0,91 \\
\cline { 2 - 6 } & EU & $\mathbf{5 0}$ & $\mathbf{8 0 0 0}$ & $\mathbf{4 0 0 0}$ & $\mathbf{1 , 0 0}$ \\
\cline { 2 - 6 } & Hollandia & 50 & 8800 & 4400 & 1,10 \\
\hline \multirow{3}{*}{4} & Dánia & 50 & 9677 & 4838 & 1,21 \\
\cline { 2 - 6 } & Ausztria & 50 & 9680 & 4840 & 1,21 \\
\cline { 2 - 6 } & Németország & \multicolumn{5}{|c|}{50} & 9680 & 4840 & 1,21 \\
\hline \multirow{2}{*}{0} & Csehország, Észtország, Franciaország, Görögország, Lengyelország, \\
& Litvánia, Magyarország, Olaszország, Portugália, Románia, Szlovákia \\
\hline
\end{tabular}

Forrás: AB:NK alapján saját szerkesztés 
A közepes vállalkozások határértékeire elvégezve a vizsgálatot, megállapítható, hogy itt még kevesebb ország rendelkezik számvitelen belül meghatározott és értelmezett határértékkel, Itt már csak 3 klaszter azonosítható (azokon kívül, akik nem rendelkeznek határértékkel).

25. ábra: Közepes vállalkozások határérték klaszter elemzésének dendrogramja

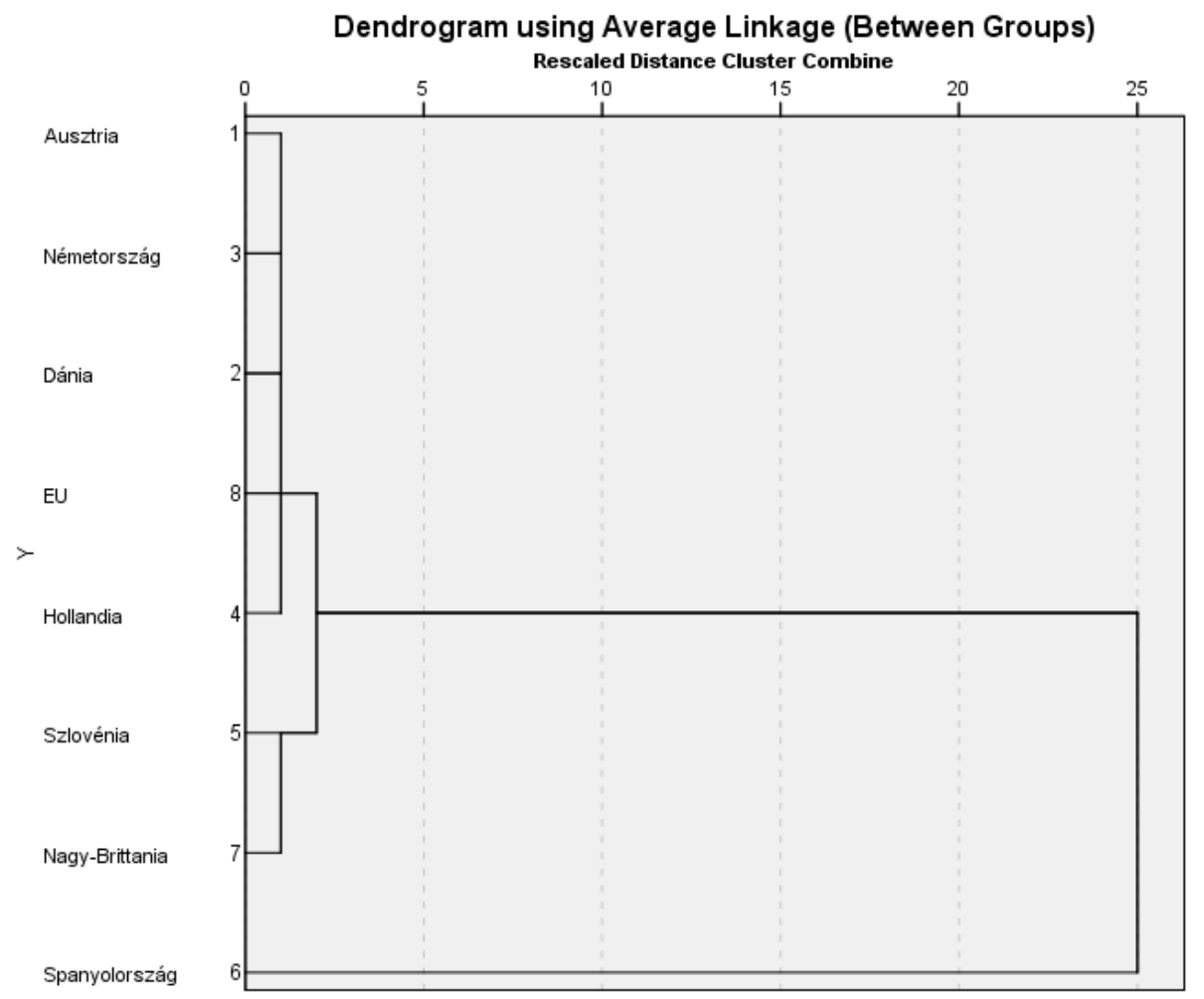

Forrás: AB:NK alapján saját szerkesztés

46. táblázat: Közepes vállalkozások határérték

\begin{tabular}{|c|l|r|r|r|r|}
\hline Klaszter & \multicolumn{1}{|c|}{ Ország } & Létszám & Árbevétel & Mérlegföösszeg & Érték arány \\
\hline 1 & Spanyolország & 50 & 5750 & 2850 & 0,14 \\
\hline \multirow{2}{*}{2} & Nagy-Britannia & 250 & 28412 & 12900 & 0,71 \\
\cline { 2 - 7 } & Szlovénia & 250 & 29200 & 14600 & 0,73 \\
\hline \multirow{4}{*}{3} & Hollandia & 250 & 35000 & 17500 & 0,88 \\
\cline { 2 - 7 } & Dánia & 250 & 38438 & 19219 & 0,96 \\
\cline { 2 - 7 } & Ausztria & 250 & 38500 & 19250 & 0,96 \\
\cline { 2 - 7 } & Németország & 250 & 38500 & 19250 & 0,96 \\
\cline { 2 - 6 } & EU & $\mathbf{2 5 0}$ & $\mathbf{4 0 ~ 0 0 0}$ & $\mathbf{2 0 ~ 0 0 0}$ & $\mathbf{1 , 0 0}$ \\
\hline \multirow{2}{*}{0} & $\begin{array}{l}\text { Belgium, Csehország, Észtország, Franciaország, } \\
\text { Lengyelország, Lörögország, } \\
\end{array}$ & $\begin{array}{l}\text { Litvánia, Magyarország, Norvégia, } \\
\text { Portugália, Románia, Svédország, Szlovákia }\end{array}$ \\
\hline
\end{tabular}

Forrás: AB:NK alapján saját szerkesztés 
A klaszterek összetételét tekintve nincs nagy változás, csak kiestek a nem szabályozók. Megfigyelhető ugyanakkor, hogy amíg korábban az EU érték középen helyezkedett el, a középvállalkozások esetén mindenkit meghaladóan magasra került a határérték.

Ezt követően magára a beszámolóra vonatkozó határértékek alapján végeztem el a klaszterelemzést, vizsgálva, hol húzzák meg az egyszerüsítési lehetőség határát. Magyarország az egyszerüsített éves beszámoló határértéke alapján került be a vizsgálatba.

26. ábra: Beszámoló határérték klaszter elemzésének dendrogramja

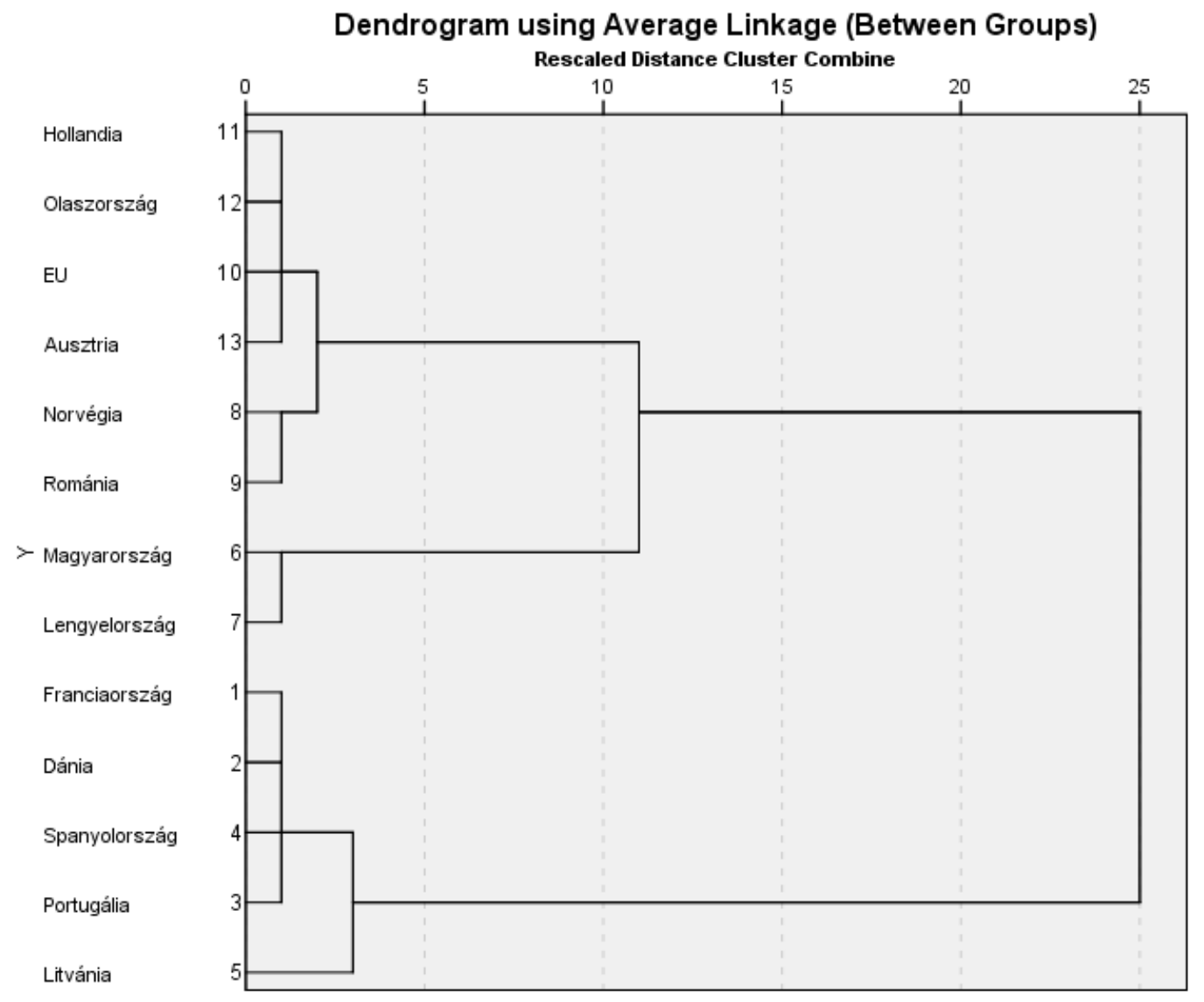

Forrás: AB:NK alapján saját szerkesztés 
Itt már változatosabb a kép 5 klaszter azonosítható a határértékkel rendelkező országokra vonatkozóan.

1. csak mikro szinten enged egyszerüsítést

2. létszám mikro, de magasabb az árbevételi és mérlegföösszegre vonatkozó határérték

3. létszám kisvállalkozói, árbevétel és mérlegföösszeg alapján az EU szint fele

4. kisebb eltérés az EU szinthez képest

5. EU szintnek megfelelő érték

47. táblázat: Beszámoló határérték - EU

\begin{tabular}{|c|c|c|c|c|c|c|c|c|}
\hline \multirow{2}{*}{ Klaszter } & \multirow{2}{*}{ Ország } & \multicolumn{3}{|c|}{ Érték } & \multicolumn{4}{|c|}{ Érték-arány } \\
\hline & & Árb. & Mfö. & Létsz. & Árb. & Mfö. & Létsz. & Átlag \\
\hline \multirow{4}{*}{1} & Franciaország & 534 & 267 & 10 & 0,07 & 0,07 & 0,2 & 0,11 \\
\hline & Dánia & 1342 & 537 & 10 & 0,17 & 0,13 & 0,2 & 0,17 \\
\hline & Portugália & 1000 & 500 & 20 & 0,13 & 0,13 & 0,4 & 0,22 \\
\hline & Spanyolország & 2000 & 1000 & 10 & 0,25 & 0,25 & 0,2 & 0,23 \\
\hline 2 & Litvánia & 2896 & 1737 & 15 & 0,36 & 0,43 & 0,3 & 0,37 \\
\hline \multirow{2}{*}{3} & Magyarország & 3333 & 1667 & 50 & 0,42 & 0,42 & 1 & 0,61 \\
\hline & Lengyelország & 4000 & 2000 & 50 & 0,50 & 0,50 & 1 & 0,67 \\
\hline \multirow{2}{*}{4} & Norvégia & 7048 & 3525 & 50 & 0,88 & 0,88 & 1 & 0,92 \\
\hline & Románia & 7300 & 3650 & 50 & 0,91 & 0,91 & 1 & 0,94 \\
\hline \multirow{4}{*}{5} & $\mathbf{E U}$ & 8000 & 4000 & 50 & $\mathbf{1 , 0 0}$ & 1,00 & 1 & 1,00 \\
\hline & Hollandia & 8800 & 4400 & 50 & 1,10 & 1,10 & 1 & 1,07 \\
\hline & Olaszország & 8800 & 4400 & 50 & 1,10 & 1,10 & 1 & 1,07 \\
\hline & Ausztria & 9680 & 4840 & 50 & 1,21 & 1,21 & 1 & 1,14 \\
\hline 0 & \multicolumn{8}{|c|}{$\begin{array}{l}\text { Belgium, Csehország, Észtország, Görögország, Nagy-Britannia, } \\
\text { Németország, Svédország, Szlovákia, Szlovénia }\end{array}$} \\
\hline
\end{tabular}

Forrás: AB:NK alapján saját szerkesztés 
27. ábra: A beszámoló átlagos értékhatárai az EU értékhatáraihoz viszonyítva

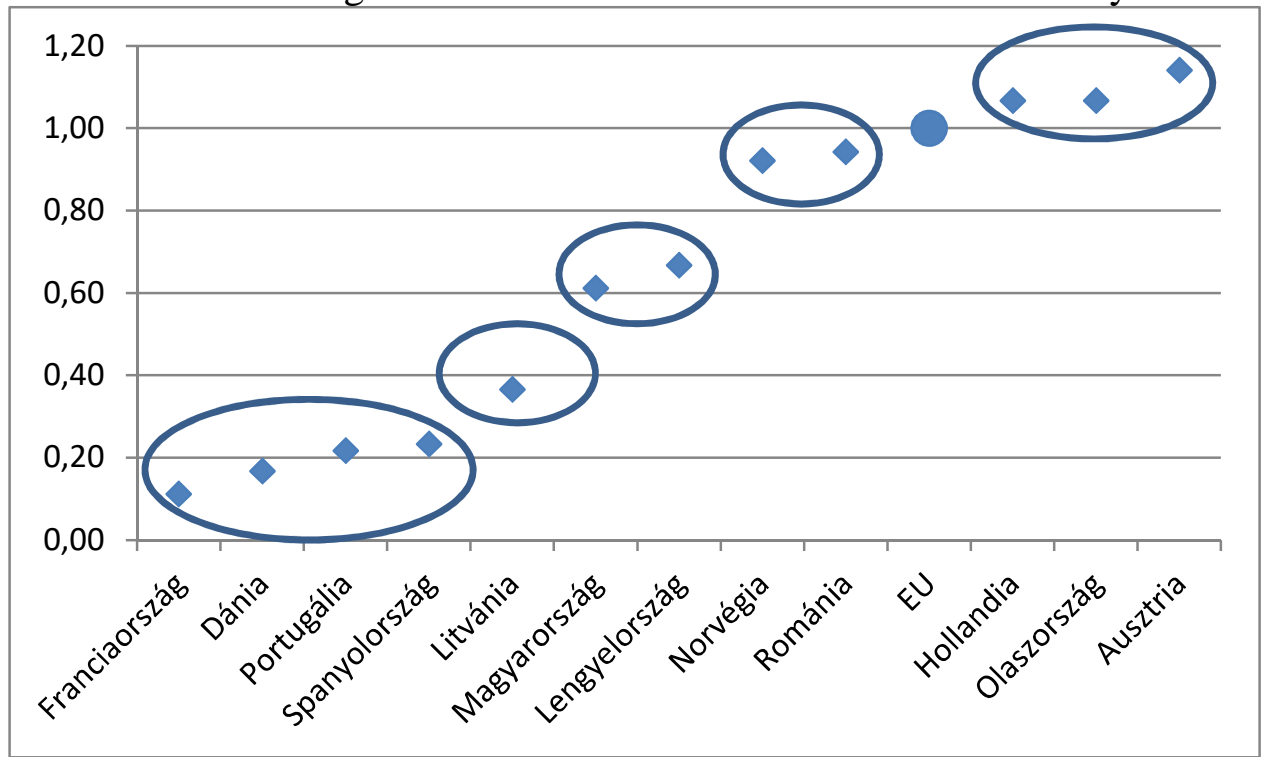

Forrás: AB:NK alapján saját szerkesztés

A jogi forma (korlátolt felelősség, korlátlan felelősség, egyéni vállalkozás) alapján további vizsgálatok lehetségesek.

\section{A kapott eredmények alapján a H5 hipotézist elfogadottnak tekintem.}

Az új számviteli EU irányelv elfogadásával és a tagállamok jogrendjébe való átültetésével azonban várhatóan csökkennek ezek a különbségek. A többség az EU-s határértékeket vette át (ahogy Magyarország is), így ebben már nem lesznek különbségek.

A közepes méretü vállalkozásokra viszonylag egységes szabályozás kezd kialakulni, azonban a kis-, de föként a mikrogazdálkodóknál nem ennyire homogén a kép. Szinte mindenki máshogy látja az egyszerüsítéseket.

Nagyobb eltérések az alábbi területeken vannak: kötelező számlatükör, beszámolónak részei (kell-e készíteni cash flow kimutatást, saját tőke változás kimutatást, kiegészítő megjegyzéseket, menedzsment riportot), kötelező-e a közzététel, a könyvvizsgálat. 


\section{AZ EREDMÉNYEK ÖSSZEFOGLALÁSA ÉS KÖVETKEZTETÉSEK}

A gazdálkodóknak a vagyoni, pénzügyi és jövedelmi helyzetükről a számviteli beszámoló keretében kell információt szolgáltatni az érdekhordozóknak. A beszámoló szabályozásában mindig is megjelentek a kisebb vállalkozásokra vonatkozó egyszerüsítési lehetőségek (egyszerüsített beszámoló, egyszerüsített éves beszámoló, illetve annak sajátos és mikrogazdálkodói változata) és a közelmúltban is történtek ez irányú változtatások: az Európai Unió új számviteli irányelve vagy a magyarországi mikrogazdálkodói kormányrendelet. A kutatásomban a kisvállalkozások beszámolási rendszerét vizsgáltam három területre felállított hipotézis szerint.

Az első két hipotézis a számviteli politikai döntéseket vizsgálta a vállalatmérettel összefüggésben. Az elemzésben a gazdálkodókat a beszámoló készítési határértékek alapján két csoportba soroltam, egyszerüsített éves beszámolót (kisebb) és éves beszámolót készítő (nagyobb) vállalat. A mintában szereplő cégek beszámolójából számított statisztikák és a varianciaanalízis alapján igazoltam, hogy a kisebb vállalkozások inkább az egyszerübb megoldásokat választják a számviteli politikájuk kialakítása során (H1 hipotézis) és kevésbé élnek a nem kötelezően alkalmazandó lehetőségekkel (H2 hipotézis). Ezen állításokat megerősítették a könyvelőirodák vezetőivel készített mélyinterjúk is, amelyek emellett rávilágítottak arra is, hogy a kisebb vállalkozásoknál sok esetben fel sem merülnek ezek a kérdések, mivel nem rendelkeznek a döntéshez kapcsolódó vagyoni elemmel. Ezen területek közül néhányról a társasági adóbevallások adatbázisa is tartalmazott információt, amelyekböl ugyanezekre a következtetésekre jutottam.

A kutatás eredményei alapján megállapítható, hogy a kisebb vállalkozások a gyakorlatban eddig is nagyrészt a 2013-ban bevezetett Mikrogazdálkodói egyszerüsített éves beszámolóban rögzített eljárásokat alkalmazták, így ebből a szempontból ez nem hozott jelentős egyszerüsítést, hanem a meglévő gyakorlatot szentesítette. A könyvelőkkel folytatott mélyinterjúk során kirajzolódott, hogy igazi egyszerűsítés a mikrogazdálkodói beszámolónál az év végi zárlati munkák során (pl. időbeli 
elhatárolások kezelése) jelentkezik, illetve abban, hogy nem kell kiegészítő mellékletet készíteni.

A kutatás további iránya lehetne, hogy van-e különbség ezen a területen a gazdálkodók tevékenységi köre szerint.

A számviteli beszámolóban történő információközlés mellett külön megjelenik még az adóbevallásokban történő adatszolgáltatás is. A H3 és a H4 hipotézisemben a számviteli beszámoló és a társasági adóbevallás kapcsolatát vizsgáltam a vállalati mérettel összefüggésben. A felhasznált adatbázis (társasági adóbevallások) jellege miatt itt már lehetőség volt a kisebb vállalkozásokon belül mikrogazdálkodók elkülönítésére, ami ezáltal mélyebb elemzést tett lehetővé.

A vizsgálat rámutatott arra, hogy a mikrogazdálkodóknál 139790 esetben (35,9\%) nincs eltérés a számviteli (adózás előtti eredmény) és az adózási (adóalap) jövedelemértelmezés között, míg az egyszerüsített éves beszámolót készítő vállalkozásoknál ezen adat 6,9\%, az éves beszámoló esetén 1,8 \%. A relatív jövedelemeltérés vizsgálatánál megállapítottam, hogy - az extrém eseteket kizárva - a mikrovállalkozásoknál szignifikánsan kisebb az eltérés, mint az egyszerüsített éves vagy éves beszámolót készítőknél.

Az társasági adóalapot a számviteli adózás előtti eredményből kiindulva az adóalap módosító tételek segítségével kell meghatározni. A 2015-ben hatályos jogszabály 41 csökkentő és 33 növelő tételt határozott meg, amelyek vizsgálatára az adatbázis lehetőséget teremtett. Megállapítottam, hogy a gazdálkodók méretével összefüggésben van egyrészt az, hogy hány százalékuknak nincs egyáltalán adóalap korrekciója (mikrogazdálkodói beszámoló 35,2 \%, egyszerüsített éves beszámoló 4,5\%, éves beszámoló 1,6\%), másrészt hogy átlagosan hány darab korrekciós tételt veszek figyelembe az adóalap megállapítások során (sorrendben 1,74; 4,05 és 6,27). A korrekciók legtöbb esetben az értékcsökkenés miatti azonos összegü növelő és csökkentő tételekben jelentkeztek, ez a gazdálkodó típusok $41 \%$, $29 \%$ és $16 \%$-ánál fordult elő. Ha ezt kivesszük, akkor az adóalap korrekcióval nem rendelkező száma jelentősen megnő $(55,2 \% ; 11,3 \% ; 3,1 \%)$ és az átlagos adóalap korrekciók száma is jelentősen lecsökken $(0,93 ; 3,47$ és 5,96) föként a mikrogazdálkodók körében. 
A kutatási eredmények rámutattak, hogy a vállalkozások egy jelentős rétegénél nem különöl el a számvitelileg kimutatott eredmény és az adóalap, ez felveti egy egyszerüsített társasági adóbevallás bevezetésének lehetőségét.

Az adó és számvitel kapcsolatának vizsgálatánál a különféle kisvállalkozásokra kialakított adózási rendszer és a kapcsolódó számviteli kötelezettségek rendszerbe foglalása és a hatások modellezése hozzájárulhat a rendszer fejlesztéséhez. A jelenleg meglévő három adózási filozófiára épülő rendszer (tételes adó - kisvállalkozások tételes adója, bevétel alapú - egyszerüsített vállalkozói adó, jövedelem alapú - társasági adó) és a hozzájuk kapcsolódó információigények egyértelmü leszabályozása sokat tisztítana a kissé bonyolult rendszeren.

A magyarországi helyzet vizsgálatát követően nemzetközi összehasonlításban is megvizsgáltam a számviteli szabályozásban lévő egyszerüsítési lehetőségekkel kapcsolatos kvantitatív és kvalitatív kritériumokat.

A gazdálkodó egységek jogi formája (korlátolt felelősségű társaság, korlátlan felelősségü társaság, egyéni vállalkozás) és mérete (közepes, kicsi, mikro) alapján összehasonlítottam a számviteli beszámoltatás rendszerét jellemző adatokat (beszámoló felépítése, határértékek, közzététel, könyvvizsgálat) az adatbázisban szereplő 20 ország viszonylatában Magyarországgal kiegészítve. A minősítési jellemzők önálló elemzése után klaszterelemzéssel csoportosítottam az országokat. Az Egyesült Királyság kilóg a vizsgált országok közül, ami számviteli rendszerbeli különbséggel (angolszász) és kisvállalkozásokra vonatkozó külön szabályozásával magyarázható. A többi ország négy csoportba sorolható:

1. Van egyszerüsítés, a határértékek az uniós irányelvben szereplő kisvállalkozói érték körül vannak: Ausztria, Hollandia, Olaszország, Románia és Norvégia

2. Van egyszerüsítés, a határértékek az uniós irányelvben szereplő határértéknek a felénél vannak: Lengyelország, Magyarország

3. Csak mikroszinten van egyszerüsítés: Franciaország, Dánia, Portugália, Spanyolország, Litvánia

4. Nincs egyszerűsítés: Belgium, Csehország, Észtország, Görögország, Németország, Svédország, Szlovákia, Szlovénia 
A 2013-ban elfogadott új uniós számviteli irányelv többek között a kisvállalkozásokra vonatkozó követelményrendszer harmonizálását tűzte ki célul és egyszerüsítési, mentesítési lehetőségeket enged számukra. A tagállamoknak meg kellett feleltetniük a nemzeti jogszabályaik erre vonatkozó részeit az új irányelvnek. További kutatási irány lehet annak feltérképezése, hogy a mennyire közeledett az egyes országok számviteli beszámoltatásának rendszere egymáshoz, különös tekintettel a KKV-kra vonatkozó szabályozás tekintetében.

Másik iránya a nemzetközi kutatásoknak a KKV IFRS elterjedésének vizsgálata, mennyire épül be azon országok esetén a számviteli rendszerbe, ahol a teljes IFRS alkalmazás kötelező vagy megengedett. Milyen vállalkozások (méret, jogi forma) esetén kerül sor a használatra és mi az a szint, ahol az országok egyszerübb számviteli beszámolást írnak elő a vállalkozásaik számára, megtartva saját nemzeti szabályozásuk keretein belül.

A számviteli beszámoltatás területén hiába történik egyszerüsítés, ha más területek - föleg az adózás - nem követik azt le és sokszor mélyebb, részletesebb adatokat kérnek, mint amit a számvitel elöír. Gyakran ugyanazon adatokat kell szolgáltatni a különböző hatóságok irányába (pl. adóhivatal, statisztikai hivatal, céginformációs szolgálat). Igazi könnyítést az jelentene, ha egy helyre történő adatszolgáltatást követően a hivatalok megosztanák egymás között az adatokat. Ennek egyik esete lehetne a mikrogazdálkodókra vonatkozóan a számviteli beszámoló közzétételére való kötelezettség alóli mentesítése olyan formában, hogy a benyújtott társasági adóbevallás releváns adatait hozzák nyilvánosságra (adóhivatal továbbítja a céginformációs szolgálatnak).

Remélem a kutatásom eredményeivel sikerül hozzájárulnom a számviteli beszámoltatás rendszerének fejlődéséhez. 


\section{FELHASZNÁLT IRODALOM}

Adorján Csaba [2013]: Korszakváltás a számvitel szabályozásában (Könyvvizsgálók lapja; 2. évfolyam, 1. szám; pp.12-13.)

Albu, C. N. - Albu, N. - Fekete, P-P. Sz. - Girbina, M. M. - Selimoglu, S. K - Kovács, D. M. - Lukács, J. - Mohl, G. - Müllerová, L. - Paseková, M. - Arsoy, A. P. - Sipahi, B. - Strouhal, J. [2013]: Implementation of IFRS for SMEs in Emeging Economies: Stakeholder Perceptions in the Czech Republic, Hungary, Romania and Turkey (Journal of International Financial Management \& Accounting 24:2 pp. 140-175)

Allee, K. D. - Yohn, T. L. [2009]: The demand for financial statments in an unregulated environment: An examination of the production and use of financial statements by privately held small businesses (The Accounting Review; Vol. 84. No. 1; pp. 1-25.)

American Accounting Assosiantion's Financial Accounting Standard Committee [2006]: Financial accounting and reporting standards for private entities (Accounting Horizons; Vol. 20. No. 2., June; pp. 179-194)

Artsberg, K. [1996]: The link between commercial accoutintg and tax accounting in Sweden (European Accounting Review; Vol. 5., Suppplement, pp. 795-814.)

Babbie, E. [2003]: A társasalomtudományi kutatás gyakorlata (6. átdolgozott kiadás, Balassi Kiadó, Budapest)

Bae, K. - Tan, H. - Welker, M. [2008]: International GAAP Differences: The Impact on Foreign Analysts. (The Accounting Review; Vol. 83, No. 3; pp. 593-628)

Balás Gábor - Vékony András Benjámin [2009]: Az adórendszer hatása a vállalkozás szabadságára - Egy lepapírozott adórendszer költségei, (Közjó és Kapitalizmus Intézet. (http://www.kozjoeskapitalizmus.hu/files/MT16.Balas-Vekony.Ado2008.pdf Letöltés ideje: 2013. március 13.)

Ball. R. [2006]: International Financial Reporting Standards (IFRS): pros and cons for investors (Accounting and Business Research, International Accounting Policy Forum; pp. 5-27)

Baricz Rezső [1997a]: Mérlegtan (Aula Kiadó, Budapest) 
Baricz Rezső [1997b]: A magyar számvitel a nemzetközi és a nemzeti szabályok tükrében. (Számvitel - Adó - Könyvvizsgálat; 39. évfolyam, 10. szám, 1997. október; pp. 410-416.)

Baricz Rezső [2008]: A számvitel súlypontjai (Számvitel - Adó - Könyvvizsgálat; 50. évfolyam, Jubileumi melléklet; pp. 3-6.)

Baricz Rezső [2009]: A számvitel alapjai (Saldo Kiadó, Budapest)

Barth, M. E. [2000]: Valuation-based accounting research: Implications for financial reporting and oppuritinities for future research (Accounting and Finance; 40; pp. 7-31)

Barth, M. E. - Landsman, W. R. - Lang, M. H. [2007]: International Accounting Standards and Accounting Quality (Journal of Accounting Research; Vol. 46. No.3. June; pp. 467-498)

BCE Pénzügyi Számvitel Tanszék [2007] Az adózási és számviteli adminisztráció egyszerüsítése - Tanulmány (kézirat)

Bélafi Dávid [2012]: A számviteli irányelvek felülvizsgálata (Számvitel - Adó Könyvvizsgálat; 54. évfolyam, 7-8. szám; pp. 316-318.)

Beke Jenő [2010a]: Nemzetközi számviteli standardok adaptálásának gyakorlata (Számvitel - Adó - Könyvvizsgálat; 52. évfolyam, 2. szám 2010. február; pp. 90-95.)

Beke Jenő [2010b]: A számvitel globalizálódása és harmonizálódás a regionális (EU) és a nemzetközi összehasonlító vizsgálatok tükrében (Külgazdaság; 54. évfolyam. 2010. május-június; pp. 81-101.)

Benedict, A. - Elliott, B. [2001]: Practical accounting. (FT/Prentice Hall; Harlow)

Bosnyák János [2003]: Számviteli értékelési eljárások hatása a vállalkozások vagyoni, jövedelmi és pénzügyi helyzetére. (Ph.D értekezés, Budapesti Közgazdaságtudományi és Államigazgatási Egyetem)

Bosnyák János [2011]: A számvitel nemzeti és nemzetközi szabályozása (BCE A számvitel szabályozása előadás; Budapest; 2011. szeptember 14.) 
Centre for Strategy \& Evolution Services [2010]: 4th Company Law Directive and IFRS for SMEs - Final report

(http://ec.europa.eu/internal_market/accounting/docs/studies/2010_cses_4th_company_1 aw_directve_en.pdf, Letöltés ideje: 2013. február 12.)

CFFR: A Survey of SME Accounting and Reporting Practices in Austria [2013] (http://siteresources.worldbank.org/EXTCENFINREPREF/Resources/41521171270824012230/6954188-1369301061218/CFRR_SME_Austria_CFR_Study.pdf, Letöltés ideje 2017. február 10.)

Chikán Attila [2008]: Vállalatgazdaságtan (4. átdolgozott, bővített kiadás, Aula Kiadó, Budapest)

Choi, F. D. S. - Meek, G. K. [2011]: International accounting. (Seventh Edition; New Jersey)

CNA Interpreta S.r.1.[2011]: Study on Accounting requirements for SMEs, FINAL REPORT

(http://ec.europa.eu/enterprise/policies/sme/business-environment//files/study_on_ accounting_requirements_for_smes_final_report_en.pdf

Letöltés ideje: 2011. szeptember 21.)

Cuzdriorean, D. D. - Albu, C. N. - Albu, N. [2012]: The relationship between accounting and taxation and the disconnection goal: prudence versus true and fair view (Review of Business Research; Vol. 12. Number 2.; pp. 59-68.]

Cyert, R. M. - Ijiri, Y. [1974]: Problems of Implementing the Trueblood Objectives Report. (Journal of Accounting Research; Vol. 12; Studies on Financial Accounting Objectives 1974; pp. 29-42.)

Deák István [2006]: A megbízható és valós összkép érvényesülési környezete a hazai és nemzetközi számvitel szabályozásában (Ph.D értekezés, Szegedi Tudományegyetem)

Deloitte [2017]: Use of IFRSs by Juricdiction

(https://www.iasplus.com/en/resources/ifrs-topics/use-of-ifrs, Letöltés ideje: 2017. március 20.)

Drever, M. - Stanton, P.- McGovan, S. [2007] Contemporary issues in accountant (Wiley Australia,) 
Eierle, B. - Haller, A. [2009]: Does size influence the suitability of the IFRS for Small and Medium-Size Entities? - Empirical evidence from Germany (Accounting in Europe, Vol. 6.; No.2., 195-230)

Ernst\&Young [2010]: IFRS for small and medium-sized entities. A comparison

with IFRS - the basics

(http://www2.eycom.ch/publications/items/ifrs/sme/2010_ifrs_for_sme/2010_EY_IFRS _for_SMEs.pdf, Letöltés ideje: 2013. február 12.)

Epstein, Barry J. - Mirza, Abbas Ali [2003]: Nemzetközi számviteli standardok. Magyarázatok és alkalmazások (Perfekt, Budapest)

Európai Bizottság [2016]: Accounting guide for SMEs, SME Accounting in Europe: insights provided by a desk research and a survey

(http://ec.europa.eu/growth/tools-databases/newsroom/cf/itemdetail.cfm?item_id=8380, letöltés ideje: 2017. március 20)

Európai Bizottság [2016]: Annual report on European SMEs (http://ec.europa.eu/growth/smes/business-friendly-environment/performance-review2016_en, Letöltés ideje: 2017. április 12.)

Európai Bizottság [2017]: 2016 SBA Fact Sheet Hungary

(http://ec.europa.eu/DocsRoom/documents/22382/attachments/16/translations Letöltés ideje: 2017. április 12.)

Ferenczi András [1998]: Az európai számviteli rendszerek összehasonlítása. (Számvitel és Könyvvizsgálat; 40. évfolyam, 10. szám, 1998. október; pp. 406-411.)

Filyó Janka - László Norbert - Mikáczó Éva [2011a] Helyzetkép a könyvelői szakmáról I. (Számvitel - Adó - Könyvvizsgálat; 53. évfolyam, 3. szám, 2011. március; pp. 126130.)

Filyó Janka - László Norbert - Mikáczó Éva [2011b] Helyzetkép a könyvelői szakmáról II. rész (Számvitel - Adó - Könyvvizsgálat; 53. évfolyam, 4. szám, 2011. április; pp. 184-187.)

Filyó Janka [2012]: A kkv-k számviteli beszámolási rendszere - mühelytanulmány (Számvitel - Adó - Könyvvizsgálat; 54. évfolyam, 7-8. szám) 
Fülbier, R. U. - Gassen, J. [2010]: IFRS for European Small and Medium-Sized Entities? A theoritical and empirical analylis (http://www.de.dgrv.mobi/webde.nsf/7d5e59ec98e72442c1256e5200432395/eeef676b1 f36f7c1c125773c00289240/\$FILE/F\%C3\%BClbier_Gassen_DGRV_Research_Report_ April_2010.pdf Letöltés ideje: 2013. február 12.)

Glautier, M W E - Underdown, B. [2001]: Accounting theory and practice. (7th edition; FT/Prentice Hall; Harlow)

Gray, S. J. [1988]: Towards a theory of cultural influence on the development of accounting systems internationally (Abacus; Vol. 24; pp. 1-15.)

H. Nagy Mária [2010]: Konferencia a kkv-k beszámolójáról (Számvitel - Adó Könyvvizsgálat; 52. évfolyam, 9. szám; pp. 2-3)

Haller, A. [1992]: The relationship of financial and tax accounting in Germany: a major reason for accounting disharmoniny in Europe (International Journal of Accounting, Vol. 27., pp. 10-23.)

Haller, A. - Walton, P. [2003]: Country difference and harmonization, IN: International accounting (Second edition, Thomson Learing, London; pp. 1-34.)

HÉTFA Kutatóintézet [2010]: Az adminisztratív terhek Magyarországon (http://hetfa.hu/wp-content/uploads/HSZH04_Adminterhek_Magyarországon_ISSN.pdf Letöltés ideje: 2011. szeptember 21.)

Hoogendoorn, M. [1996]: Accounting and taxation in Europe - A comparative overview (The European Accounting Review; 5: Supplement; pp. 783-794. )

Hoogendoorn, M. [2006]: International accounting regulation and IFRS implementation in Europe and Beyond - Experience with first-time adoption in Europe (Accounting in Europe; Vol. 3.; pp. 23-26)

IASCF [2003]: Nemzetközi Pénzügyi Beszámolási Standardok 2003: A Nemzetközi Számviteli Standardokkal és Értelmezésekkel egybefoglalva. (Magyar Számvitel Fejlesztéséért Alapítvány; Budapest)

Jermakowicz. E. K. - Epstein, B. J. [2010]: IFRS for SME's - An option for U.S. private entities? (Review of Business; Vol. 30. Issue 2; pp. 72-78.) 
Kántor Béla [2010]: Üzleti információk feldolgozásának lehetőségei a számvitel oldaláról különös tekintettel az informatikai szempontokra (Ph.D értekezés, Miskolci Egyetem)

Kardos Barbara [2011]: Számviteli információs rendszer értékelemzése (Ph.D értékezés, Pécsi Tudományegyetem)

Karlin, B. H. [2009]: Tax recearch (Fourth edition, Pearson Education Ltd., London)

Kazainé Ónodi Annamária [2010]: A nemzetközi számvitel sajátosságai IN: Nemzetközi vállalatgazdaságtan (Alinea Kiadó, Budapest)

Kiss Árpád [2013]: Mikrogazdálkodói számvitel helyett adószámvitelt! (Könyvvizsgálók lapja; 2. évfolyam, 11. szám; pp. 8-9.)

Kotroczó Melitta [2016]: Nagyon népszerü lett a kata a NAV-nál (http://www.uzletresz.hu/penzugy/20160202-kisadozo-vallalkozasok-teteles-adoja-kataadozas-nav-adoszakerto.html, Letöltés ideje: 2017. április 11.)

Kovács Dániel Máté - Mohl Gergely [2011]: Egy felmérés tanulságai. A kkv-knak szóló IFRS-ek Magyarországon. (Számvitel - Adó - Könyvvizsgálat; 53. évfolyam, 6. szám; pp. 280-284.)

Kovács Dániel Máté - Mohl Gergely [2012]: A számvitel és adózás lehetséges összefüggései. (Számvitel - Adó - Könyvvizsgálat; 54. évfolyam; 4. szám; p. 181)

Kovács Dániel Máté [2013]: A valós érték számviteli szerepe és alkalmazása a magyar szabályozási környezetben (Ph.D értekezés, Budapesti Corvinus Egyetem)

Ladó Judit - Lukács János [2013]: Az Európai Unió új irányelve a számvitelről (Számvitel - Adó - Könyvvizsgálat; 55. évfolyam; 10. szám; pp. 462-464)

Lakatos László Péter [2009]: A számvitel szabályozása, és a pénzügyi kimutatások hasznosságának megítélése (Ph.D értekezés, Budapesti Corvinus Egyetem)

Lakatos László Péter [2012]: A számviteli érdekhordozói elméletek evolúciója és a szabályozás (Vezetéstudomány, XLIV. évfolyam, 5. szám; pp. 47-59) 
Lakatos - Kovács - Mohl - Rózsa - Szirmai [2013]: A Nemzetközi Pénzügyi

Beszámolási Standardok elmélete és gyakorlata 2013. (Magyar Könyvvizsgálói Kamara, Budapest)

Lakatos László Péter [2014]: A számvitel szabályozás eltérésének okairól (Vezetéstudomány, XLV. évfolyam, 9. szám; pp. 2-11)

Lamb, M. - Nobes, C. - Roberts, A. [1998]: International variations in the connections between tax and financial reporting (Accounting and Business Research; Vol. 28. No. 3; pp. 173-188.)

László Norbert [2013]: Vállalkozások pénzügyi helyzetének bemutatása a számviteli beszámolókban a Magyarországon alkalmazott gyakorlat tükrében (Számvitel, Adó, Könyvvizsgálat; 55. évfolyam, 3. szám, 2013. március; p. 141.)

László Norbert [2014]: Cash Flow kimutatások a számviteli beszámolókban (Ph.D. értekezés, Budapesti Corvinus Egyetem)

Lukács János [2008]: Könyvvizsgálati tapasztalatok egy felmérés tükrében: Keresztmetszet a hazai helyzetről. (Számvitel - Adó - Könyvvizsgálat; 50. évfolyam, 11. szám, 2008. november; pp. 466-474.)

Lukács János [2015]: A kkv-k könyvvizsgálati sajátosságai IN: Bod Péter Ákos Freisleben Enikő - Heinczinger Róbert - Juhász Márta - Lukács János - Nátrán Roland - Pádár Péter - Szabó Antal: A kis- és középvállalkozások adózási, számviteli kérdései (Penta Unió Zrt, Budapest)

Madarasiné Dr. Szirmai Andrea [2013]: IFRS SME - IFRS standard a kis- és középvállalkozásokra (Számviteli Tanácsadó; 5. évfolyam, 1. szám; pp. 15-19.)

Majoros György [2010]: A magyar számviteli rendszer értékelése a vezetői számvitel beszámolási rendszerének továbbfejlesztésével (Ph.D értékezés, Szent István Egyetem)

Nagy Gábor [2008]: A számviteli szabályozás elmúlt 50 éve (Számvitel - Adó Könyvvizsgálat; 50. évfolyam, Jubileumi melléklet; pp. 6-8.)

Nagy Gábor [2016a]: 25 éve fogadták el a számviteli törvényt I. Az első gondolatok (Számvitel - Adó - Könyvvizsgálat; 58. évfolyam, 5. szám, pp. 231-233.) 
Nagy Gábor [2016b]: 25 éve fogadták el a számviteli törvényt II. (Számvitel - Adó Könyvvizsgálat; 58. évfolyam, 6. szám, pp. 231-233.)

Nagy László Nándor [2016a]: Adminisztrációs (adó)tehercsökkenés jön (Számvitel Adó - Könyvvizsgálat; 58. évfolyam, 10. szám, pp. 486-487.)

Nagy László Nándor [2016b]: Így segíti a számvitel a versenyképességet (Számvitel Adó - Könyvvizsgálat; 58. évfolyam, 11. szám, p 541.)

NAV [2011]: A NAV Világa évkönyv 2010, Tények, információk a Nemzeti Adó- és Vámhivatal szervezetéről és annak 2010. évi tevékenységéről (Budapest, 2011)

NAV [2012-2017]: NAV évkönyv 2011-2016, Tények, információk a Nemzeti Adó- és Vámhivatal szervezetéről és annak 2011.-2016. évi tevékenységéről (Budapest, 20122017)

Nobes, C. - Schwencke, H. R. [2006]: Modelling the links between tax and financial reporting: a longitudinal examination of Norway over 30 years up to IFRS Adoption (European Accounting Review; Vol. 15. , No. 1., pp. 63-87.)

Nobes, C. - Parker, R. [2008]: Comparative international accounting (Tenth edition, FT/Prentice Hall, Harlow)

Nobes, C. [2010]: On researcing into the Use of IFRS by Private Entities in Europe (Accounting in Europe; Vol. 7., No. 2.; pp. 213-226.)

Nobes, C. [2011]: IFRS practices and the persistence of accounting system classification (Abacus; Vol. 47. No. 3., pp. 267-283.)

Pacter, P. - Scott, D. [2012]: The IFRS for SMEs (IFRS Conference, Dubai, 13 September 2012)

(http://www.ifrs.org/IFRS-for-SMEs/Documents/1209SMEsDubai.pdf Letöltés ideje: 2013. március 12.

Pietra, R. - Evans, L. - Chevy, J. - Cisi, M. - Eierle, B. - Jarvis, R. [2008]: Comment ont he IASB's Exposure Dradt 'IFRS for Small and Medium - sized Entities' (Accounting in Europe; Vol. 5., No.1.; pp. 27-47.)

Quagli, A. - Paoloni, P. [2012]: How is the IFRS for SME Accepted in the European Context? An Analysis of the Homogneity Among European Countries, Users and 
Preparers in the EuropeanCommission Questionaire (Advances in Accounting, incorporating Advances in International Accounting 28(1), pp. 147-156)

Radebaugh, 1. H. - Gray, S. J. - Black, E. L. [2006]: International accounting and multinational enterprises (Sixth edition, John Wiley and Sons, Hoboken)

Reszkető - Váradi [2010]: A vállalkozásokat érintő adminisztratív terhek, versenypolitikai következmények

(http://www.gvh.hu/domain2/files/modules/module25/17884022FA91BD48B.pdf

Letöltés ideje: 2011. szeptember 21.)

Riahi-Belkaoui, A. [2000]: Accounting theory (Fourth edition, Business Press/Thomson Learning, London)

Róth - Adorján - Lukács - Veit [2015]: Pénzügyi számvitel (MKVKOK, Budapest)

Róth - Adorján - Lukács - Veit [2015]: Számviteli esettanulmányok (MKVKOK, Budapest)

Sajtos László - Mitev Ariel [2007]: SPSS kutatási és adatelemzési kézikönyv (Alinea Kiadó, Budapest)

Schablik Béla [2011]: Mit mutatnak az egyszerüsített vállalkozói adó szerint adózók bevallásai? (Számvitel - Adó - Könyvvizsgálat; 53. évfolyam, 1. szám, 2011. január; pp. 18-22.)

Schroeder, R. J. - Clark, M. W. - Cathey, J. M. [2009]: Financial Accounting Theory and Analysis (9th edition; John Wiley and Sons, Hoboken)

Sipos Petra [2010]: A tagállamok IAS/IFRS-alkalmazásának gyakorlata 2010-ben. (Számvitel - Adó - Könyvvizsgálat; 52. évfolyam, 9. szám, 2010. szeptember; pp. 398399.)

Szabó Tamás [2010]: Kérdések és válaszok a kkv-IFRS-ről (Számvitel - Adó Könyvvizsgálat; 52. évfolyam, 7-8. szám; pp. 325-328.)

Szabó Tamás [2011]: Mikrogazdálkodók pénzügyi beszámolásának egyszerüsítése (Számvitel - Adó - Könyvvizsgálat; 53. évfolyam, 4. szám; p. 163.)

Szabó Tamás [2013]: Pénzügyi és egyéb beszámolási reformok az EU-ban (Számvitel Adó - Könyvvizsgálat; 55. évfolyam, 7-8. szám; pp. 348-350.) 
Székács Katalin [2016]: A számviteli rendszerek különbözősége és a számviteli rendszerek osztályozása (BCE Nemzetközi számvitel előadás; Budapest; 2016. szeptember 8.)

Tóth Árpád [2010]: A nemzetközi számviteli standardok lehetséges hatásai a magyarországi kis- és középvállalkozások szabályozására (V. KHEOPS Tudományos konferencia elöadáskötet pp. 5-15.)

Tóth Mihály [2013]: A mikrogazdálkodói beszámoló (Számviteli Tanácsadó; 5. évfolyam, 1. szám; pp. 2-11.)

Walton, P. - Aerts, W. [2006] Global financial accounting and reporting - Princeples and analysis (Thomson Learning, London)

Wolk, H. I. - Dodd, J. 1. - Rozícki, J. J. [2008]: Accounting Theory - Conceptual issues in a political and economic environment (Seventh edition, Sage Publications, London)

Zeff, S. A [2012]: The evolution of the IASC into the IASB, and the challenges it faces (The Accounting Review; Vol. 87., No.3., pp. 807-837.)

Ziebart, D. A. [2002]: An introduction to applied professional research for accountants (Second edition, Prentice Hall; New Jersey) 


\section{Fontosabb jogszabályok:}

2000. évi C. törvény a számvitelről

1996. évi LXXXI. évi törvény a társasági adóról

2013/34/EU irányelv, a meghatározott típusú vállalkozások éves pénzügyi kimutatásairól, összevont (konszolidált) éves pénzügyi kimutatásairól és a kapcsolódó beszámolókról

(http://eur-lex.europa.eu/legal-

content/HU/TXT/HTML/?uri=CELEX:32013L0034\&from=HU)

International Financial Reporting Standard for Small and Medium-sized Entities (IFRS for SMEs)

\section{Honlapok:}

www.e-beszamolo.kim.gov.hu

Www.iasplus.com

www.kormany.hu/hu/nemzetgazdasagi-miniszterium

www.nav.gov.hu 


\section{MELLÉKLETEK}

\section{1. melléklet: Kisebb vállalkozások adatbázisa}

Betéti társaságok

\begin{tabular}{|c|c|c|c|}
\hline \#1 & $\# 2$ & $\begin{array}{c}\text { Cég } \\
\text { sorszám }\end{array}$ & Minősítés \\
\hline 1 & 1 & 92222 & rendben \\
\hline 2 & - & 132145 & nincs beszámoló \\
\hline 3 & 2 & 12900 & rendben \\
\hline 4 & - & 32777 & nincs beszámoló \\
\hline 5 & 3 & 70395 & rendben \\
\hline 6 & - & 77818 & nincs beszámoló \\
\hline 7 & 4 & 66767 & rendben \\
\hline 8 & 5 & 47935 & rendben \\
\hline 9 & 6 & 31277 & rendben \\
\hline 10 & - & 91455 & ÉB \\
\hline 11 & - & 74209 & nincs beszámoló \\
\hline 12 & - & 72101 & nincs beszámoló \\
\hline 13 & - & 45024 & nincs beszámoló \\
\hline 14 & - & 110033 & nincs beszámoló \\
\hline 15 & 7 & 94332 & rendben \\
\hline 16 & - & 33184 & SEÉB \\
\hline 17 & 8 & 96144 & rendben \\
\hline 18 & 9 & 39773 & rendben \\
\hline 19 & 10 & 51394 & rendben \\
\hline 20 & - & 86111 & nincs beszámoló \\
\hline 21 & - & 94172 & SEÉB \\
\hline 22 & 11 & 54971 & rendben \\
\hline 23 & - & 108946 & SEÉB \\
\hline 24 & - & 70782 & nincs beszámoló \\
\hline 25 & 12 & 119251 & rendben \\
\hline
\end{tabular}

\begin{tabular}{|c|c|c|c|}
\hline$\# 1$ & $\# 2$ & $\begin{array}{c}\text { Cég } \\
\text { sorszám }\end{array}$ & Minősítés \\
\hline 26 & 13 & 41754 & rendben \\
\hline 27 & 14 & 25258 & rendben \\
\hline 28 & 15 & 84372 & rendben \\
\hline 29 & - & 6125 & SEÉB \\
\hline 30 & 16 & 116194 & rendben \\
\hline 31 & 17 & 65239 & rendben \\
\hline 32 & 18 & 94982 & rendben \\
\hline 33 & 19 & 131338 & rendben \\
\hline 34 & - & 7180 & nincs beszámoló \\
\hline 35 & - & 4476 & SEÉB \\
\hline 36 & - & 78201 & nincs beszámoló \\
\hline 37 & - & 108874 & nincs beszámoló \\
\hline 38 & 20 & 17746 & rendben \\
\hline 39 & 21 & 59441 & rendben \\
\hline 40 & 22 & 66436 & rendben \\
\hline 41 & 23 & 121596 & rendben \\
\hline 42 & 24 & 93279 & rendben \\
\hline 43 & 25 & 66999 & rendben \\
\hline 44 & - & 5325 & utolsó beszámoló 2008 \\
\hline 45 & - & 85871 & SEÉB \\
\hline 46 & - & 30986 & utolsó beszámoló 2010 \\
\hline 47 & 26 & 135342 & rendben \\
\hline 48 & - & 29209 & SEÉB \\
\hline 49 & 27 & 593 & rendben \\
\hline
\end{tabular}


Korlátolt felelősségü társaságok

\begin{tabular}{|c|c|c|c|}
\hline$\# 1$ & $\# 2$ & $\begin{array}{c}\text { Cég } \\
\text { sorszám }\end{array}$ & Minősítés \\
\hline 1 & 1 & 17345 & rendben \\
\hline 2 & 2 & 147827 & rendben \\
\hline 3 & - & 29928 & ÉB \\
\hline 4 & 3 & 270888 & rendben \\
\hline 5 & - & 126338 & nincs beszámoló \\
\hline 6 & 4 & 286037 & rendben \\
\hline 7 & - & 115096 & nincs beszámoló \\
\hline 8 & 5 & 303734 & rendben \\
\hline 9 & 6 & 267651 & rendben \\
\hline 10 & 7 & 77009 & rendben \\
\hline 11 & 8 & 39931 & rendben \\
\hline 12 & 9 & 86612 & rendben \\
\hline 13 & 10 & 250828 & rendben \\
\hline 14 & - & 346362 & ÉB \\
\hline 15 & 11 & 11062 & rendben \\
\hline 17 & 13 & 284626 & rendben \\
\hline 18 & & 175505 & alapítás 2012 \\
\hline 19 & - & 325154 & nincs beszámoló \\
\hline 20 & - & 348962 & nincs beszámoló \\
\hline 21 & - & 310892 & alapítás 2012 \\
\hline 22 & 14 & 107160 & rendben \\
\hline 23 & - & 195419 & alapítás 2013 \\
\hline 24 & 15 & 141994 & rendben \\
\hline 25 & - & 99966 & nincs beszámoló \\
\hline 26 & - & 245113 & utolsó beszámoló 2011 \\
\hline 27 & 16 & 263878 & rendben \\
\hline 28 & - & 258991 & nincs beszámoló \\
\hline 29 & 17 & 316278 & rendben \\
\hline 30 & - & 58065 & nincs beszámoló \\
\hline 31 & 18 & 228817 & rendben \\
\hline 33 & - & 261005 & ÉB \\
\hline 34 & 20 & 16477 & rendben \\
\hline 35 & 21 & 35089 & rendben \\
\hline 36 & 22 & 83707 & rendben \\
\hline 37 & 23 & 73778 & rendben \\
\hline 38 & 24 & 360082 & rendben \\
\hline 39 & 25 & 183183 & rendben \\
\hline 40 & 26 & 2065 & rendben \\
\hline 41 & - & 139579 & ÉB \\
\hline 42 & 27 & 37216 & rendben \\
\hline 43 & 28 & 333061 & rendben \\
\hline 44 & 29 & 139690 & rendben \\
\hline 45 & 30 & 210427 & rendben \\
\hline 46 & 31 & 207111 & rendben \\
\hline 47 & 32 & 310916 & rendben \\
\hline 48 & 33 & 193925 & rendben \\
\hline 49 & 34 & 121053 & rendben \\
\hline 50 & 35 & 78453 & rendben \\
\hline 51 & - & 94329 & ÉB \\
\hline
\end{tabular}

\begin{tabular}{|c|c|c|c|}
\hline 52 & - & 171651 & alapítás 2013 \\
\hline 53 & 36 & 167174 & rendben \\
\hline 54 & - & 195385 & alapítás 2012 \\
\hline 55 & 37 & 53716 & rendben \\
\hline 56 & - & 346565 & alapítás 2012 \\
\hline 57 & - & 162417 & alapítás 2012 \\
\hline 58 & - & 237417 & utolsó beszámoló 2011 \\
\hline 59 & - & 289008 & alapítás 2013 \\
\hline 60 & - & 261062 & utolsó beszámoló 2009 \\
\hline 61 & - & 72732 & ÉB \\
\hline 62 & - & 182351 & utolsó beszámoló 2009 \\
\hline 63 & 38 & 129567 & rendben \\
\hline 64 & 39 & 56739 & rendben \\
\hline 65 & 40 & 264267 & rendben \\
\hline 66 & - & 74433 & nincs beszámoló \\
\hline 67 & 41 & 166779 & rendben \\
\hline 68 & - & 43812 & nincs beszámoló \\
\hline 69 & 42 & 345059 & rendben \\
\hline 70 & - & 49788 & nincs beszámoló \\
\hline 71 & 43 & 74046 & rendben \\
\hline 73 & 45 & 241156 & rendben \\
\hline 74 & 46 & 99989 & rendben \\
\hline 75 & 47 & 130015 & rendben \\
\hline 76 & 48 & 225665 & rendben \\
\hline 77 & 49 & 67160 & rendben \\
\hline 78 & 50 & 304416 & rendben \\
\hline 79 & 51 & 123569 & rendben \\
\hline 80 & - & 135231 & nincs beszámoló \\
\hline 81 & 52 & 87085 & rendben \\
\hline 82 & 53 & 18402 & rendben \\
\hline 83 & 54 & 143100 & rendben \\
\hline 84 & 55 & 160486 & rendben \\
\hline 85 & 56 & 221101 & rendben \\
\hline 86 & 57 & 231505 & rendben \\
\hline 87 & - & 200595 & alapítás 2012 \\
\hline 88 & - & 42051 & nincs beszámoló \\
\hline 89 & 58 & 291260 & rendben \\
\hline 90 & 59 & 338635 & rendben \\
\hline 91 & 60 & 79758 & rendben \\
\hline 92 & 61 & 232795 & rendben \\
\hline 93 & 62 & 81452 & rendben \\
\hline 94 & 63 & 313591 & rendben \\
\hline 95 & 64 & 199754 & rendben \\
\hline 96 & 65 & 293915 & rendben \\
\hline 97 & 66 & 348393 & rendben \\
\hline 98 & - & 165727 & alapítás 2012 \\
\hline 99 & 67 & 96815 & rendben \\
\hline 100 & 68 & 259694 & rendben \\
\hline 101 & - & 136700 & alapítás 2013 \\
\hline 102 & - & 135663 & alapítás 2013 \\
\hline
\end{tabular}




\begin{tabular}{|r|r|r|l|}
\hline 103 & 69 & 213299 & rendben \\
\hline 104 & 70 & 20306 & rendben \\
\hline 105 & - & 43876 & nincs beszámoló \\
\hline 106 & 71 & 185672 & rendben \\
\hline
\end{tabular}

\begin{tabular}{|r|r|r|l|}
\hline 107 & 72 & 276029 & rendben \\
\hline 108 & - & 119832 & alapítás 2012 \\
\hline 109 & - & 65481 & nincs beszámoló \\
\hline 110 & 73 & 130353 & rendben \\
\hline
\end{tabular}

\#1: sorszám a teljes listában

\#2: sorszám a mintának megfelelőek listájában

Cég sorszám: a kiválasztott cég $\mathrm{ABC}$ szerinti sorszáma a cégadatbázisban 


\section{2. melléklet: Nagyobb vállalkozások adatbázisa}

\begin{tabular}{|c|c|c|c|}
\hline \#1 & $\# 2$ & $\begin{array}{c}\text { Cég } \\
\text { sorszám }\end{array}$ & Minősítés \\
\hline 1 & 1 & 1080 & rendben \\
\hline 2 & 2 & 4072 & rendben \\
\hline 3 & 3 & 2125 & rendben \\
\hline 4 & - & 1980 & 2012-es alapítás \\
\hline 5 & 4 & 2083 & rendben \\
\hline 6 & - & 4140 & EÉ \\
\hline 7 & - & 850 & EÉ \\
\hline 8 & 5 & 3722 & rendben \\
\hline 9 & - & 1787 & EÉ \\
\hline 10 & - & 3555 & EÉ \\
\hline 11 & - & 3265 & EÉ \\
\hline 12 & 6 & 1528 & rendben \\
\hline 13 & 7 & 108 & rendben \\
\hline 14 & 8 & 3984 & rendben \\
\hline 15 & - & 4381 & utolsó beszámoló 2011 \\
\hline 16 & - & 666 & EÉ \\
\hline 17 & 9 & 540 & rendben \\
\hline 18 & - & 1688 & EÉ \\
\hline 19 & 10 & 3340 & rendben \\
\hline 20 & - & 161 & EÉ \\
\hline 21 & 11 & 3799 & rendben \\
\hline 22 & - & 845 & EÉ \\
\hline 23 & - & 3121 & 2012-es alapítás \\
\hline 24 & - & 1502 & nincs beszámoló \\
\hline 25 & 12 & 1657 & rendben \\
\hline 26 & - & 1592 & Biztosító \\
\hline 27 & 13 & 1295 & rendben \\
\hline
\end{tabular}

\begin{tabular}{|r|r|r|l|}
\hline$\# 1$ & $\# 2$ & $\begin{array}{c}\text { Cég } \\
\text { sorszám }\end{array}$ & \multicolumn{1}{|c|}{ Minősítés } \\
\hline 28 & 14 & 1705 & ÉB - Holding \\
\hline 29 & 15 & 1877 & rendben \\
\hline 30 & - & 4526 & EÉ \\
\hline 31 & - & 2421 & É́ \\
\hline 32 & 16 & 162 & rendben \\
\hline 33 & 17 & 4251 & rendben \\
\hline 34 & - & 2072 & nincs beszámoló \\
\hline 35 & - & 1620 & Zálogház \\
\hline 36 & 18 & 441 & rendben \\
\hline 37 & - & 4476 & EÉ \\
\hline 38 & 19 & 4247 & rendben \\
\hline 39 & 20 & 2502 & rendben \\
\hline 40 & 21 & 296 & rendben \\
\hline 41 & - & 538 & É́ \\
\hline 42 & 22 & 174 & rendben \\
\hline 43 & 23 & 276 & rendben \\
\hline 44 & 24 & 4127 & rendben \\
\hline 45 & - & 2076 & EÉ \\
\hline 46 & 25 & 610 & rendben \\
\hline 47 & 26 & 3431 & rendben \\
\hline 48 & - & 292 & EÉ \\
\hline 49 & - & 784 & EÉ \\
\hline 50 & 27 & 4343 & rendben \\
\hline 51 & 28 & 171 & rendben \\
\hline 52 & 29 & 757 & rendben \\
\hline 53 & - & 2711 & EÉ \\
\hline 54 & 30 & 765 & rendben \\
\hline
\end{tabular}

\#1: sorszám a teljes listában

\#2: sorszám a mintának megfelelőek listájában

Cég sorszám: a kiválasztott cég ABC szerinti sorszáma a cégadatbázisban 


\section{3. melléklet: Kérdốiv}

\section{Kérdöív a}

\section{„KKV-k számviteli beszámolási rendszere” \\ Ph.D kutatás mélyinterjújához}

Tisztelt Hölgyem/Uram!

A segítségét szeretném kérni a Budapesti Corvinus Egyetemen folytatott kutatási program megvalósításához, amely a KKV-k számviteli beszámolási rendszerével foglalkozik. Kérjük, hogy a mélyinterjú előtt töltse ki az alábbi kérdőívet, s küldje azt vissza részemre!

Köszönöm megtisztelö közremüködését!

\section{Számviteli beszámolási rendszer}

Hány darab és milyen típusú beszámoló elkészítésében vett részt az elmúlt két évben?

\begin{tabular}{|l|l|l|}
\hline \multicolumn{1}{|c|}{ Beszámoló típusa } & $\mathbf{2 0 1 2}$ & 2013 \\
\hline Éves beszámoló & & \\
\hline Egyszerúsített éves beszámoló & & \\
\hline Sajátos egyszerüsített éves beszámoló & & \\
\hline Mikrogazdálkodói beszámoló & & \\
\hline Egyéb & & \\
\hline \hline Összesen & & \\
\hline
\end{tabular}

Mi a véleménye a számviteli beszámoltatás rendszerében bekövetkezett egyszerüsítésekről?

Sajátos egyszerüsített éves beszámoló:

Mikrogazdálkodói beszámoló:

Amennyiben használta ezen egyszerüsített beszámolási formákat:

Mikortól?

Áttérés oka?

Ki döntött az áttérésröl?

Tapasztalatok 
Van-e olyan vállalkozás, amely választhatott volna egyszerübb beszámolási formát, de mégsem tette? Amennyiben ismert az indoka, kérjük, röviden írja le!

Milyen mértékü egyszerüsítésnek ítéli meg a Mikrogazdálkodói beszámolót egy tízfokozatú skálán? (10 nagymértékü egyszerüsítés, 1 semmilyen mértékủ egyszerüsítés, 0 bonyolítás)

\section{Számviteli politika}

Hogyan alakítják ki a könyvelt cégek számviteli politikáját?

\begin{tabular}{|l|l|}
\hline \multicolumn{1}{|c|}{ Ki dönt a számviteli politikáról? } & Cégek száma $(\mathbf{d b})$ \\
\hline Cégvezetés önállóan & \\
\hline Könyvelő önállóan & \\
\hline Közösen & \\
\hline Összesen & \\
\hline
\end{tabular}

Milyen megoldásokat választottak a cégek az alábbi számviteli politikai döntések során? Kérjük, az egyes lehetőségeknél a cégek számát írja be a módszer alatti négyzetbe!

\begin{tabular}{|c|c|c|c|}
\hline \multicolumn{4}{|c|}{ Értékcsökkenési leírási módszer } \\
\hline lineáris & más módszer & & $\begin{array}{l}\text { nincs tárgyi eszköz, } \\
\text { immateriális eszközz }\end{array}$ \\
\hline \multicolumn{4}{|c|}{ Értékcsökkenési leírási kulcs } \\
\hline TAO szerinti & TAO-tól eltérö & & $\begin{array}{l}\text { nincs tárgyi eszköz, } \\
\text { immateriális eszköz }\end{array}$ \\
\hline \multicolumn{4}{|c|}{ Értékcsökkenési leírásnál maradványérték alkalmazása } \\
\hline $\begin{array}{l}\text { nincs } \\
\text { maradványérték }\end{array}$ & van maradványérték & & $\begin{array}{l}\text { nincs tárgyi eszköz, } \\
\text { immateriális eszköz }\end{array}$ \\
\hline \multicolumn{4}{|c|}{ Kisértékű tárgyi eszközök egyösszegü leírása } \\
\hline $\begin{array}{l}\text { alkalmazza } \\
(100 \mathrm{eFt})\end{array}$ & $\begin{array}{l}\text { alkalmazza } \\
\text { (más összeg) }\end{array}$ & $\begin{array}{l}\text { nem } \\
\text { alkalmazza }\end{array}$ & $\begin{array}{l}\text { nincs kisértékü tárgyi } \\
\text { eszköz }\end{array}$ \\
\hline
\end{tabular}




\begin{tabular}{|c|c|c|c|}
\hline \multicolumn{4}{|c|}{ Választott devizaárfolyam } \\
\hline MNB & pénzintézeti átlag & egyéb & nincs devizás ügylet \\
\hline \multicolumn{4}{|l|}{ Készlet - nyilvántartás } \\
\hline nem vezet & vezet & & nincs készlet \\
\hline \multicolumn{4}{|l|}{ Készlet - értékelés } \\
\hline FIFO & átlagár & egyéb & nincs készlet \\
\hline \multicolumn{4}{|l|}{ Költségelszámolás } \\
\hline Csak költségnem (5) & Kombinált $(5+6 / 7)$ & & \\
\hline \multicolumn{4}{|c|}{ Eredménykimutatás fajtája } \\
\hline összköltséges & forgalmis & mindkettő & \\
\hline \multicolumn{4}{|c|}{ Alapítás-átszervezés értékének kezelése } \\
\hline költségként számolja el & aktiválja & & $\begin{array}{l}\text { alapítással kapcsolatos } \\
\text { költségeket nem a cégre } \\
\text { számolta el }\end{array}$ \\
\hline \multicolumn{4}{|c|}{ Kísérleti fejlesztés értékének kezelése } \\
\hline költségként számolja el & aktiválja & & nincs kísérleti fejlesztés \\
\hline \multicolumn{4}{|l|}{ Értékhelyesbítés } \\
\hline nem alkalmazza & alkalmazza & & $\begin{array}{l}\text { nincs olyan eszköz } \\
\text { amelyre értékhelyesbítést } \\
\text { lehet alkalmazni }\end{array}$ \\
\hline \multicolumn{4}{|c|}{ Céltartalék képzése a jövőbeli költségekre } \\
\hline nem alkalmazza & alkalmazza & & \\
\hline \multicolumn{4}{|c|}{ Devizás beruházási hitel árfolyamveszteségének elhatárolása } \\
\hline nem alkalmazza & alkalmazza & & $\begin{array}{l}\text { nincs devizás beruházási } \\
\text { hitel }\end{array}$ \\
\hline & & & \\
\hline
\end{tabular}




\begin{tabular}{|l|l|l|l|}
\hline \multicolumn{2}{|l|}{ Valós értékelés } & & $\begin{array}{l}\text { nincs olyan vagyontárgya } \\
\text { (pénzügyi instrumentum) } \\
\text { amelyre alkalmazni } \\
\text { lehetne }\end{array}$ \\
\hline nem alkalmazza & alkalmazza & \\
\hline
\end{tabular}

\section{Számvitel és adózás kapcsolata}

Mennyire tartja az adózási szempontokat meghatározónak a könyvelésnél és a beszámoló készítésénél a cégmérettel összefüggésben egy tízfokozatú skálán értékelve? (1 az adózás egyáltalán nem befolyásolja, 10 csak az adózási szempontok számítanak)

\begin{tabular}{|l|l|}
\hline \multicolumn{1}{|c|}{ Vállalkozás mérete } & Értékelés \\
\hline Mikrogazdálkodó & \\
\hline Kisvállalkozás & \\
\hline Közepes vállalkozás & \\
\hline Nagyvállalkozás & \\
\hline
\end{tabular}

Gondolja végig, hogy milyen további egyszerüsítési lehetőségeket lát a KKV szektor számviteli beszámolásával kapcsolatban!

Van-e egyéb észrevétele, javaslata? 


\section{4. melléklet: Tao bevallás}

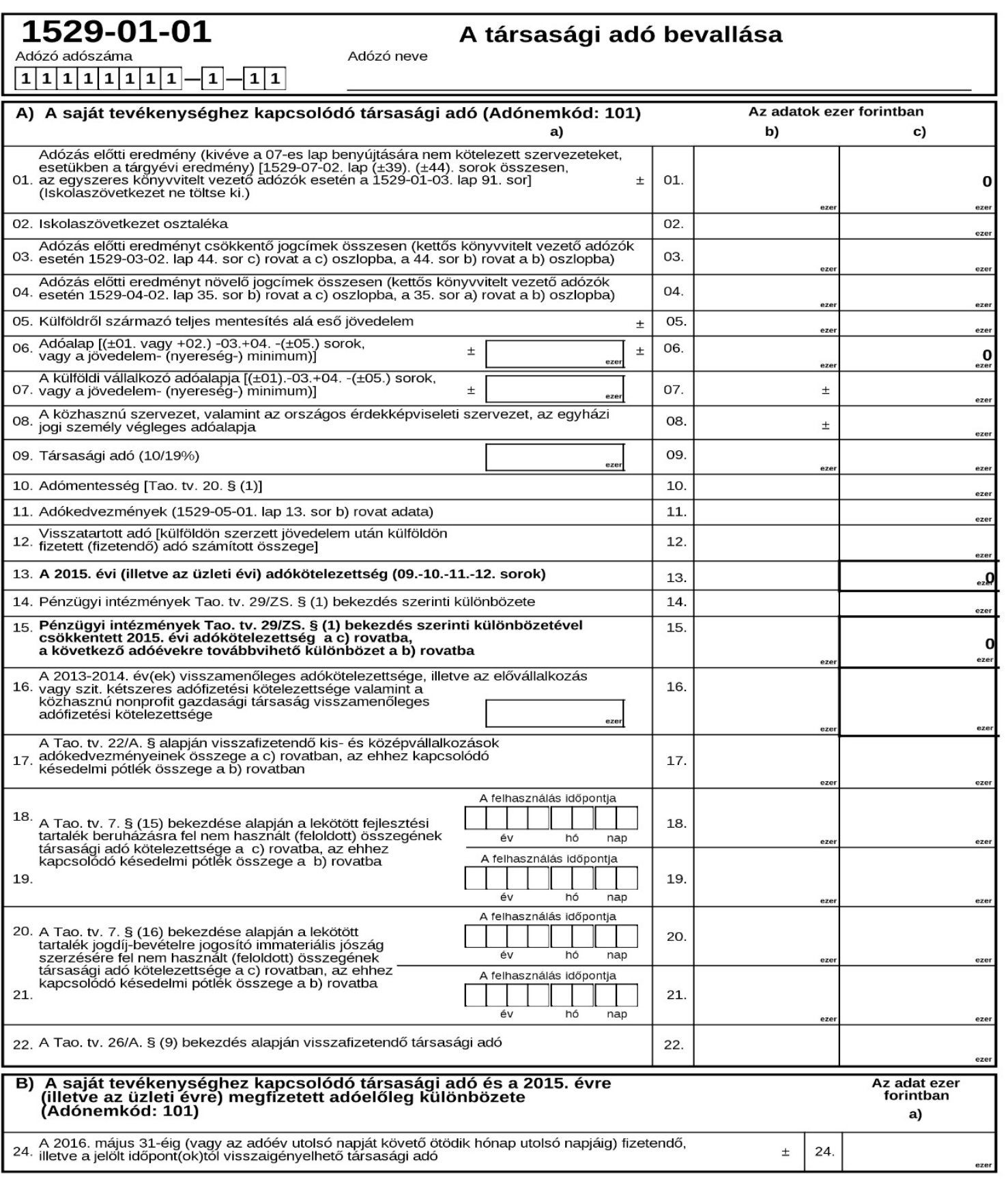




\section{9-03-01}

Adózó adószáma

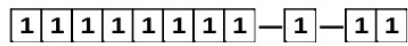

\section{Az adózás elótti eredményt csökkentó jogcímek} Adózó neve

a kettốs könyvvitelt vezetó adózók részére

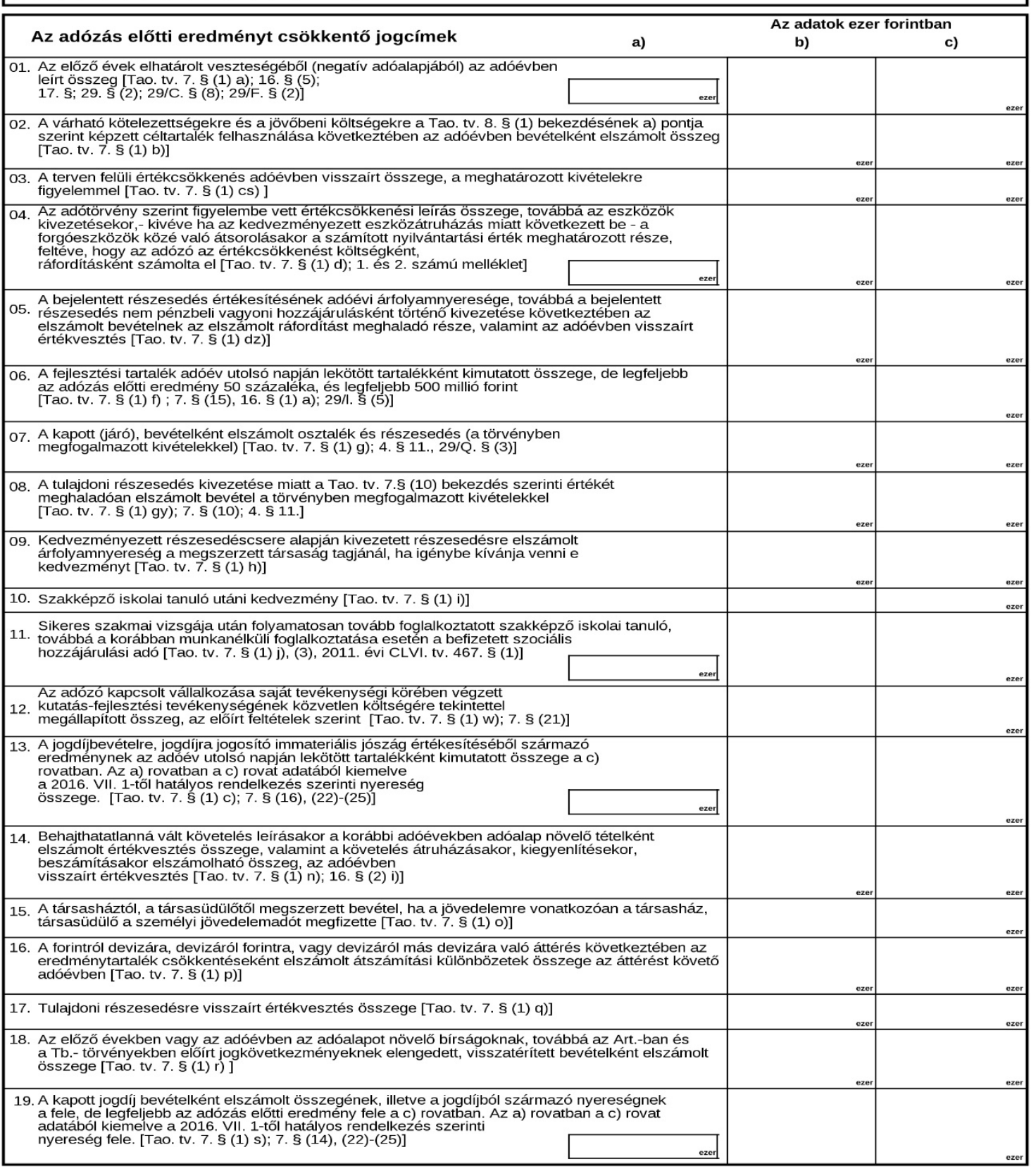




\section{9-03-02}

Adózó adószáma

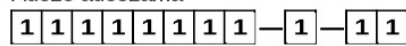

\section{Az adózás elótti eredményt csökkentó jogcímek a kettós könyvvitelt vezetó adózók részére}

\begin{tabular}{|c|c|c|}
\hline \multirow{2}{*}{$\begin{array}{l}\text { Az adózás elótti eredményt csökkentő jogcímek (folytatás) } \\
\text { 20. Az alapkutatás, az alkalmazott kutatás és a kísérleti fejlesztés adóévben felmerült közvetlen } \\
\text { költségeként elszámolt, a kapott támogatással az elöirt feltételek szerint csökkentett összege } \\
{[\text { Tao. tv. } 7 . \S(1) \text { t); } 7 . \S(17),(18), 29 / G . \$(2)]}\end{array}$} & \multicolumn{2}{|c|}{$\begin{array}{l}\text { Az adatok ezer forintban } \\
\text { b) }\end{array}$} \\
\hline & & \\
\hline 21. Múemlék értékét növelő felújítás költsége [Tao. tv. 7. § (1) ty)] & ezer & eze \\
\hline $\begin{array}{l}\text { 22. Az adóellenốrzés, önellenốrzés során megállapított adóévi bevételként, vagy aktivált } \\
\text { saját teljesítmény növeléseként, vagy adóévi költség, ráfordítás csökkenéseként } \\
\text { elszámolt összeg [Tao. tv. 7. § (1) u)] }\end{array}$ & ezer & \\
\hline $\begin{array}{l}\text { 23. Megváltozott munkaképességú munkavállaló foglalkoztatása esetén személyenként, } \\
\text { havonta a megváltozott munkaképességú részére kifizetett munkabér, de legfeljebb } \\
\text { az adóév elsón napján érvényes minimaálbér, ha az adózó altal foglalkoztatottak âtlagos } \\
\text { állományi létszáma nem haladja meg a } 20 \text { fôt [Tao. tv. } 7 \text {. \$ (1) v)] }\end{array}$ & & \\
\hline 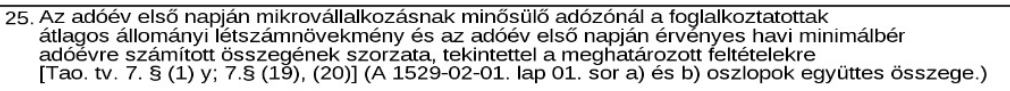 & & \\
\hline $\begin{array}{l}\text { 26. Támogatás, juttatás meghatározott összege } \\
\text { [Tao. tv. 7. § (1) z); (7); 29/C. § (7)] }\end{array}$ & & \\
\hline 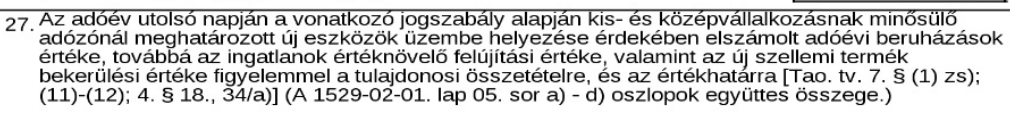 & & \\
\hline $\begin{array}{l}\text { 28. A külföldi pénzértékben fennálló egyes követelések és kötelezettségek értékelésekor } \\
\text { megálapított, nyereséget eredménnyezö, nem realizált árfolyamkülönbözet az adózó döntése } \\
\text { szerint [Tao. tv. } 7 . \text { \$ (1) dzs); (2)] }\end{array}$ & ezer & ezerer \\
\hline 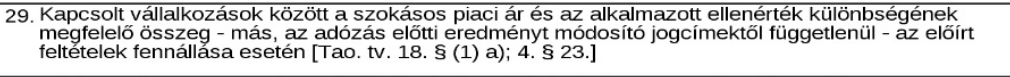 & & \\
\hline $\begin{array}{l}\text { 30. Közhasznú szervezetnek minósüló alapítvány, közalapítvány, egyesület, köztestület, } \\
\text { felsốoktatási intézmény az európai területi társulás vállalkozási } \\
\text { tevékenysége adózás elốtti nyereségének } 20 \text { százaléka [Tao. tv. 9. § (2) b)] }\end{array}$ & & \\
\hline $\begin{array}{l}\text { 31. Munkáltatói és munkavállalói érdekképviseleti szervezet vállalkozási nyereségének az a } \\
\text { része, melyet a cél szerinti tevékenység bevételeit meghaladó költségei, } \\
\text { ráfordításai fedezetére felhasznált az adóévben, illetve } \\
\text { az a) rovatban továbbvitt rész [Tao. tv. } 9 . \text { (2) e); 4. \$ 25.] }\end{array}$ & & \\
\hline $\begin{array}{l}\text { 32. Az egyházi jogi személy vállalkozási tevékenységébỏl elért nyereségének } \\
\text { meghatározott költségek, ráfordítások fedezetére felhasznált, illetve e célból lekötött } \\
\text { tartalékba helyezett ôsszeg [Tao. tv. 9. \$ (5)] }\end{array}$ & & \\
\hline $\begin{array}{l}\text { 33. A külföldi vállalkozó belföldi telephelyére arányosan jutó üzletvezetési és általános } \\
\text { ügyviteli költségei, ráforditásai [Tao. tv. } 14 . \text { S (2) a)] }\end{array}$ & & \\
\hline $\begin{array}{l}\text { 34. Jogelődnél kiválás esetén a jogutódnál elsó adóévében a nem kedvezményezett } \\
\text { átalakuláskoor, és kedvezmenyezett átalakulásnál az adózó választása szerint a } \\
\text { Tao. tv. 16. § (2) d) pontja szerinti összeg }\end{array}$ & & \\
\hline $\begin{array}{l}\text { 35. A jogutódnál kedvezményezett átalakulás miatt fennáló Tao. tv. 16. § (11) bek. szerinti } \\
\text { csökkentốtétel összege }\end{array}$ & ezer & \\
\hline $\begin{array}{l}\text { 36. Kedvezményezett eszközátruházás esetén az átruházó társaságnál - választása szerint -e } \\
\text { jogügylet alapján elszámolt bevételnek az átadott eszközö̌k egyưttes könyv szerinti értékét } \\
\text { meghaladó része [Tao. tv. 16. \$ (12)-(14)] }\end{array}$ & & \\
\hline $\begin{array}{l}\text { 37. Kedvezményezett eszközátruházáshoz kapcsolódó tétel az átvevố társaságnál } \\
\text { [Tao. tv. 16. \$ (13)-(14)] }\end{array}$ & ezer & \\
\hline $\begin{array}{l}\text { 38. A bejelentett immateriális jószág értékesítésének pozítív nyeresége a c) rovatban. Az a) rovatban } \\
\text { a c) rovat adatából kiemelve a 2016. VII. 1-tól hatályos rendelkezés } \\
\text { szerinti nyereség összege. [Tao. tv. } 7 . \S(1) \text { e); (22)-(25)] }\end{array}$ & & \\
\hline $\begin{array}{l}\text { 39. MÁV Zrt-tôll és a MÁV-START Zrt-tốl átvállalt, vagy elengedett kötelezettségbôl adódó } \\
\text { bevétel összege [Tao. tv. 29/A. § (3)] }\end{array}$ & & \\
\hline 40. Pénzügyi intézmény kapott támogatásra tekintettel elszámolt bevétele [Tao. tv. 29/ZS. § (7b)] & & \\
\hline $\begin{array}{l}\text { A Budapesti Közlekedési Zrt-nek a Magyar Állam részéról átvállalt vagy } \\
\text { 41. elengedett kötelezettség elszámolásábol származó bevétele [29/A. S (12)] }\end{array}$ & & \\
\hline $\begin{array}{l}\text { 42. Egyéb csökkentố jogcímek [Az a) rovatban a c) rovat összegéból kiemelve a } \\
\text { Tao. tv. 29/D. \& (9) szerinti, vállalkozási övezetben üzembe helyezett } \\
\text { épület, építmény bekerülési értékének adóévi } 10 \text { százaléka] }\end{array}$ & & \\
\hline 43. & & \\
\hline 44. Összesen [01- 42. sorok; egyezóen a 1529-01-01. lap 03. sor b) és/vagy c) rovatával] & & \\
\hline
\end{tabular}




\section{9-04-01}

Adózó adószáma \begin{tabular}{|l|l|l|l|l|l|l|l|l|l|l|l|}
\hline $\mathbf{1}$ & $\mathbf{1}$ & $\mathbf{1}$ & $\mathbf{1}$ & $\mathbf{1}$ & $\mathbf{1}$ & $\mathbf{1}$ & $\mathbf{1}$ \\
\hline
\end{tabular}

\section{Az adózás elótti eredményt növeló jogcímek}

a kettôs könyvvitelt vezetó adózók rẻszére Adózó neve

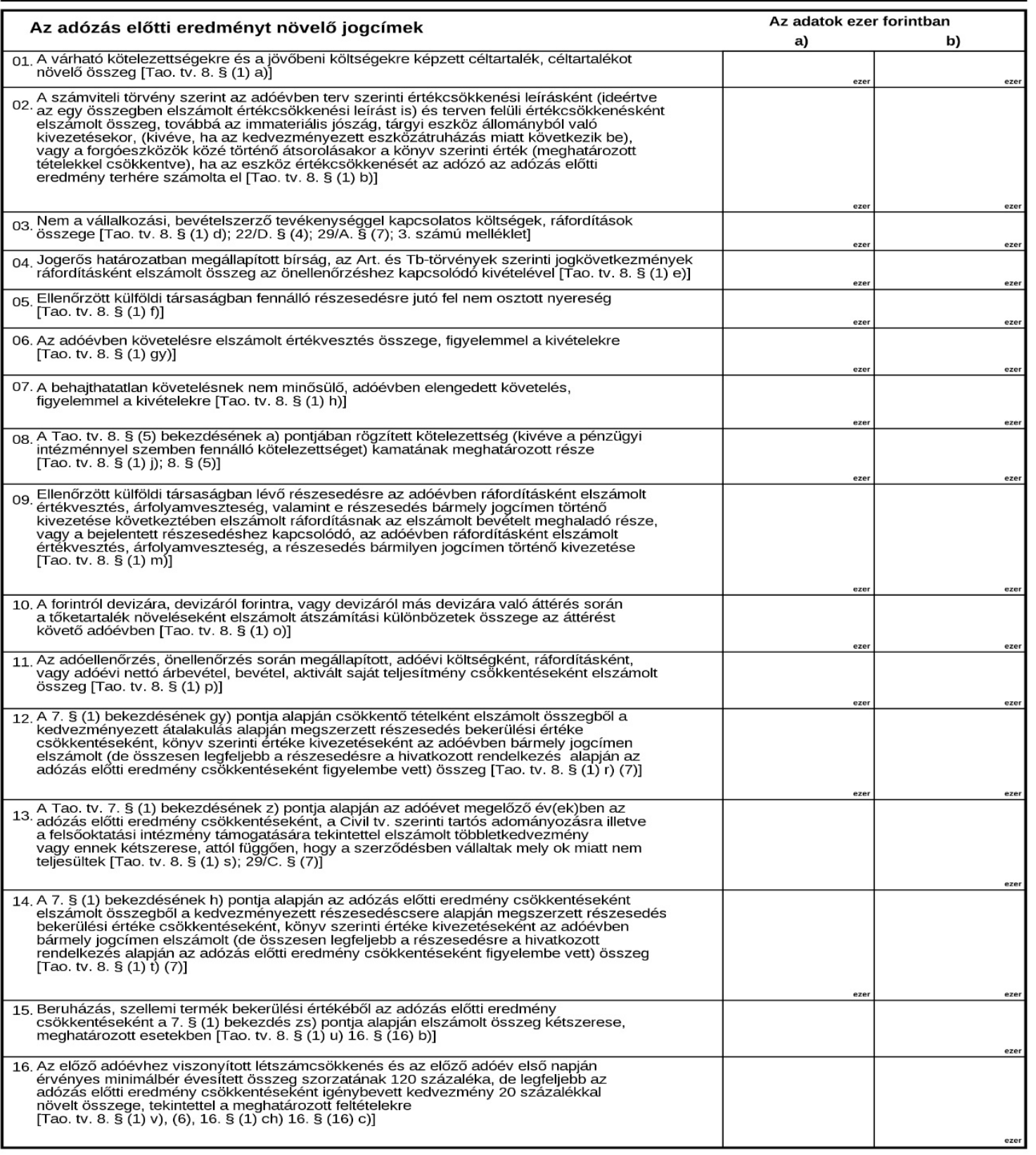




\section{9-04-02}

Adózó adószáma

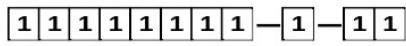

\section{Az adózás elótti eredményt növeló jogcímek a kettős könyvvitelt vezetó adózók részére}

Adózó neve

Az adózás elốtti eredményt növelố jogcímek (folytatás)

Az adatok ezer forintban

a)

b)

\begin{tabular}{|c|c|c|}
\hline $\begin{array}{l}\text { 17. A külföldi pénzértékben fennálló egyes követelések és kötelezettségek értékelésekor } \\
\text { megállapított, nem realizált veszteség jellegú árfolyamkülönbözet [Tao. tv. 8. § (1) dzs); } 7 \text {. § (2)] }\end{array}$ & ezer & ezer \\
\hline 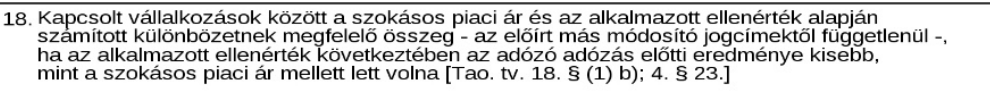 & ezer & ezer \\
\hline 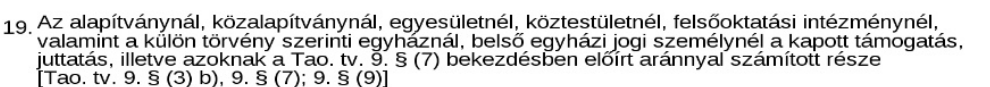 & & \\
\hline $\begin{array}{l}\text { 20. Adómentesen képzôdött eredménytartalék összege az iskolaszövetkezetnél, illetve } \\
\text { a jogutódjánál, ha a jogutód nem iskolaszövetkezet [Tao. tv. 10. \$ (1), (4)-(5),] }\end{array}$ & & 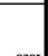 \\
\hline $\begin{array}{l}\text { 21. A közhasznú nonprofit gazdasági társaság tagjának a tagsági viszony megszünésekor, } \\
\text { vagy a jegyzett tôke leszállításakor a tag részére kiadott sajăt tôkének a Tao. tv. 13/A.\$ (3) } \\
\text { bekezdésben meghatározott értéke [Tao. tv. 13/A.\$ (2) a)] }\end{array}$ & & ezer \\
\hline $\begin{array}{l}\text { A közhasznú nonprofit gazdasági társaságok egyesülése, szétválása } \\
\text { 22. esetén a jogutódnál a jogszabály szerinti ôsszeg [Tao. tv. 13/A. \$ (5) (2) b)] }\end{array}$ & & \\
\hline $\begin{array}{l}\text { 23. A közhasznú nonprofit gazdasági társaságnál, szociális szövetkezetnél - adóév utolsó } \\
\text { napján az állami vagy onkoormányzati adóhatóságnál nyilvántartott adótartozása esetén } \\
\text { - a kapott támogatás, juttatás összege [Tao. tv. 13/A. \$ (2) d] }\end{array}$ & & 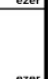 \\
\hline $\begin{array}{l}\text { 24. A küllöldi vállalkozó belföldi telephelyénél az adóévi adózás elōtti eredmény terhére elszámolt } \\
\text { valamennyi üzletvezetési és általános ügyviteli költség, ráfordítás [Tao. tv. 14. § (2) b)] }\end{array}$ & & ezer \\
\hline $\begin{array}{l}\text { 25. A külföldi vállalkozó belföldi telephelyénél a telephely közvetítésével elért, de a telephelynél } \\
\text { közvetlenül el nem számolt árbevétel, bevétel } 5 \text { százaléka [Tao. tv. 14. \$ (2) C)] }\end{array}$ & & \\
\hline $\begin{array}{l}\text { 26. A jogelódnél, kiválás esetén a jogutódnál elsố adóévben a nem kedvezményezett } \\
\text { átalakuláskor, és kedvezményezett átalakulásnál az adózó választása szerint } \\
\text { Tao tv. } 16 . \$(2) \text { bek. d) pontja szerinti összeg }\end{array}$ & ezer & ezer \\
\hline $\begin{array}{l}\text { 27. A jogutódnál a kedvezményezett átalakulás miatt fennáló Tao. tv. 16. § (11) bek. szerinti } \\
\text { nôvelố tétel összege }\end{array}$ & ezer & ezer \\
\hline $\begin{array}{l}\text { 28. Kedvezményezett eszközátruházás esetén az átruházó társaságnál az átadott eszközök } \\
\text { könyv szerinti értékének az elszámolt bevétellel csökkentett összege [Tao. tv. 16. § (12)-(14)] }\end{array}$ & ezer & ezer \\
\hline $\begin{array}{l}\text { 29. Kedvezményezett eszközátruházáshoz kapcsolódó tétel az átvevő társaságnál } \\
\text { [Tao. tv. 16. § (13)-(14)] }\end{array}$ & ezer & ezer \\
\hline 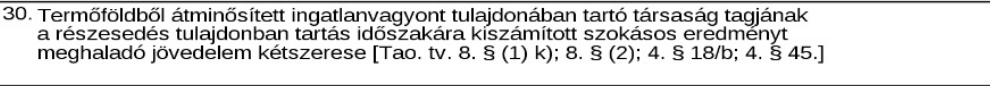 & ezer & ezer \\
\hline $\begin{array}{l}\text { 31. Termôföldbốl átminősített ingatlan tulajdonban tartásának idốszakára } \\
\text { kiszámított szokásos eredményt meghaladó jövedelem kétszerese } \\
\text { [Tao. tv. 8. \$ (1) I; 8. \$ (2);4. \$18/c; 4. \$ 45.] }\end{array}$ & ezer & ezer \\
\hline $\begin{array}{l}\text { A bejelentett immateriális jószág bármely jogcímen történő kivezetésének a } \\
\text { 32. meghatározott arányszámmal megállapitott vesztesége [Tao. tv. 8. § (1) n)] }\end{array}$ & & ezer \\
\hline 33. Egyéb növelö jogcímek & ezer & ezer \\
\hline 34. & & \\
\hline 35. Összesen [01-33. sorok; egyezően a 1529-01-01. lap 04. sor b) és/vagy c) rovatával] & ezer & ezer \\
\hline
\end{tabular}




\section{5. melléklet: H1-hez alapstatisztikák}

Case Processing Summary

\begin{tabular}{|c|c|c|c|c|c|c|c|}
\hline & \multirow{3}{*}{$\begin{array}{l}\text { Beszámoló } \\
\text { típusa }\end{array}$} & \multicolumn{6}{|c|}{ Cases } \\
\hline & & \multicolumn{2}{|c|}{ Valid } & \multicolumn{2}{|c|}{ Missing } & \multicolumn{2}{|c|}{ Total } \\
\hline & & $\mathrm{N}$ & Percent & \begin{tabular}{|l|}
$\mathrm{N}$ \\
\end{tabular} & Percent & \begin{tabular}{l|l}
$\mathrm{N}$ & \\
\end{tabular} & Percent \\
\hline \multirow{5}{*}{ Á1 } & EÉ (Bt.) & 27 & $100,0 \%$ & 0 & $0,0 \%$ & 27 & $100,0 \%$ \\
\hline & EÉ (Kft.) & 73 & $100,0 \%$ & 0 & $0,0 \%$ & 73 & $100,0 \%$ \\
\hline & EÉ (Bt.+Kft.) & 100 & $100,0 \%$ & 0 & $0,0 \%$ & 100 & $100,0 \%$ \\
\hline & ÉB (Rt.) & 30 & $100,0 \%$ & 0 & $0,0 \%$ & 30 & $100,0 \%$ \\
\hline & Össz. & 130 & $100,0 \%$ & 0 & $0,0 \%$ & 130 & $100,0 \%$ \\
\hline
\end{tabular}

Tests of Normality

\begin{tabular}{|l|r|r|r|r|r|r|}
\hline \multirow{2}{*}{$\begin{array}{l}\text { Beszámoló } \\
\text { típusa }\end{array}$} & \multicolumn{3}{|c|}{ Kolmogorov-Smirnov $^{\mathrm{a}}$} & \multicolumn{3}{c|}{ Shapiro-Wilk } \\
\cline { 2 - 7 } & Statistic & \multicolumn{1}{c|}{ df } & \multicolumn{1}{c|}{ Sig. } & Statistic & df & \multicolumn{1}{c|}{ Sig. } \\
\hline \multirow{4}{*}{ EÉ (Bt.) } &, 301 & 27 &, 000 &, 788 & 27 &, 000 \\
EÉ (Kft.) &, 363 & 73 &, 000 &, 696 & 73 &, 000 \\
Á1 &, 348 & 100 &, 000 &, 724 & 100 &, 000 \\
EÉ (Bt.+Kft.) &, 161 & 30 &, 047 &, 903 & 30 &, 010 \\
ÉB (Rt.) &, 285 & 130 &, 000 &, 797 & 130 &, 000 \\
Össz. & \multicolumn{4}{c}{}
\end{tabular}

a. Lilliefors Significance Correction

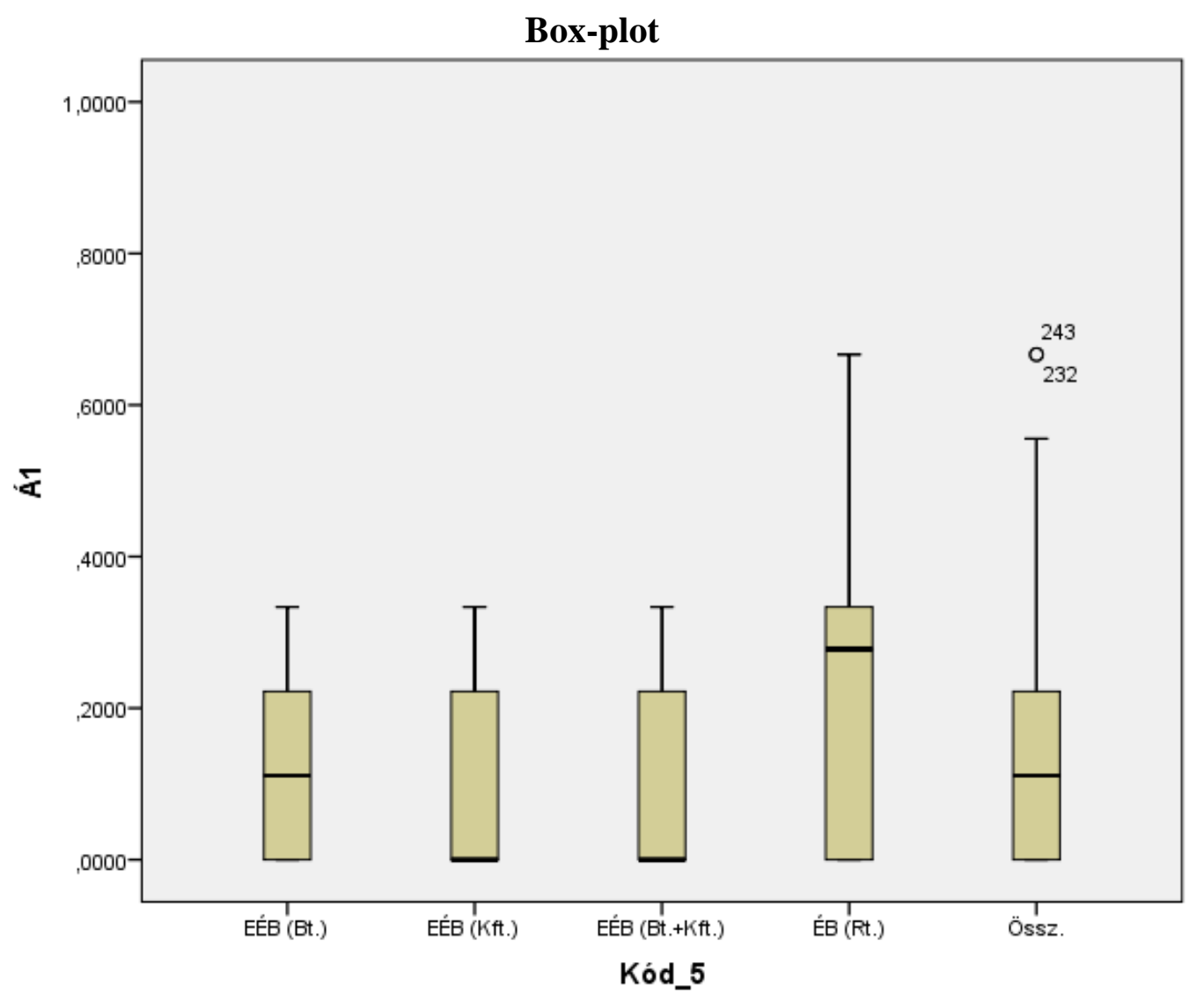



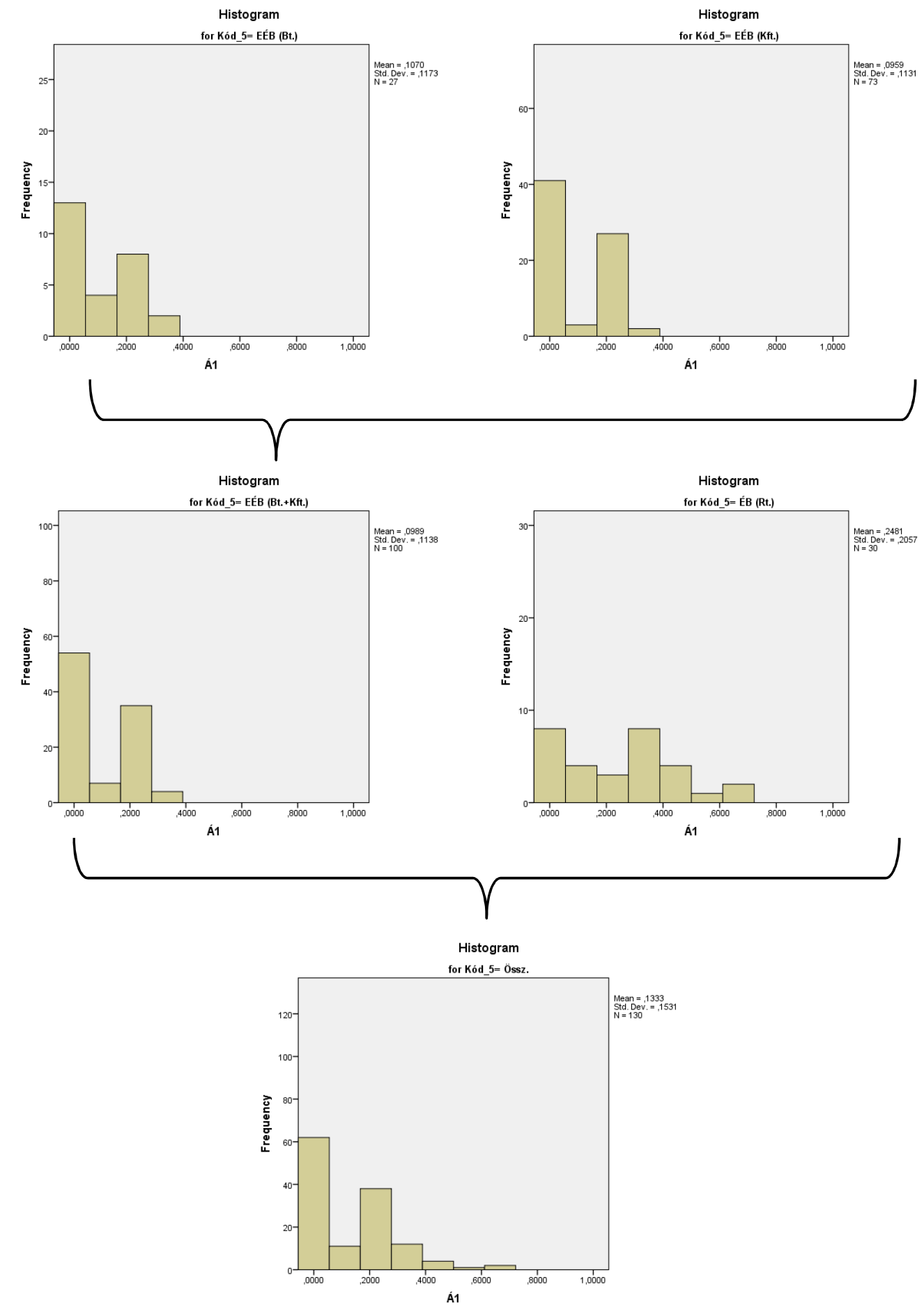
Normal Q-Q + Detrended Normal Q-Q
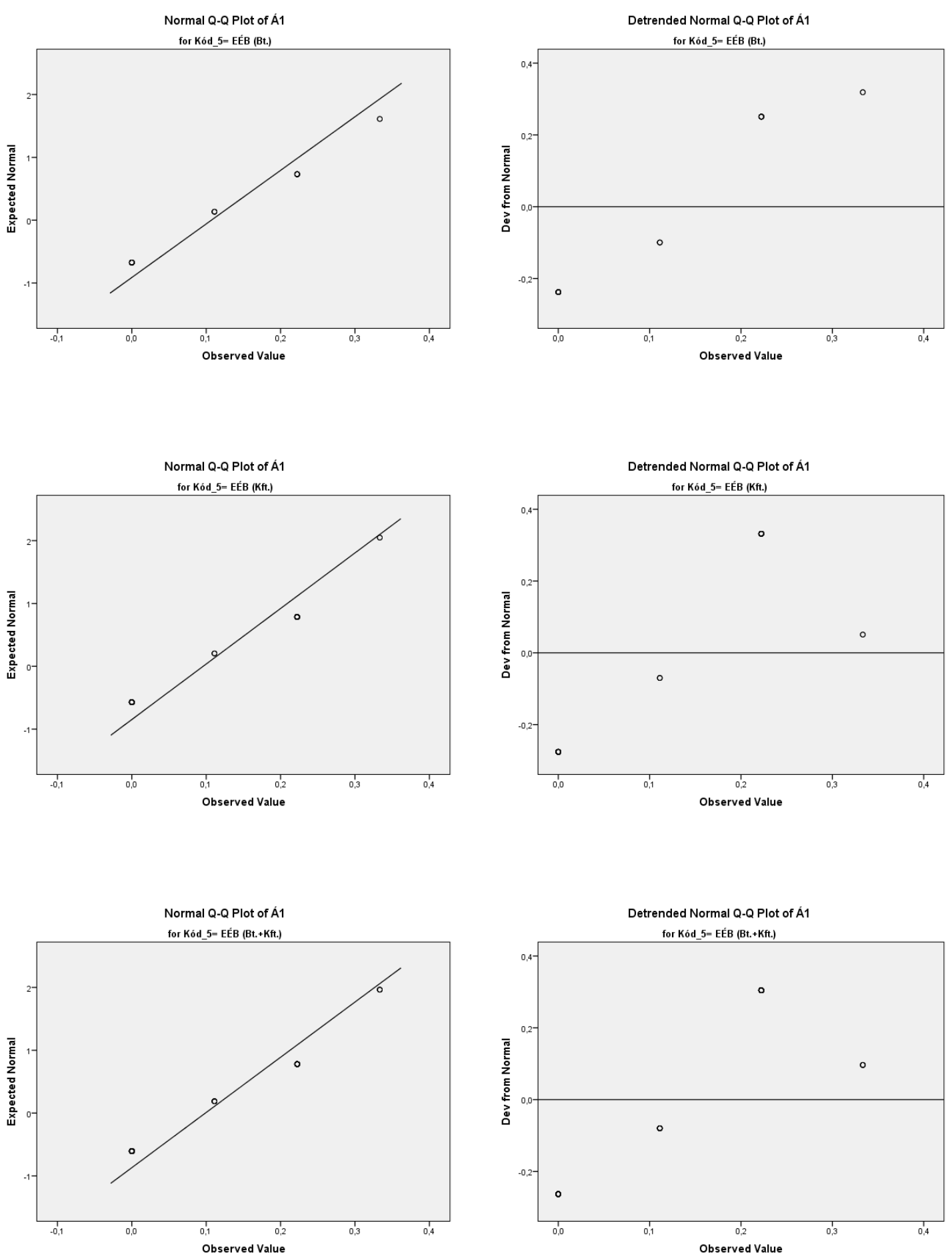

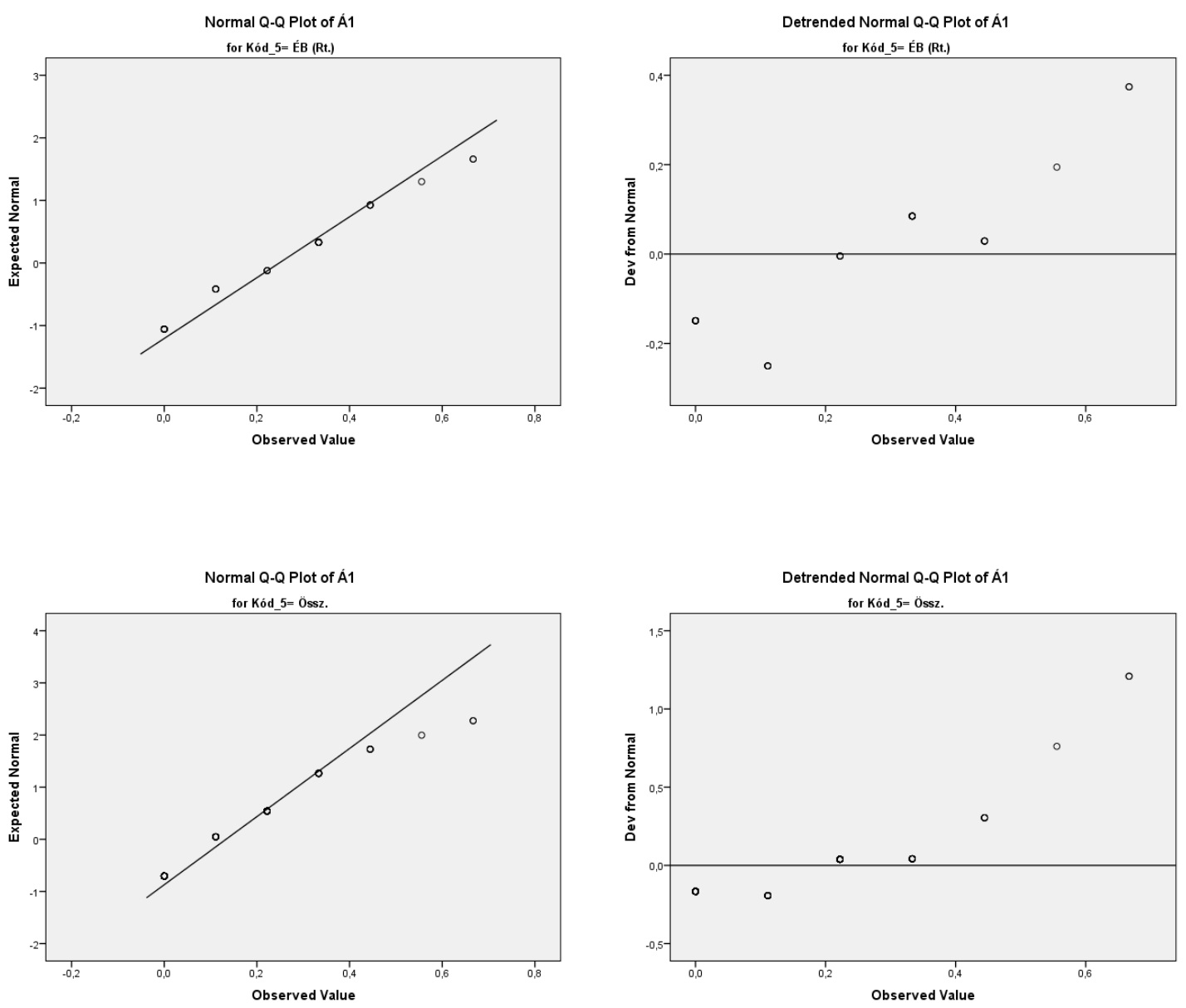


\section{6. melléklet: H1-hez varianciaanalízis}

\begin{tabular}{|c|c|c|c|c|c|c|c|c|}
\hline \multicolumn{9}{|c|}{ Descriptives } \\
\hline \multirow{2}{*}{ Á1 } & \multirow{2}{*}{$\mathrm{N}$} & \multirow{2}{*}{ Mean } & \multirow{2}{*}{$\begin{array}{c}\text { Std. } \\
\text { Deviation }\end{array}$} & \multirow{2}{*}{$\begin{array}{l}\text { Std. } \\
\text { Error }\end{array}$} & \multicolumn{2}{|c|}{ 95\% Confidence Interval for Mean } & \multirow{2}{*}{ Min. } & \multirow{2}{*}{ Max. } \\
\hline & & & & & Lower Bound & Upper Bound & & \\
\hline EÉ (Bt.) & 27 & , 106996 &, 1172715 & ,0225689 & ,060605 &, 153387 &, 0000 & ,3333 \\
\hline EÉ (Kft.) & 73 & ,095890 & ,1131223 & ,0132400 & ,069497 &, 122284 & ,0000 & ,3333 \\
\hline EÉ (Bt.+Kft.) & 100 & ,098889 &, 1137674 & ,0113767 & ,076315 & ,121463 &, 0000 & ,3333 \\
\hline ÉB (Rt.) & 30 & ,248148 & ,2056737 & ,0375507 & , 171348 & ,324948 & ,0000 & ,6667 \\
\hline Össz. & 130 & ,133333 & , 1530623 & 0134245 & , 106773 &, 159894 & ,0000 & ,6667 \\
\hline Total & 360 &, 123765 &, 1436830 & ,0075728 & ,108873 &, 138658 &, 0000 & ,6667 \\
\hline
\end{tabular}

Két kategóriás elemzés: EÉ, ÉB

Test of Homogeneity of Variances

\begin{tabular}{|c|c|c|c|}
\hline Levene Statistic & df1 & $\mathrm{df} 2$ & Sig. \\
\hline 29,162 & 1 & 128 &, 000 \\
\hline
\end{tabular}

ANOVA

\begin{tabular}{|l|r|r|r|r|r|}
\hline \multicolumn{1}{|c|}{ Á1 } & Sum of Squares & df & Mean Square & F & Sig. \\
\hline Between Groups &, 514 & 1 &, 514 & 26,238 &, 000 \\
Within Groups & 2,508 & 128 &, 020 & & \\
Total & 3,022 & 129 & & & \\
\hline
\end{tabular}

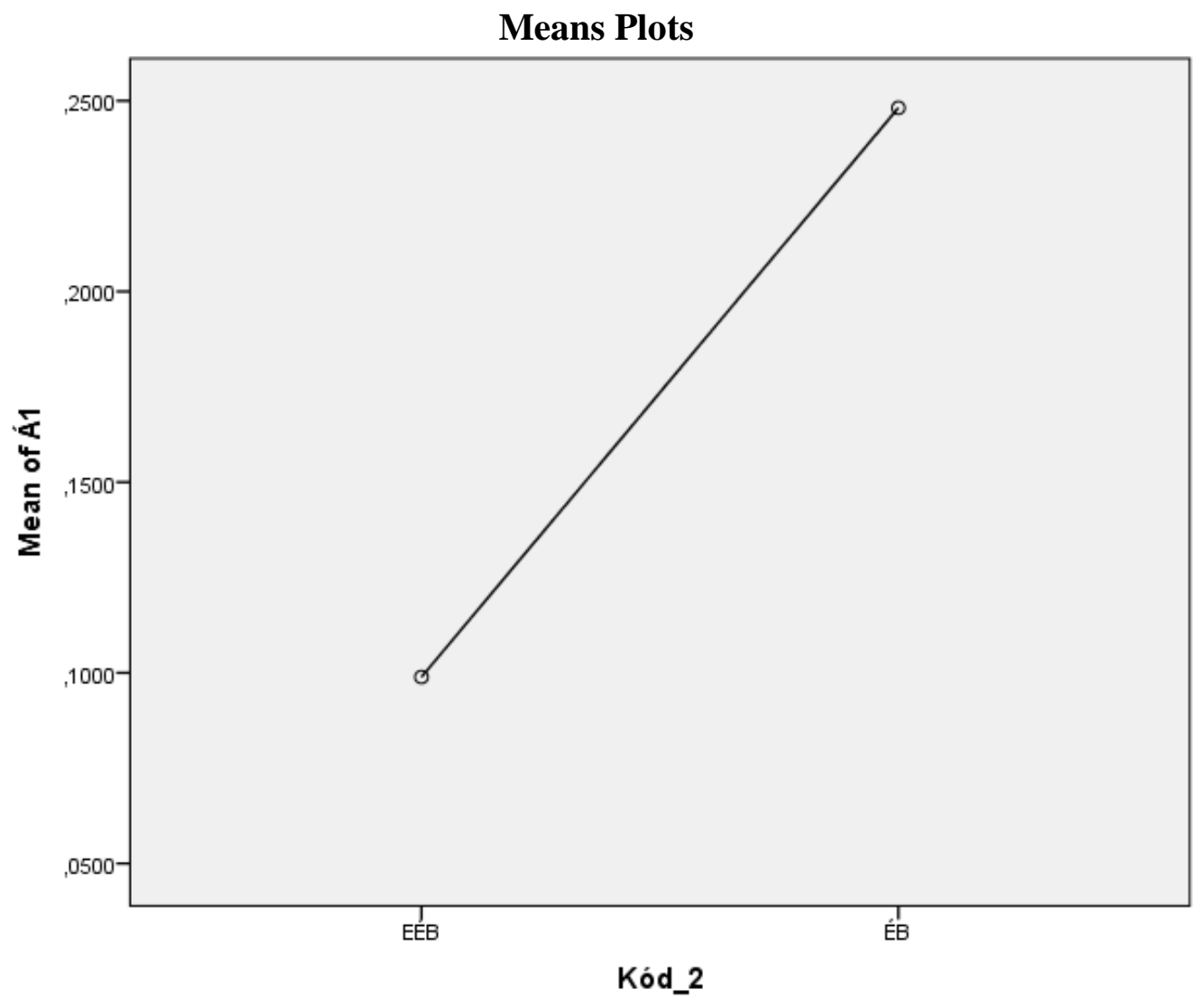


Három kategóriás elemzés: EÉ (Bt.), EÉ (Kft.), ÉB

Test of Homogeneity of Variances

\begin{tabular}{|c|c|c|c|}
\hline Levene Statistic & df1 & df2 & Sig. \\
\hline 14,531 & 2 & 127 &, 000 \\
\hline
\end{tabular}

ANOVA

\begin{tabular}{|l|r|r|r|r|r|}
\hline \multicolumn{1}{|c|}{ Á1 } & Sum of Squares & df & Mean Square & F & Sig. \\
\hline Between Groups &, 517 & 2 &, 258 & 13,091 &, 000 \\
Within Groups & 2,506 & 127 &, 020 & & \\
Total & 3,022 & 129 & & & \\
\hline
\end{tabular}

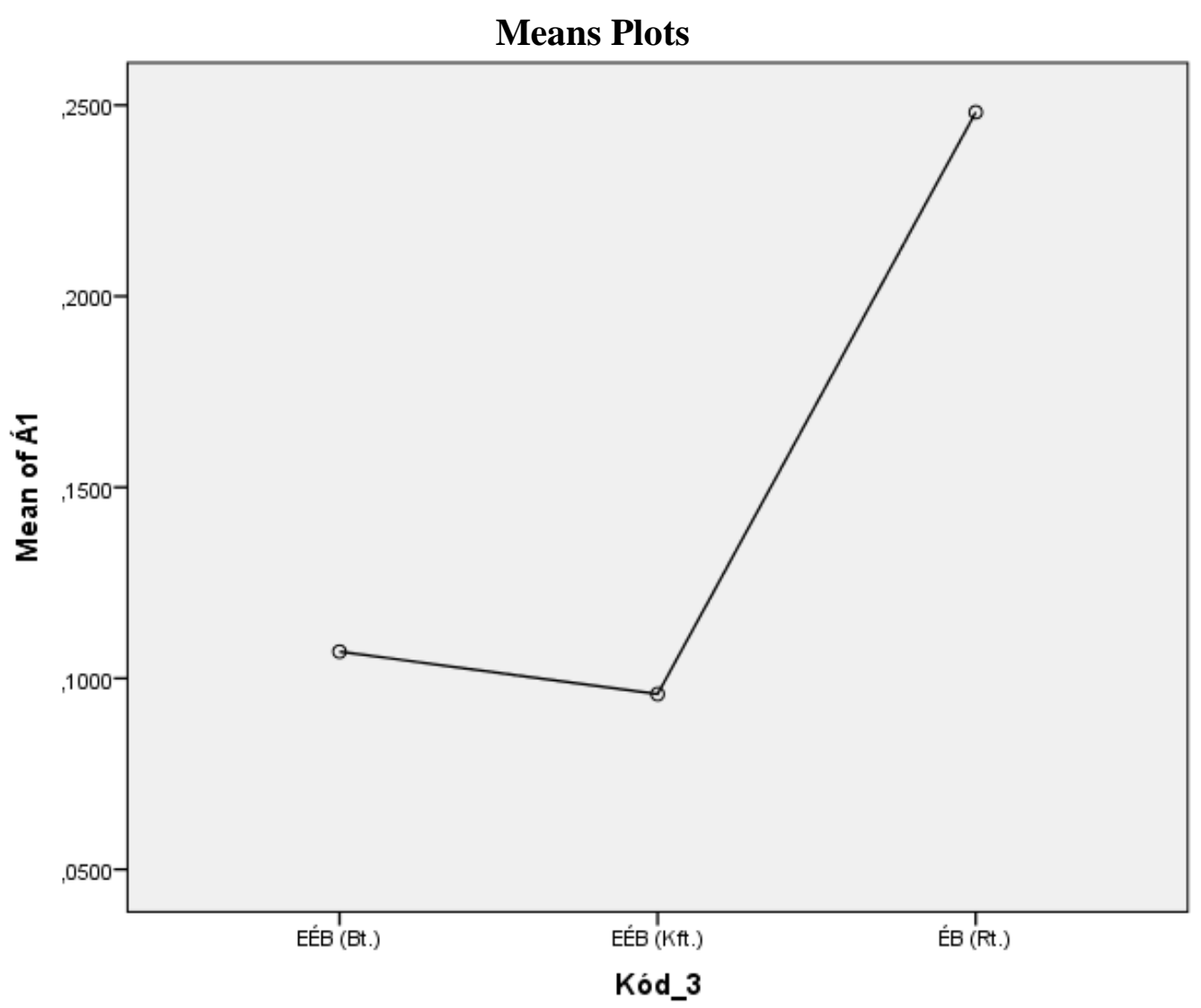




\section{Post Hoc Tests}

Multiple Comparisons (Dependent Variable: Á1; Scheffe)

\begin{tabular}{|c|c|c|c|c|c|c|}
\hline \multirow{2}{*}{ (I) Kód_3 } & \multirow{2}{*}{ (J) Kód_3 } & \multirow{2}{*}{$\begin{array}{c}\text { Mean } \\
\text { Difference (I-J) }\end{array}$} & \multirow{2}{*}{$\begin{array}{l}\text { Std. } \\
\text { Error }\end{array}$} & \multirow{2}{*}{ Sig. } & \multicolumn{2}{|c|}{ 95\% Confidence Interval } \\
\hline & & & & & Lower Bound & Upper Bound \\
\hline \multirow{2}{*}{ EÉ (Bt.) } & $\mathrm{EE}(\mathrm{Kft})$. &, 0111055 & ,0316386 & ,940 &,- 067260 &, 089471 \\
\hline & ÉB $(\mathrm{R}$ &,$- 1411523^{*}$ & ,0372611 &, 001 &,- 233444 &,- 048860 \\
\hline \multirow{2}{*}{ EÉ (Kft.) } & EÉ (Bt.) &,- 011 & ,0316386 & ,940 &,- 089471 &, 067260 \\
\hline & ÉB (I &,- 1522 & ,0304619 &, 000 &,- 227709 &,- 076807 \\
\hline \multirow{2}{*}{ ÉB (Rt.) } & EÉ (Bt.) &, $1411523^{*}$ & ,0372611 & ,001 &, 048860 & ,233444 \\
\hline & EÉ (Kft.) & $1522577^{*}$ & ,0304619 &, 000 & ,076807 & 227709 \\
\hline
\end{tabular}

$*$. The mean difference is significant at the 0.05 level.

\section{Homogeneous Subsets}

Scheffe (Á1)

\begin{tabular}{|l|r|r|r|}
\hline \multirow{2}{*}{ Kód_3 } & \multirow{2}{*}{$\mathrm{N}$} & \multicolumn{2}{|c|}{ Subset for alpha $=0.05$} \\
\cline { 3 - 4 } & & 1 & \multicolumn{1}{c|}{2} \\
\hline EÉ (Kft.) & 73 &, 095890 & \\
É́ (Bt.) & 27 &, 106996 &, 248148 \\
ÉB (Rt.) & 30 & & 1,000 \\
\hline Sig. & &, 946 & \\
\hline
\end{tabular}

Means for groups in homogeneous subsets are displayed.

a. Uses Harmonic Mean Sample Size = 35,685.

b. The group sizes are unequal. The harmonic mean of the group sizes is used. Type I error levels are not guaranteed. 


\section{7. melléklet: H2-höz alapstatisztikák}

Case Processing Summary

\begin{tabular}{|c|c|c|c|c|c|c|c|}
\hline & \multirow{3}{*}{$\begin{array}{c}\text { Beszámoló } \\
\text { típusa }\end{array}$} & \multicolumn{6}{|c|}{ Cases } \\
\hline & & \multicolumn{2}{|c|}{ Valid } & \multicolumn{2}{|c|}{ Missing } & \multicolumn{2}{|c|}{ Total } \\
\hline & & $\mathrm{N}$ & Percent & \begin{tabular}{l|}
$\mathrm{N}$ \\
\end{tabular} & Percent & $\mathrm{N}$ & Percent \\
\hline \multirow{5}{*}{ Á2 } & EÉ (Bt.) & 27 & $100,0 \%$ & 0 & $0,0 \%$ & 27 & $100,0 \%$ \\
\hline & EÉ (Kft.) & 73 & $100,0 \%$ & 0 & $0,0 \%$ & 73 & $100,0 \%$ \\
\hline & $\mathrm{EE}(\mathrm{Bt} .+\mathrm{Kft})$. & 100 & $100,0 \%$ & 0 & $0,0 \%$ & 100 & $100,0 \%$ \\
\hline & ÉB (Rt.) & 30 & $100,0 \%$ & 0 & $0,0 \%$ & 30 & $100,0 \%$ \\
\hline & Össz. & 130 & $100,0 \%$ & 0 & $0,0 \%$ & 130 & $100,0 \%$ \\
\hline
\end{tabular}

Tests of Normality ${ }^{\mathrm{a}}$

\begin{tabular}{|l|r|r|r|r|r|r|}
\hline \multirow{2}{*}{$\begin{array}{l}\text { Beszámoló } \\
\text { típusa }\end{array}$} & \multicolumn{3}{|c|}{ Kolmogorov-Smirnov } & \multicolumn{3}{c|}{ Shapiro-Wilk } \\
\cline { 2 - 7 } & Statistic & \multicolumn{1}{c|}{ df } & \multicolumn{1}{c|}{ Sig. } & Statistic & df & \multicolumn{1}{c|}{ Sig. } \\
\hline \multirow{4}{*}{ EÉ (Bt.) } &, 535 & 73 &, 000 &, 149 & 73 &, 000 \\
EÉ (Kft.) &, 534 & 100 &, 000 &, 119 & 100 &, 000 \\
Á1 &, 281 & 30 &, 000 &, 746 & 30 &, 000 \\
EÉ (Bt.+Kft.) &, 501 & 130 &, 000 &, 383 & 130 &, 000 \\
ÉB (Rt.) &, 535 & 73 &, 000 &, 149 & 73 &, 000 \\
Össz. & &
\end{tabular}

a. Á2 is constant when Kód_5 = EÉ (Bt.). It has been omitted.

b. Lilliefors Significance Correction

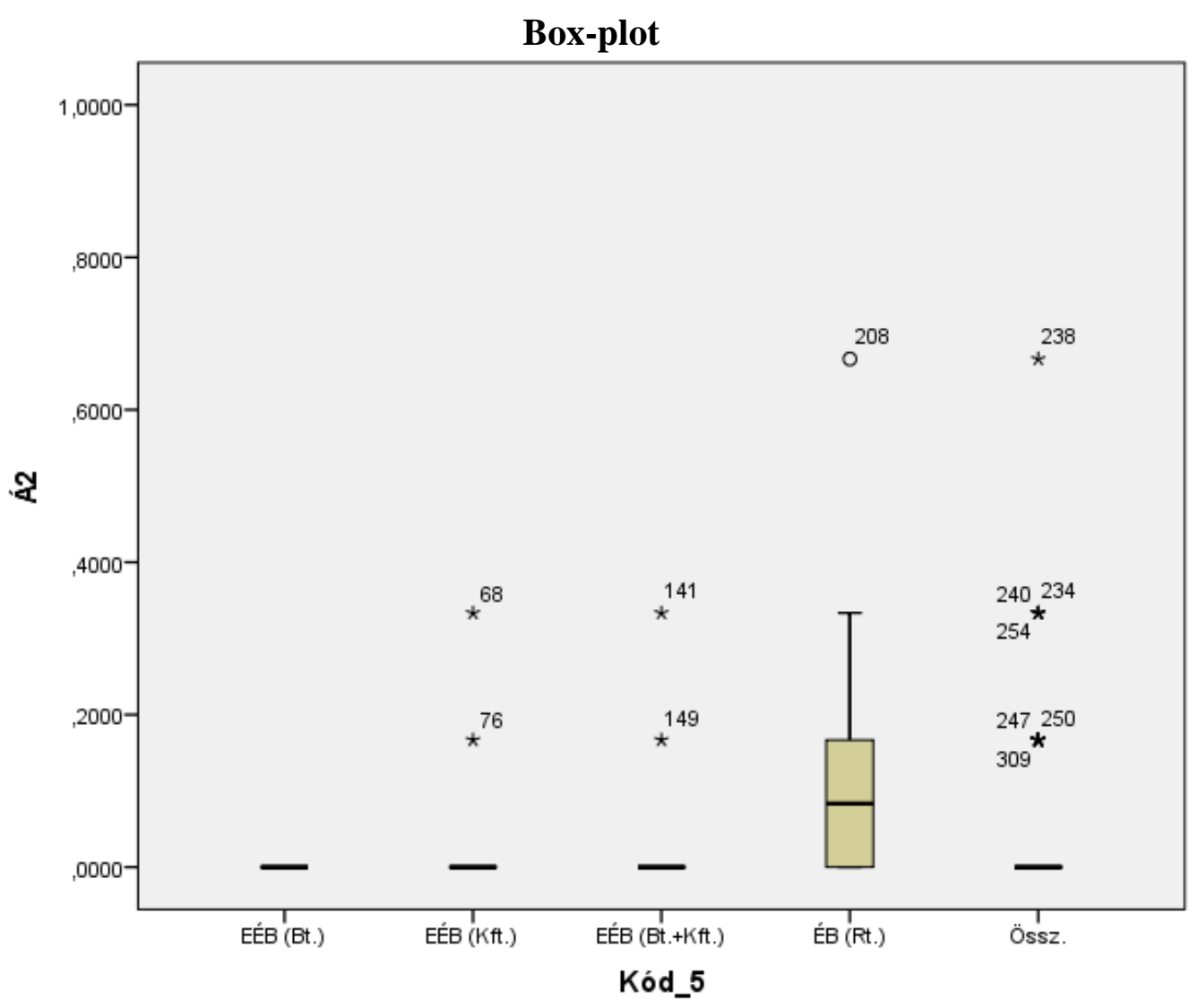




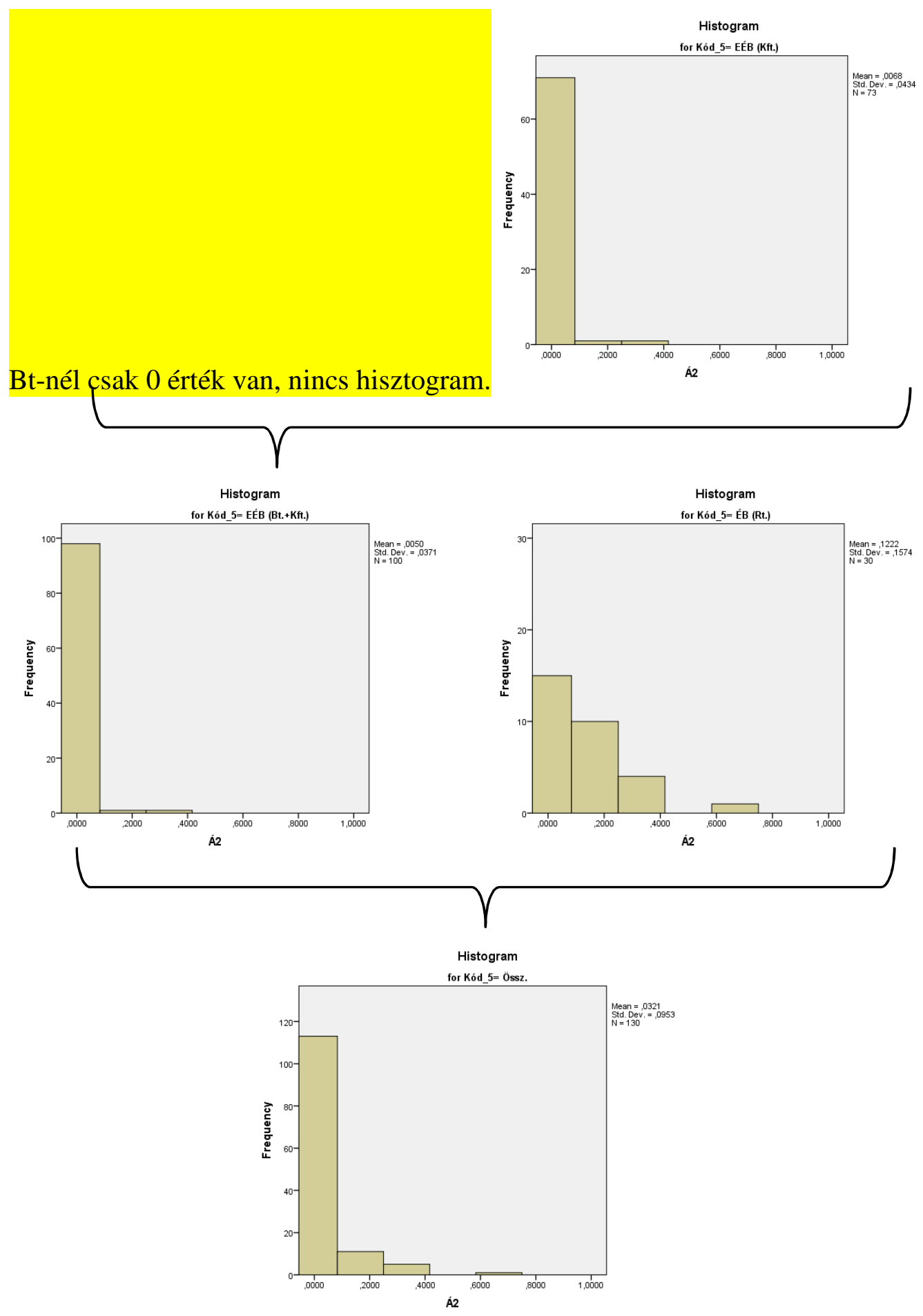


Normal Q-Q + Detrended Normal Q-Q

Bt-nél csak 0 érték van, nincs ábra.
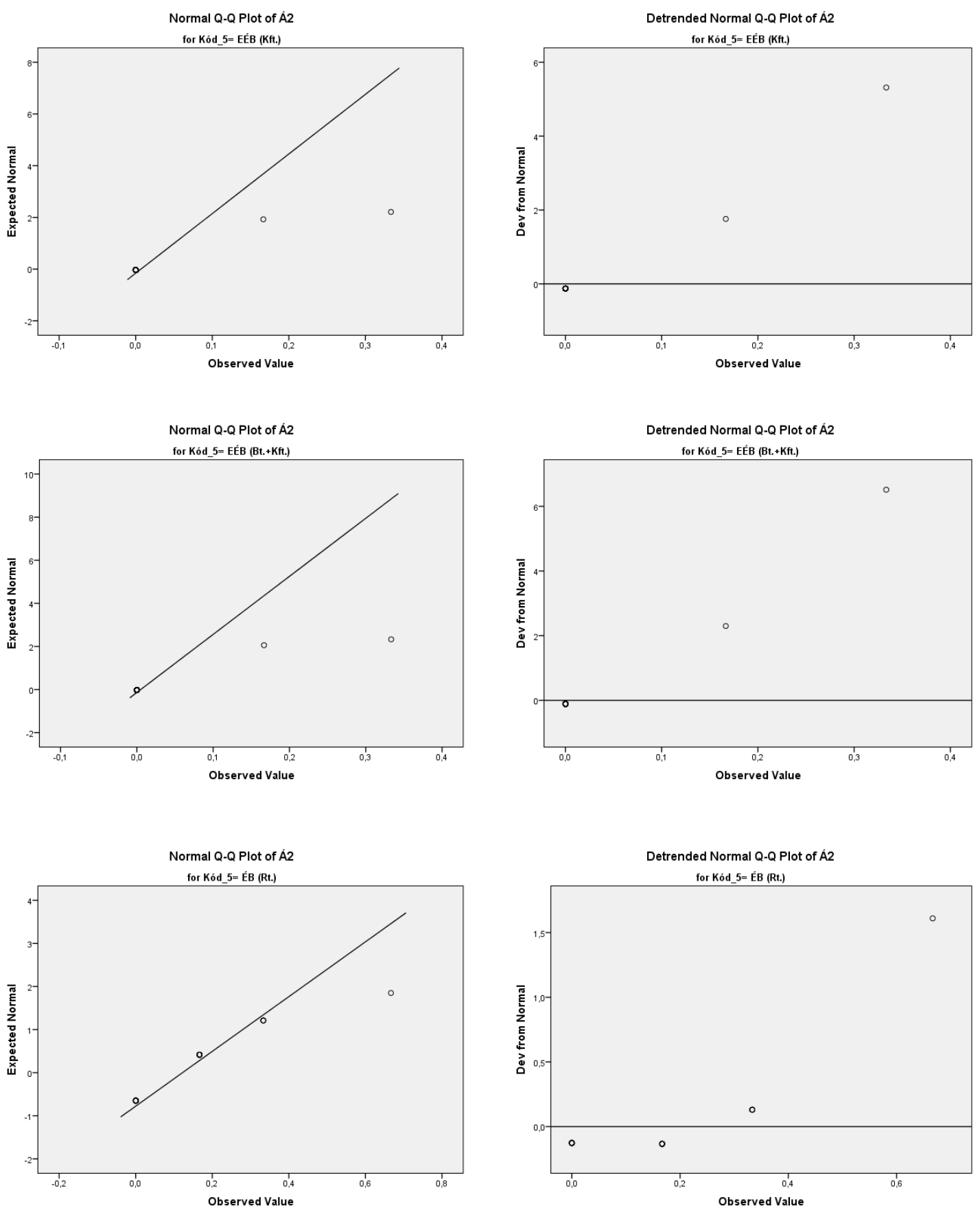

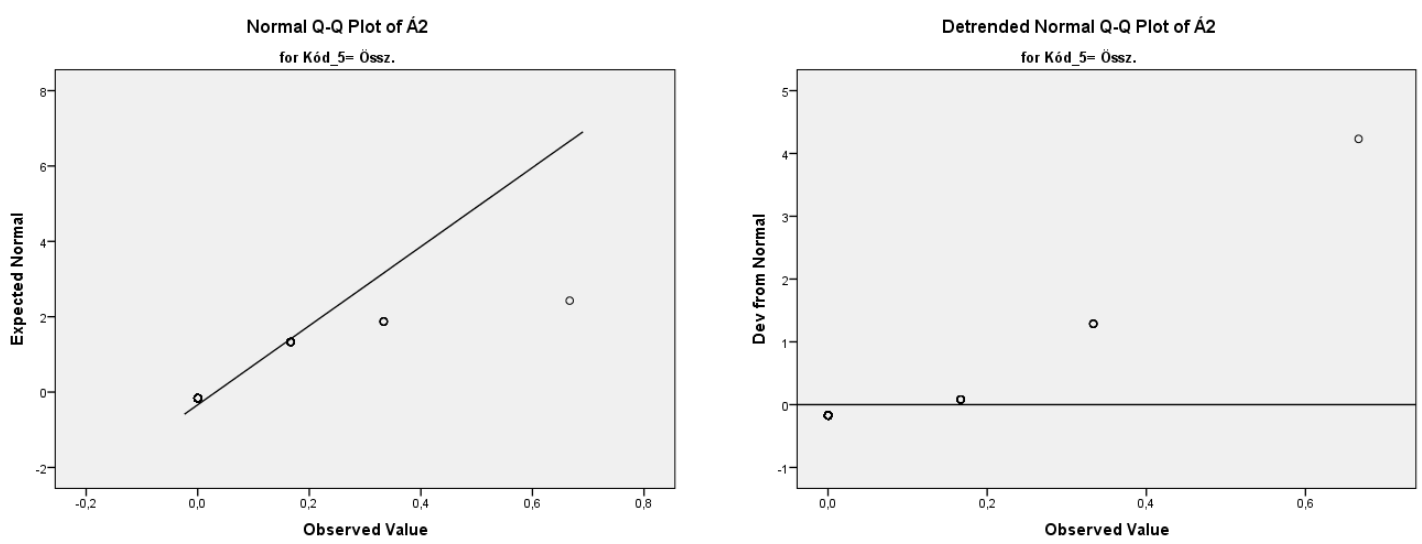


\section{8. melléklet: H2-höz varianciaanalízis}

\begin{tabular}{|c|c|c|c|c|c|c|c|c|}
\hline \multicolumn{9}{|c|}{ Descriptives } \\
\hline \multirow{2}{*}{ Á2 } & \multirow{2}{*}{$\mathrm{N}$} & \multirow{2}{*}{ Mean } & \multirow{2}{*}{$\begin{array}{c}\text { Std. } \\
\text { Deviation }\end{array}$} & \multirow{2}{*}{\begin{tabular}{c|} 
Std. \\
Error
\end{tabular}} & \multicolumn{2}{|c|}{ 95\% Confidence Interval for Mean } & \multirow{2}{*}{ Min. } & \multirow{2}{*}{ Max. } \\
\hline & & & & & Lower Bound & Upper Bound & & \\
\hline EÉ (Bt.) & 27 & ,000000 & 0E-7 & 0E-7 & ,000000 &, 000000 &, 0000 &, 0000 \\
\hline & 73 & & ,0433 & ,0050767 & & & 0000 & 33, \\
\hline EÉ (Bt.+Kft.) & 100 & 005000 & 771169 & ,0037117 &,- 002365 & 012365 & 0000 &, $33 ?$ \\
\hline ÉB (Rt.) & 30 & 122222 & ,1574055 & ,0287382 & ,063446 & 180998 & ,0000 & ,666 \\
\hline Össz. & 130 & 032051 & ,0953170 & ,0083599 & 015 & 048591 & ,0000 & ,666 \\
\hline Total & 360 & 024537 & ,0840025 & ,0044273 & 015830 & 033244 & ,0000 & 6667 \\
\hline
\end{tabular}

Két kategóriás elemzés: EÉ, ÉB

Test of Homogeneity of Variances

\begin{tabular}{|c|c|c|c|}
\hline Levene Statistic & df1 & df 2 & Sig. \\
\hline 94,001 & 1 & 128 &, 000 \\
\hline
\end{tabular}

ANOVA

\begin{tabular}{|l|r|r|r|c|c|}
\hline \multicolumn{1}{|c|}{ Á1 } & Sum of Squares & df & Mean Square & F & Sig. \\
\hline Between Groups &, 317 & 1 &, 317 & 47,478 &, 000 \\
Within Groups &, 855 & 128 &, 007 & & \\
Total & 1,172 & 129 & & & \\
\hline
\end{tabular}

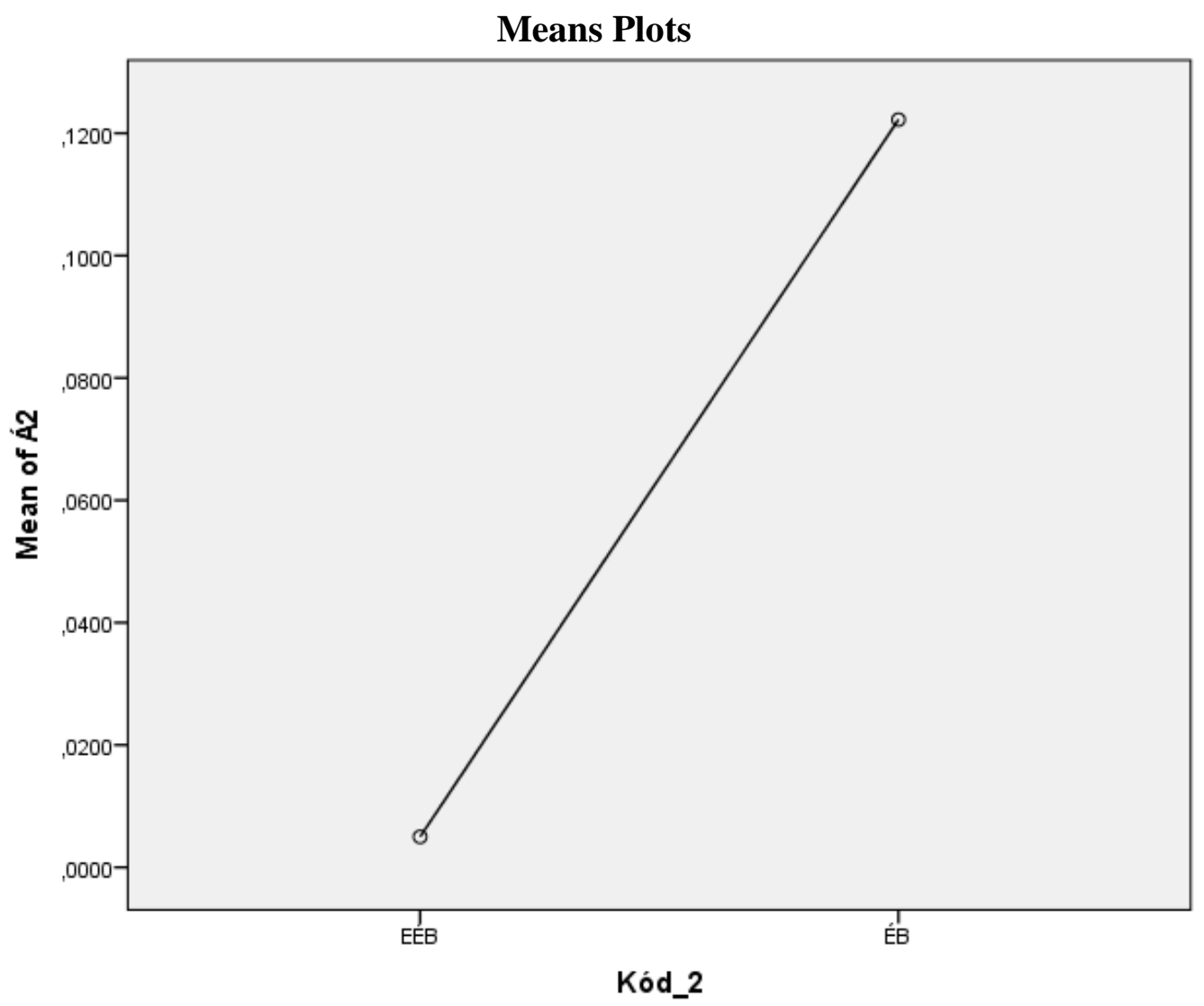


Három kategóriás elemzés: EÉ (Bt.), EÉ (Kft.), ÉB

Test of Homogeneity of Variances

\begin{tabular}{|c|c|c|c|}
\hline Levene Statistic & df1 & df2 & Sig. \\
\hline 47,769 & 2 & 127 & ,000 \\
\hline
\end{tabular}

ANOVA

\begin{tabular}{|l|r|r|r|r|r|}
\hline \multicolumn{1}{|c|}{ Á2 } & Sum of Squares & df & Mean Square & F & Sig. \\
\hline Between Groups &, 318 & 2 &, 159 & 23,648 &, 000 \\
Within Groups &, 854 & 127 &, 007 & & \\
Total & 1,172 & 129 & & & \\
\hline
\end{tabular}

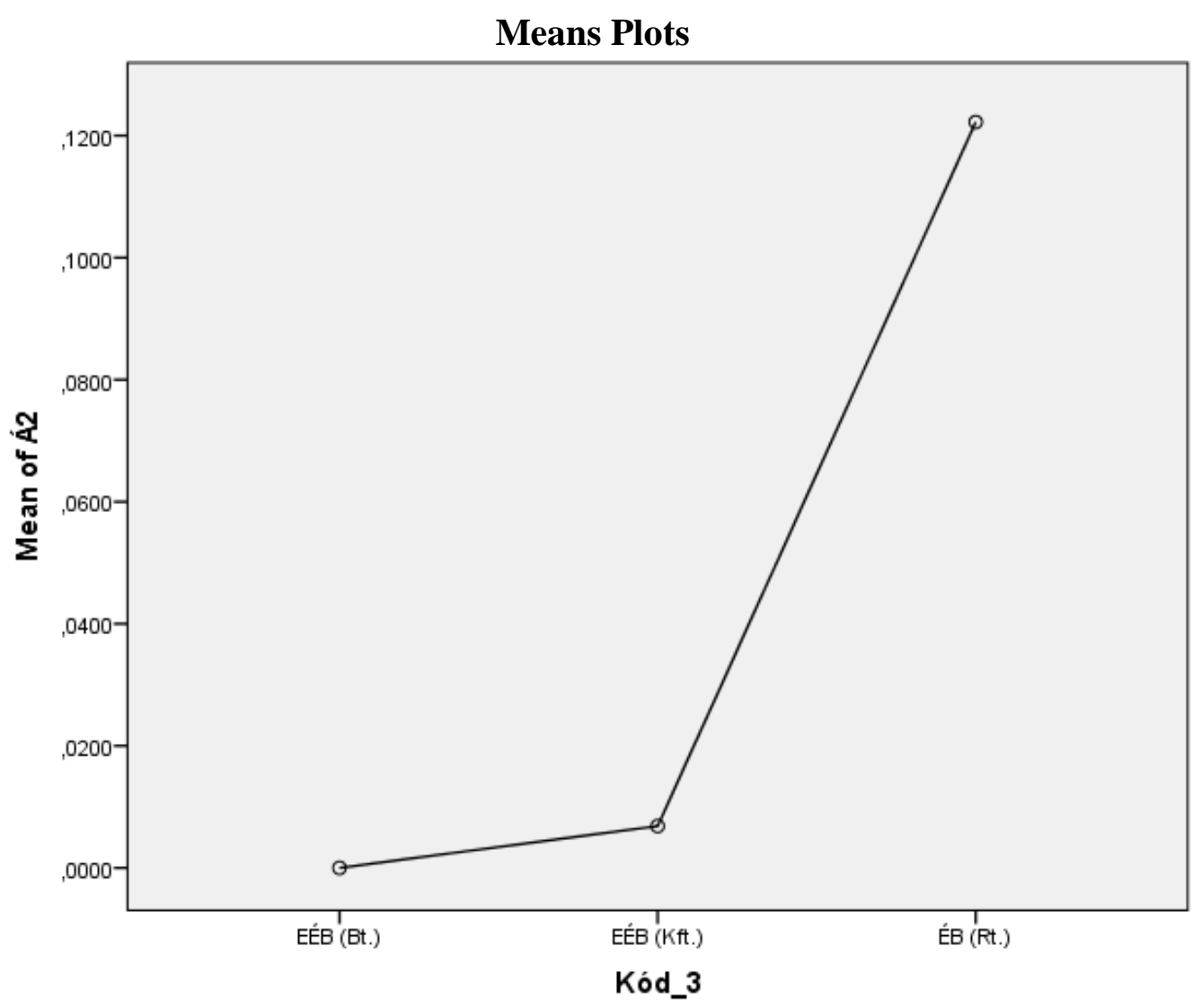




\section{Post Hoc Tests}

Multiple Comparisons (Dependent Variable: Á2; Scheffe)

\begin{tabular}{|c|c|c|c|c|c|c|}
\hline \multirow{2}{*}{ (I) Kód_3 } & \multirow{2}{*}{ (J) Kód_3 } & \multirow{2}{*}{$\begin{array}{c}\text { Mean } \\
\text { Difference (I-J) }\end{array}$} & \multirow{2}{*}{$\begin{array}{l}\text { Std. } \\
\text { Error }\end{array}$} & \multirow{2}{*}{ Sig. } & \multicolumn{2}{|c|}{ 95\% Confidence Interval } \\
\hline & & & & & Lower Bound & Upper Bound \\
\hline \multirow{2}{*}{ EÉ (Bt.) } & EÉ (Kft.) &,- 0068493 & 0184705 & ,934 &,- 052599 &, 038900 \\
\hline & ÉB $(\mathrm{R}$ &,$- 1222222^{*}$ &, 0217529 &, 000 &,- 17 &,- 068342 \\
\hline \multirow{2}{*}{ EÉ (Kft.) } & EÉ (Bt.) & ,0068493 & 0184705 & ,934 &,- 038900 & ,052599 \\
\hline & ÉB (Rt.) &,$- 1153729^{*}$ & ,0177836 &, 000 &,- 159 &,- 071325 \\
\hline \multirow{2}{*}{ ÉB (Rt.) } & EÉ (Bt.) &, $1222222^{*}$ & ,0217529 & ,000 & ,068342 &, 176102 \\
\hline & EÉ (Kft.) &, $1153729^{*}$ & ,0177836 &, 000 &, 071325 & ,159421 \\
\hline
\end{tabular}

$*$. The mean difference is significant at the 0.05 level.

\section{Homogeneous Subsets}

Scheffe (Á2)

\begin{tabular}{|l|r|r|r|}
\hline \multirow{2}{*}{ Kód_3 } & \multirow{2}{*}{$\mathrm{N}$} & \multicolumn{2}{|c|}{ Subset for alpha $=0.05$} \\
\cline { 3 - 4 } & & 1 & \multicolumn{1}{c|}{2} \\
\hline EÉ (Kft.) & 73 &, 000000 & \\
É́ (Bt.) & 27 &, 006849 &, 122222 \\
ÉB (Rt.) & 30 & & 1,000 \\
\hline Sig. & &, 940 &, \\
\hline
\end{tabular}

Means for groups in homogeneous subsets are displayed.

a. Uses Harmonic Mean Sample Size = 35,685.

b. The group sizes are unequal. The harmonic mean of the group sizes is used. Type I error levels are not guaranteed. 


\section{9. melléklet: H3-hoz alapstatisztikák}

\section{Stem-and-Leaf Plots}

EltérR Stem-and-Leaf Plot for B_Kat= MG

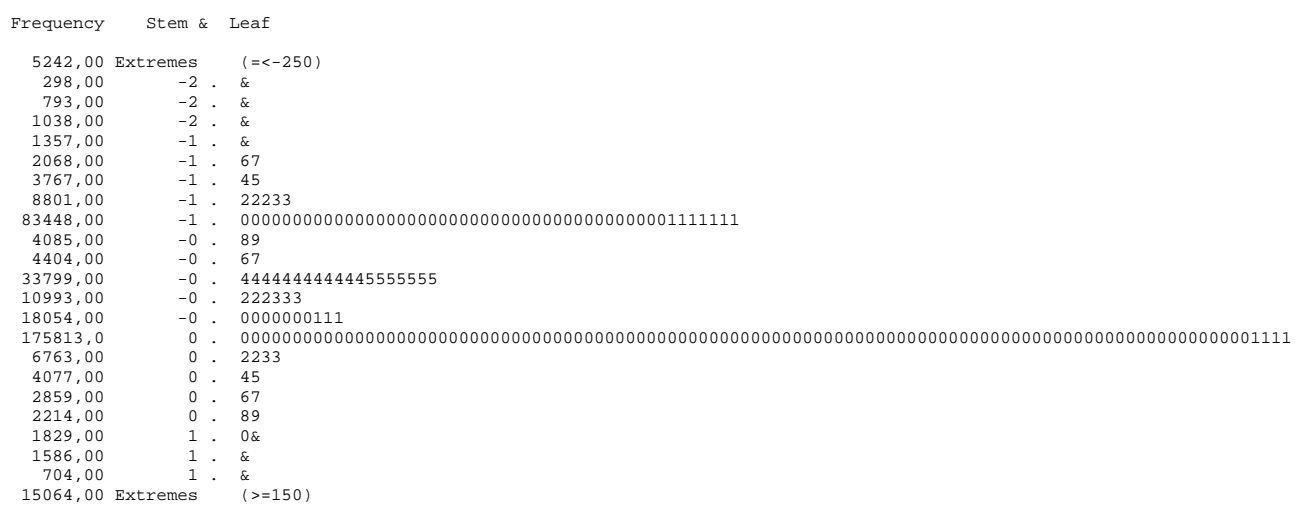

Stem width: 100,00 Each leaf: 1741 case(s) \& denotes fractional leaves.

EltérR Stem-and-Leaf Plot for B_Kat= EÉ

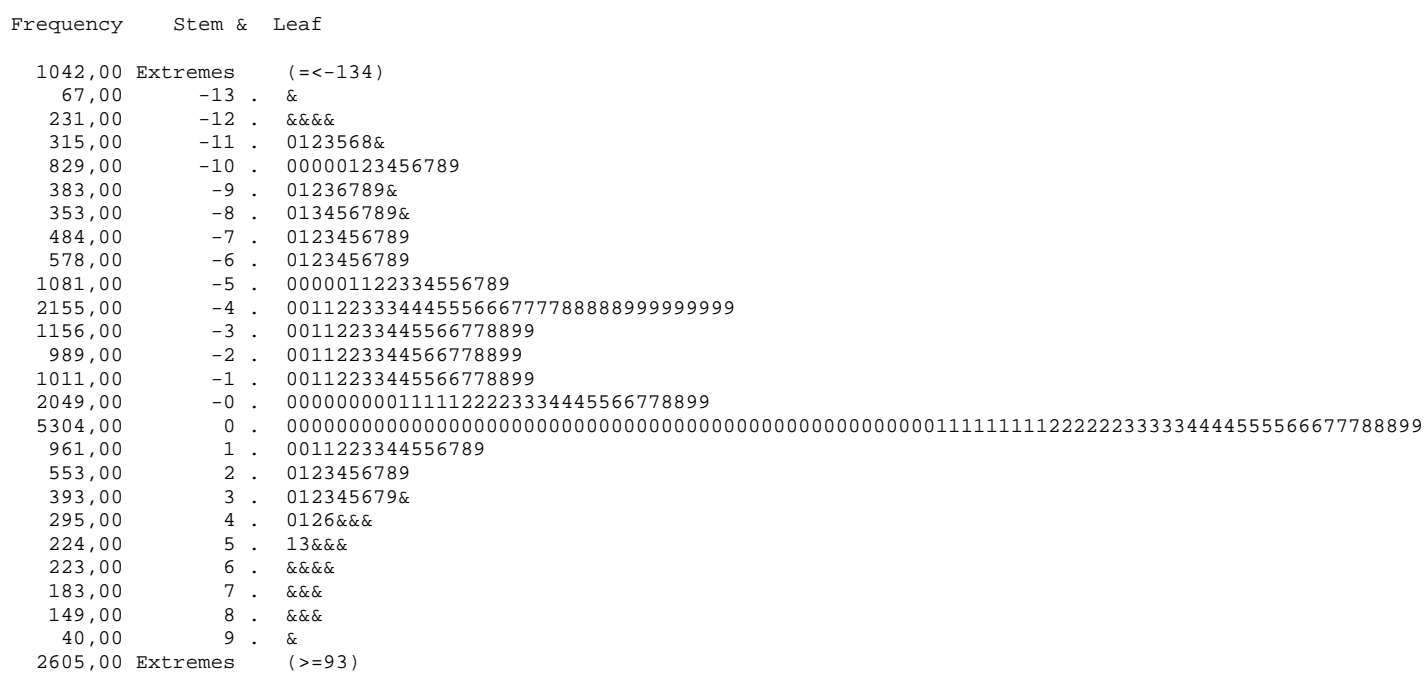


EltérR Stem-and-Leaf Plot for B_Kat= ÉB

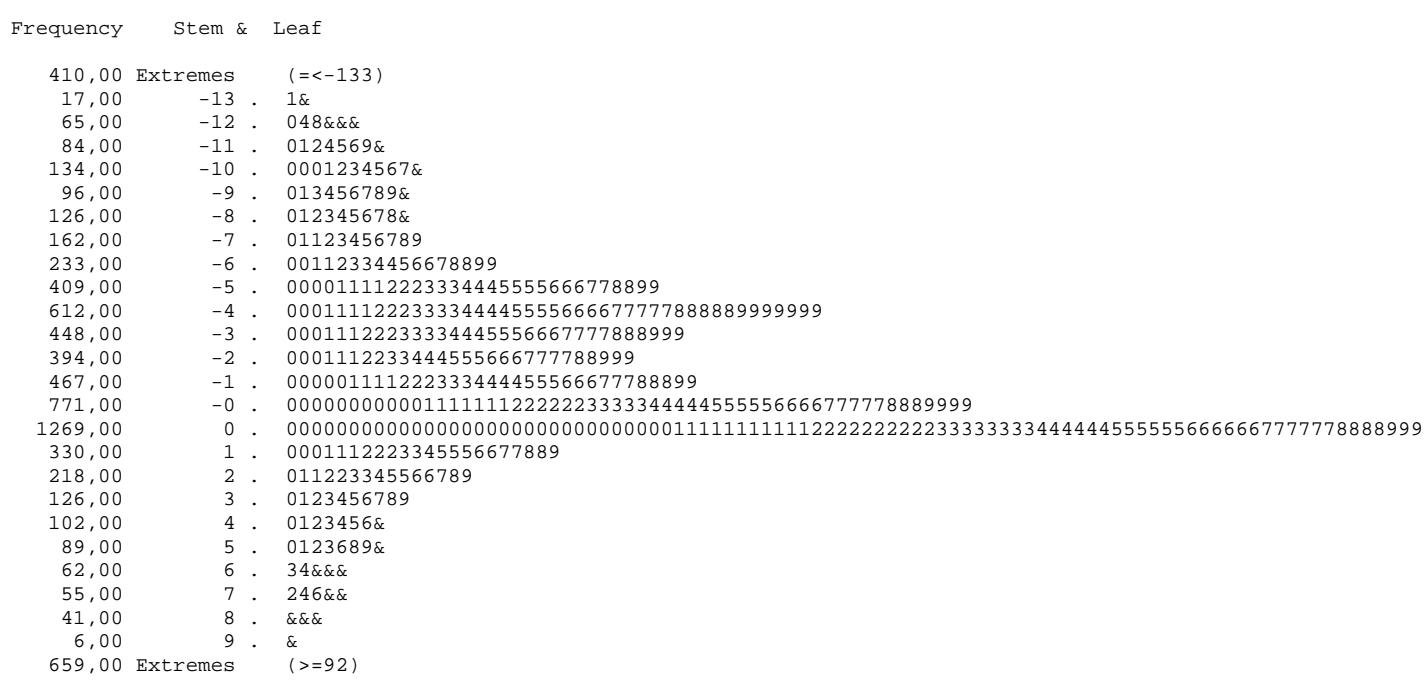

Stem width: 10,00

Each leaf: 14 case(s)

$\&$ denotes fractional leaves.

\section{Box plots (teljes)}

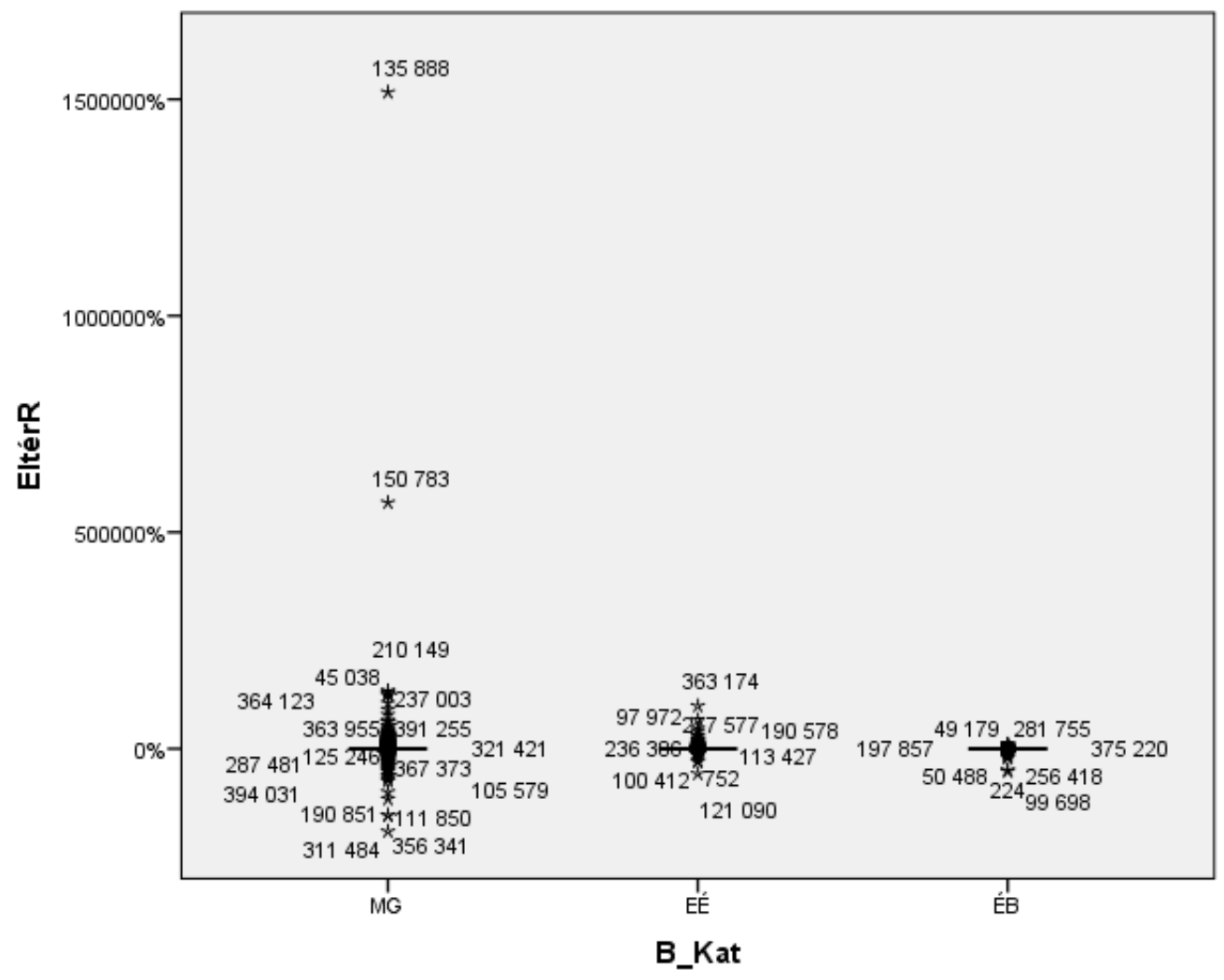




\section{Box plots (két nagyon extrém kihagyásával)}

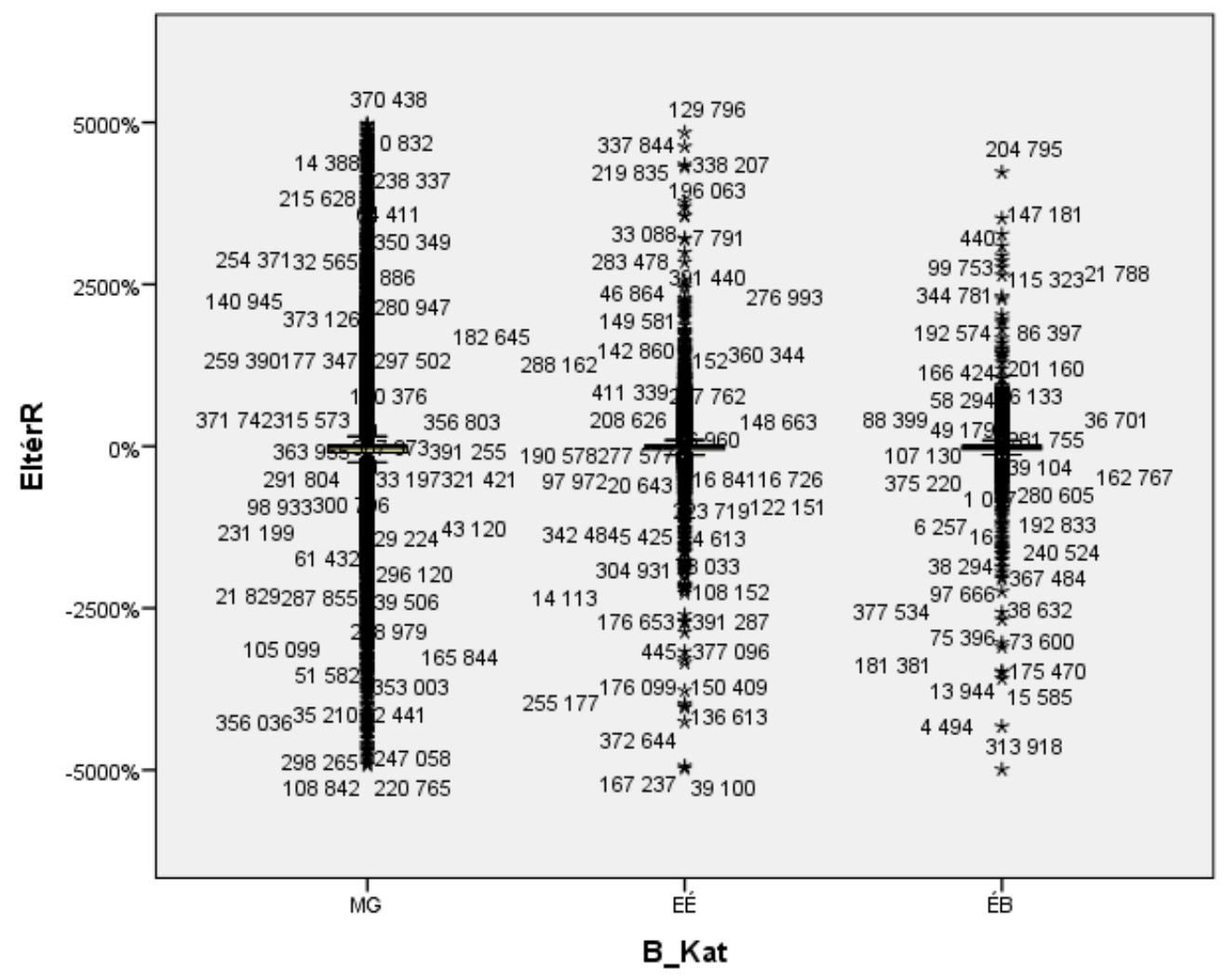

\section{Stem-and-Leaf Plots}

EltérRA Stem-and-Leaf Plot for B_Kat= MG

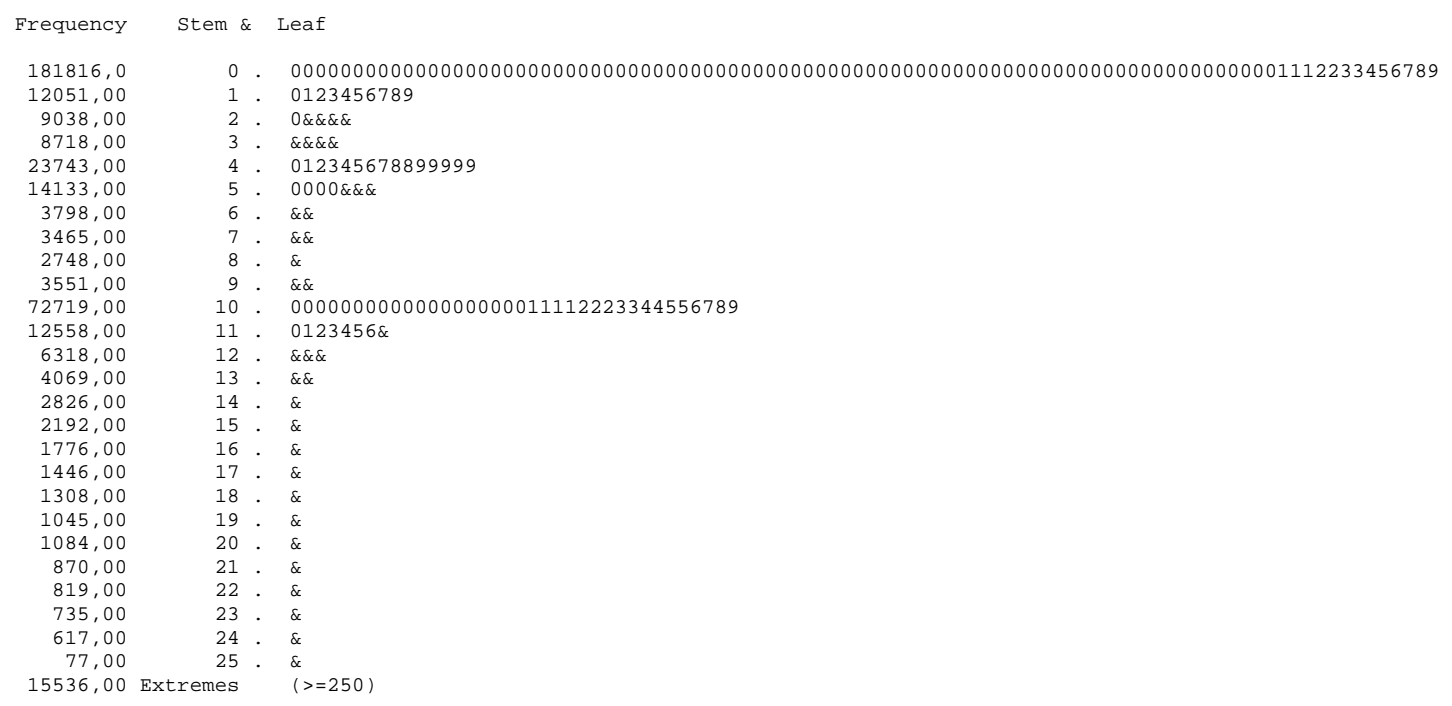

Stem width: 10,00

Each leaf: 1956 case(s)

$\&$ denotes fractional leaves. 


\section{EltérRA Stem-and-Leaf Plot for B_Kat= EÉ}

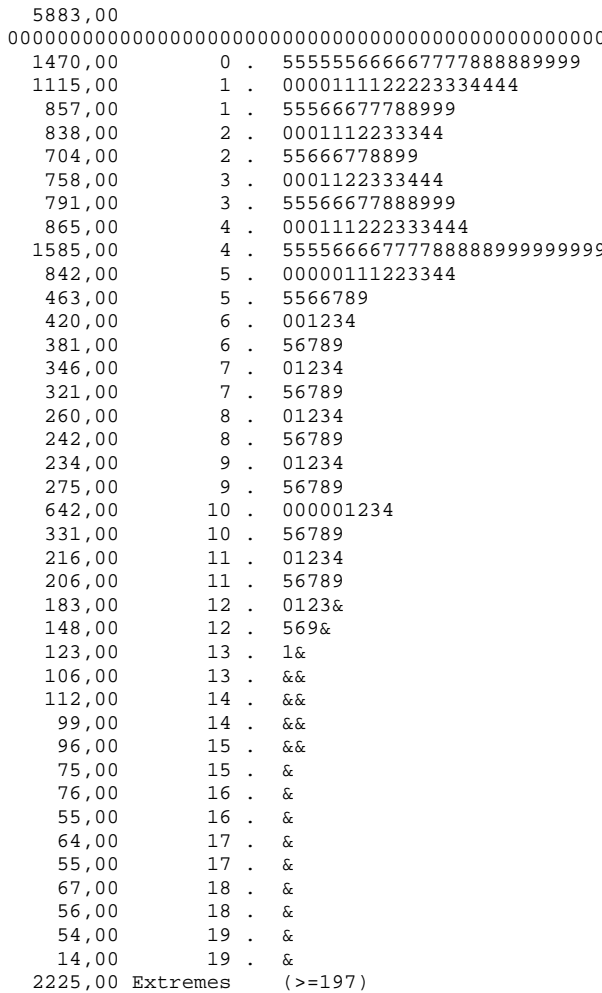

\section{EltérRA Stem-and-Leaf Plot for B_Kat= ÉB}

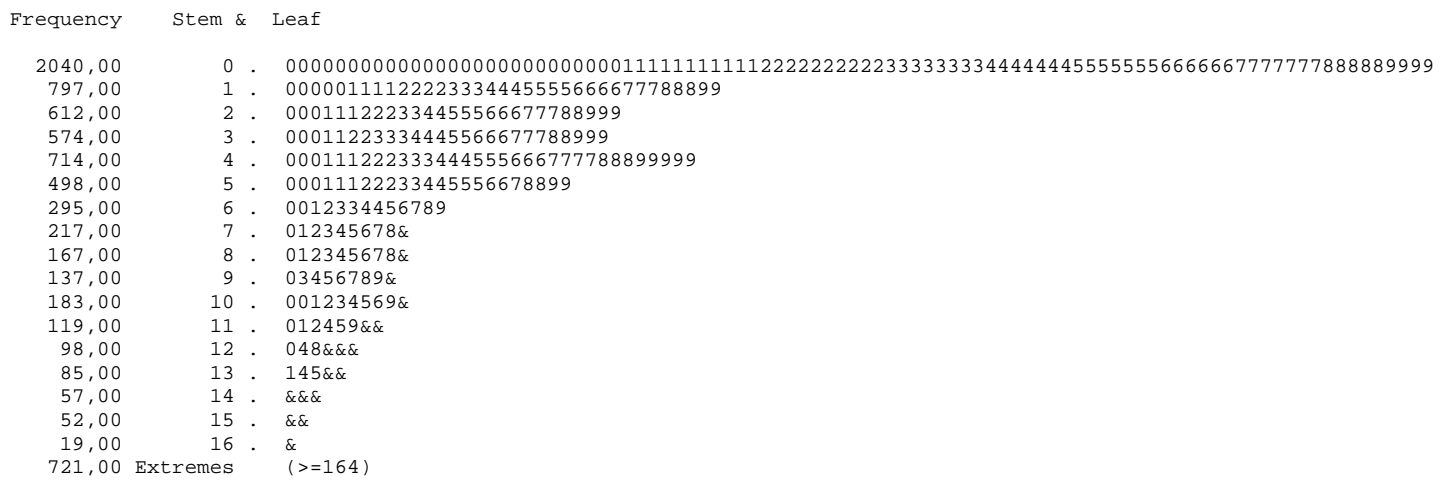

Stem width: 10,00 


\section{Box plots (teljes)}

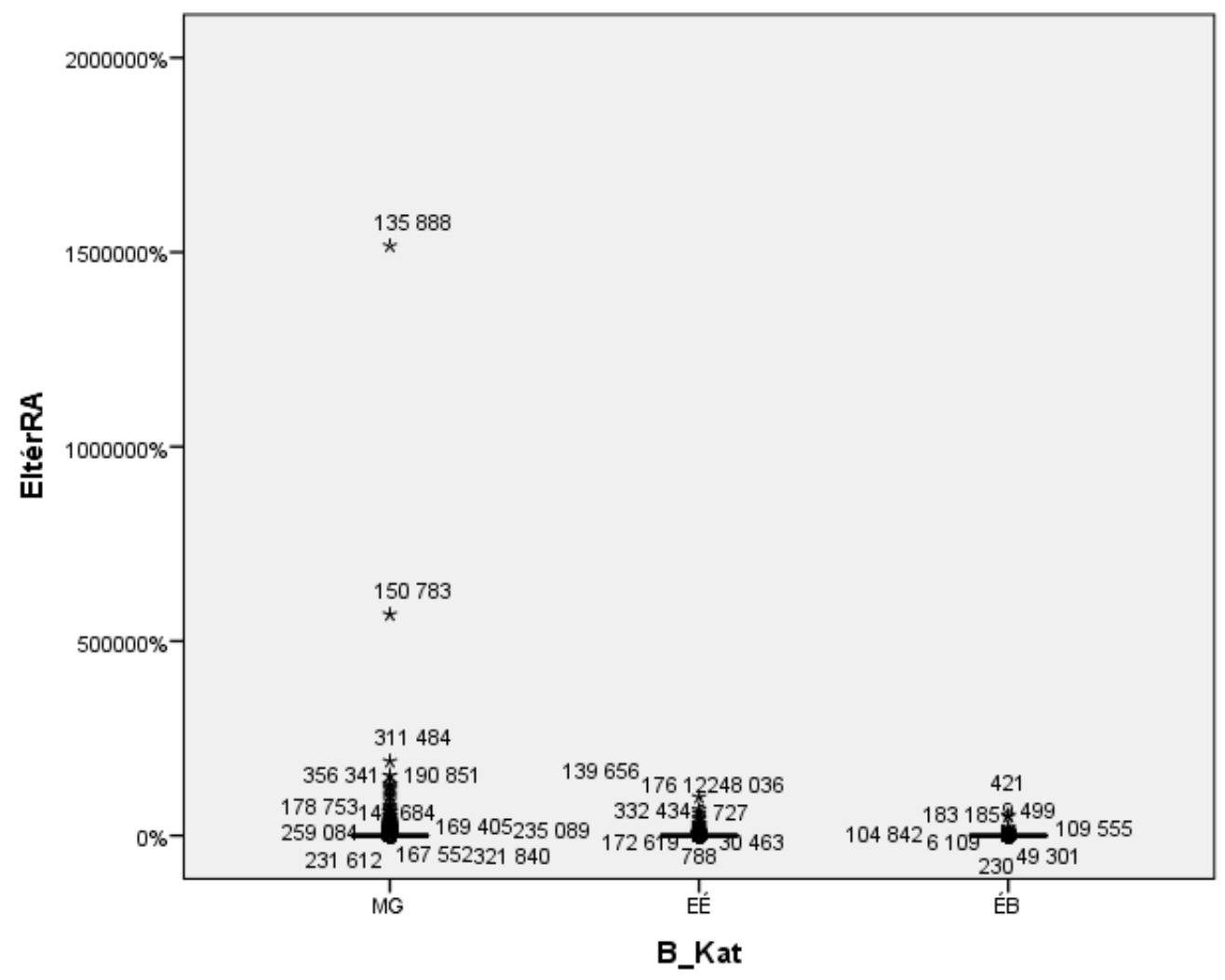

\section{Box plots (két nagyon extrém kihagyásával)}

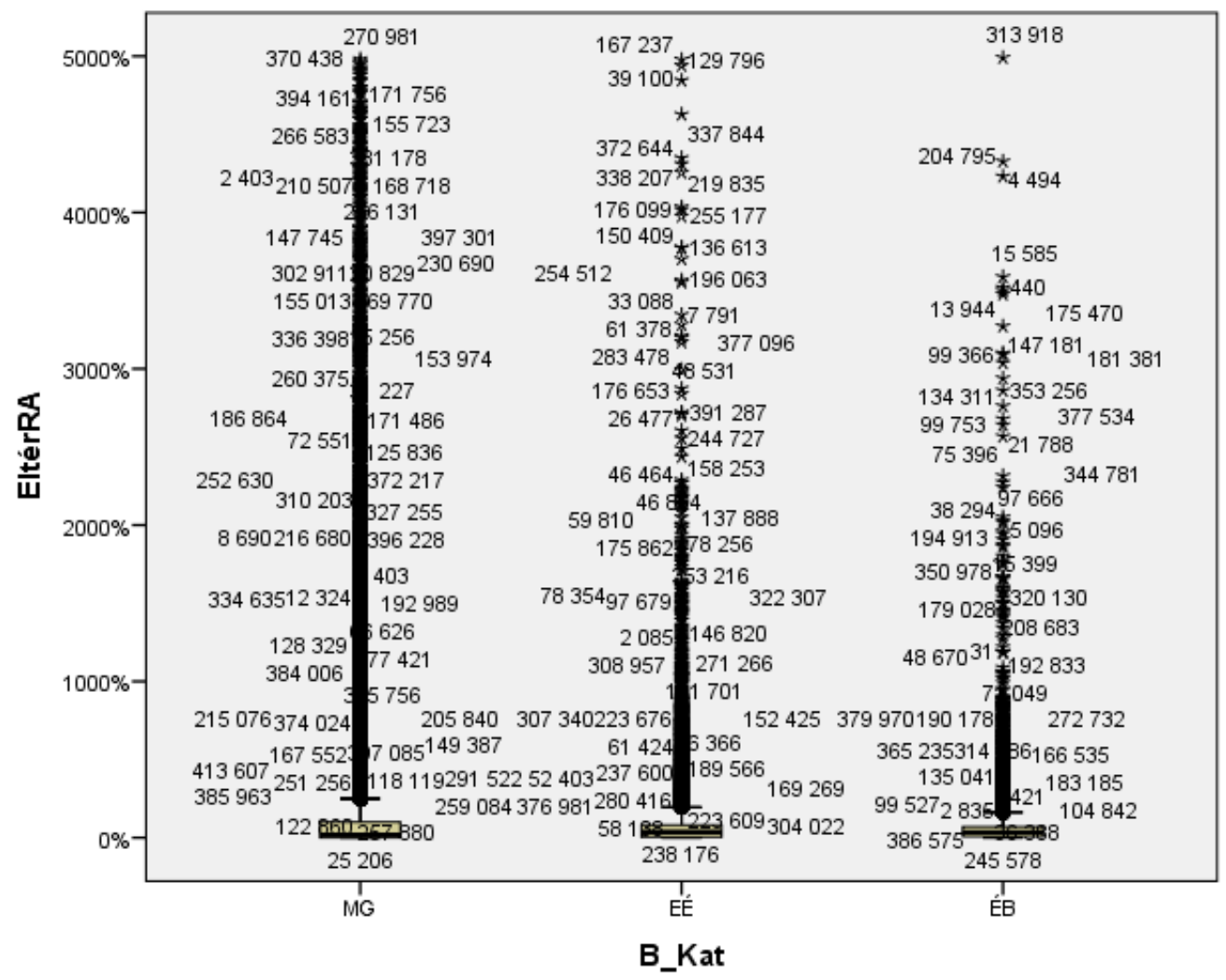


Többváltozós (teljes)

Descriptives

\begin{tabular}{|c|c|c|c|c|c|c|c|c|}
\hline \multirow{2}{*}{ EltérRA } & \multirow{2}{*}{$\mathrm{N}$} & \multirow{2}{*}{ Mean } & \multirow{2}{*}{$\begin{array}{c}\text { Std. } \\
\text { Deviation }\end{array}$} & \multirow{2}{*}{$\begin{array}{l}\text { Std. } \\
\text { Error }\end{array}$} & \multicolumn{2}{|c|}{$\begin{array}{l}\text { 95\% Confidence } \\
\text { Interval for Mean }\end{array}$} & \multirow{2}{*}{ Min. } & \multirow{2}{*}{ Max. } \\
\hline & & & & & $\begin{array}{l}\text { Lower } \\
\text { Bound }\end{array}$ & $\begin{array}{l}\text { Upper } \\
\text { Bound }\end{array}$ & & \\
\hline MG & 389056 & $91,929 \%$ & $2760,5120 \%$ & $4,4257 \%$ & $83,255 \%$ & $100,603 \%$ & $0,00 \%$ & $1516300,00 \%$ \\
\hline EÉ & 23653 & $116,568 \%$ & $1108,8034 \%$ & $7,2096 \%$ & $102,436 \%$ & $130,699 \%$ & $0,00 \%$ & $98800,00 \%$ \\
\hline ÉB & 7385 & $119,158 \%$ & $1003,5528 \%$ & $11,6779 \%$ & $96,266 \%$ & $142,050 \%$ & $0,00 \%$ & $52293,92 \%$ \\
\hline Total & 420094 & $93,795 \%$ & $2672,8950 \%$ & $4,1239 \%$ & $85,712 \%$ & $101,878 \%$ & $0,00 \%$ & $1516300,00 \%$ \\
\hline
\end{tabular}

Test of Homogeneity of Variances

\begin{tabular}{|c|c|c|c|}
\hline Levene Statistic & df1 & df2 & Sig. \\
\hline 2,935 & 2 & 420091 & ,053 \\
\hline
\end{tabular}

ANOVA

\begin{tabular}{|l|r|r|r|r|r|}
\hline \multicolumn{1}{|c|}{ EltérRA } & \multicolumn{1}{c|}{ Sum of Squares } & df & Mean Square & F & \multicolumn{1}{c|}{ Sig. } \\
\hline Between Groups & 18371491,719 & 2 & 9185745,860 & 1,286 &, 276 \\
Within Groups & 3001280463424,859 & 420091 & 7144357,921 & & \\
Total & 3001298834916,579 & 420093 & & & \\
\hline
\end{tabular}

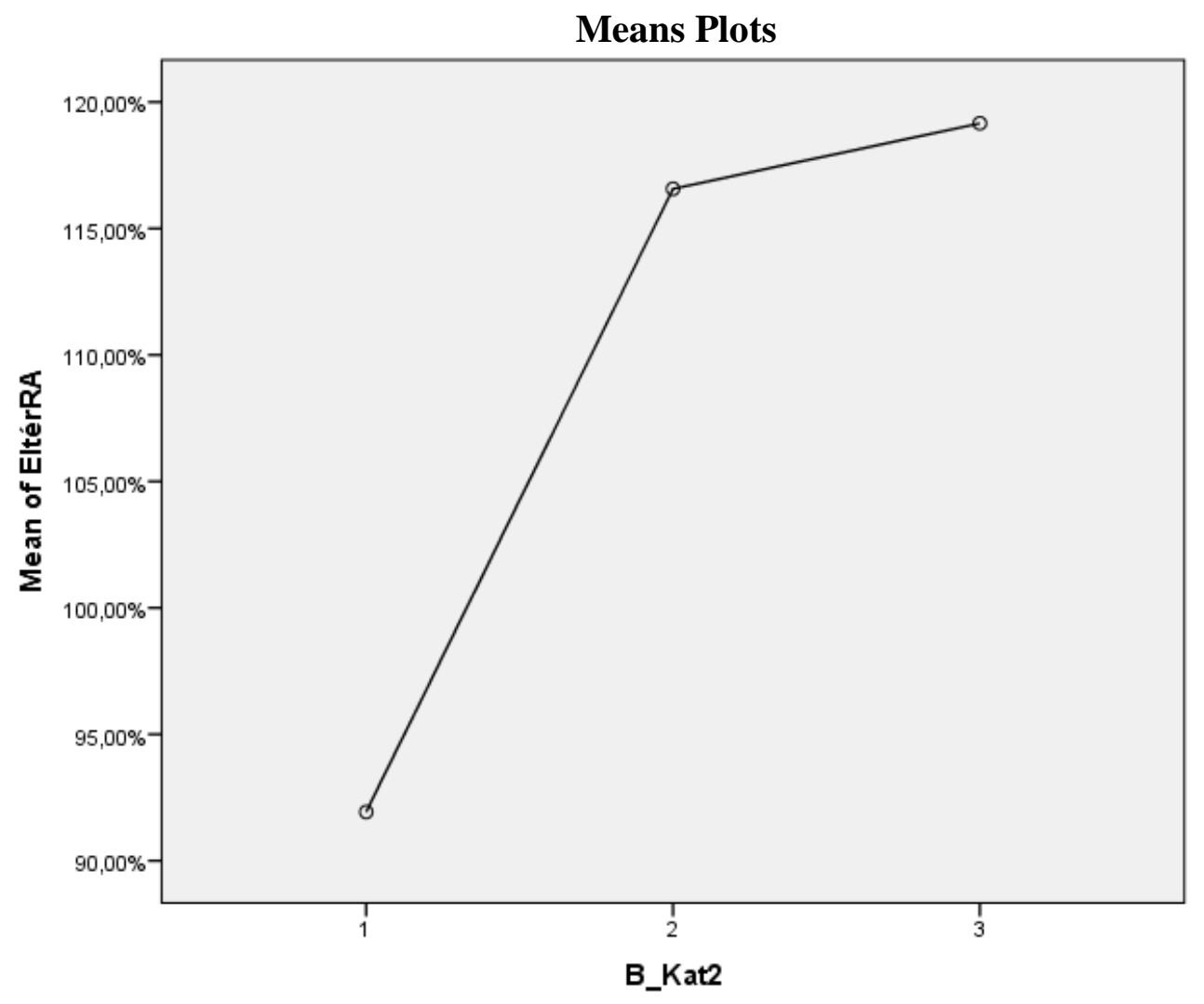




\section{Post Hoc Tests}

Multiple Comparisons (Dependent Variable: EltérRA; Scheffe)

\begin{tabular}{|l|l|r|r|r|r|r|}
\hline \multirow{2}{*}{ (I) } & \multicolumn{1}{c|}{$(\mathrm{J})$} & \multicolumn{1}{c|}{ Mean } & \multicolumn{1}{c|}{ Std. } & \multirow{2}{*}{ Sig. } & \multicolumn{2}{|c|}{ 95\% Confidence Interval } \\
\cline { 6 - 7 } B_Kat2 & B_Kat2 & Difference (I-J) & Error & & Lower Bound & Upper Bound \\
\hline \multirow{2}{*}{ MG } & EÉ & $-24,63855 \%$ & $17,90006 \%$ &, 388 & $-68,4535 \%$ & $19,1764 \%$ \\
& ÉB & $-27,22899 \%$ & $31,39710 \%$ &, 687 & $-104,0814 \%$ & $49,6234 \%$ \\
\hline \multirow{2}{*}{ É́ } & MG & $24,63855 \%$ & $17,90006 \%$ &, 388 & $-19,1764 \%$ & $68,4535 \%$ \\
& ÉB & $-2,59044 \%$ & $35,62953 \%$ &, 997 & $-89,8028 \%$ & $84,6219 \%$ \\
\hline \multirow{2}{*}{ ÉB } & MG & $27,22899 \%$ & $31,39710 \%$ &, 687 & $-49,6234 \%$ & $104,0814 \%$ \\
& EÉ & $2,59044 \%$ & $35,62953 \%$ &, 997 & $-84,6219 \%$ & $89,8028 \%$ \\
\hline
\end{tabular}

\section{Homogeneous Subsets}

\begin{tabular}{|l|r|r|}
\multicolumn{3}{|c|}{ Scheffe $^{\mathrm{a}, \mathrm{b}}$ (EltérRA) } \\
\cline { 3 - 3 } B_Kat2 & \multirow{2}{*}{$\mathrm{N}$} & \multicolumn{2}{|c|}{ Subset for alpha $=0.05$} \\
\hline MG & 389056 & $91,9290 \%$ \\
\hline EÉ & 23653 & $116,5676 \%$ \\
\hline ÉB & 7385 & $119,1580 \%$ \\
\hline Sig. & &, 649 \\
\hline
\end{tabular}

Means for groups in homogeneous subsets are displayed.

a. Uses Harmonic Mean Sample Size = 16642,824.

b. The group sizes are unequal. The harmonic mean of the group sizes is used. Type I error levels are not guaranteed. 
Többváltozós (100 \% fölöttiek levágásával)

\begin{tabular}{|c|c|c|c|c|c|c|c|c|}
\hline \multirow[b]{3}{*}{ EltérRA } & \multirow{3}{*}{$\mathrm{N}$} & \multirow{3}{*}{ Mean } & \multicolumn{4}{|c|}{ Descriptives } & \multirow{3}{*}{ Min. } & \multirow{3}{*}{ Max. } \\
\hline & & & \multirow{2}{*}{$\begin{array}{c}\text { Std. } \\
\text { Deviation }\end{array}$} & \multirow{2}{*}{$\begin{array}{l}\text { Std. } \\
\text { Error }\end{array}$} & \multicolumn{2}{|c|}{$\begin{array}{l}\text { 95\% Confidence } \\
\text { Interval for Mean }\end{array}$} & & \\
\hline & & & & & $\begin{array}{l}\text { Lower } \\
\text { Bound }\end{array}$ & $\begin{array}{l}\text { Upper } \\
\text { Bound } \\
\end{array}$ & & \\
\hline $\mathrm{MG}$ & 289874 & $22,2257 \%$ & $33,43134 \%$ & $0,06209 \%$ & $22,1040 \%$ & $22,3474 \%$ & $0,00 \%$ & $100,00 \%$ \\
\hline EÉ & 18896 & $28,5620 \%$ & $28,03837 \%$ & $0,20397 \%$ & $28,1622 \%$ & $28,9618 \%$ & $0,00 \%$ & $100,00 \%$ \\
\hline ÉB & 6089 & $29,5520 \%$ & $26,34143 \%$ & $0,33757 \%$ & $28,8903 \%$ & $30,2138 \%$ & $0,00 \%$ & $100,00 \%$ \\
\hline Total & 314859 & $22,7476 \%$ & $33,05653 \%$ & $0,05891 \%$ & $22,6322 \%$ & $22,8631 \%$ & $0,00 \%$ & $100,00 \%$ \\
\hline
\end{tabular}

Test of Homogeneity of Variances

\begin{tabular}{|r|c|c|c|}
\hline Levene Statistic & df1 & df2 & Sig. \\
\hline 608,198 & & 314856 &, 000 \\
\hline
\end{tabular}

ANOVA

\begin{tabular}{|l|r|r|r|r|r|}
\hline \multicolumn{1}{|c|}{ EltérRA } & Sum of Squares & df & Mean Square & F & \multicolumn{1}{c|}{ Sig. } \\
\hline Between Groups & 999718,160 & 2 & 499859,080 & 458,769 &, 000 \\
Within Groups & 343056408,734 & 314856 & 1089,566 & & \\
Total & 344056126,894 & 314858 & & & \\
\hline
\end{tabular}

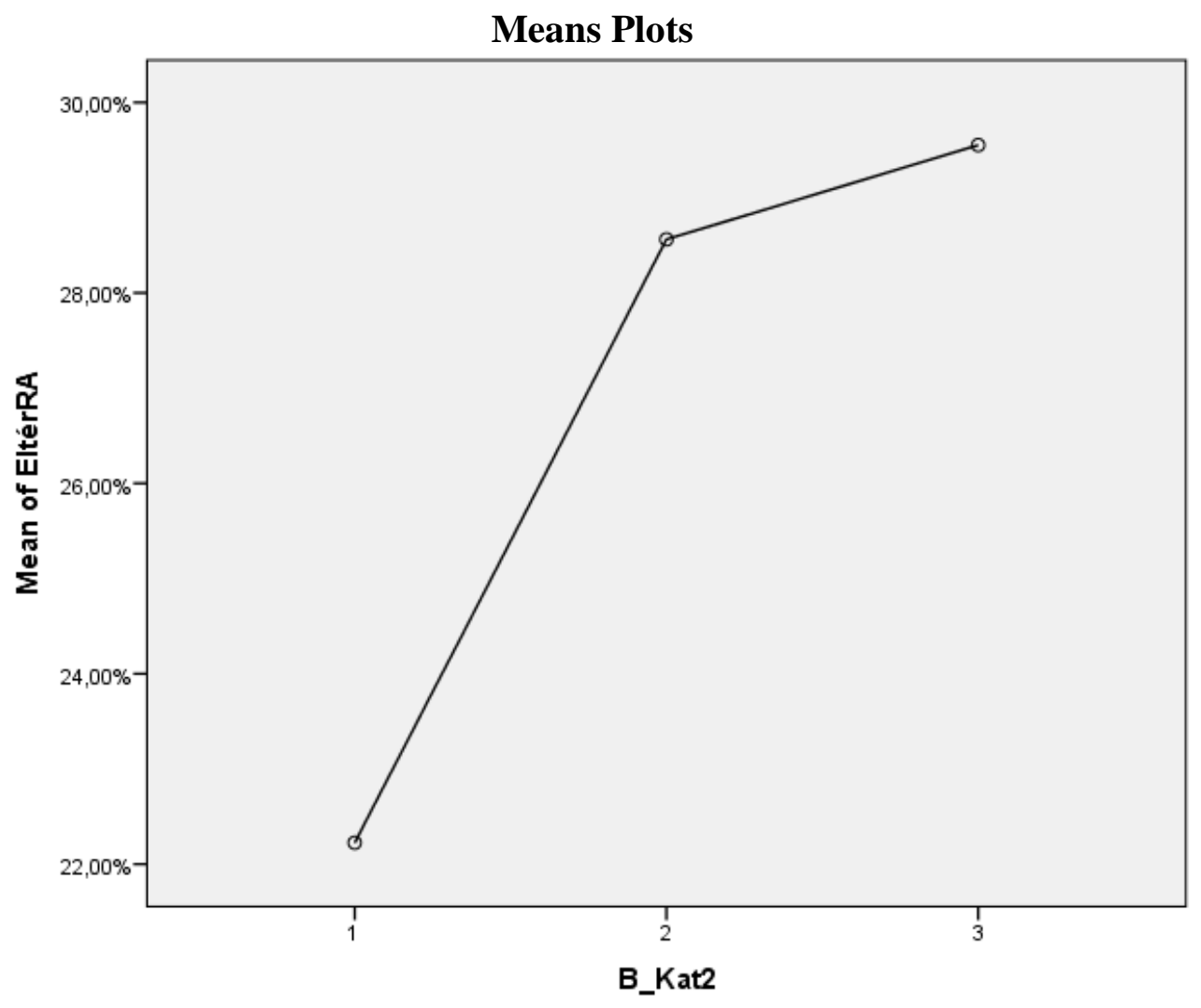




\section{Post Hoc Tests}

Multiple Comparisons (Dependent Variable: EltérRA; Scheffe)

\begin{tabular}{|c|c|c|c|c|c|c|}
\hline \multirow{2}{*}{$\stackrel{(\mathrm{I})}{\text { B_Kat2 }}$} & \multirow{2}{*}{$\begin{array}{c}(\mathrm{J}) \\
\text { B_Kat2 }\end{array}$} & \multirow{2}{*}{$\begin{array}{c}\text { Mean } \\
\text { Difference (I-J) }\end{array}$} & \multirow{2}{*}{$\begin{array}{l}\text { Std. } \\
\text { Error }\end{array}$} & \multirow{2}{*}{ Sig. } & \multicolumn{2}{|c|}{ 95\% Confidence Interval } \\
\hline & & & & & Lower Bound & Upper Bound \\
\hline \multirow{2}{*}{ MG } & EÉ & $-6,33637 \% *$ & $0,24783 \%$ & 000, & $-6,9430 \%$ & $-5,7297 \%$ \\
\hline & ÉB & $-7,32637 \% *$ & $0,42743 \%$ &, 000 & $-8,3726 \%$ & $-6,2801 \%$ \\
\hline \multirow{2}{*}{ EÉ } & MG & $6,33637 \% *$ & $0,24783 \%$ & ,000 & $5,7297 \%$ & $6,9430 \%$ \\
\hline & ÉB & $-0,99000 \%$ & $0,48642 \%$ &, 126 & $-2,1806 \%$ & $0,2006 \%$ \\
\hline \multirow{2}{*}{ ÉB } & MG & $7,32637 \% *$ & $0,42743 \%$ & ,000 & $6,2801 \%$ & $8,3726 \%$ \\
\hline & EÉ & $0,99000 \%$ & $0,48642 \%$ &, 126 & $-0,2006 \%$ & $2,1806 \%$ \\
\hline
\end{tabular}

*. The mean difference is significant at the 0.05 level.

\section{Homogeneous Subsets}

\begin{tabular}{|l|r|r|r|r|}
\multicolumn{5}{|c|}{ Scheffe $^{\text {a,b }}$ (EltérRA) } \\
\cline { 3 - 5 } B_Kat2 & \multicolumn{1}{|c|}{ N } & \multicolumn{3}{|c|}{ Subset for alpha $=0.05$} \\
\hline MG & 289874 & $22,2257 \%$ & 2 & \multicolumn{1}{c|}{3} \\
EÉ & 18896 & & $28,5620 \%$ & \\
ÉB & 6089 & & & $29,5520 \%$ \\
Sig. & & 1,000 & 1,000 & 1,000 \\
\hline
\end{tabular}

Means for groups in homogeneous subsets are displayed.

a. Uses Harmonic Mean Sample Size = 13599,176.

b. The group sizes are unequal. The harmonic mean of the group sizes is used. Type I error levels are not guaranteed. 
Többváltozós (100 \% és afölöttiek levágásával)

Descriptives

\begin{tabular}{|c|c|c|c|c|c|c|c|c|}
\hline \multirow{2}{*}{ EltérRA } & \multirow{2}{*}{$\mathrm{N}$} & \multirow{2}{*}{ Mean } & \multirow{2}{*}{$\begin{array}{c}\text { Std. } \\
\text { Deviation }\end{array}$} & \multirow{2}{*}{$\begin{array}{l}\text { Std. } \\
\text { Error }\end{array}$} & \multicolumn{2}{|c|}{$\begin{array}{l}95 \% \text { Confidence } \\
\text { Interval for Mean }\end{array}$} & \multirow{2}{*}{ Min. } & \multirow{2}{*}{ Max. } \\
\hline & & & & & $\begin{array}{l}\text { Lower } \\
\text { Bound }\end{array}$ & $\begin{array}{l}\text { Upper } \\
\text { Bound }\end{array}$ & & \\
\hline MG & 263061 & $14,2984 \%$ & $23,49870 \%$ & $0,04582 \%$ & $14,2086 \%$ & $14,3882 \%$ & $0,00 \%$ & $100,00 \%$ \\
\hline EÉ & 18650 & $27,6197 \%$ & $26,98728 \%$ & $0,19761 \%$ & $27,2324 \%$ & $28,0071 \%$ & $0,00 \%$ & $100,00 \%$ \\
\hline ÉB & 6051 & $29,1096 \%$ & $25,82366 \%$ & $0,33197 \%$ & $28,4588 \%$ & $29,7604 \%$ & $0,00 \%$ & $100,00 \%$ \\
\hline Total & 287762 & $15,4732 \%$ & $24,09863 \%$ & $0,04492 \%$ & $15,3851 \%$ & $15,5612 \%$ & $0,00 \%$ & $100,00 \%$ \\
\hline
\end{tabular}

Test of Homogeneity of Variances

\begin{tabular}{|r|c|c|c|}
\hline Levene Statistic & df1 & df2 & Sig. \\
\hline 913,555 & & 287759 &, 000 \\
\hline
\end{tabular}

ANOVA

\begin{tabular}{|l|r|r|r|r|r|}
\hline \multicolumn{1}{|c|}{ EltérRA } & Sum of Squares & df & Mean Square & F & \multicolumn{1}{c|}{ Sig. } \\
\hline Between Groups & 4239874,355 & 2 & 2119937,177 & 3745,379 &, 000 \\
Within Groups & 162875632,587 & 287759 & 566,014 & & \\
Total & 167115506,942 & 287761 & & & \\
\hline
\end{tabular}

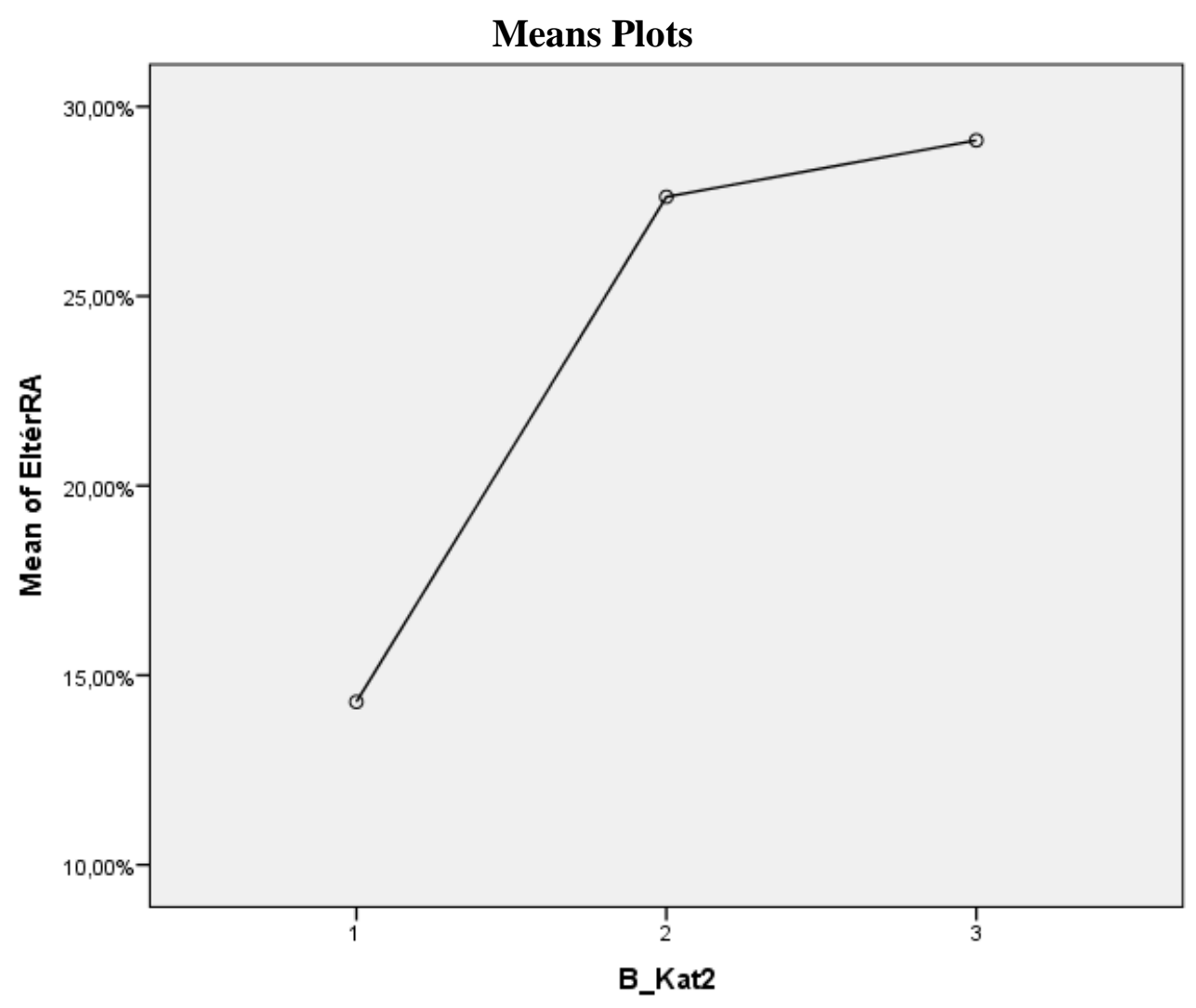




\section{Post Hoc Tests}

Multiple Comparisons (Dependent Variable: EltérRA; Scheffe)

\begin{tabular}{|c|c|c|c|c|c|c|}
\hline \multirow{2}{*}{$\begin{array}{c}(\mathrm{I}) \\
\text { B_Kat2 }\end{array}$} & \multirow{2}{*}{$\begin{array}{c}(\mathrm{J}) \\
\text { B_Kat2 }\end{array}$} & \multirow{2}{*}{$\begin{array}{c}\text { Mean } \\
\text { Difference (I-J) }\end{array}$} & \multirow{2}{*}{$\begin{array}{l}\text { Std. } \\
\text { Error }\end{array}$} & \multirow{2}{*}{ Sig. } & \multicolumn{2}{|c|}{ 95\% Confidence Interval } \\
\hline & & & & & Lower Bound & Upper Bound \\
\hline \multirow{2}{*}{ MG } & $\overline{\mathrm{EE}}$ & $-13,32138 \% *$ & $0,18028 \%$ & , 000 & $-13,7627 \%$ & $-12,8801 \%$ \\
\hline & ÉB & $-14,81126 \% *$ & $0,30934 \%$ & 000 & $-15,5684 \%$ & $-14,0541 \%$ \\
\hline \multirow{2}{*}{ EÉ } & MG & $13,32138 \% *$ & $0,18028 \%$ & 000 & $12,8801 \%$ & $13,7627 \%$ \\
\hline & ÉB & $-1,48988 \% *$ & $0,35198 \%$ &, 000 & $-2,3514 \%$ & $-0,6283 \%$ \\
\hline \multirow{2}{*}{ ÉB } & MG & $14,81126 \% *$ & $0,30934 \%$ & ,000 & $14,0541 \%$ & $15,5684 \%$ \\
\hline & EÉ & $1,48988 \% *$ & $0,35198 \%$ & 000 & $0,6283 \%$ & $2,3514 \%$ \\
\hline
\end{tabular}

*. The mean difference is significant at the 0.05 level.

\section{Homogeneous Subsets}

\begin{tabular}{|l|r|r|r|r|}
\multicolumn{5}{|c|}{ Scheffe $^{\mathrm{a}, \mathrm{b}}$ (EltérRA) } \\
\cline { 3 - 5 } B_Kat2 & \multicolumn{1}{|c|}{$\mathrm{N}$} & \multicolumn{3}{|c|}{ Subset for alpha $=0.05$} \\
\hline MG & 263061 & $14,2984 \%$ & 2 & \multicolumn{1}{c|}{3} \\
EÉ & 18650 & & $27,6197 \%$ & \\
ÉB & 6051 & & & $29,1096 \%$ \\
Sig. & & 1,000 & 1,000 & 1,000 \\
\hline
\end{tabular}

Means for groups in homogeneous subsets are displayed.

a. Uses Harmonic Mean Sample Size = 13472,087.

b. The group sizes are unequal. The harmonic mean of the group sizes is used. Type I error levels are not guaranteed. 


\section{0. melléklet: H4-hez alapstatisztikák}

Gazdálkodók száma és megoszlása az adóalap növelő tétek száma szerint:

\begin{tabular}{|r|r|r|r||r|r|r|r||r|}
\hline \multirow{2}{*}{$\begin{array}{c}\text { Növelö } \\
\text { tételek } \\
\text { száma }\end{array}$} & \multicolumn{4}{|c|}{ Teljes } & \multicolumn{3}{c|}{ Écs egyezőség nélkül } \\
\cline { 2 - 9 } & \multicolumn{1}{|c|}{ MG } & EÉ & \multicolumn{1}{|c|}{ ÉB } & Összesen & \multicolumn{1}{c|}{ MG } & EÉ & \multicolumn{1}{c|}{ ÉB } & Összesen \\
\hline 0 & 146806 & 1204 & 136 & 148146 & 244375 & 3584 & 308 & 248267 \\
\hline 1 & 142015 & 4854 & 444 & 147313 & 91992 & 4959 & 568 & 97519 \\
\hline 2 & 75311 & 7801 & 1270 & 84382 & 38922 & 6759 & 1251 & 46932 \\
\hline 3 & 21433 & 6130 & 1840 & 29403 & 11663 & 5174 & 1786 & 18623 \\
\hline 4 & 3358 & 2641 & 1725 & 7724 & 2132 & 2267 & 1618 & 6017 \\
\hline 5 & 474 & 840 & 1157 & 2471 & 332 & 753 & 1089 & 2174 \\
\hline 6 & 60 & 162 & 561 & 783 & 46 & 142 & 525 & 713 \\
\hline 7 & 7 & 33 & 193 & 233 & 2 & 27 & 182 & 211 \\
\hline 8 & 1 & 2 & 57 & 60 & 1 & 2 & 57 & 60 \\
\hline 9 & & & 8 & 8 & & & 7 & 7 \\
\hline & & & & & & & & 420523 \\
\hline
\end{tabular}

\begin{tabular}{|r|r|r|r||r|r|r|r||r|}
\hline \multirow{2}{*}{$\begin{array}{c}\text { Növelö } \\
\text { tételek } \\
\text { száma }\end{array}$} & \multicolumn{4}{|c|}{ Teljes } & \multicolumn{3}{|c|}{ Écs egyezoség nélkül } \\
\cline { 2 - 9 } & MG & EÉ & \multicolumn{1}{c|}{ ÉB } & Összesen & MG & EÉ & ÉB & Összesen \\
\hline 0 & $37,7 \%$ & $5,1 \%$ & $1,8 \%$ & $35,2 \%$ & $62,7 \%$ & $15,1 \%$ & $4,2 \%$ & $59,0 \%$ \\
\hline 1 & $36,5 \%$ & $20,5 \%$ & $6,0 \%$ & $35,0 \%$ & $23,6 \%$ & $21,0 \%$ & $7,7 \%$ & $23,2 \%$ \\
\hline 2 & $19,3 \%$ & $33,0 \%$ & $17,2 \%$ & $20,1 \%$ & $10,0 \%$ & $28,6 \%$ & $16,9 \%$ & $11,2 \%$ \\
\hline 3 & $5,5 \%$ & $25,9 \%$ & $24,9 \%$ & $7,0 \%$ & $3,0 \%$ & $21,9 \%$ & $24,2 \%$ & $4,4 \%$ \\
\hline 4 & $0,9 \%$ & $11,2 \%$ & $23,3 \%$ & $1,8 \%$ & $0,5 \%$ & $9,6 \%$ & $21,9 \%$ & $1,4 \%$ \\
\hline 5 & $0,1 \%$ & $3,5 \%$ & $15,7 \%$ & $0,6 \%$ & $0,1 \%$ & $3,2 \%$ & $14,7 \%$ & $0,5 \%$ \\
\hline 6 & $0,0 \%$ & $0,7 \%$ & $7,6 \%$ & $0,2 \%$ & $0,0 \%$ & $0,6 \%$ & $7,1 \%$ & $0,2 \%$ \\
\hline 7 & $0,0 \%$ & $0,1 \%$ & $2,6 \%$ & $0,1 \%$ & $0,0 \%$ & $0,1 \%$ & $2,5 \%$ & $0,1 \%$ \\
\hline 8 & $0,0 \%$ & $0,0 \%$ & $0,8 \%$ & $0,0 \%$ & $0,0 \%$ & $0,0 \%$ & $0,8 \%$ & $0,0 \%$ \\
\hline 9 & & - & $0,1 \%$ & $0,0 \%$ & - & - & $0,1 \%$ & $0,0 \%$ \\
\hline Összesen & $100,0 \%$ & $100,0 \%$ & $100,0 \%$ & $100,0 \%$ & $100,0 \%$ & $100,0 \%$ & $100,0 \%$ & $100,0 \%$ \\
\hline
\end{tabular}


Gazdálkodók száma és megoszlása az adóalap csökkentő tétek száma szerint:

\begin{tabular}{|c|c|c|c|c|c|c|c|c|}
\hline \multirow{2}{*}{$\begin{array}{c}\text { Csökkentő } \\
\text { tételek } \\
\text { száma }\end{array}$} & \multicolumn{4}{|c|}{ Teljes } & \multicolumn{4}{|c|}{ Écs egyezőség nélkül } \\
\hline & MG & EÉ & ÉB & Összesen & MG & EÉ & ÉB & Összesen \\
\hline 0 & 156011 & 1286 & 142 & 157439 & 278233 & 5443 & 595 & 284271 \\
\hline 1 & 174146 & 9998 & 1561 & 185705 & 83318 & 7897 & 1470 & 92685 \\
\hline 2 & 49998 & 7624 & 2009 & 59631 & 22453 & 6156 & 1863 & 30472 \\
\hline 3 & 8152 & 3492 & 1816 & 13460 & 4640 & 3017 & 1685 & 9342 \\
\hline 4 & 1005 & 1007 & 1034 & 3046 & 704 & 913 & 966 & 2583 \\
\hline 5 & 135 & 205 & 466 & 806 & 105 & 191 & 457 & 753 \\
\hline 6 & 18 & 40 & 211 & 269 & 12 & 36 & 208 & 256 \\
\hline 7 & & 12 & 90 & 102 & & 12 & 85 & 97 \\
\hline 8 & & 3 & 43 & 46 & & 2 & 43 & 45 \\
\hline 9 & & & 14 & 14 & & & 14 & 14 \\
\hline 10 & & & 3 & 3 & & & 3 & 3 \\
\hline 11 & & & & & & & & \\
\hline 12 & & & 1 & 1 & & & 1 & 1 \\
\hline 13 & & & 1 & 1 & & & 1 & 1 \\
\hline Összesen & 389465 & 23667 & 7 391 & 420523 & 389465 & 23667 & 7 391| & 420523 \\
\hline
\end{tabular}

\begin{tabular}{|c|c|c|c|c|c|c|c|c|}
\hline \multirow{2}{*}{$\begin{array}{c}\text { Csökkentö } \\
\text { tételek } \\
\text { száma } \\
\end{array}$} & \multicolumn{4}{|c|}{ Teljes } & \multicolumn{4}{|c|}{ Écs egyezőség nélkül } \\
\hline & MG & EÉ & ÉB & Összesen & $\mathrm{MG}$ & EÉ & ÉB & Összesen \\
\hline 0 & $40,1 \%$ & $5,4 \%$ & $1,9 \%$ & $37,4 \%$ & $71,4 \%$ & $23,0 \%$ & $8,1 \%$ & $67,6 \%$ \\
\hline 1 & $44,7 \%$ & $42,2 \%$ & $21,1 \%$ & $44,2 \%$ & $21,4 \%$ & $33,4 \%$ & $19,9 \%$ & $22,0 \%$ \\
\hline 2 & $12,8 \%$ & $32,2 \%$ & $27,2 \%$ & $14,2 \%$ & $5,8 \%$ & $26,0 \%$ & $25,2 \%$ & $7,2 \%$ \\
\hline 3 & $2,1 \%$ & $14,8 \%$ & $24,6 \%$ & $3,2 \%$ & $1,2 \%$ & $12,7 \%$ & $22,8 \%$ & $2,2 \%$ \\
\hline 4 & $0,3 \%$ & $4,3 \%$ & $14,0 \%$ & $0,7 \%$ & $0,2 \%$ & $3,9 \%$ & $13,1 \%$ & $0,6 \%$ \\
\hline 5 & $0,0 \%$ & $0,9 \%$ & $6,3 \%$ & $0,2 \%$ & $0,0 \%$ & $0,8 \%$ & $6,2 \%$ & $0,2 \%$ \\
\hline 6 & $0,0 \%$ & $0,2 \%$ & $2,9 \%$ & $0,1 \%$ & $0,0 \%$ & $0,2 \%$ & $2,8 \%$ & $0,1 \%$ \\
\hline 7 & & $0,1 \%$ & $1,2 \%$ & $0,0 \%$ & & $0,1 \%$ & $1,2 \%$ & $0,0 \%$ \\
\hline 8 & - & $0,0 \%$ & $0,6 \%$ & $0,0 \%$ & & $0,0 \%$ & $0,6 \%$ & $0,0 \%$ \\
\hline 9 & & & $0,2 \%$ & $0,0 \%$ & & $0,0 \%$ & $0,2 \%$ & $0,0 \%$ \\
\hline 10 & - & - & $0,0 \%$ & $0,0 \%$ & & & $0,0 \%$ & $0,0 \%$ \\
\hline 11 & & & & & & & & \\
\hline 12 & & & $0,0 \%$ & $0,0 \%$ & & & $0,0 \%$ & $0,0 \%$ \\
\hline 13 & & - & $0,0 \%$ & $0,0 \%$ & & & $0,0 \%$ & $0,0 \%$ \\
\hline Összesen & $100,0 \%$ & $100,0 \%$ & $100,0 \%$ & $100,0 \%$ & $100,0 \%$ & $100,0 \%$ & $100,0 \%$ & $100,0 \%$ \\
\hline
\end{tabular}


Gazdálkodók száma és megoszlása az adóalap módosító tétek összegének száma szerint:

\begin{tabular}{|c|c|c|c|c|c|c|c|c|}
\hline \multirow{2}{*}{$\begin{array}{c}\text { Módosító } \\
\text { tételek } \\
\text { száma }\end{array}$} & \multicolumn{4}{|c|}{ Teljes } & \multicolumn{4}{|c|}{ Écs egyezőség nélkül } \\
\hline & MG & EÉ & ÉB & Összesen & MG & EÉ & ÉB & Összesen \\
\hline & 137176 & 1069 & 116 & 138361 & 214878 & 2682 & 226 & 217786 \\
\hline 1 & 25071 & 251 & 32 & 25354 & 78716 & 2370 & 234 & 81320 \\
\hline 2 & 100775 & 2782 & 229 & 103786 & 43020 & 2822 & 337 & 46179 \\
\hline 3 & 76950 & 5155 & 580 & 82685 & 28403 & 3936 & 557 & 32896 \\
\hline 4 & 34220 & 5624 & 960 & 40804 & 15405 & 4381 & 905 & 20691 \\
\hline 5 & 11000 & 4110 & 1148 & 16258 & 6143 & 3367 & 1088 & 10598 \\
\hline 6 & 3122 & 2493 & 1150 & 6765 & 2050 & 2144 & 1064 & 5258 \\
\hline 7 & 843 & 1301 & 1008 & 3152 & 614 & 1156 & 929 & 2699 \\
\hline 8 & 226 & 566 & 758 & 1550 & 172 & 513 & 702 & 1387 \\
\hline 9 & 62 & 197 & 607 & 866 & 51 & 189 & 575 & 815 \\
\hline 10 & 16 & 74 & 335 & 425 & 10 & 67 & 320 & 397 \\
\hline 11 & 2 & 29 & 217 & 248 & 1 & 25 & 212 & 238 \\
\hline 12 & 2 & 10 & 110 & 122 & 2 & 10 & 104 & 116 \\
\hline 13 & & 4 & 58 & 62 & & 5 & 55 & 60 \\
\hline 14 & & 1 & 36 & 37 & & & 36 & 36 \\
\hline 15 & & 1 & 27 & 28 & & & 27 & 27 \\
\hline 16 & & & 13 & 13 & & & 13 & 13 \\
\hline 17 & & & 4 & 4 & & & 4 & 4 \\
\hline 18 & & & 1 & 1 & & & 1 & 1 \\
\hline 19 & & & & & & & & \\
\hline 20 & & & 1 & 1 & & & 1 & 1 \\
\hline 21 & & & 1 & 1 & & & 1 & 1 \\
\hline Összesen & 389465 & 23667 & 7391 & 420523 & 389465 & 23667 & 7391 & 420523 \\
\hline
\end{tabular}


Kis- és középvállalkozások számviteli beszámolási rendszere

\begin{tabular}{|c|c|c|c|c|c|c|c|c|}
\hline \multirow{2}{*}{$\begin{array}{c}\text { Módosító } \\
\text { tételek } \\
\text { száma }\end{array}$} & \multicolumn{4}{|c|}{ Teljes } & \multicolumn{4}{|c|}{ Écs egyezőség nélkül } \\
\hline & MG & EÉ & ÉB & Összesen & MG & EÉ & ÉB & Összesen \\
\hline 0 & $35,2 \%$ & $4,5 \%$ & $1,6 \%$ & $32,9 \%$ & $55,2 \%$ & $11,3 \%$ & $3,1 \%$ & $51,8 \%$ \\
\hline 1 & $6,4 \%$ & $1,1 \%$ & $0,4 \%$ & $6,0 \%$ & $20,2 \%$ & $10,0 \%$ & $3,2 \%$ & $19,3 \%$ \\
\hline 2 & $25,9 \%$ & $11,8 \%$ & $3,1 \%$ & $24,7 \%$ & $11,0 \%$ & $11,9 \%$ & $4,6 \%$ & $11,0 \%$ \\
\hline 3 & $19,8 \%$ & $21,8 \%$ & $7,8 \%$ & $19,7 \%$ & $7,3 \%$ & $16,6 \%$ & $7,5 \%$ & $7,8 \%$ \\
\hline 4 & $8,8 \%$ & $23,8 \%$ & $13,0 \%$ & $9,7 \%$ & $4,0 \%$ & $18,5 \%$ & $12,2 \%$ & $4,9 \%$ \\
\hline 5 & $2,8 \%$ & $17,4 \%$ & $15,5 \%$ & $3,9 \%$ & $1,6 \%$ & $14,2 \%$ & $14,7 \%$ & $2,5 \%$ \\
\hline 6 & $0,8 \%$ & $10,5 \%$ & $15,6 \%$ & $1,6 \%$ & $0,5 \%$ & $9,1 \%$ & $14,4 \%$ & $1,3 \%$ \\
\hline 7 & $0,2 \%$ & $5,5 \%$ & $13,6 \%$ & $0,7 \%$ & $0,2 \%$ & $4,9 \%$ & $12,6 \%$ & $0,6 \%$ \\
\hline 8 & $0,1 \%$ & $2,4 \%$ & $10,3 \%$ & $0,4 \%$ & $0,0 \%$ & $2,2 \%$ & $9,5 \%$ & $0,3 \%$ \\
\hline 9 & $0,0 \%$ & $0,8 \%$ & $8,2 \%$ & $0,2 \%$ & $0,0 \%$ & $0,8 \%$ & $7,8 \%$ & $0,2 \%$ \\
\hline 10 & $0,0 \%$ & $0,3 \%$ & $4,5 \%$ & $0,1 \%$ & $0,0 \%$ & $0,3 \%$ & $4,3 \%$ & $0,1 \%$ \\
\hline 11 & $0,0 \%$ & $0,1 \%$ & $2,9 \%$ & $0,1 \%$ & $0,0 \%$ & $0,1 \%$ & $2,9 \%$ & $0,1 \%$ \\
\hline 12 & $0,0 \%$ & $0,0 \%$ & $1,5 \%$ & $0,0 \%$ & $0,0 \%$ & $0,0 \%$ & $1,4 \%$ & $0,0 \%$ \\
\hline 13 & - & $0,0 \%$ & $0,8 \%$ & $0,0 \%$ & - & $0,0 \%$ & $0,7 \%$ & $0,0 \%$ \\
\hline 14 & - & $0,0 \%$ & $0,5 \%$ & $0,0 \%$ & - & - & $0,5 \%$ & $0,0 \%$ \\
\hline 15 & - & $0,0 \%$ & $0,4 \%$ & $0,0 \%$ & - & - & $0,4 \%$ & $0,0 \%$ \\
\hline 16 & - & & $0,2 \%$ & $0,0 \%$ & - & _ & $0,2 \%$ & $0,0 \%$ \\
\hline 17 & & & $0,1 \%$ & $0,0 \%$ & - & & $0,1 \%$ & $0,0 \%$ \\
\hline 18 & - & - & $0,0 \%$ & $0,0 \%$ & - & - & $0,0 \%$ & $0,0 \%$ \\
\hline 19 & - & - & - & - & - & - & - & \\
\hline 20 & - & - & $0,0 \%$ & $0,0 \%$ & - & & $0,0 \%$ & $0,0 \%$ \\
\hline 21 & - & - & $0,0 \%$ & $0,0 \%$ & - & - & $0,0 \%$ & $0,0 \%$ \\
\hline Összesen & $100,0 \%$ & $100,0 \%$ & $100,0 \%$ & $100,0 \%$ & $100,0 \%$ & $100,0 \%$ & $100,0 \%$ & $100,0 \%$ \\
\hline
\end{tabular}


Adóalap csökkentő, növelő és módosító tételek alapstatisztikái

\begin{tabular}{|l|r|r|r|r|r|r|}
\hline & \multicolumn{3}{|c|}{ Csökk. (teljes) } & \multicolumn{3}{c|}{ Csökk. (Écs= nélkül) } \\
\hline & MG & \multicolumn{1}{c|}{ EÉ } & \multicolumn{1}{c|}{ ÉB } & \multicolumn{1}{c|}{ MG } & \multicolumn{1}{c|}{ EÉ } & \multicolumn{1}{c|}{ ÉB } \\
\hline Mean &, 78 & 1,74 & 2,69 &, 37 & 1,44 & 2,54 \\
\hline $95 \%$ Confidence &, 78 & 1,72 & 2,66 &, 37 & 1,43 & 2,50 \\
\cline { 2 - 8 } Interval for Mean &, 78 & 1,75 & 2,73 &, 38 & 1,46 & 2,58 \\
\hline $5 \%$ Trimmed Mean &, 72 & 1,69 & 2,59 &, 29 & 1,37 & 2,45 \\
\hline Median & 1,00 & 2,00 & 2,00 & 0,00 & 1,00 & 2,00 \\
\hline Variance &, 594 & 1,011 & 2,298 &, 449 & 1,339 & 2,634 \\
\hline Std. Deviation &, 771 & 1,005 & 1,516 &, 670 & 1,157 & 1,623 \\
\hline Minimum & 0 & 0 & 0 & 0 & 0 & 0 \\
\hline Maximum & 6 & 8 & 13 & 6 & 8 & 13 \\
\hline Range & 6 & 8 & 13 & 6 & 8 & 13 \\
\hline Interquartile Range & 1 & 1 & 2 & 1 & 1 & 2 \\
\hline Skewness &, 868 &, 863 &, 965 & 1,987 &, 686 &, 784 \\
\hline Kurtosis &, 873 & 1,144 & 1,528 & 4,365 &, 354 & 1,095 \\
\hline
\end{tabular}

\begin{tabular}{|l|r|r|r|r|r|r|}
\hline & \multicolumn{3}{|c|}{ Növ. (teljes) } & \multicolumn{3}{c|}{ Növ. (Écs= nélkül) } \\
\hline & MG & \multicolumn{1}{|c|}{ EÉ } & \multicolumn{1}{c|}{ ÉB } & MG & \multicolumn{1}{c|}{ EÉ } & \multicolumn{1}{c|}{ ÉB } \\
\hline Mean & 0,96 & 2,32 & 3,58 & 0,55 & 2,02 & 3,42 \\
\hline 95\% Confidence & 0,96 & 2,3 & 3,54 & 0,55 & 2,01 & 3,38 \\
\cline { 2 - 7 } Interval for Mean & 0,96 & 2,33 & 3,61 & 0,56 & 2,04 & 3,46 \\
\hline 5\% Trimmed Mean & 0,89 & 2,29 & 3,56 & 0,45 & 1,97 & 3,41 \\
\hline Median & 1 & 2 & 4 & 0 & 2 & 3 \\
\hline Variance & 0,89 & 1,481 & 2,438 & 0,713 & 1,83 & 2,743 \\
\hline Std. Deviation & 0,944 & 1,217 & 1,561 & 0,845 & 1,353 & 1,656 \\
\hline Minimum & 0 & 0 & 0 & 0 & 0 & 0 \\
\hline Maximum & 8 & 8 & 9 & 8 & 8 & 9 \\
\hline Range & 8 & 8 & 9 & 8 & 8 & 9 \\
\hline Interquartile Range & 2 & 2 & 3 & 1 & 2 & 3 \\
\hline Skewness & 0,837 & 0,383 & 0,223 & 1,622 & 0,339 & 0,134 \\
\hline Kurtosis & 0,399 & 0,147 & $-0,055$ & 2,516 & $-0,243$ & $-0,144$ \\
\hline
\end{tabular}




\begin{tabular}{|l|r|r|r|r|r|r|}
\hline & \multicolumn{3}{|c|}{ Össz. (teljes) } & \multicolumn{3}{c|}{ Össz. (Écs= nélkül) } \\
\hline & MG & EÉ & ÉB & MG & \multicolumn{1}{c|}{ EÉ } & \multicolumn{1}{c|}{ ÉB } \\
\hline Mean & 1,74 & 4,05 & 6,27 & 0,93 & 3,47 & 5,96 \\
\hline 95\% Confidence & 1,73 & 4,03 & 6,21 & 0,92 & 3,44 & 5,89 \\
\cline { 2 - 7 } Interval for Mean & 1,74 & 4,08 & 6,33 & 0,93 & 3,5 & 6,03 \\
\hline 5\% Trimmed Mean & 1,65 & 4,05 & 6,2 & 0,77 & 3,4 & 5,91 \\
\hline Median & 2 & 4 & 6 & 0 & 4 & 6 \\
\hline Variance & 2,422 & 3,407 & 7,068 & 1,778 & 4,763 & 8,349 \\
\hline Std. Deviation & 1,556 & 1,846 & 2,659 & 1,333 & 2,182 & 2,889 \\
\hline Minimum & 0 & 0 & 0 & 0 & 0 & 0 \\
\hline Maximum & 12 & 15 & 21 & 12 & 13 & 21 \\
\hline Range & 12 & 15 & 21 & 12 & 13 & 21 \\
\hline Interquartile Range & 3 & 2 & 4 & 1 & 3 & 4 \\
\hline Skewness & 0,452 & 0,273 & 0,498 & 1,627 & 0,25 & 0,331 \\
\hline Kurtosis & $-0,415$ & 0,672 & 0,747 & 2,486 & $-0,269$ & 0,414 \\
\hline
\end{tabular}


Adóalap csökkentő, növelö és módosító tételek M-Esztimátorai

M-Estimators ${ }^{\mathrm{e}}$

\begin{tabular}{|c|c|c|c|c|c|}
\hline & B_Kat & $\begin{array}{c}\text { Huber's } \\
\text { M-Estimator }^{\mathrm{a}}\end{array}$ & $\begin{array}{c}\text { Tukey's } \\
\text { Biweight }^{\text {b }}\end{array}$ & $\begin{array}{c}\text { Hampel's } \\
\text { M-Estimator }\end{array}$ & $\begin{array}{l}\text { Andrews' } \\
\text { Wave }^{\mathrm{d}}\end{array}$ \\
\hline \multirow{3}{*}{$\begin{array}{l}\text { Csökk. } \\
\text { (teljes) }\end{array}$} & MG &, 75 & ,74 & ,76 & ,74 \\
\hline & EÉ & 1,69 & 1,66 & 1,69 & 1,66 \\
\hline & ÉB & 2,53 & 2,46 & 2,53 & 2,46 \\
\hline \multirow{3}{*}{$\begin{array}{l}\text { Csökk. } \\
\text { (Écs= } \\
\text { nélkül) }\end{array}$} & MG & & & & \\
\hline & EÉ & 1,32 & 1,35 & 1,39 & 1,35 \\
\hline & ÉB & 2,36 & 2,31 & 2,40 & 2,31 \\
\hline \multirow{3}{*}{$\begin{array}{l}\text { Növ. } \\
\text { (teljes) }\end{array}$} & MG & ,90 &, 89 & ,92 & ,89 \\
\hline & EÉ & 2,24 & 2,25 & 2,29 & 2,25 \\
\hline & ÉB & 3,54 & 3,51 & 3,53 & 3,51 \\
\hline \multirow{3}{*}{$\begin{array}{l}\text { Növ. } \\
\text { (Écs= } \\
\text { nélkül) }\end{array}$} & $\mathrm{MG}$ & & & & \\
\hline & EÉ & 1,98 & 1,95 & 1,97 & 1,95 \\
\hline & ÉB & 3,36 & 3,37 & 3,40 & 3,37 \\
\hline \multirow{3}{*}{$\begin{array}{l}\text { Össz. } \\
\text { (teljes) }\end{array}$} & $\mathrm{MG}$ & 1,68 & 1,59 & 1,59 & 1,59 \\
\hline & EÉ & 3,99 & 3,97 & 3,99 & 3,98 \\
\hline & ÉB & 6,12 & 6,08 & 6,15 & 6,08 \\
\hline \multirow{3}{*}{$\begin{array}{l}\text { Össz. } \\
\text { (Écs= } \\
\text { nélkül) }\end{array}$} & $\mathrm{MG}$ & & & & \\
\hline & EÉ & 3,43 & 3,41 & 3,40 & 3,41 \\
\hline & ÉB & 5,89 & 5,83 & 5,89 & 5,83 \\
\hline
\end{tabular}

a. The weighting constant is 1,339 .

b. The weighting constant is 4,685 .

c. The weighting constants are $1,700,3,400$, and 8,500

d. The weighting constant is $1,340 *$ pi.

e. Some M-Estimators cannot be computed because of the highly centralized distribution around the median. 
Adóalap módosító tételek Hisztogramjai
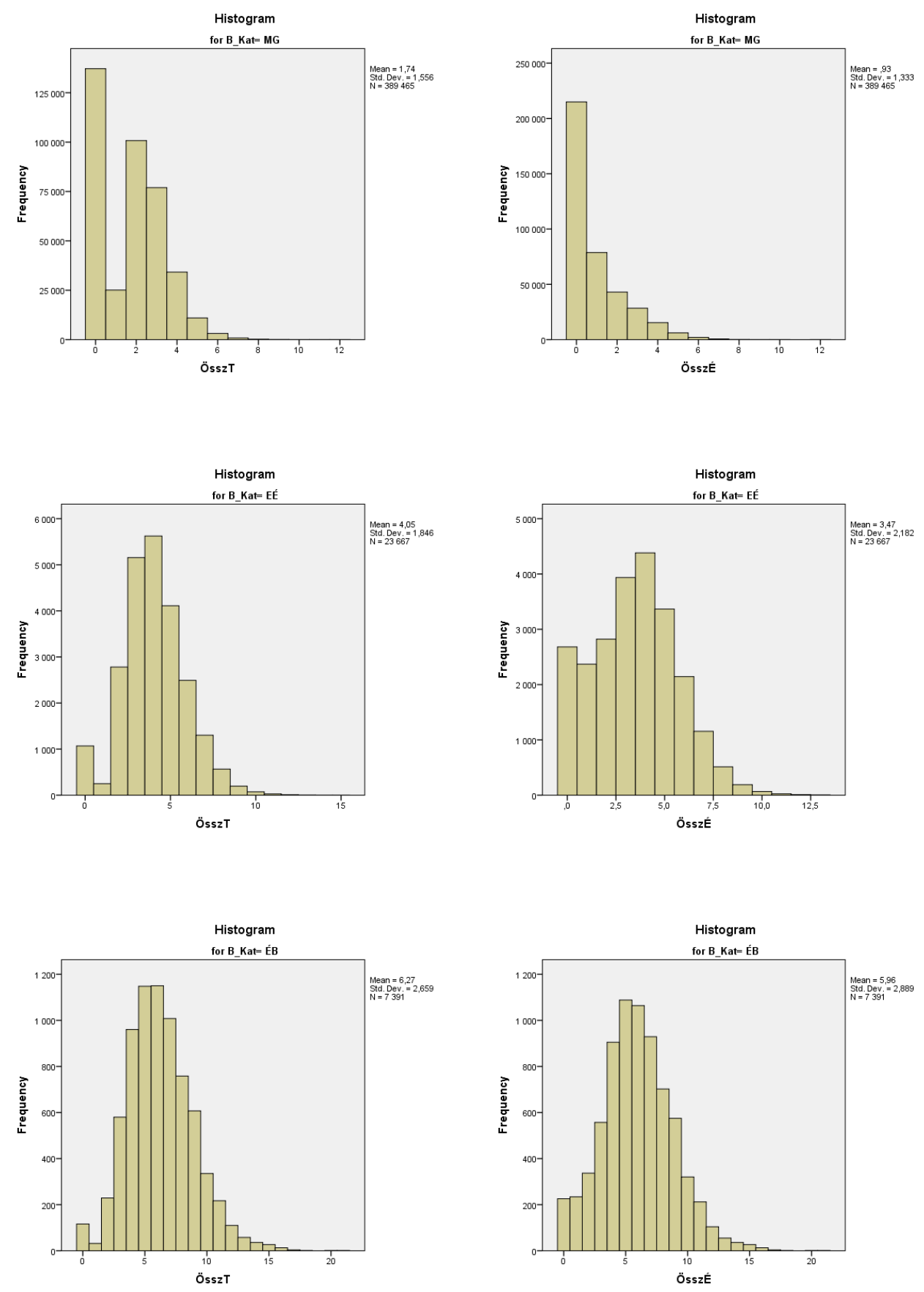
Adóalap módosító tételek doboz ábrái (Box plot)
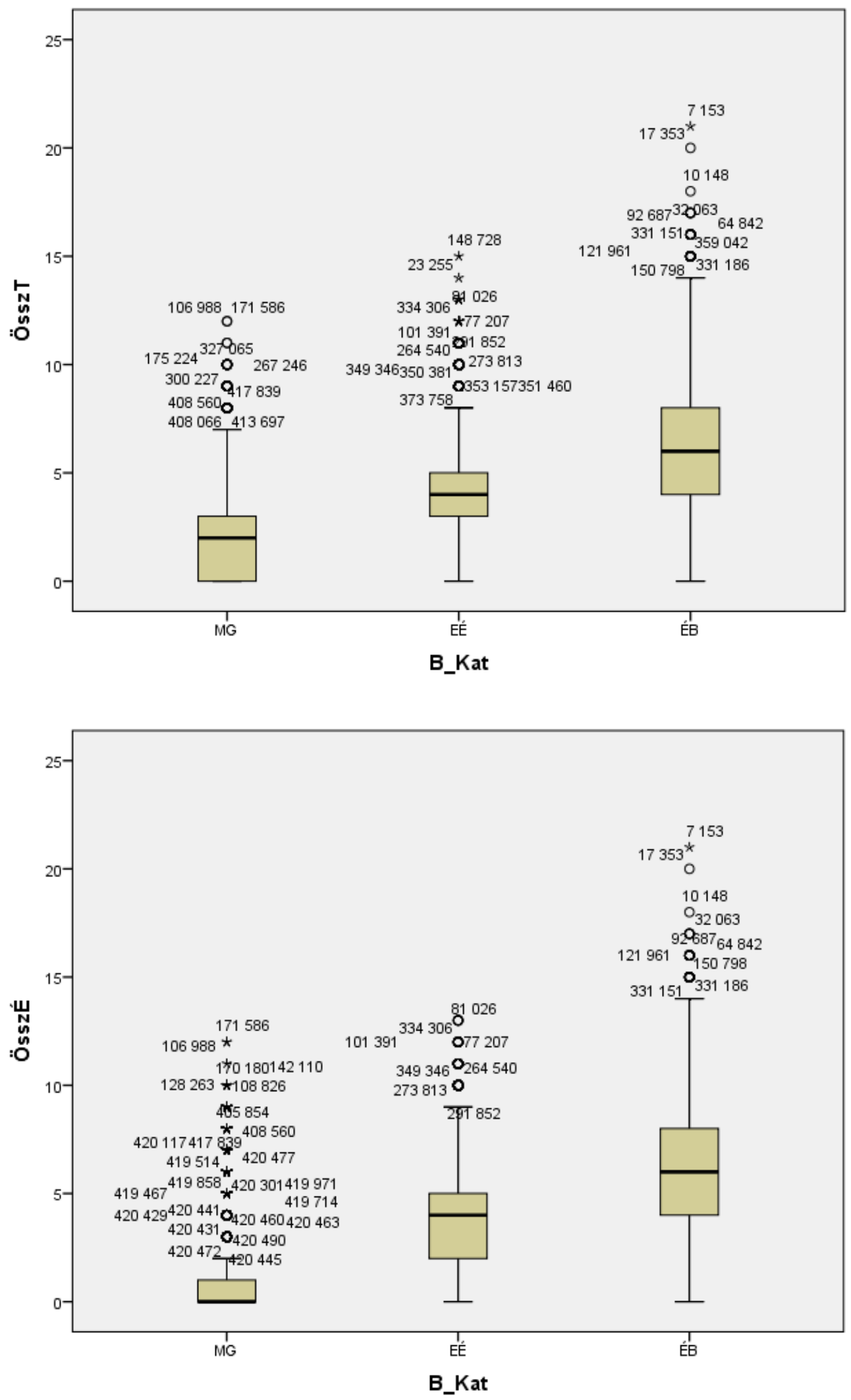


\section{1. melléklet: H4-hez varianciaanalízis}

\section{Descriptives}

\begin{tabular}{|l|r|r|r|r|r|r|r|r|}
\hline \multirow{2}{*}{ ÖsszT } & \multirow{2}{*}{$\mathrm{N}$} & \multirow{2}{*}{ Mean } & \multirow{2}{*}{$\begin{array}{c}\text { Std. } \\
\text { Deviation }\end{array}$} & $\begin{array}{c}\text { Std. } \\
\text { Error }\end{array}$ & \multicolumn{2}{|c|}{$\begin{array}{c}\text { 95\% Confidence } \\
\text { Interval for Mean }\end{array}$} & \multirow{2}{*}{ Min. } & \multirow{2}{*}{ Max. } \\
\cline { 6 - 7 } & & & & & Lower Bound & Upper Bound & & \\
\hline MG & 389465 & 1,74 & 1,556 &, 002 & 1,73 & 1,74 & 0 & 12 \\
EÉ & 23667 & 4,05 & 1,846 &, 012 & 4,03 & 4,08 & 0 & 15 \\
ÉB & 7391 & 6,27 & 2,659 &, 031 & 6,21 & 6,33 & 0 & 21 \\
Total & 420523 & 1,95 & 1,783 &, 003 & 1,94 & 1,95 & 0 & 21 \\
\hline
\end{tabular}

Test of Homogeneity of Variances

\begin{tabular}{|c|c|c|c|}
\hline Levene Statistic & df1 & df2 & Sig. \\
\hline 2892,876 & 2 & 420520 &, 000 \\
\hline
\end{tabular}

ANOVA

\begin{tabular}{|l|r|r|r|r|r|}
\hline \multicolumn{1}{|c|}{ ÖsszT } & Sum of Squares & df & Mean Square & F & Sig. \\
\hline Between Groups & 260426,856 & 2 & 130213,428 & 50883,289 &, 000 \\
Within Groups & 1076136,231 & 420520 & 2,559 & & \\
Total & 1336563,086 & 420522 & & & \\
\hline
\end{tabular}

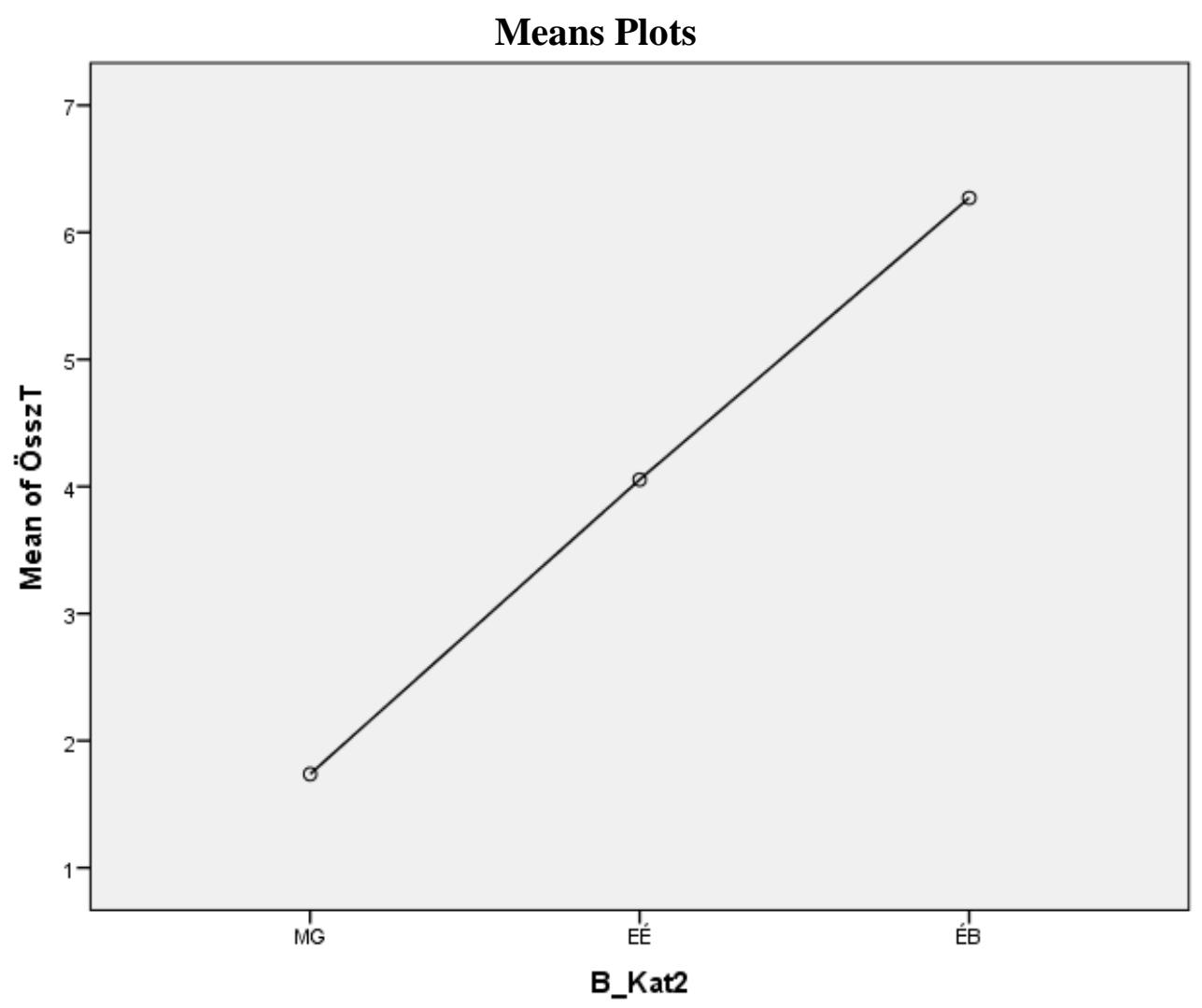




\section{Post Hoc Tests}

Multiple Comparisons (Dependent Variable: ÖsszT; Scheffe)

\begin{tabular}{|l|l|r|r|r|r|r|}
\hline \multirow{2}{*}{ B_I } & & \multicolumn{1}{c|}{$(\mathrm{J})$} & \multicolumn{1}{c|}{ Mean } & \multicolumn{1}{c|}{ Std. } & \multirow{2}{*}{ Sig. } & \multicolumn{2}{|c|}{ 95\% Confidence Interval } \\
\cline { 6 - 7 } B_Kat2 & B_Kat2 & Difference (I-J) & Error & & Lower Bound & Upper Bound \\
\hline \multirow{2}{*}{ MG } & EÉ & $-2,317 *$ &, 011 &, 000 & $-2,34$ & $-2,29$ \\
& ÉB & $-4,534 *$ &, 019 &, 000 & $-4,58$ & $-4,49$ \\
\hline \multirow{2}{*}{ É́ } & MG & $2,317 *$ &, 011 &, 000 & 2,29 & 2,34 \\
& ÉB & $-2,217 *$ &, 021 &, 000 & $-2,27$ & $-2,16$ \\
\hline \multirow{2}{*}{ ÉB } & MG & $4,534 *$ &, 019 &, 000 & 4,49 & 4,58 \\
& EÉ & $2,217 *$ &, 021 &, 000 & 2,16 & 2,27 \\
\hline
\end{tabular}

$*$. The mean difference is significant at the 0.05 level.

\section{Homogeneous Subsets}

\begin{tabular}{|l|r|r|r|r|}
\multicolumn{5}{|c|}{ Scheffe $^{\mathrm{a}, \mathrm{b}}$ (ÖsszT) } \\
\cline { 3 - 5 } B_Kat2 & \multicolumn{2}{|c|}{ N } & \multicolumn{3}{|c|}{ Subset for alpha $=0.05$} \\
\hline MG & 389465 & 1,74 & 2 & \multicolumn{1}{|c|}{3} \\
EÉ & 23667 & & 4,05 & \\
ÉB & 7391 & & & 6,27 \\
Sig. & & 1,000 & 1,000 & 1,000 \\
\hline
\end{tabular}

Means for groups in homogeneous subsets are displayed.

a. Uses Harmonic Mean Sample Size = 16655,541.

b. The group sizes are unequal. The harmonic mean of the group sizes is used. Type I error levels are not guaranteed. 


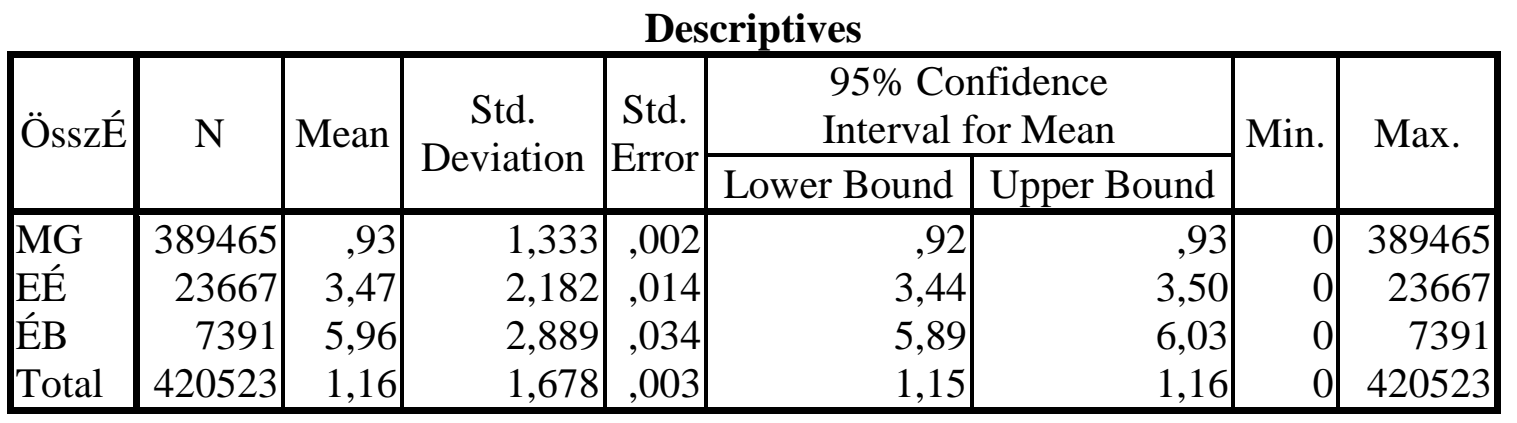

Test of Homogeneity of Variances

\begin{tabular}{|c|c|c|c|}
\hline Levene Statistic & df1 & df 2 & Sig. \\
\hline 14037,009 & 2 & 420520 &, 000 \\
\hline
\end{tabular}

ANOVA

\begin{tabular}{|l|r|r|r|r|r|}
\hline Össz. (écs= nélkül) & Sum of Squares & df & Mean Square & F & \multicolumn{1}{c|}{ Sig. } \\
\hline Between Groups & 317609,435 & 2 & 158804,717 & 77028,063 &, 000 \\
Within Groups & 866964,031 & 420520 & 2,062 & & \\
Total & 1184573,466 & 420522 & & & \\
\hline
\end{tabular}

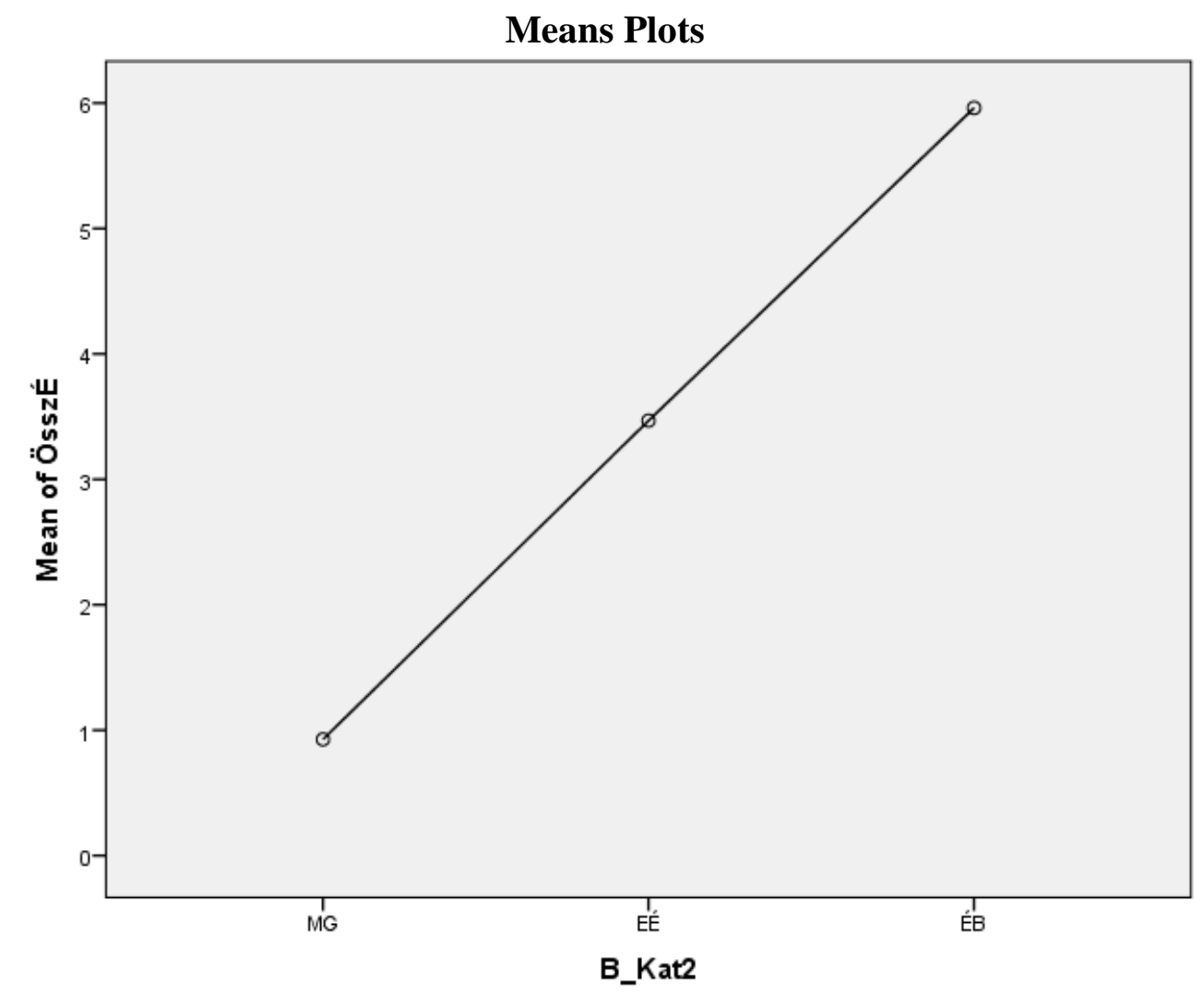




\section{Post Hoc Tests}

Multiple Comparisons (Dependent Variable: ÖsszÉ; Scheffe)

\begin{tabular}{|l|l|r|r|r|r|r|}
\hline \multirow{2}{*}{ B_I } & & $(\mathrm{J})$ & \multicolumn{1}{c|}{ Mean } & \multicolumn{1}{c|}{ Std. } & \multirow{2}{*}{ Sig. } & \multicolumn{2}{|c|}{ 95\% Confidence Interval } \\
\cline { 6 - 8 } Bat2 & B_Kat2 & Difference (I-J) & Error & & Lower Bound & Upper Bound \\
\hline \multirow{2}{*}{ MG } & EÉ & $-2,541 *$ &, 010 &, 000 & $-2,56$ & $-2,52$ \\
& ÉB & $-5,034 *$ &, 017 &, 000 & $-5,08$ & $-4,99$ \\
\hline \multirow{2}{*}{ É́ } & MG & $2,541 *$ &, 010 &, 000 & 2,52 & 2,56 \\
& ÉB & $-2,493 *$ &, 019 &, 000 & $-2,54$ & $-2,45$ \\
\hline \multirow{2}{*}{ ÉB } & MG & $5,034 *$ &, 017 &, 000 & 4,99 & 5,08 \\
& É́ & $2,493 *$ &, 019 &, 000 & 2,45 & 2,54 \\
\hline
\end{tabular}

*. The mean difference is significant at the 0.05 level.

\section{Homogeneous Subsets}

Scheffe (ÖsszÉ)

\begin{tabular}{|l|r|r|r|r|}
\hline \multirow{2}{*}{ B_Kat2 } & \multirow{2}{*}{$\mathrm{N}$} & \multicolumn{3}{|c|}{ Subset for alpha $=0.05$} \\
\cline { 3 - 5 } & & 1 & 2 & \multicolumn{1}{|c|}{3} \\
\hline MG & 389465 &, 93 & & \\
EÉ & 23667 & & 3,47 & 5,96 \\
ÉB & 7391 & & & 1,000 \\
Sig. & & 1,000 & 1,000 & \\
\hline
\end{tabular}

Means for groups in homogeneous subsets are displayed.

a. Uses Harmonic Mean Sample Size $=16655,541$.

b. The group sizes are unequal. The harmonic mean of the group sizes is used. Type I error levels are not guaranteed. 


\section{2. melléklet: Kisvállalkozások határértékeinek klaszter elemzése}

\section{Cluster}

Case Processing Summary ${ }^{a, b}$

\begin{tabular}{|c|c|c|c|c|c|}
\hline \multicolumn{6}{|c|}{ Cases } \\
\hline $\mathrm{Va}$ & & Mis & & Tot & \\
\hline $\mathrm{N}$ & Percent & $\mathrm{N}$ & Percent & $\mathrm{N}$ & Percent \\
\hline 11 & 100,0 & 0 &, 0 & 11 & 100,0 \\
\hline
\end{tabular}

a. Squared Euclidean Distance used

b. Average Linkage (Between Groups)

Proximity Matrix

\begin{tabular}{|l|r|r|r|r|r|r|r|r|r|r|r|}
\hline Case & \multicolumn{10}{|c|}{ Squared Euclidean Distance } \\
\cline { 2 - 10 } & 1:AT & 2:BE & 3:DK & $4:$ DE & $5:$ NL & 6:NO & 7:SI & 8:ES & 9:SE & 10:UK & 11:EU \\
\hline 1:AT &, 000 &, 177 &, 000 &, 000 &, 024 &, 216 &, 177 & 2,483 &, 749 &, 201 &, 088 \\
2:BE &, 177 &, 000 &, 176 &, 177 &, 070 &, 002 &, 000 & 1,518 &, 198 &, 001 &, 015 \\
3:DK &, 000 &, 176 &, 000 &, 000 &, 024 &, 216 &, 176 & 2,482 &, 748 &, 201 &, 088 \\
4:DE &, 000 &, 177 &, 000 &, 000 &, 024 &, 216 &, 177 & 2,483 &, 749 &, 201 &, 088 \\
5:NL &, 024 &, 070 &, 024 &, 024 &, 000 &, 096 &, 070 & 2,085 &, 504 &, 086 &, 020 \\
6:NO &, 216 &, 002 &, 216 &, 216 &, 096 &, 000 &, 002 & 1,437 &, 160 &, 000 &, 028 \\
7:SI &, 177 &, 000 &, 176 &, 177 &, 070 &, 002 &, 000 & 1,518 &, 198 &, 001 &, 015 \\
8:ES & 2,483 & 1,518 & 2,482 & 2,483 & 2,085 & 1,437 & 1,518 &, 000 &, 882 & 1,466 & 1,765 \\
9:SE &, 749 &, 198 &, 748 &, 749 &, 504 &, 160 &, 198 &, 882 &, 000 &, 174 &, 323 \\
10:UK &, 201 &, 001 &, 201 &, 201 &, 086 &, 000 &, 001 & 1,466 &, 174 &, 000 &, 023 \\
11:EU &, 088 &, 015 &, 088 &, 088 &, 020 &, 028 &, 015 & 1,765 &, 323 &, 023 &, 000 \\
\hline
\end{tabular}

This is a dissimilarity matrix

\section{Average Linkage (Between Groups)}

Agglomeration Schedule

\begin{tabular}{|l|r|r|r|r|r|r|}
\hline Stage & \multicolumn{2}{|c|}{ Cluster Combined } & Coefficients & \multicolumn{2}{|c|}{ Stage Cluster First Appears } & Next Stage \\
\cline { 2 - 3 } & Cluster 1 & Cluster 2 & & Cluster 1 & Cluster 2 & \\
\hline 1 & 2 & 7 &, 000 & 0 & 0 & 5 \\
2 & 1 & 4 &, 000 & 0 & 0 & 3 \\
3 & 1 & 3 &, 000 & 2 & 0 & 8 \\
4 & 6 & 10 &, 000 & 0 & 0 & 5 \\
5 & 2 & 6 &, 001 & 1 & 4 & 7 \\
6 & 5 & 11 &, 020 & 0 & 0 & 7 \\
7 & 2 & 5 &, 051 & 5 & 6 & 8 \\
8 & 1 & 2 &, 147 & 3 & 7 & 9 \\
9 & 1 & 9 &, 422 & 8 & 0 & 10 \\
10 & 1 & 8 & 1,812 & 9 & 0 & 0 \\
\hline
\end{tabular}




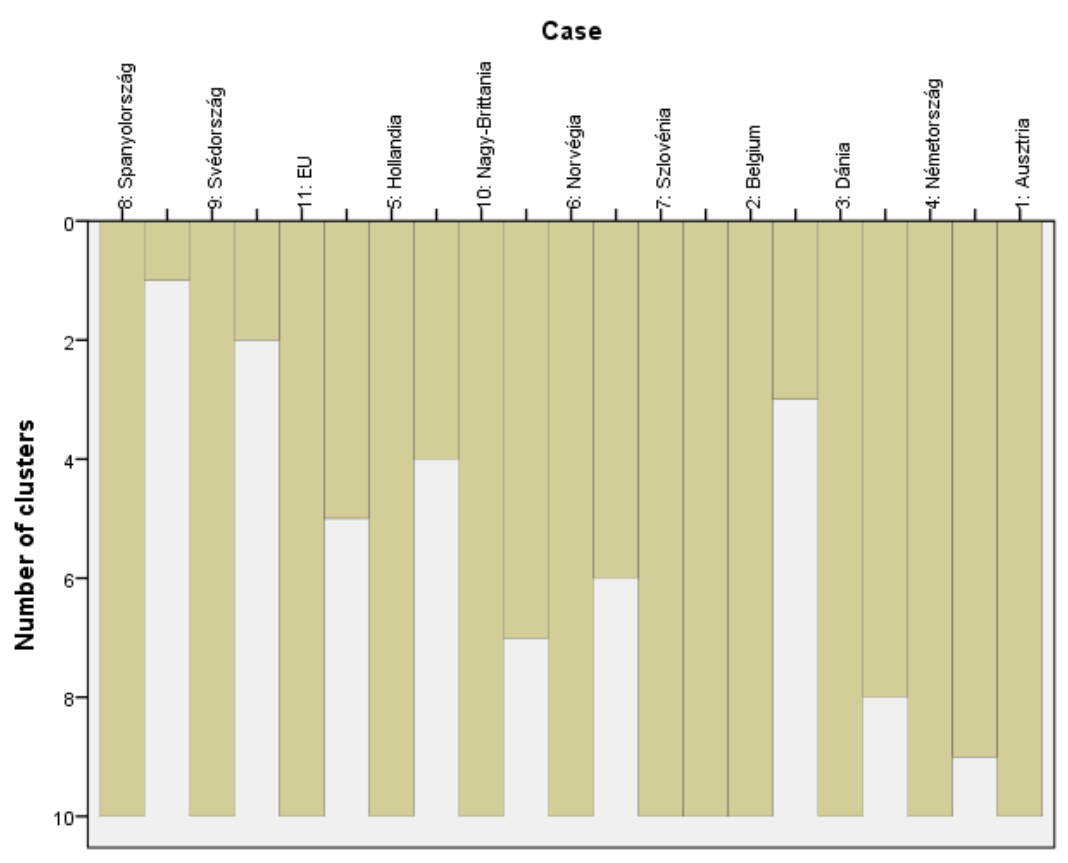




\section{3. melléklet: Közepes vállalkozások határértékeinek klaszter elemzése}

\section{Cluster}

Case Processing Summary ${ }^{\mathrm{a}}$

\begin{tabular}{|c|c|c|c|c|c|}
\hline \multicolumn{6}{|c|}{ Cases } \\
\hline $\mathrm{Va}$ & & Mis & & Tot & \\
\hline $\mathrm{N}$ & Percent & $\mathrm{N}$ & Percent & $\mathrm{N}$ & Percent \\
\hline 8 & 100,0 & 0 & , & 8 & 100,0 \\
\hline
\end{tabular}

a. Average Linkage (Between Groups)

Proximity Matrix

\begin{tabular}{|c|c|c|c|c|c|c|c|c|}
\hline \multirow[t]{2}{*}{ Case } & \multicolumn{8}{|c|}{ Squared Euclidean Distance } \\
\hline & 1:AT & 2:DK & 3:DE & $4: \mathrm{NL}$ & 5:SI & 6:ES & 7:UK & 8:EU \\
\hline 1:AT &, 000 &, 000 &, 000 &, 015 &, 108 & 1,983 & ,164 &, 003 \\
\hline :DK &, 000 &, 000 &, 000 &, 015 &, 107 & 1,978 & , 163 & ,003 \\
\hline $3: \mathrm{DE}$ & ,000 & ,000 & ,000 &, 015 &, 108 & 1,983 & , 164 & ,003 \\
\hline $4: \mathrm{NL}$ & ,015 & ,015 & ,015, & ,000 &, 042 & 1,711 & 080, & 031, \\
\hline 5:SI & , 108 &, 107 & , 108 & ,042 &, 000 & 1,329 & ,008 & , 146 \\
\hline $6: \mathrm{ES}$ & 1,983 & 1,978 & 1,983 & 1,711 & 1,329 &, 000 & 1,213 & 2,108 \\
\hline 7:UK &, 164 &, 163 &, 164 &, 080 &, 008 & 1,213 & ,000 &, 210 \\
\hline 8:EU & ,003 & ,003 & ,003 & ,031 & , 146 & 2,108 & ,210 & ,000 \\
\hline
\end{tabular}

This is a dissimilarity matrix

\section{Average Linkage (Between Groups)}

Agglomeration Schedule

\begin{tabular}{|l|r|r|r|r|r|r|}
\hline \multirow{2}{*}{ Stage } & \multicolumn{2}{|c|}{ Cluster Combined } & Coefficients & \multicolumn{2}{|c|}{ Stage Cluster First Appears } & Next Stage \\
\cline { 2 - 3 } \cline { 5 - 6 } & Cluster 1 & Cluster 2 & & Cluster 1 & Cluster 2 & \\
\hline 1 & 1 & 3 &, 000 & 0 & 0 & 2 \\
2 & 1 & 2 &, 000 & 1 & 0 & 3 \\
3 & 1 & 8 &, 003 & 2 & 0 & 5 \\
4 & 5 & 7 &, 008 & 0 & 0 & 6 \\
5 & 1 & 4 &, 019 & 3 & 0 & 6 \\
6 & 1 & 5 &, 129 & 5 & 4 & 7 \\
7 & 1 & 6 & 1,758 & 6 & 0 & 0 \\
\hline
\end{tabular}




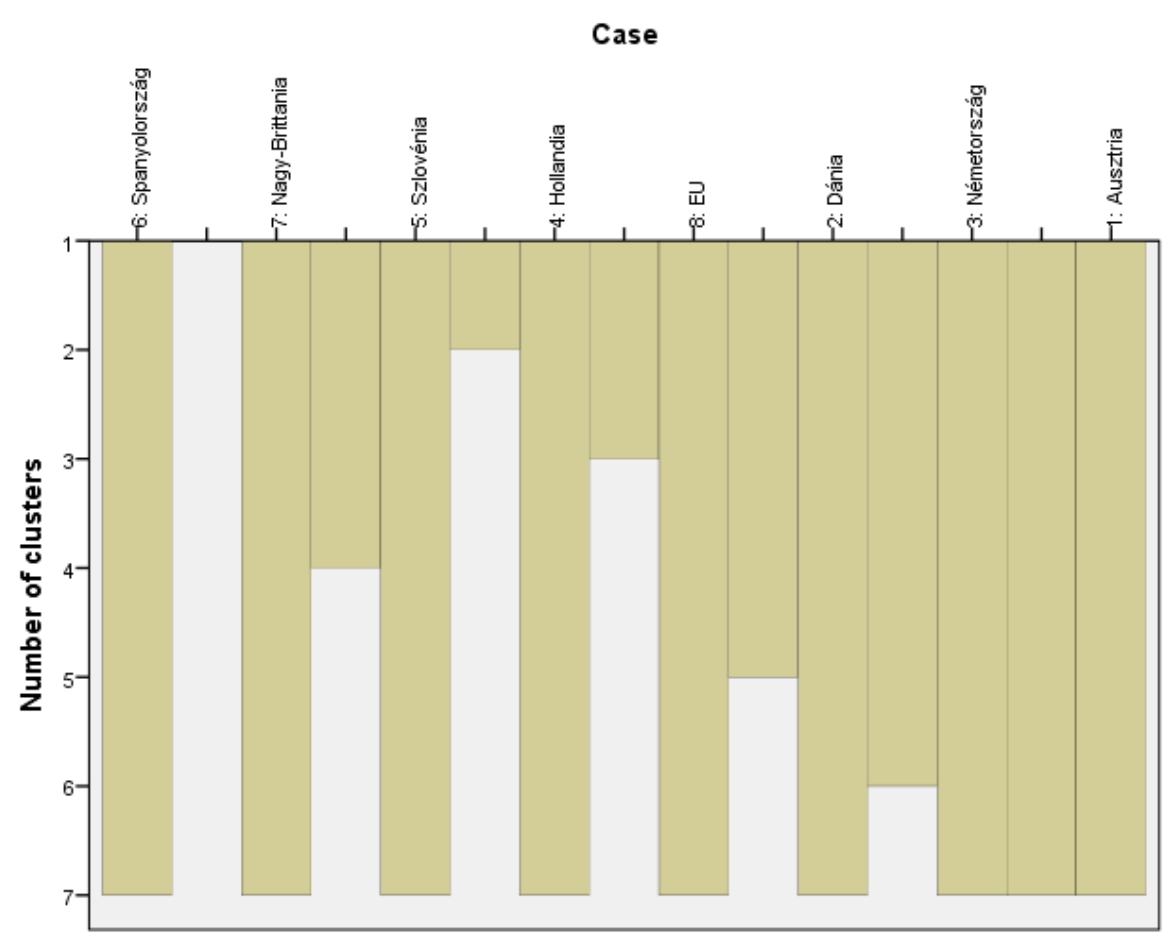




\section{4. melléklet: Beszámoló határértékeinek klaszter elemzése}

\section{Cluster}

\section{Case Processing Summary ${ }^{\mathrm{a}}$}

\begin{tabular}{|c|c|c|c|c|c|}
\hline \multicolumn{6}{|c|}{ Cases } \\
\hline $\mathrm{Va}$ & & Mis & & Tot & \\
\hline $\mathrm{N}$ & Percent & \begin{tabular}{l|l}
$\mathrm{N}$ \\
\end{tabular} & Percent & $\mathrm{N}$ & Percent \\
\hline 13 & 100,0 & 0 & , & 13 & 100,0 \\
\hline
\end{tabular}

a. Average Linkage (Between Groups)

Proximity Matrix

\begin{tabular}{|l|r|r|r|r|r|r|r|r|r|r|r|r|r|r|}
\hline Case & \multicolumn{10}{|c|}{ Squared Euclidean Distance } \\
\cline { 2 - 10 } & $1: \mathrm{FR}$ & $2: \mathrm{DK}$ & $3: \mathrm{PT}$ & $4: \mathrm{ES}$ & $5: \mathrm{LT}$ & $6: \mathrm{HU}$ & $7: \mathrm{PL}$ & $8: \mathrm{NO}$ & $9: \mathrm{RO}$ & $10: \mathrm{EU}$ & $11: \mathrm{NL}$ & $12: \mathrm{IT}$ & $13: \mathrm{AT}$ \\
\hline 1:FR &, 000 &, 015 &, 047 &, 067 &, 232 &, 885 & 1,015 & 1,966 & 2,071 & 2,382 & 2,775 & 2,775 & 3,254 \\
2:DK &, 015 &, 000 &, 042 &, 020 &, 138 &, 782 &, 884 & 1,707 & 1,800 & 2,082 & 2,442 & 2,442 & 2,884 \\
3:PT &, 047 &, 042 &, 000 &, 071 &, 162 &, 530 &, 641 & 1,503 & 1,600 & 1,891 & 2,261 & 2,261 & 2,714 \\
4:ES &, 067 &, 020 &, 071 &, 000 &, 056 &, 696 &, 765 & 1,437 & 1,518 & 1,765 & 2,085 & 2,085 & 2,483 \\
5:LT &, 232 &, 138 &, 162 &, 056 &, 000 &, 493 &, 513 &, 959 & 1,022 & 1,217 & 1,478 & 1,478 & 1,811 \\
6:HU &, 885 &, 782 &, 530 &, 696 &, 493 &, 000 &, 014 &, 431 &, 492 &, 681 &, 934 &, 934 & 1,259 \\
7:PL & 1,015 &, 884 &, 641 &, 765 &, 513 &, 014 &, 000 &, 291 &, 340 &, 500 &, 720 &, 720 & 1,008 \\
8:NO & 1,966 & 1,707 & 1,503 & 1,437 &, 959 &, 431 &, 291 &, 000 &, 002 &, 028 &, 096 &, 096 &, 216 \\
9:RO & 2,071 & 1,800 & 1,600 & 1,518 & 1,022 &, 492 &, 340 &, 002 &, 000 &, 015 &, 070 &, 070 &, 177 \\
10:EU & 2,382 & 2,082 & 1,891 & 1,765 & 1,217 &, 681 &, 500 &, 028 &, 015 &, 000 &, 020 &, 020 &, 088 \\
11:NL & 2,775 & 2,442 & 2,261 & 2,085 & 1,478 &, 934 &, 720 &, 096 &, 070 &, 020 &, 000 &, 000 &, 024 \\
12:IT & 2,775 & 2,442 & 2,261 & 2,085 & 1,478 &, 934 &, 720 &, 096 &, 070 &, 020 &, 000 &, 000 &, 024 \\
13:AT & 3,254 & 2,884 & 2,714 & 2,483 & 1,811 & 1,259 & 1,008 &, 216 &, 177 &, 088 &, 024 &, 024 &, 000 \\
\hline
\end{tabular}

This is a dissimilarity matrix

\section{Average Linkage (Between Groups)}

Agglomeration Schedule

\begin{tabular}{|c|c|c|c|c|c|c|}
\hline \multirow[t]{2}{*}{ Stage } & \multicolumn{2}{|c|}{ Cluster Combined } & \multirow[t]{2}{*}{ Coefficients } & \multicolumn{2}{|c|}{ Stage Cluster First Appears } & \multirow[t]{2}{*}{ Next Stage } \\
\hline & Cluster 1 & Cluster 2 & & Cluster 1 & Cluster 2 & \\
\hline 1 & 11 & 12 & ,000 & 0 & 0 & 5 \\
\hline 2 & 8 & 9 &, 002 & 0 & 0 & 9 \\
\hline 3 & 6 & 7 & ,014 & 0 & 0 & 11 \\
\hline 4 & 1 & 2 &, 015 & 0 & 0 & 6 \\
\hline 5 & 10 & 11 &, 020 & 0 & 1 & 7 \\
\hline 6 & 1 & 4 & ,044 & 4 & 0 & 8 \\
\hline 7 & 10 & 13 & ,046 & 5 & 0 & 9 \\
\hline 8 & 1 & 3 & ,053 & 6 & 0 & 10 \\
\hline 9 & 8 & 10 & ,096 & 2 & 7 & 11 \\
\hline 10 & 1 & 5 & , 147 & 8 & 0 & 12 \\
\hline 11 & 6 & 8 & 692 & 3 & 9 & 12 \\
\hline 12 & 1 & 6 & 1,684 & 10 & 11 & 0 \\
\hline
\end{tabular}




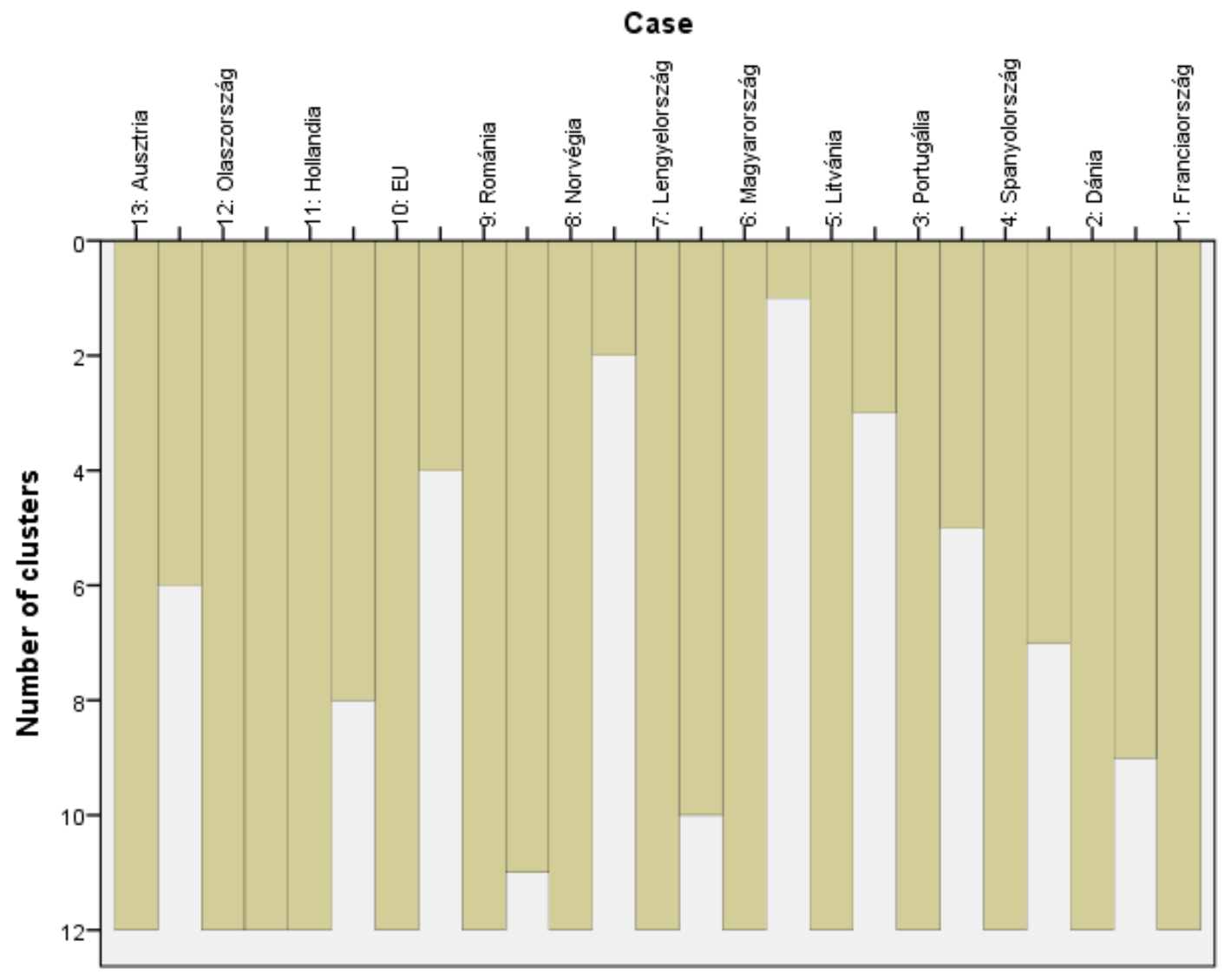

